\title{
Avaliação de um recurso técnico na aprendizagem de conceitos por crianças cegas: um estudo exploratório.
}

Dissertação apresentada ao Instituto de Psicologia da Universidade de São Paulo como parte dos requisitos para a obtenção do título de Mestre em Psicologia.

Área de concentração: Psicologia Escolar e do Desenvolvimento Humano.

Orientador: Prof. Associado Dr. José Fernando Bitencourt Lomônaco.

São Paulo 
AUTORIZO A REPRODUÇÃO E DIVULGAÇÃO TOTAL OU PARCIAL DESTE TRABALHO, POR QUALQUER MEIO CONVENCIONAL OU ELETRÔNICO, PARA FINS DE ESTUDO E PESQUISA, DESDE QUE CITADA A FONTE.

Catalogação na publicação

Biblioteca Dante Moreira Leite

Instituto de Psicologia da Universidade de São Paulo

Cabral, Caio Parada.

Avaliação de um recurso técnico na aprendizagem de conceitos por crianças cegas: um estudo exploratório / Caio Parada Cabral; orientador José Fernando Bitencourt Lomônaco. -- São Paulo, 2011.

$243 \mathrm{f}$.

Dissertação (Mestrado - Programa de Pós-Graduação em Psicologia. Área de Concentração: Psicologia Escolar e do Desenvolvimento Humano) - Instituto de Psicologia da Universidade de São Paulo.

1. Deficiente visual 2. Formação de conceitos 3. Desenhos em relevo I. Título.

BF727.B4 
Nome: Caio Parada Cabral

Título: Avaliação de um recurso técnico na aprendizagem de conceitos por crianças cegas: um estudo exploratório.

Dissertação apresentada ao Instituto de Psicologia da Universidade de São Paulo para obtenção do título de Mestre em Psicologia.

Área de concentração: Psicologia Escolar e do Desenvolvimento Humano.

Aprovado em: de de

\section{Banca Examinadora}

Prof. Dr.

Instituição: Assinatura:

Prof. Dr.

Instituição: Assinatura:

Prof. Dr.

Instituição: Assinatura: 
À minha esposa Fernanda, de quem recebi o presente mais caro: compartilhar sua vida comigo.

Aos meus pais, Hugo e Débora, que me ensinaram a brincar de ser cientista. Aos meus avós, que alimentaram docemente a minha curiosidade e imaginação. 


\section{AGRADECIMENTOS}

Meus mais sinceros agradecimentos para:

Prof. Dr. José Fernando Bitencourt Lomônaco, por seu acompanhamento preciso durante todo o processo que resultou neste trabalho, pelos ensinamentos transmitidos e pelas conversas acompanhadas de café.

Prof $^{a} \operatorname{Dr}^{\mathrm{a}}$ Maria Lucia Toledo Moraes Amiralian e $\operatorname{Prof}^{\mathrm{a}} \operatorname{Dr}^{\mathrm{a}}$ Marie Claire Sekkel, pelas valiosas contribuições prestadas no exame de qualificação.

Professores com que tive aula no programa de pós-graduação, por todo o conhecimento compartilhado.

Querida irmã Camila, por todo o apoio que foi indispensável para que eu chegasse até aqui.

Queridos amigos Theo, Fernanda, Natália e Arthur, por sua amizade sincera e revitalizante.

Companheiro de longa data Jaime, por todo apoio e pela minuciosa tradução do resumo deste trabalho para a língua inglesa.

Inseparáveis companheiros Doug e Duda, pela amizade fiel e companheira.

Todos os meus familiares que, de uma forma ou de outra, contribuíram para este momento.

Professora e grande amiga Renata Machado, pelo constante incentivo à pesquisa.

Querido amigo Danilo, pelo apoio e ajuda nos momentos mais difíceis pelos quais passei nestes últimos três anos.

Prof $^{a}$ Tânia Regina, pelo esforço empenhado na contribuição desta pesquisa.

Todos os alunos que participaram deste trabalho.

Fernanda, Amélia e Danilo, pela ajuda na avaliação dos dados deste trabalho.

Nando, pela contribuição no tratamento gráfico dos modelos de desenhos utilizados.

E, finalmente, para minha esposa Fernanda Cabral por estar ao meu lado nesta e em tantas outras jornadas. 


\section{RESUMO}

CABRAL, C. P. (2011). Avaliação de um recurso técnico na aprendizagem de conceitos por crianças cegas: um estudo exploratório. Dissertação de Mestrado, Instituto de Psicologia, Universidade de São Paulo, São Paulo.

O objetivo desta pesquisa foi investigar os efeitos da utilização de um recurso técnico, o desenho em alto relevo, no processo de aquisição e reconhecimento de conceitos por crianças com deficiência visual em dois aspectos: (a) verificar a efetividade do recurso técnico em transformar estímulos não acessíveis aos sentidos das pessoas cegas em acessíveis; e (b) identificar mudanças significativas na percepção dos atributos definidores destes conceitos após treinamento com desenhos em relevo. Participaram da pesquisa cinco crianças e adolescentes com deficiência visual, portadores de cegueira congênita e adquirida, com idades entre 9 e 17 anos, matriculados em uma sala de recursos de uma escola estadual da cidade de São Paulo. Foram escolhidos para a investigação oito conceitos espontâneos que, apesar de serem conhecidos pelos sujeitos, não são de fácil apreensão para a pessoa cega. $O$ procedimento foi realizado em três etapas: pré-teste, treinamento e pós-teste. No pré-teste o pesquisador realizou uma entrevista de aproximadamente 30 minutos com cada sujeito, na qual solicitou aos sujeitos que, primeiramente, definissem verbalmente os conceitos apresentados e, após as definições verbais, que desenhassem os exemplos dos conceitos. Na etapa de treinamento foram realizadas três sessões individuais com cada sujeito, nas quais o pesquisador apresentou modelos de desenhos em relevo referentes aos conceitos investigados anteriormente e os orientou na produção de desenhos que pudessem representar suas ideias a respeito destes conceitos. A etapa do pós-teste seguiu o mesmo procedimento do pré-teste. Solicitou-se ao sujeito definições verbais e desenhos de exemplos dos oito conceitos pesquisados. Todas as sessões foram realizadas na sala de recursos de uma escola estadual, durante o horário letivo. O material utilizado para a produção dos desenhos em relevo foi uma prancha de madeira revestida com uma tela de fios entrelaçados e uma caneta, sem tinta, com ponta de metal. As entrevistas foram registradas por um gravador eletrônico de áudio e filmadas com câmera digital, mediante autorização dos responsáveis legais dos sujeitos. As respostas verbais foram transcritas e os desenhos copiados digitalmente. O material foi organizado de acordo com a lista de conceitos e avaliado por três juízes convidados, que atribuíram notas de 1 a 5 às definições verbais e aos desenhos das etapas de pré e pós-teste. Os resultados foram analisados comparando-se as médias aritméticas atribuídas pelos juízes ao material produzido pelos sujeitos nas etapas de testagem. Observaram-se as mudanças na qualidade das definições verbais e dos desenhos após o período de treinamento. Em função do reduzido número de sujeitos de pesquisa, os dados foram discutidos com considerando as mudanças que cada sujeito apresentou em relação a si mesmo. Os resultados demonstraram que os sujeitos apresentaram melhorias mais significativas nas definições verbais dos conceitos do que nas representações gráficas. Assim sendo, é sugerido que a utilização dos desenhos em relevo pareceu favorecer mais o desenvolvimento da linguagem oral do que à expressão gráfica em si.

Palavras-chave: deficiência visual, conceitos, desenhos em relevo. 


\begin{abstract}
CABRAL, C. P. (2011). Evaluation of a technical resource in blind children's concept learning: an exploratory study. Dissertação de Mestrado, Instituto de Psicologia, Universidade de São Paulo, São Paulo.
\end{abstract}

The objective of this research was to investigate the effects of using a technical resource, namely embossed drawing or engraving, in the process of acquisition and recognition of concepts by visually impaired children. In this process, there are two main points: (a) verifying the effectiveness of a technical resource in transforming stimuli that are inaccessible to the senses of blind people into accessible ones; and (b) identifying significant changes in the perception of the defining attributes of such concepts after training with embossed drawings or engraving. This work had five research subjects. There were five visually impaired children and adolescents, with congenital or acquired blindness, aged 9 to 17, and enrolled in a school with a resource classroom in São Paulo city. Eight spontaneous concepts were chosen for investigation, taking into consideration that even though such concepts are known by the subjects, they are not readily comprehensible to the blind. The experimental design consisted of three phases: pre-test, training, and post-test. In the pre-test, the researcher interviewed each subject for approximately 30 minutes, asking them to first define the concepts presented verbally, and after such verbal definitions, to draw examples of the concepts. In the training stage, there were three individual sessions with each subject, in which the researcher presented models of engravings and embossed drawings referring to the concepts previously investigated, and guided them in the production of drawings that could represent their ideas on the concepts. In the post-test stage, it was carried out the same procedure as the pre-test. Subjects were asked to provide verbal definitions and drawings of examples of the eight concepts that were studied previously. All sessions were held in the resource room of the state school during school hours. The materials used for producing embossed drawings were a wooden pad covered with a fabric screen made of interwoven threads, and an inkless pen with a metal tip. With the consent of the children's custodian, the interviews were recorded by an electronic audio device and filmed with a digital camera. Verbal responses were transcribed and drawings were scanned digitally. Materials were organized according to the list of concepts, and they were evaluated by three invited judges, who graded the verbal definitions and drawings gathered in pre- and post-test phases from 1 to 5 . The results were analyzed by the arithmetic averages of the grades assigned to the materials produced in the first testing stage compared to the second testing stage. It were observed changes in the quality of verbal definitions and drawings after the training period. The low number of subjects does not allow generalizations, so that data was discussed considering the changes that each subject presented in relation to himself. The results demonstrate that subjects showed greater improvement in verbal definitions of concepts than in graphical representations. Therefore, we consider that the use of embossed drawings and engravings are of greater use to development of spoken language than to graphic expression itself.

Key-words: visual disabilities, concepts, embossed drawings (engravings) 


\section{LISTA DE FIGURAS}

Figura 1 - Exemplo de tabela de avaliação utilizada pelos juízes

Figura 2 - Comparativo entre as médias gerais das definições

verbais dos conceitos

Figura 3 - Comparativo entre as médias gerais dos desenhos

dos conceitos

Figura 4 - Comparativo entre as médias gerais das definições

verbais dos sujeitos 82

Figura 5 - Comparativo entre as médias gerais dos desenhos

dos sujeitos

Figura 6 - Gráfico comparativo entre definições verbais e desenhos dos conceitos

Figura 7 - Gráfico comparativo entre definições verbais e desenhos dos sujeitos. 


\section{LISTA DE TABELAS}

Tabela 1 - Conceito "Girafa": avaliação da definição e do desenho pelos juízes

Tabela 2 - Conceito "Nuvem": avaliação da definição e do desenho pelos

juízes

Tabela 3 - Conceito "Montanha": avaliação da definição e do desenho pelos

juízes

Tabela 4 - Conceito “Árvore”: avaliação da definição e do desenho pelos

juízes

Tabela 5 - Conceito “Trem”: avaliação da definição e do desenho pelos

juízes

Tabela 6 - Conceito "Leão": avaliação da definição e do desenho pelos

juízes

Tabela 7 - Conceito "Prédio": avaliação da definição e do desenho pelos

juízes

Tabela 8 - Conceito "Ilha": avaliação da definição e do desenho pelos

juízes

Tabela 9 - Avaliação de desempenho do sujeito de pesquisa

Vítor.

Tabela 10 - Avaliação de desempenho do sujeito de pesquisa

Bruno

Tabela 11 - Avaliação de desempenho do sujeito de pesquisa

Daniela

Tabela 12 - Avaliação de desempenho do sujeito de pesquisa

Rogério 80 
Tabela 13 - Avaliação de desempenho do sujeito de pesquisa

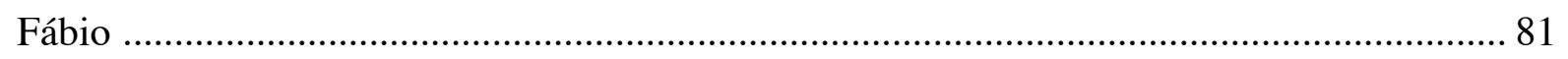


APRESENTAÇÃO

\section{A PESSOA COM DEFICIÊNCIA VISUAL: CARACTERIZAÇÃO,} PRECONCEITOS E INCLUSÃO ………………………………………………………16

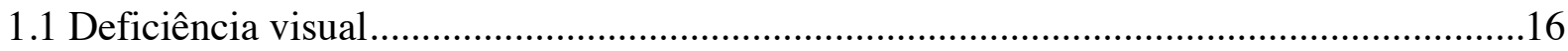

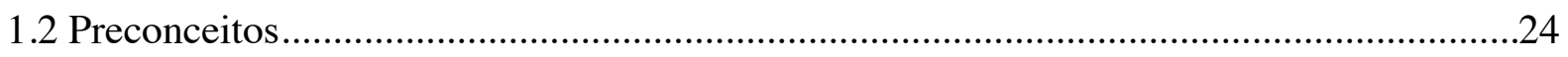

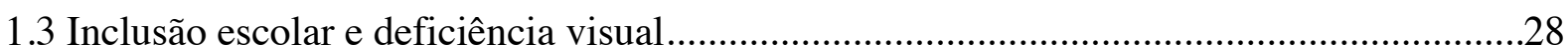

2 FORMAÇÃO DE CONCEITOS E DEFICIÊNCIA VISUAL ………………………….....36

2.1 Dificuldades na definição de conceito...........................................................................38

2.2 Teorias ou visões sobre a formação de conceitos............................................................40

2.3 O uso de recursos tecnológicos para aprendizagem em crianças cegas

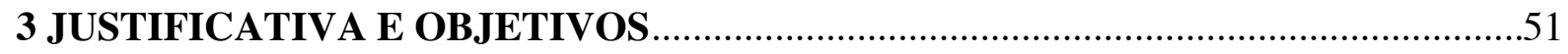

3.1 Justificativa

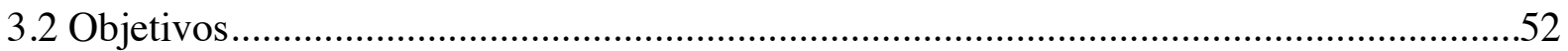

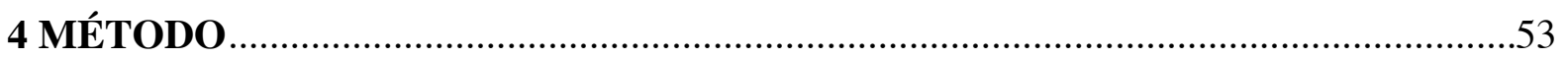

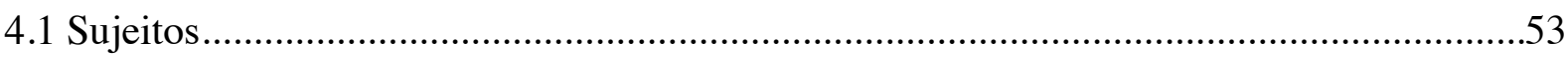

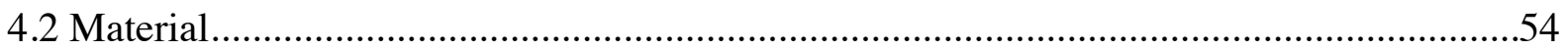

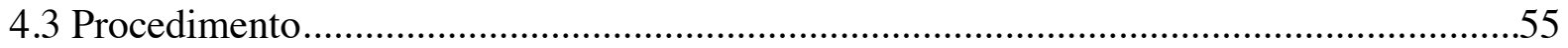

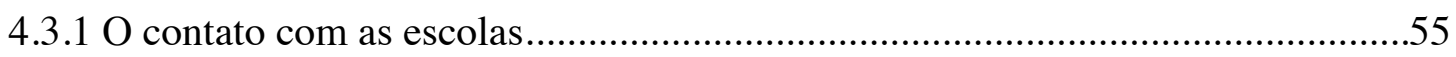

4.3.2 Seleção dos alunos participantes......................................................................57

4.3.3 Consentimento .........................................................................................58 


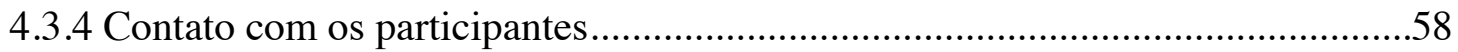

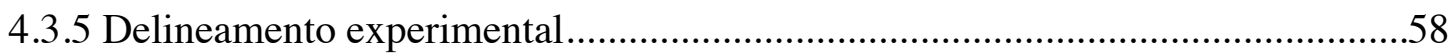

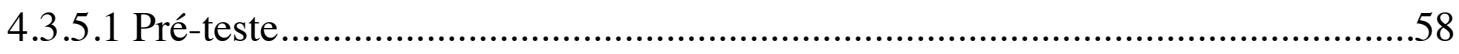

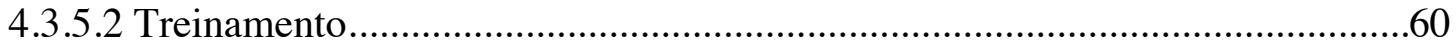

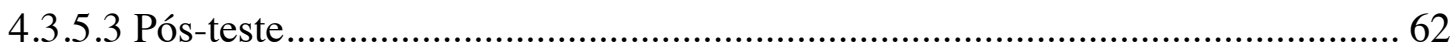

5 RESULTADOS

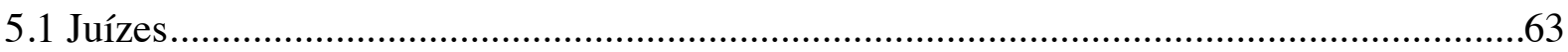

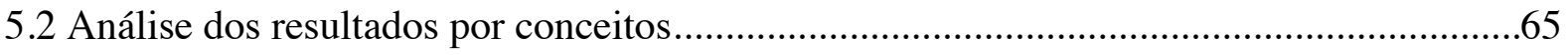

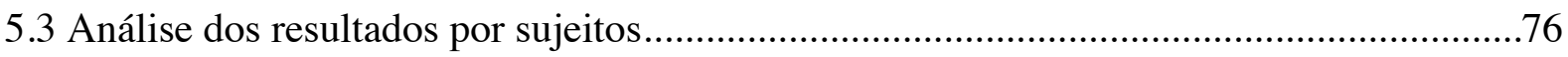

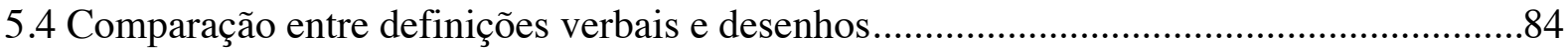

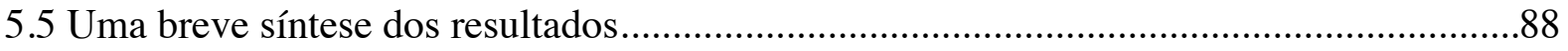

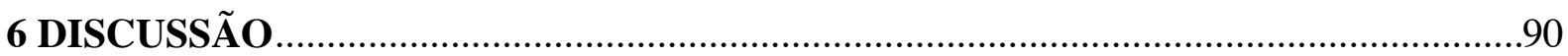

REFERENCIAS

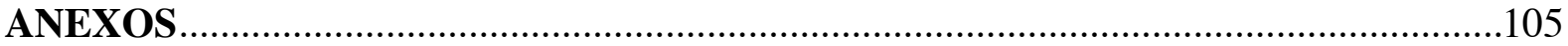




\section{APRESENTAÇÃO}

A ideia deste trabalho surgiu em meados de 2006, quando cursei a disciplina Conceitos: visões psicológicas, ministrada pelo Prof. Dr. José Fernando B. Lomônaco, no Instituto de Psicologia da Universidade de São Paulo.

$\mathrm{Na}$ época, eu trabalhava com Educação Especial, em uma escola particular que atendia, prioritariamente, crianças e adolescentes com paralisia cerebral. Minha atuação era um misto de professor e terapeuta de reabilitação, pois além de trabalhar com o ensino de conhecimentos gerais em língua portuguesa, matemática, geografia, etc., também atentava para rotina de alimentação (que exige uma série de conhecimentos técnicos, para atender as pessoas com paralisia cerebral adequadamente), comunicação, atividades físicas adaptadas para as condições físicas dos alunos e outras tantas práticas.

Antes de atuar como professor desta escola, havia atuado como estagiário em outras instituições especializadas em públicos diferenciados, como pessoas com Síndrome de Down, Autismo, dentre outros.

Concluí o curso de graduação em Psicologia, pela Universidade Presbiteriana Mackenzie, onde tive a oportunidade de iniciar os estágios na área de educação especial, bem como estudar temas relacionados a pessoas com deficiências.

Como psicólogo, sempre mantive interesse em dois aspectos relativos à Educação Especial: inclusão social e aprendizagem. O primeiro porque me chama atenção a maneira pela qual os diferentes segmentos da sociedade relacionam-se com a questão da diferença e como criam mecanismos de segregação. Neste ponto, ter atuado em instituições especializadas ensinou-me muito sobre como estes espaços podem ser segregadores, mas, muitas vezes parecem ser os únicos capazes de dar conta do atendimento às pessoas com deficiências ou distúrbios do desenvolvimento, principalmente aquelas mais comprometidas cognitivamente. No tocante à aprendizagem, interesso-me pelas possibilidades que podem ser encontradas e trabalhadas para que pessoas com deficiências executem tarefas que ao olhar de um leigo, ou de um profissional inexperiente, poderiam parecer impossíveis.

Sendo assim, encontrei na disciplina do Prof. Fernando uma rica fonte de estudos sobre a aprendizagem, que influenciou diretamente a minha maneira de pensar a Educação 
Especial. O estudo de conceitos possibilitou muitas reflexões sobre as particularidades da aprendizagem de pessoas com condições físicas ou cognitivas específicas.

Como trabalho final da disciplina, realizamos um estudo exploratório sobre a aprendizagem de conceitos básicos por crianças com Síndrome de Down. A experiência deste trabalho foi inspiradora para a elaboração de um projeto de mestrado.

Ainda em 2006 comecei a trabalhar em uma organização não-governamental, na área de educação inclusiva. O meu trabalho consistia em prestar assistência especializada para a rede municipal de ensino de uma cidade da grande São Paulo. Foi neste período que tomei contato com a área de deficiência visual. Apesar de não ser especialista na área, organizava e acompanhava palestras e cursos ministrados por especialistas para professores da rede.

Ao começar a trabalhar na ideia do projeto de mestrado, conheci a dissertação de mestrado de Nunes (2004), intitulada: "Desenvolvimento de conceitos em cegos congênitos: caminhos de aquisição do conhecimento", orientada pelo Prof. Fernando. A pesquisa desenvolvida pela autora foi o ponto de partida para que eu começasse a pensar em qualquer coisa que relacionasse a aprendizagem de conceitos com a deficiência visual. A autora demonstrou como crianças cegas congênitas podem adquirir conceitos de maneira geral, inclusive aqueles que não são diretamente acessíveis aos sentidos do cego.

Uma vez que a dissertação de Nunes demonstrou como pessoas cegas congênitas adquirem conceitos, pensei que uma maneira de seguir os passos desta pesquisa seria estudar como os "caminhos de aquisição" poderiam ser facilitados pelo uso de recursos tecnológicos, que comumente fazem parte dos trabalhos práticos de reabilitação e acessibilidade.

Dentre o vasto campo da tecnologia para a reabilitação e educação de pessoas cegas, decidi direcionar a atenção para aqueles que poderiam atingir uma questão central abordada por Nunes: conceitos que não são tateáveis, como arco-íris, por exemplo são aprendidos por meio da linguagem, ou seja, pela percepção visual de uma segunda pessoa, que traduz para o plano da linguagem aquilo que foi capturado pela visão. Mesmo sabendo que este processo é eficaz para a aquisição do conceito, faz sentido questionar se não poderíamos traduzir estas informações visuais, ou melhor, estas imagens, para um plano mais acessível ao cego por outros sentidos, além da linguagem. 
Este trabalho tem o objetivo de investigar o processo de formação de conceitos por crianças cegas por meio de desenhos feitos especificamente para cegos. Os estudos realizados por Ormelezi (2000), Nunes (2004) e Nunes e Lomônaco (2008), demonstram que os cegos formam conceitos, mesmo aqueles conceitos em que a imagem é fundamental para sua formação nas pessoas que possuem visão. O conceito de lua é um exemplo que demanda a percepção da imagem para sua formação, mas a pessoa cega é capaz de formar o conceito a partir da descrição feita por uma outra pessoa. Portanto, a linguagem é fundamental para que o cego possa formular ideias a respeito daquilo que é tangível (Ormelezi, 2000). Porém, cabe perguntar se, também com o uso da tecnologia ou de outros recursos, não podemos tornar perceptíveis aos sentidos dos cegos coisas que ainda não são?

Em sua dissertação de mestrado, Ormelezi (2000) afirma que, a partir do diálogo com uma pessoa que enxerga (vidente), o sujeito cego pode formar representações mentais daquilo que não pode ser captado diretamente por seus sentidos, ou seja, a pessoa cega forma conceitos. Mas, se estes conceitos não são representados por imagens, que forma eles têm? Como o aparelho cognitivo da pessoa cega reverbera a informação linguística em conceitos? Este trabalho propõe-se a explorar a formação de conceitos por crianças cegas a partir destas questões. 


\section{CAPÍTULO 1}

\section{A PESSOA COM DEFICIÊNCIA VISUAL: CARACTERIZAÇÃO, PRECONCEITOS E INCLUSÃO.}

\subsection{Deficiência visual}

Nos dias atuais grande parte das informações disponíveis no ambiente são de natureza visual. Embora todo tipo de informação sensorial seja importante, em seu atual estágio evolutivo a espécie humana utiliza predominantemente a visão para perceber os estímulos do ambiente. Um indício disto é que, dentre pessoas que enxergam, uma parte substancial do córtex é destinado ao processamento visual. Esta supremacia da visão sobre os demais sentidos não é casual, uma vez que, por meio dela, podemos ter acesso aos estímulos do ambiente à distância, o que nos permite avaliar uma situação de forma mais segura, como notar um carro que vem pela rua ou, então, captar elementos úteis para planejar uma ação, como "calcular" mentalmente o tempo que vou levar de um ponto A para um ponto B. Situações como esta, em que utilizamos a visão para avaliar o ambiente, são frequentes, e colaboraram para o desenvolvimento de sinapses envolvidas no processamento visual. Caso os estímulos auditivos, táteis ou somestésicos demandassem mais atenção do nosso sistema cognitivo, certamente desenvolveríamos áreas corticais mais extensas para o processamento destes estímulos (Gazzaniga, Ivry, \& Mangnun, 2006).

Ao longo do desenvolvimento humano, a importância dos estímulos visuais pode variar muito. A capacidade de um recém nascido enxergar a distância é baixa, com acuidade visual em torno de 20/400. Com 1 mês de idade, o bebê ainda não consegue manter a atenção visual em um mesmo objeto pelo tempo necessário para uma análise eficiente do mesmo (Belsky, 2010). No curto período em que mantém a atenção no objeto, o bebê não se atém às partes centrais, mas observa as partes periféricas. Ao olhar para um rosto, por exemplo, o bebê focaliza a região dos cabelos e das orelhas, ao invés de olhos e boca. É aos 3 meses que ele desenvolve melhor a percepção dos aspectos mais relevantes dos objetos e, consequentemente, consegue acompanhar os objetos em movimento por mais tempo. Neste período o bebê também melhora a sua percepção de cores e a visão binocular, fundamental para a percepção de profundidade (Berger, 2003). Esta capacidade perceptiva (enxergar em três dimensões) impulsiona o desenvolvimento de uma série de outras habilidades, como o 
interesse em explorar o ambiente com as mãos, engatinhar, etc. Durante este período o córtex visual se desenvolve rapidamente e, com aproximadamente 1 ano de idade, a criança possui a mesma capacidade visual de um sujeito adulto.

Palácios (2004) ressalta que o desenvolvimento humano deve ser estudado a partir de três aspetos fundamentais: normativo (ou seminormativo), cultural e idiossincrático. $\mathrm{O}$ primeiro diz respeito às mudanças no desenvolvimento que são comuns a todos os seres humanos, em uma determinada cultura (seminormativo, pois pode corresponder a uma população significativa, mas não à totalidade) e em um determinado momento histórico. Sendo assim, pode-se entender que o uso da visão como principal mecanismo para o processamento das informações na infância é um fenômeno normativo.

Embora o estudo normativo favoreça o estabelecimento de parâmetros para o desenvolvimento humano, o referido autor ressalta que, ao longo deste processo, os indivíduos passam por experiências únicas que podem ter impacto decisivo no seu desenvolvimento. Principalmente a partir da adolescência, as experiências individuais dificultam o estabelecimento de uma psicologia do desenvolvimento mais normativa e, sobretudo na idade adulta e na velhice, os acontecimentos particulares na vida de cada sujeito desenham uma trajetória que dificilmente pode ser generalizada para todos os sujeitos.

O que se pretende demonstrar com isto é que, embora possamos admitir que a visão ocupe um lugar central no desenvolvimento cognitivo, como defendem Toledo et. al (2010) em seu artigo sobre a importância da detecção precoce da deficiência visual e suas relações com o desempenho escolar, e Amiralian (1997), quando se refere aos estudos piagetianos sobre deficiência visual; a perda da visão em diferentes momentos do desenvolvimento (infância, idade adulta ou velhice) e em diferentes culturas certamente leva o sujeito a desenvolver habilidades cognitivas e motoras específicas, de acordo com sua condição.

Autores como Piaget, Freud e Vygotsky ressaltam a importância da visão nas primeiras etapas do desenvolvimento, em que a criança constrói representações mentais dos objetos presentes no mundo. Para os psicólogos desenvolvimentistas, a construção de representações mentais - conceitos - na infância depende tanto das experiências anteriores (motoras e sensoriais) como das potencialidades herdadas geneticamente pela espécie, que proporcionam à criança a capacidade de atribuir significado às coisas com as quais interage (Palácios, 2004). Neste sentido, a visão ocupa o importante papel de integrar as informações, 
uma vez que a percepção visual impele a criança a explorar seu meio. Por exemplo, ao ouvir um ruído, a criança utiliza a visão para encontrar a fonte do som. Por meio da visão, captamos milhares de informações num curtíssimo período de tempo. Assim sendo, muitos de nossos conceitos devem refletir fortemente as informações visuais.

Cabem, então, algumas perguntas: Como ocorre o processo de formação de conceitos naquelas pessoas que não dispõem de pistas visuais? De que maneira as pessoas cegas captam e organizam informações para formar seus conceitos? Quais recursos tecnológicos poderiam contribuir para a melhoria destes processos? Estas são algumas questões que serão consideradas no presente trabalho.

Amiralian (1997), explica que a ausência da visão no início da vida traz consequências importantes para o desenvolvimento da personalidade e para o desenvolvimento cognitivo, uma vez que a ausência da visão precisa ser compensada por outras vias sensoriais, como o tato e a audição. A autora faz uma revisão dos estudos piagetianos e psicanalíticos sobre como a cegueira participa do desenvolvimento global da criança.

De acordo com o referencial piagetiano, as crianças cegas fazem uso dos seus outros recursos sensoriais, de forma que o resultado final do desenvolvimento cognitivo é praticamente o mesmo ao das crianças videntes, embora deva-se considerar que o uso destes outros sentidos confere ao cego uma construção da realidade particular. Um exemplo disto, é que, ao basear-se no som e no tato, a representação dos objetos pela criança torna-se estática, pois falta-lhe a informação visual do movimento do objeto pelo espaço, sem a influência direta do sujeito que o movimenta.

Do ponto de vista psicanalítico, são diversas os significados que a cegueira assume para o sujeito. Segundo Blank (1958, citado por Amiralian, 1997) a cegueira congênita não causa, por si mesma, distúrbios de personalidade. No entanto, a representação que a cegueira tem para os pais da criança interfere diretamente nas formas de interação com o bebê, momento importante para a formação da personalidade. As principais distorções que ocorrem - em relação à pessoa cega - são a superproteção, na qual espera-se que o cego seja muito dependente e submisso, e a crença de que o cego possui "superpoderes", pois teria os outros sentidos muito mais desenvolvidos do que os videntes.

Para Blank, quando a cegueira é adquirida subitamente, quebram-se os padrões de relação com o ambiente e consigo mesmo que já estavam estabelecidos. Sendo assim, cabe ao 
sujeito reconstruir sua maneira de interagir com o ambiente, assim como de integrar sua nova condição à identidade. Em sujeitos psicologicamente saudáveis, o processo de elaboração da perda pode ser dividido em dois estágios. O primeiro é o do choque imediato, que dura de 2 a 7 dias, no qual o sujeito fica praticamente atônito, sente-se despersonalizado e deprimido. Quando se sente deprimido, a pessoa está em contato com os afetos envolvidos na perda da visão e, aos poucos, começa a refazer seu Eu e chega a uma nova imagem de si. Esta recuperação gradativa caracteriza o segundo estágio, o definitivo.

Caso a cegueira ocorra de maneira progressiva, o sujeito não passa pelo primeiro estágio, mas a elaboração das mudanças decorrentes da perda é fundamental para o desenvolvimento saudável do indivíduo.

Todavia, mesmo que as alterações na visão não representem impedimentos às funções cognitivas ou à formação da personalidade, o sujeito poderá vivenciar limitações, decorrentes da relação entre a falta de visão e o contexto sociocultural do qual faz parte. Neste ponto os recursos tecnológicos são importantes, por permitir à pessoa cega realizar tarefas comuns a todos os membros da coletividade, como ler e escrever, utilizar um computador, utilizar o transporte público, etc.

Assim, pode-se questionar o quanto a ausência de recursos tecnológicos prejudica a interação da pessoa cega em um ambiente, já que elas mostram-se capazes de circular por espaços conhecidos e desconhecidos com o uso dos sentidos que possui e também pelo uso da linguagem oral. Assim, a ausência da tecnologia não representaria um grande impedimento para que se possa desenvolver alguma atividade. Cabe, porém, considerar outras situações mais complexas como, por exemplo, um posto de trabalho. Atualmente, muitas ocupações no mercado de trabalho (e o mesmo aplica-se às atividades acadêmicas) envolvem o uso do computador para a execução de tarefas. Para que a pessoa cega possa desempenhar suas funções com este recurso, são necessárias certas adaptações na máquina e um treinamento específico de quem irá utilizá-la. Tal providência é fundamental, mas pode ser comprometida de várias maneiras: desconhecimento das adaptações para o computador pelo empregador, ausência das adaptações, falta de treinamento para utilização correta do instrumento, falta de recursos financeiros para aquisição da máquina ou da adaptação, ineficácia das adaptações existentes para o tipo de tarefa exigida, etc. Todas estas situações implicam em barreiras para os sujeitos e, quando isto ocorre, experimentam limitações ligadas à ausência de visão (cegueira). 
As barreiras que limitam a participação social da pessoa cega assemelham-se àquelas experimentadas por todas as pessoas que possuem algum tipo de deficiências: arquitetônicas, de acesso a educação e preconceito. A fim de lidar com as estas questões, diversos setores da sociedade elaboram e aplicam medidas de intervenção. Tais medidas podem ser mais planejadas e estudadas, como nas políticas públicas e na academia; ou então são construídas lentamente ao longo do tempo e espontaneamente, como as formas mais ou menos preconceituosas de lidar com as pessoas com deficiência.

Ao longo da história a sociedade modificou suas formas de interação com as pessoas com deficiência. Na Grécia Antiga e no Império Romano a eliminação de crianças com deficiência era algo aceito e até mesmo comum (Namo, 2007). Com o advento do cristianismo e a consequente aceitação dos princípios da virtude, da caridade e da valorização da vida de todas as pessoas, as pessoas com deficiência passaram a ser vistas como objetos de caridade e benevolência. Neste período estas pessoas viviam da caridade ou trabalhavam por troca de indulgências. Com o desenvolvimento da medicina, da tecnologia e das ciências em geral, que se deu a partir do Renascimento, entendeu-se que a problemática das pessoas com deficiência deveria ser tratado pela medicina. Assim, compreender os processos que originam as deficiências, bem como as medidas cabíveis para seu tratamento e para redução do impacto das mesmas no desenvolvimento do sujeito (reabilitação), foram os principais objetivos do relacionar-se com as pessoas com deficiência, nesta época.

A partir de então, o desenvolvimento científico na área da saúde e da tecnologia cresceu enormemente, o que levou o percurso de vida da pessoa com deficiência ser controlado principalmente pela medicina e pelas instituições especializadas. Embora estes setores continuem a exercer um papel importante, a condução das discussões sobre os assuntos que envolvem as pessoas com deficiência tem a participação ativa daqueles que representam este grupo, bem como de todos aqueles envolvidos diretamente com tais questões.

Não é o objetivo deste trabalho revisar detalhadamente o histórico da relação entre deficiência e sociedade $^{1}$, mas contextualizar a deficiência visual como inserida em uma categoria mais abrangente, da qual compartilha uma série de questões. Uma vez abordados os

\footnotetext{
${ }^{1}$ Para maior aprofundamento neste tópico, ver os trabalhos de Amiralian (1997) e Nunes (2004).
} 
temas comuns a todas as deficiências, podemos discutir a especificidade da deficiência visual de forma mais eficaz.

Como aponta Amiralian at al. (2000), a busca de uma classificação adequada dos estados de saúde e das condições das funções do corpo é bastante antiga, mas é apenas em 1976 que o termo deficiência é cunhado na área da saúde, em caráter internacional, e traduzido para o português em 1980. De acordo com esta autora, o conceito de deficiência tem sido questionado pelos estudiosos da área, mas há um certo consenso em adotar a definição da Organização Mundial da Saúde (OMS) como referencial, qual seja:

Perda ou anormalidade de estrutura ou função psicológica, fisiológica ou anatômica, temporária ou permanente. Incluem-se nessas a ocorrência de uma anomalia, defeito ou perda de um membro, órgão, tecido ou qualquer outra estrutura do corpo, inclusive das funções mentais. Representa a exteriorização de um estado patológico, refletindo um distúrbio orgânico, uma perturbação no órgão. (World Health Organization, 1993, citado por Amiralian et al, 2000, p. 98)

Nota-se que o conceito de deficiência enunciado acima é caracterizado pela descrição de eventuais mudanças no corpo humano em relação ao padrão esperado e está restrito apenas às condições corporais individuais; não há menção à relação deste corpo com o meio físico ou social, não são mencionadas barreiras. Considerando que esta relação é importante, a OMS formulou os conceitos de incapacidade e desvantagem, que devem ser associados ao conceito de deficiência. Neste sentido, a incapacidade refere-se às restrições experimentadas pelo sujeito que estão diretamente relacionadas à sua deficiência, como a impossibilidade de enxergar para a pessoa cega ou a impossibilidade de andar para a pessoa paraplégica. A desvantagem é caracterizada pelas situações sociais em que o sujeito é impedido ou prejudicado em sua participação social pela configuração de um ambiente desfavorável à sua condição, como a falta de um computador com adaptações para a pessoa cega em um posto de trabalho. Nota-se que, nesta situação, o sujeito poderia perfeitamente realizar a atividade, mas o contexto o impede e o coloca em desvantagem em relação àqueles que não possuem a deficiência visual.

A proposição desta tríade de conceitos indica que, para estudar uma condição de deficiência é preciso atentar para outros aspectos além dos físicos e cognitivos, que é importante estudar o contexto social, cultural e econômico no qual o sujeito está inserido. Embora os conceitos de incapacidade e desvantagem tenham sido reformulados pela própria 
$\mathrm{OMS}^{2}$, é importante considerá-los em qualquer estudo relacionado à pessoa com deficiência e será adotado neste trabalho.

No ano de 2006, a ONU promoveu, em sua sede em Nova York, a Convenção sobre os Direitos das Pessoas com Deficiência, na qual estiveram presentes políticos e representantes da sociedade civil de 192 países. Neste importante evento, do qual o Brasil fez parte, discutiu-se, dentre outros assuntos, o conceito de deficiência. Entretanto a discussão percorreu uma caminho um pouco diferente em relação àquela descrita pela OMS. Procurouse compreender a dinâmica entre a deficiência, a pessoa que a possui e o meio físico e social. Sendo assim, o texto da Convenção utiliza o termo pessoa com deficiência, definido já no Artigo $1^{\circ}$ do documento oficial: "Pessoas com deficiência são aquelas que têm impedimentos de natureza física, mental, intelectual ou sensorial, os quais, em interação com diversas barreiras, podem obstruir sua participação plena e efetiva na sociedade com as demais pessoas" (CORDE, 2007, p. 16)

Nesta definição nota-se a preocupação em destacar que os impedimentos para a participação social da pessoa não residem na deficiência em si, mas na interação entre esta condição e as características do meio no qual a pessoa vive. Este conceito complementa a visão predominante na área da saúde e mostra-se interessante para a Psicologia, uma vez que favorece a percepção da pessoa de maneira mais abrangente.

Definidos os conceitos centrais pertencentes a qualquer tipo de deficiência, cabe dissertar sobre o tipo de deficiência abordado no presente estudo: a deficiência visual.

Segundo Espinosa e Ochaíta (2004), a deficiência visual não é propriedade apenas daqueles que vivem na escuridão total, mas também daqueles que possuem limitações visuais que afetam sua aprendizagem. Para a OMS, a deficiência visual é definida como perda de acuidade visual, bilateral, igual ou superior a $70 \%$ no melhor olho e com a melhor correção. A deficiência visual compreende a baixa visão e a cegueira. Na baixa visão a acuidade visual deve ser de $5 \%$ a $30 \%$ no melhor olho com a melhor correção, e o campo visual menor ou igual a $20^{\circ}$, também no melhor olho e com a melhor correção. A cegueira corresponde à

\footnotetext{
${ }^{2}$ Em 2001 é publicada pela OMS a Classificação Internacional de Funcionalidade, Incapacidade e Saúde (CIF), no qual é reforçada a ideia de que o funcionamento da pessoa com deficiência está intrinsecamente ligado ao contexto. Neste texto, o conceito de incapacidade incorpora o sentido da desvantagem e defende-se a ideia de funcionalidade, que analisa a relação entre a deficiência e contexto.
} 
acuidade visual menor ou igual a 5\% e extensão do campo visual menor ou igual a $10^{\circ}$, no melhor olho e com a melhor correção (Resnikoff et. al, 2004).

As principais causas da deficiência visual são erros de refração (miopia, hipermetropia e astigmatismo), catarata, glaucoma, tracoma, retinopatia diabética e problemas relacionados ao envelhecimento (Salomão, Mitsuhiro, \& Belfort Jr., 2009). De acordo com estes autores, a maioria dos casos de deficiência visual poderia ser evitada, mediante políticas eficazes de diagnóstico e prevenção.

Outro dado interessante é que, de acordo com o estudo de Resnikoff et al. (2004), 82\% das pessoas com deficiência visual, em todo o mundo, têm 50 anos ou mais. Sendo a deficiência visual muito mais frequente na idade adulta e velhice do que na infância, torna-se difícil generalizar qualquer padrão de aprendizagem ou da personalidade que se aplique a todos os sujeitos com deficiência visual. Como foi destacado anteriormente, é fundamental compreender a etapa do desenvolvimento em que a perda visual ocorreu.

De acordo com Amiralian (1997) os cegos congênitos são aqueles que perdem a visão antes dos cinco anos de idade, pois geralmente não possuem memória visual. Já os que perdem a visão após esta idade são considerados cegos adventícios ou adquiridos.

No entanto, dois sujeitos com o mesmo diagnóstico de deficiência visual podem construir estratégias cognitivas diferentes para interagir com o ambiente, dependendo do resíduo visual, se possuem percepção de luz e quanto, bem como a maneira como foram estimulados a explorar o ambiente a sua volta. Sendo assim, faz sentido pensar que a conjunção dos fatores ambientais, a maneira como o sujeito vivencia a deficiência e como aprende a criar estratégias cognitivas de ação ou compensação, confere ao sujeito um tipo funcionalidade específico, no qual ele só pode ser comparado consigo mesmo. A OMS (2008 (Nunes, 2010) (Crochík, 2006)) reforça esta condição, ao afirmar que "a funcionalidade de um indivíduo em um domínio específico é uma interação ou relação complexa entre estado ou condição de saúde e fatores ambientais.... Essas interações são específicas e nem sempre ocorrem em uma relação unívoca previsível” (p. 31).

A maneira como a deficiência toma parte no funcionamento do indivíduo deve ser cuidadosamente observada a fim de identificar possíveis necessidades de adaptações para a execução de tarefas de qualquer natureza. Por exemplo, uma pessoa cega com percepção de luz e sombra, pode ter mais facilidade para se locomover nos espaços físicos. Embora esta 
pessoa precise de um treinamento especifico para orientação e mobilidade, ela pode fazer ótimo proveito de sua pouca percepção visual.

Uma pessoa com baixa visão também precisa ser avaliada cuidadosamente em relação às suas condições visuais, pois é a especificidade do caso que determina a melhor maneira de usufruir dos seus recursos visuais e de estratégias e instrumentos que maximizem sua potencialidade.

Mesmo que a particularidade seja uma variável de suma importância para a compreensão das pessoas com deficiência visual, Nunes e Lomônaco (2010) salientam que existe uma série de condições que são conhecidas, e que podem contribuir para o desenvolvimento da pessoa com deficiência visual, como os treinos de orientação e mobilidade, utilização de recursos ópticos e softwares de sintetização de voz.

\subsection{Preconceitos}

Um dos impedimentos mais importantes para o desenvolvimento pleno do indivíduo com deficiência, bem como a garantia de sua participação social efetiva, é o preconceito.

Apesar das melhoras significativas nas áreas de acessibilidade, tecnologia e políticas públicas para as pessoas com deficiência, as atitudes que temos em relação a estas pessoas são frequentemente retrógradas e provocam impedimentos para o aproveitamento das melhorias que ocorrem nas áreas supracitadas. Mesmo com acesso à educação, por exemplo, a baixa expectativa do professor e a discriminação por parte dos colegas e do restante da comunidade escolar podem interferir negativamente no processo de aprendizagem de uma criança com deficiência.

Na sociedade atual são vários os grupos de pessoas que são alvo de preconceito. Pessoas com deficiência, homossexuais, pessoas em condição de pobreza, pessoas oriundas de etnias diversas, pessoas em estado de obesidade, idosos, pessoas com transtornos mentais e tantos outros. O que há de comum entre estes grupos? Porque eles são alvo de preconceitos?

De acordo com Crochík (2006) o preconceito revela mais elementos sobre o preconceituoso e pouco sobre quem o sofre. Na verdade, para entendermos a formação do preconceito no indivíduo que o exerce, é preciso avaliar como estas ideias, que são 
distorcidas, formaram-se ao longo da história e que, portanto, fazem parte da cultura. Para este autor, o preconceito é manifestado pelo indivíduo por meio de pensamentos e atitudes, mas sua origem é predominantemente cultural, ou seja, o preconceito é herdado e transmitido socialmente.

Para Amaral (1998), certos grupos possuem características comuns entre si, mas que são percebidas como significativamente diferentes, por distanciarem-se do que é normativo. Por exemplo, podemos dizer que ser magro é normativo, portanto aqueles que não possuem esta característica são tidos como diferentes. Pode-se questionar o porquê de existirem características normativas, já que parece óbvia a afirmação de que todos temos diferenças. $\mathrm{O}$ fato é que certas diferenças se sobressaem e provocam reações negativas por parte daqueles que as temem.

A diferença significativa é estabelecida a partir de três parâmetros: o critério estatístico, o critério estrutural funcional e o tipo ideal (Amaral, 1998).

O critério estatístico refere-se a média ou a moda de certos atributos, como por exemplo a estatura média da população e a frequência de homens que exercem a profissão de motoristas de ônibus. Sendo assim, pessoas mais baixas ou mais altas do que a média são consideradas desviantes, bem como as mulheres que escolhem ser motoristas de ônibus.

O critério estrutural/funcional é estabelecido por características consideradas naturais para a estrutura e funcionamento do corpo humano como, por exemplo, ser bípede ou utilizar a visão como principal via sensorial e perceptiva. Embora seja difícil defender que uma condição seja natural, faz sentido pensar que existem condições normativas para o desenvolvimento humano na área da saúde e na própria psicologia. Neste sentido, a ciência tem um papel importante e pode, inclusive, formular teorias distorcidas a respeito da condição natural humana, fortalecendo ideologias preconceituosas.

Tanto o critério estatístico como o estrutural/funcional compõem, perversamente, o tipo ideal, que consiste do modelo de pessoas que devemos ser e que serve de referência para julgarmos a nós mesmos e aos demais. A medida que se afasta do tipo ideal, o indivíduo é usado para reafirmar a proximidade de outros em relação ao mesmo. São inúmeros os exemplos que podemos retirar do cotidiano, afinal, quem nunca ouviu uma mãe dizer para o filho que não pode desperdiçar alimento, porque tem gente passando fome? Ou, então, alguém que passa por um problema de saúde, mas sente-se confortado ao ver alguém em piores 
condições. Se um vestibulando pensa que teve um desempenho ruim em uma prova, sente-se melhor ao saber que muitos foram pior do que ele. Enfim, quando mais longe do ideal o outro estiver, mais próximo do ideal estarei.

O que torna o tema da diferença complexo é que, apesar de ser inquestionável o fato de que todos somos diferentes, algumas diferenças parecem importar mais do que outras. É neste ponto que entra a análise da cultura e das manifestações do preconceito: para a compreensão dos fatores que fortalecem a percepção das diferenças como ameaçadoras.

Segundo Crochík (2006), o preconceito é formado historicamente a partir dos conflitos presentes na luta do ser humano pela sobrevivência que geram medo e ansiedade. Estes sentimentos preparam os indivíduos para reagirem defensivamente frente a situações que possam lhes fazer mal. Entretanto, quando o imaginário passa a distorcer a realidade e o sujeito desenvolve mecanismos de defesa contra elementos que não se confirmam na realidade, está aberto o caminho para o preconceito.

O preconceito está ligado a diversos objetos, depende do que o indivíduo percebe como ameaçador para a sua integridade, por isso a afirmação de que o preconceito pouco tem a ver com seu alvo, e sim com quem o manifesta. Em cada relação de preconceito, um tipo de afeto é despertado, por isso fica difícil chegar a uma definição única de preconceito. Afinal, o preconceito em relação aos homossexuais não é igual ao preconceito contra as pessoas com deficiência, que por sua vez é diferente do preconceito contra os negros e assim por diante.

Apesar do preconceito não representar um conjunto único de formas e significados, algumas características estão presentes em qualquer situação em que ele se manifeste. Primeiramente, pode-se dizer que o preconceito significa uma conduta rígid (Masini, 1997)a frente a um objeto, construída a partir de uma percepção distorcida do mesmo e que, de alguma maneira, impede o contato genuíno que corrija tal percepção. Desta maneira, os preconceitos atuam como "filtros de nossa percepção" (Amaral, 1998, p. 17), impedindo o contato real com o objeto.

O fato é que, mesmo antes de conhecer qualquer pessoa com deficiência visual, já estão pressupostas uma série de coisas sobre elas, e este conhecimento conduz a atitudes que impedem a relação com o outro em sua autenticidade. Nestes casos, as informações sobre a deficiência parecem ser as únicas que importam para a percepção do sujeito, e acabam tomando o seu lugar. Amaral (1998) descreve este fenômeno como generalização indevida, 
em que "O indivíduo não é alguém com uma dada condição, é aquela condição específica e nada mais do que ela: é a encarnação da ineficiência total” (p. 17).

A generalização indevida é frequente, em relação ao sujeito com deficiência visual. Um exemplo ocorre quando, ao dirigir-se a um cego, a pessoa aumenta o tom de voz por entender que o déficit na visão torna o sujeito deficitário por inteiro. Ou então, ao invés de falar com o cego, a pessoa se dirige ao seu acompanhante vidente. São situações corriqueiras que demonstram que a condição da deficiência se antecipa à condição de sujeito.

Em um artigo de revisão, Nunes e Lomônaco (2010) alertam que o preconceito é um dos fatores que mais prejudica a escolarização do aluno cego. Além da falta de acessibilidade arquitetônica, de materiais pedagógicos e de profissionais preparados para atender as necessidades específicas destes alunos, a baixa expectativa em relação ao desempenho dos alunos cegos os segregam dos demais e impõe barreiras importantes para seu desenvolvimento. Dessa maneira, não se conhecem as capacidades de aprendizagem destes alunos e, por isso, os professores continuam a atuar com base no ensino para os videntes e deixam de atentar para as necessidades específicas do alunado com deficiência visual.

A situação de preconceito torna-se ainda mais preocupante quando influencia a percepção que o sujeito, alvo do preconceito, tem de si mesmo. Para Masini (1997) as atitudes de marginalização e de superproteção em relação a pessoa com deficiência visual resulta num conceito de si mesmo negativo, no qual predomina a falta de confiança em suas possibilidades.

Os preconceitos estão arraigados na cultura e participam da formação dos indivíduos, portanto é bastante provável que todos tenham percepções distorcida (Saúde, 2008)s em relação a determinados objetos. Entretanto, a cultura também desenvolve mecanismos de combate ao preconceito, que podem ser observados nos movimentos sociais, nas mudanças políticas e no discurso das pessoas. Esta contradição mantém a possibilidade de haver indivíduos não preconceituosos (Crochík, 2009).

Para que o preconceito seja superado, é necessário que a percepção do objeto possa ser ajustada à realidade. No caso das pessoas com deficiência visual, é preciso que suas potencialidades sejam exploradas e reconhecidas, deixando de lado a fixação no déficit e nas decorrentes impossibilidades impostas por ele. 
Adorno (2006) afirma que as ideias distorcidas, que são atribuídas aprioristicamente ao alvo do preconceito, podem ser desfeitas, ou ajustadas a realidade, pela experiência. Mas não se trata de qualquer experiência, mas daquela que proporciona uma reflexão que compare as ideias anteriormente formadas com o significado das novas experiências. Neste sentido, é preciso deixar de lado os julgamentos precedentes, para que se possa ter um contato genuíno com o outro e, dessa maneira, modificar a percepção.

Sendo assim, é preciso conhecer qualquer pessoa com deficiência, antes de tudo, como pessoa e, então, compreender como a deficiência confere a ela características específicas, que fazem parte de sua personalidade e de sua forma de aprendizagem.

\subsection{Inclusão escolar do aluno com deficiência visual}

Na sociedade contemporânea a educação ocupa um espaço importante. Logo cedo, espera-se que as crianças pequenas ingressem em instituições de ensino, dando início a um longo processo social chamado escolarização. No Brasil, o ensino básico (fundamental) possui caráter obrigatório e deve ser garantido pelo Estado a todos os cidadãos.

No Brasil tal direito está garantido pela Constituição Federal de 1988 e pela Lei de Diretrizes e Bases da Educação Nacional (LDB) de 1996, e o dever que as famílias e responsáveis têm de matricular seus dependentes legais é assegurado pelo Estatuto da Criança e do Adolescente (ECA), de 1990. Portanto a educação é um direito irrestrito e inalienável, ou seja, nenhum membro da sociedade pode ser privado da escolarização, seja por deficiência do Estado ou por decisão de seus responsáveis legais.

A educação das crianças com deficiência tem sido um tema amplamente discutido, em âmbito nacional e internacional, principalmente no que diz respeito à formulação de políticas de garantia de acesso e permanência de escolares com deficiência em escolas regulares, em situação de igualdade em relação às crianças sem deficiência. Podemos dizer, de maneira um tanto simplificada, que se discute a inclusão escolar, ou a educação inclusiva.

Definir o conceito de educação inclusiva não é uma tarefa fácil, uma vez que estamos nos referindo muito mais a um fenômeno histórico-social do que um termo científico propriamente dito. Sendo assim, a educação inclusiva pode ser discutida em diversos aspectos, começando pelos termos “educação" e "inclusão". Para isto, é necessário começar o 
estudo pela história da educação e pela análise do lugar que ela ocupa em uma certa organização social e em determinado momento histórico.

Seguidamente, encaminha-se o estudo para o significado da inclusão como fenômeno social, o que se mostra demasiadamente complexo por fazer parte do interesse de muitas áreas do conhecimento, como a filosofia, a sociologia, a psicologia, a pedagogia, e muitas outras. Soma-se a isto as vertentes divergentes em cada um destes segmentos e teremos uma ideia pouco coesa e discutível do termo inclusão.

Não é o objetivo deste trabalho expor as principais visões do tema e nem propor o consenso sobre o tema. Dentro de um conjunto de possibilidades, será utilizada a visão condizente com o campo de pesquisa explorado aqui sem, entretanto, carregar a ambição de que esta seja mais verdadeira do que as outras.

Considero importante esta série de ressalvas para não incorrer no erro de tratar a inclusão como algo já conhecido e com sentido único. Afinal, como alerta Bueno (2008):

Por estar na ordem do dia e por ser quase que uma unanimidade mundial, oferece a visão de que, quando nos referimos à "inclusão escolar", estamos tratando de um único fenômeno, conhecido por todos e que possui um único significado (p. 43)

De qualquer maneira, podemos destacar dois aspectos que parecem ser preponderantes em qualquer análise sobre a inclusão escolar, quais sejam: a dinâmica entre exclusão/inclusão e o direito à educação para todos.

Em relação ao primeiro aspecto, o próprio termo “inclusão" indica algo que está fora, excluído e, portanto, precisa ser incluído. Como isto se aplica às pessoas com deficiência?

Para Patto (2008) o conceito de exclusão possui relação direta com os modos de produção capitalista. Estar incluído na sociedade significa possuir potencial de trabalho válido e reconhecido para mover o desenvolvimento econômico e tecnológico. Sendo assim, aquele que, por qualquer razão, não é visto como possuidor desta força de trabalho, tem seu valor diminuído pela participação limitada dentro do sistema.

Quando a lógica da incapacidade predomina sobre a percepção em relação às pessoas com deficiência, seu potencial para o trabalho e, consequentemente, a possibilidade de participar da organização social são vistos como desiguais quando comparados às pessoas sem deficiência. Sendo assim, espera-se menos destas pessoas durante a escolarização e, quando chegam no mercado de trabalho, são tidos como vitoriosos. O ponto de destaque aqui 
é a baixa expectativa e exigência que recaem sobre aqueles que não correspondem ao trabalhador ideal.

Nos dizeres de Martins (1997, p. 14) "não existe exclusão: existe contradição, existem vítimas de processos sociais, políticos e econômicos excludentes". O autor postula que as minorias participam da sociedade de maneira perversa, pois ocupam espaços nas relações de produção do capital que não ameaçam a ordem vigente e, sobretudo, são silenciados na expressão da contradição existente. Para exemplificar este posicionamento podemos pensar nas empresas que empregam pessoas cegas apenas para setores de telemarketing, ou nas oficinas abrigadas de trabalho para aqueles que possuem deficiência intelectual. Dessa forma, os grupos são marginalizados pelo sistema, fundamentados na falsa ideia de que estão sendo nele plenamente incluídos.

O processo de inclusão educacional está sujeito a este mesmo problema: apesar do acesso à educação ser garantido, as minorias continuam à margem do que seria a educação ideal para os parâmetros atuais. Basta notar que, no discurso de professores, são frequentes frases como: "Tenho X alunos, mais Y de inclusão". Por mais que o professor seja bem intencionado em relação aos alunos "Y", sua verbalização demonstra que a condição de igualdade adotada na sala de aula é bastante questionável, uma vez que a sala não é percebida como um todo homogêneo e que, usualmente, o "aluno de inclusão" é aquele com algum tipo de deficiência ou distúrbio do desenvolvimento.

Aquilo que Martins (1997) caracteriza como inclusão precária, referindo-se às políticas econômicas que incluem as minorias nos setores básicos de produção, também pode servir para a análise da inclusão educacional, uma vez que as atuais políticas de inclusão educacional podem ocultar mecanismos de injustiça e desigualdade. Neste sentido o posicionamento teórico do referido autor é importante para a reflexão crítica sobre as práticas educacionais que estudamos, defendemos e participamos.

De forma mais ou menos marginalizada, o fato é que a inclusão educacional das pessoas com deficiência, principalmente daquelas que possuem deficiência visual, no Brasil, teve início no período imperial, no final do século XVIII e início do século XIX (Januzzi, 2004). 
Em meio a uma sociedade predominantemente rural, e também escravocrata, a educação especial ${ }^{3}$ surge para atender apenas pessoas que faziam parte da elite, notoriamente os cegos e surdos. Nesta época, o atendimento às pessoas com deficiência seguia os moldes do asilamento, retirando os sujeitos do convívio social mais amplo para retê-los em instituições especializadas (Bueno, 1993).

O ensino de cegos teve início com a criação do Imperial Instituto dos Meninos Cegos, em 1854, por iniciativa de pessoas ligadas ao Imperador, e que veio, anos depois, a chamar-se Instituto Benjamin Constant, existente até os dias de hoje (Januzzi, 2004).

Até o final da primeira metade do século $\mathrm{XX}$, as instituições especializadas predominaram e durante muito tempo e o desenvolvimento da educação especial acompanhou o lento desenvolvimento da educação como um todo. À medida que a educação regular se expandia, o atendimento às crianças com deficiência também se modificava, mesmo que em passos ainda mais lentos.

Neste período cresceu a influência da medicina e da psicologia sobre a educação das pessoas com deficiência, visto o interesse científico que estas áreas tinham pela identificação e reabilitação dos considerados desviantes (Bueno, 1993; Januzzi, 2004).

A partir do final da primeira metade do século XX, após passar por duas grandes guerras mundiais, a comunidade internacional empenhou esforços para a garantia dos direitos de igualdade a todas as pessoas. Disto resultou, em 1948, a Declaração Universal dos Direitos Humanos, uma importantíssima contribuição para a inclusão social e escolar das pessoas com deficiência, pois é garantido a todos os seres humanos uma série de direitos, inalienáveis e universais, que independem de qualquer condição física, social, cultural ou econômica. Dentre estes direitos está a educação.

Apesar deste marco importante, não houve uma mudança radical nas práticas relacionadas às pessoas com deficiência, mas todos os movimentos sociais em favor deste grupo, principalmente a partir da década de 1960 nos EUA, tomaram a Declaração Universal dos Direitos Humanos como referencial para suas reivindicações.

\footnotetext{
3 Adota-se o termo educação especial como aquela voltada para o atendimento centrado no aluno que possui necessidades específicas para o processo de escolarização, as quais não são comtempladas pelas técnicas convencionais de ensino.
} 
No Brasil houve um crescimento no atendimento aos alunos com deficiência nas redes pública e privada de ensino, segundo Bueno (Mazzotta, 1982) (1993). Este crescimento resultou no desenvolvimento de técnicas mais sofisticadas de reabilitação e no fortalecimento das instituições especializadas que ofereciam este serviço. No âmbito político, as classes mais altas influenciavam o governo na criação de políticas públicas de educação especial.

Na década de 1970, a educação especial foi eleita uma das prioridades das políticas públicas educacionais (Januzzi, 2004), sendo elaborados diversos projetos importantes, como a criação do Centro Nacional de Educação Especial (CENESP) e, posteriormente, na década de 1980, a criação da Coordenadoria Nacional para Integração da Pessoa Portadora de Deficiência (CORDE).

Nos anos 80 do século passado, foram estudadas formas mais eficazes de promover a participação social da pessoa com deficiência, a começar pela educação. Mazzotta (1982) entendia que o acesso de pessoas com necessidades educacionais especiais à educação (regular ou especial) deveria ocorrer por meio da sistematização da avaliação das condições do aluno e dos recursos educacionais disponíveis. Havia um modelo classificatório, que indicava o grau de integração que o aluno com deficiência possuía, de acordo com o seu desempenho junto às classes comuns. A grosso modo, o aluno caminhava da classe especial para a classe comum, passando por etapas preparatórias.

Este modelo ficou conhecido como integração, no qual a pessoa com deficiência deve ser preparada gradativamente e progredir de acordo com o seu desempenho rumo às atividades coletivas consideradas "normais".

Foram diversos os problemas decorrentes deste modelo. Dentre eles, Ferreira (1993) aponta que os alunos com deficiência mental leve que frequentavam classes comuns foram movidos para as classes e escolas especiais. Para o autor, o que se concretizou foi a negação das particularidades educacionais destes alunos na sala comum, evitando assim a necessidade de modificar as práticas pedagógicas vigentes em favor deste alunado. Com isto, a educação tenderia mais à segregação do que a integração propriamente dita.

Além disso, Bueno (1993) afirma que afirma que, mesmo com o aumento do acesso à educação por este público ter crescido historicamente, ela não acompanhou a popularização da educação como um todo e, pior, manteve a segregação por meio da manutenção das classes 
especiais (formadas a partir de critérios médicos e psicológicos) e pela concentração dos excepcionais pertencentes às classes sociais mais elevadas nas escolas especiais particulares.

Enfim, o principal problema continuou sendo o direito de igualdade oportunidades e condições no campo educacional. A comunidade internacional também denunciava a não garantia destes direitos em diversas partes do mundo. Em 1990 foi realizada a Conferência Mundial sobre Educação para Todos, na cidade de Jomtien, Tailândia. Deste encontro, originou-se a Declaração Mundial da Educação para Todos.

Poucos anos depois, em 1994, ocorreu outro encontro internacional que continuou a discussão sobre a educação para todos. Os trabalhos ocorreram da cidade de Salamanca, Espanha, e deram origem a um documento que assinalou o compromisso de mais de 80 países no empenho de melhorias dos sistemas educacionais.

Foi neste período de efervescentes discussões sobre a educação que surgiu na nova LDB - Lei $n^{\circ}$ 9.394/96 - carregada de expectativas de avanços significativos nos parâmetros da educação nacional e, com isto, progresso em relação às políticas de atendimento à população com necessidades educacionais especiais.

Não está ao alcance deste trabalho, e nem é este o objetivo, avaliar em que nível as expectativas daqueles que estiveram engajados nos movimentos a favor da educação para todos foram atendidas. Cabe, porém, ressaltar que a nova LDB dá continuidade às praticas já existentes e oficializa a educação especial como modalidade de ensino, conforme o Artigo 58 "Entende-se por educação especial, para os efeitos desta Lei, a modalidade de educação escolar, oferecida preferencialmente na rede regular de ensino, para educandos portadores de necessidades especiais” (Brasil, 1996).

Ainda que não seja conclusiva em relação ao encaminhamento institucional dos alunos com necessidades educacionais especiais, a nova LDB consiste em um marco importante para as políticas públicas nacionais. Além disso, as declarações de Jomtien e Salamanca continuam influenciando diretamente as novas políticas e os movimentos sociais pela inclusão.

Além das duas declarações supracitadas, temos também a Convenção sobre os Direitos das Pessoas com Deficiência, homologada em dezembro de 2006 pela Organização das Nações Unidas (ONU). Este documento é particularmente importante, uma vez que o Estado brasileiro é signatário da Convenção e, por meio do Decreto $n^{\circ} 6.949$, de 25 de agosto 
de 2009, ratificou as recomendações do documento. Isto quer dizer que, a partir da data do decreto o Brasil, oficialmente, deve cumprir com as pautas presentes na Convenção.

O artigo 24 desta convenção versa sobre a educação das pessoas com deficiência. Os alunos com deficiência visual são diretamente mencionados no item 3-c, no qual os Estados devem tomar as medidas politico educacionais:

Garantindo que a educação de pessoas, em particular crianças cegas, surdocegas e surdas, seja ministrada nas línguas e nos modos e meios de comunicação mais adequados ao indivíduo e em ambientes que favoreçam ao máximo seu desenvolvimento acadêmico e social (CORDE, 2007, p. 29)

É fato que medidas como esta têm sido desenvolvidas ao longo dos anos, afinal o braile é ensinado nas salas de recursos das escolas regulares e utilizado pelo aluno na sala comum, por exemplo. Entretanto, também podemos observar que nem sempre os meios de comunicação referidos na citação acima seguem uma orientação inclusiva, por isso a Convenção sobre os Direitos das Pessoas Deficiência é importante como um todo, pois ressalta que a educação deve ser “inclusiva em todos os níveis”. (CORDE, 2007, p. 28)

Embora as políticas públicas sejam de indiscutível importância para a educação inclusiva, ela não se constitui apenas neste nível. Na verdade a inclusão é algo mais amplo, como salienta Amiralian (2009) "A Inclusão é uma organização social em que todos somos considerados iguais" (p. 22). Neste contexto, igualdade significa que todos têm os mesmos direitos e deveres, ainda que todos sejam diferentes em algum aspecto.

Antes de mais nada, a inclusão deve ser entendida como um valor social, e que também faz parte da escola, já que esta reflete os modelos sociais em vigor. Apesar destes modelos reproduzirem condições de desigualdade e preconceito, existe, contraditoriamente, o desejo de alcançar a igualdade e a justiça.

A educação inclusiva reflete este ensejo coletivo, na busca de proporcionar a condição de igualdade de direitos e oportunidades que deveriam permear todas as áreas da sociedade. Em conformidade com este pressuposto, Mittler (2003) define:

No campo da educação, a inclusão envolve um processo de reforma e de reestruturação das escolas como um todo, com o objetivo de assegurar que todos os alunos possam ter acesso a todas as gamas de oportunidades educacionais e sociais oferecidas pela escola. Isto inclui o currículo corrente, a avaliação, os registros e os relatórios de aquisições acadêmicas dos alunos, as decisões que estão sendo tomadas sobre o agrupamento dos alunos nas escolas ou 
nas salas de aula, a pedagogia e as práticas de sala de aula, bem como as oportunidades de esporte lazer e recreação. (p. 25)

Neste sentido, a inclusão escolar não se restringe apenas às pessoas com deficiência, mas a todas aquelas que são, por algum motivo, marginalizadas socialmente por apresentarem características diferenciadas daquilo que é normativo dentro da organização social.

É preciso ter cuidado ao colocar as pessoas com deficiência visual na mesma categoria de todos aqueles grupos abrangidos pela inclusão escolar. A inclusão é para todos, mas para que se possa garantir esta igualdade é necessária a atenção às condições específicas das pessoas com deficiência visual, para o desenvolvimento de melhores estratégias para a aprendizagem deste alunado.

Para tanto, entende-se que é preciso, sobretudo, que os envolvidos com a educação das pessoas com deficiência visual consigam perceber suas necessidades reais e compreender que o cego estrutura sua cognição de forma diferente do vidente. Por isso o diálogo entre os profissionais e as pessoas com deficiência - sobretudo os profissionais com deficiência que atuam na educação - neste processo é fundamental (Amiralian, 2009).

É importante, também, a aproximação entre os profissionais da educação e as teorias psicológicas que abordam os processos de aprendizagem para que se compreenda os mecanismos de construção do conhecimento nos alunos.

Neste trabalho será abordado o processo de formação de conceitos, assim como as principais teorias existentes a respeito deste tema. Acreditamos que a psicologia da formação de conceitos pode colaborar significativamente com o desenvolvimento de estratégias educacionais eficientes na tarefa de atender às diversas demandas de aprendizagem presentes nas escolas de hoje.

Não obstante tais teorias tem sido desenvolvidas com base nas pessoas videntes, o conhecimento gerado por elas possuem um certo grau de generalidade aplicável à aprendizagem da pessoa cega. 


\section{CAPÍTULO 2}

\section{FORMAÇÃO DE CONCEITOS E DEFICIÊNCIA VISUAL}

Amiralian (1997) salienta que o processo de formação de conceitos é uma das áreas de maior dificuldade no desenvolvimento cognitivo da criança cega, dada a importância da visão para integrar as informações captadas pelos outros sentidos. A autora afirma que: "Inundada por estímulos sonoros e táteis-cinestésicos, sem a ajuda da visão, a criança terá dificuldades em dirigir sua atenção de modo a apreender os atributos essenciais e organizar suas experiências em conceitos prontamente identificáveis" (p. 66).

A construção de imagens mentais, necessária para o desenvolvimento do pensamento simbólico e para a formação da realidade interna da criança, ocorre de maneira diferenciada nas crianças cegas. De acordo com Oliveira e Bomtempo (2009), a internalização da realidade física ocorre por meio da exploração livre do ambiente, do exercício de transitar por diversos caminhos no espaço e, dessa maneira, guardar na memória os caminhos percorridos. Num primeiro momento, é espontânea a ideia de que a visão ocupa lugar central neste processo, mas as autoras ressaltam que, no caso das crianças cegas, deve haver uma compensação feita pelos outros sentidos, destacadamente a audição, permitindo que a criança possa internalizar o espaço físico. Quanto mais a criança praticar a autonomia na locomoção e na exploração do ambiente, principalmente por meio do brincar, melhor será sua construção simbólica.

A internalização do ambiente externo na forma de representações mentais é fundamental para que a criança desenvolva a linguagem e a abstração. Desta maneira, a construção da linguagem pelas crianças cegas ocorre da mesma forma do que pelas videntes ${ }^{4}$, porém sem o uso da visão. Além disso, Amiralian (1997) ressalta que é importante avaliar em que momento do desenvolvimento o sujeito perdeu a visão e como ocorreu esta perda: aos poucos, como em função de uma doença; ou de forma súbita, como em um acidente que provoca lesão do aparelho visual. A perda ou alteração visual impacta de maneira diferente cada sujeito, tanto no aspecto do desenvolvimento cognitivo quanto na formação da personalidade, portanto faz sentido afirmar que cada sujeito estabelece uma relação particular com a deficiência visual.

\footnotetext{
${ }^{4}$ Termo utilizado para representar aqueles que não possuem deficiência visual.
} 
Ainda sobre o desenvolvimento das crianças com deficiência visual, Lewis (2003, citado por Batista, 2005) afirma que o desenvolvimento da inteligência e o processo de formação de conceitos em crianças cegas é praticamente igual ao das crianças sem esta deficiência e assume que a linguagem atua de maneira compensatória à falta de visão. De acordo com este autor, a linguagem torna-se a principal via de interação com o meio externo, permitindo ao cego conhecer de maneira integral. Por esta razão as diferenças na aprendizagem de conceitos por crianças cegas e videntes pode, num primeiro momento, ocorrer sem diferenças significativas.

Sabe-se que as pessoas cegas são capazes de formar conceitos e de utiliza-los em suas atividades diárias, assim como o fazem as pessoas que possuem visão. Nunes (2004) salienta que o cego possui uma organização sensorial diferente, o que não significa impedimento para o seu desenvolvimento cognitivo. No entanto isto não significa que, durante o processo de aprendizagem, a pessoa cega não precise contar com adaptações e recursos específicos que garantam a aquisição do conhecimento, principalmente dentro de uma cultura escolar orientada para pessoas que enxergam.

Apesar da abundância de recursos pedagógicos e tecnológicos para o ensino de pessoas com deficiência visual, para os cegos congênitos, no processo de aquisição de conceitos, a adaptação mais importante parece ocorrer por meio da linguagem oral, pela comunicação com as pessoas videntes.

Nunes e Lomônaco (2010), Nunes (2004) e Amiralian (1997) afirmam que, sem acesso às informações visuais para a formação de certos conceitos, valem-se do tato e da audição. Porém, como é possível utilizar estes sentidos para adquirir o conceito de arco-íris? Ou então o conceito de "lua"? É neste ponto que a linguagem desempenha seu papel, como uma forma eficaz de codificar as informações visuais em sinais acessíveis aos cegos.

A partir das definições verbais fornecidas por outrem, os cegos formam suas representações mentais daqueles conceitos que não poderiam, a princípio, serem conhecidos por outros sentidos além da visão.

Entretanto, Amiralian (1997) faz a ressalva de que estes conceitos podem ser pouco precisos, uma vez que são "importados" de pessoas que enxergam e, portanto, são construídos a partir de experiências visuais que não fazem parte da estrutura cognitiva do cego. A consequência disto é a formação de conceitos distorcidos ou sem significado para a pessoa. 
Outra questão é que, se entendermos que o cego adquire alguns conceitos pela verbalização das pessoas videntes, fica estabelecida uma relação de dependência das informações visuais (Nunes e Lomônaco, 2010), o que não permitiria ao cego formar representações mentais de acordo com as suas estratégias cognitivas específicas e leva-los a formar conceitos.

Mas o que são conceitos e como eles são formados?

\subsection{Dificuldades na definição de conceito}

Responder a esta questão não é uma tarefa simples e tampouco é o objetivo principal deste trabalho. Dentro do âmbito da psicologia, a reflexão sobre o processo de formação de conceitos levou à realização de inúmeras pesquisas importantes e à elaboração de diferentes teorias sobre como ocorre este processo. No entanto, não há consenso entre os estudiosos sobre qual a definição de conceitos é mais adequada, embora não se negue a existência e a importância dos conceitos para a sobrevivência do homem.

Embora não haja dúvidas de que formamos conceitos, sua definição ainda é objeto de muitas discussões em face das muitas dificuldades implicadas nesta tarefa. Flavell (1976) aponta três dificuldades fundamentais para a definição do que seja um conceito. Primeiramente, são praticamente infinitas as entidades que podem ser consideradas como conceitos. Em segundo lugar, é difícil encontrar atributos que sejam comuns a todas as entidades que são consideradas como conceitos. Por fim, as entidades podem ser muito diferentes umas das outras. Na verdade, as diferenças ultrapassam em muito as similitudes. Flavell, fundamentado em Klausmeier et al. (1965) afirma que os conceitos diferem, pelo menos, em sete aspectos, quais sejam:

1) Atributos: a natureza dos elementos que formam os conceitos pode ser originário de qualquer aspecto percebido ou elaborado pelo ser humano. De acordo com este autor, qualquer estímulo que pode ser capturado pelos sentidos ou elaborado intelectualmente pode ser considerado como atributo de um conceito. Sendo assim, formar um conceito implica em reunir diversos atributos que dão origem a uma definição. Os atributos podem corresponder a propriedades físicas, como tamanho e cor; propriedades funcionais, uma vez que os objetos também podem ser "comestíveis", "solúveis, etc., ou propriedades relacionais, quando os 
atributos referem-se às relações do objeto em um sistema de inter-relações, para referir-se ao livro mais vendido num conjunto de outros livros.

2) Estrutura: refere-se à forma como os atributos se organizam na formação de um conceito. A estrutura de um conceito pode ser conjuntiva, disjuntiva ou relacional (Bruner et al, 1956, citado por Lomônaco, 1997). Conjuntiva é aquela em que são necessários ao menos dois atributos para a definição de um conceito. Um quadrado, por exemplo, é definido como uma "figura plana" com "quatro lados" e "ângulos retos". Um conceito é relacional quando, para sua definição, é necessário o conhecimento do sistema ou rede de conceitos no qual ele está inserido e do qual faz parte. Os conceitos de parentesco ilustram bem a ideia de conceito relacional. Por exemplo, o conceito de "mãe" só pode ser entendido e definido em face das relações com outros conceitos. Já os conceitos de estrutura disjuntiva são aqueles em que apenas um atributo definidor é suficiente para definir o conceito, ao contrário da estrutura conjuntiva. Neste caso, mesmo que o conceito possa ter mais de um atributo definidor é suficiente a presença de apenas um deles para incluir o exemplo na categoria. Lomônaco (1997) exemplifica a estrutura disjuntiva com o conceito de "falta" no futebol, a qual pode incluir comportamentos tais como "colocar a mão na bola" ou então "agredir fisicamente ao adversário" ou "ofender o juiz verbalmente" ou "retardar a devolução da bola", etc. Neste exemplo, qualquer um dos atributos é isoladamente suficiente para que se tenha o conceito de falta no futebol. Um segundo exemplo, mais próximo do tema deste trabalho, é o conceito de deficiência, que pode ser definido pela perda ou pela alteração de estrutura $o u$ função psicológica, anatômica ou fisiológica. Em um grau de menor generalidade, a deficiência visual pode ser exemplificada pela cegueira $o u$ baixa visão.

3) Abstração: os conceitos podem ser mais ou menos abstratos, dependendo do nível de acessibilidade dos mesmos pelas vias sensoriais. Um conceito é pouco abstrato quando seus atributos podem ser facilmente captados pelos sentidos. Atributos e exemplos mais abstratos são aqueles comumente formados pela linguagem verbal, uma vez que não possuem representação concreta ou real. Por exemplo, o conceito "justiça” é uma abstração feita a partir das relações humanas, mas não pode ser diretamente observada na realidade concreta. Um exemplo de conceito que não possui qualquer tipo de referencial na realidade é o conceito de "Deus" (Lomônaco, 1997). 
4) Inclusão: diz respeito à abrangência de exemplos que um conceito abarca. Existem conceitos que não possuem nenhum exemplo, como "sereia", e conceitos com infinitos exemplos, como "estrelas".

5) Generalidade: aqui é considerada a relação hierárquica do conceito dentro de uma rede conceitual da qual ele faz parte. A relação é direcionada dos conceitos mais gerais para os mais específicos. Por exemplo, "mamífero" é um conceito mais geral do que "cão", que por sua vez, é mais geral do que "labrador".

6) Precisão: quando os atributos que fazem parte da definição do conceito são estabelecidos de acordo com regras bem específicas, afirma-se que o conceito é preciso, ou seja, para sabermos se um exemplo representa o conceito, basta observar se o mesmo possui os atributos especificados na definição. Exemplos: "número primo" ou "quadrilátero". Assim, quanto menor for a precisão dos atributos, mais subjetivo será o conceito, como em "obra de arte", por exemplo.

7) Poder: são considerados "poderosos" aqueles conceitos que ocupam uma posição central em uma determinada área do conhecimento, de forma que o seu domínio é prérequisito para a aprendizagem de outros conceitos. $\mathrm{Na}$ área da Psicologia podemos considerar os conceitos de "inconsciente" para a psicanálise, "esquema" para a teoria piagetiana ou "condicionamento" para o behaviorismo, como conceitos poderosos.

\subsection{Teorias ou visões sobre a formação de conceitos}

A preocupação com a natureza dos conceitos não nasceu com a Psicologia, mas já estava presente na Filosofia desde Platão e Aristóteles (Lomônaco, 1997) e continuou objeto de interesse dos filósofos ao longo dos séculos. Na Psicologia, o estudo científico dos conceitos iniciou-se no início do século XX, a partir do trabalho pioneiro de Clark Hull, em 1920. A partir daí desenvolveram-se diferentes teorias a respeito dos conceitos. As principais teorias ou visões, psicológicas sobre conceitos são a visão clássica, a prototípica, a dos exemplares e a teórica.

Segundo a visão clássica, os conceitos são formados pela presença necessária e suficiente de atributos que são comuns a todos os membros de uma categoria. 
A visão clássica de conceitos pressupõe que a representação mental de um conceito é formada a partir da experiência do ser humano com diversas entidades diferentes, mas que possuem atributos comuns, e é a partir da abstração desses atributos que uma representação mental é formada. Segundo Lomônaco (1997) “o indivíduo, ao formar um conceito, sumariza ou resume numa única representação características partilhadas por todos os subconjuntos de uma classe ou mesmo por exemplos específicos." (p. 46). Temos, portanto, uma das características fundamentais da visão clássica: a partir da abstração dos elementos comuns a todos os exemplos de uma classe, é possível formar uma representação aplicável a qualquer exemplo da categoria. Ou seja, ao entrar em contato com diversos exemplos do conceito "mesa", abstraímos as características "pernas" e "tampo". Explorando um pouco mais o exemplo do conceito “mesa", pode-se conhecer outro princípio da visão clássica: não importa o tipo, tamanho, local ou função da mesa, mas a presença conjunta dos atributos definidores deve estar presente. Portanto os subconjuntos do conceito (como mesa de jantar, escrivaninha, mesa de centro, etc.) possuem os mesmos atributos definidores do conceito "mesa", conjuntamente com seus atributos específicos

De acordo com o mesmo autor, os atributos definidores formam um conjunto que não pode ser dissociado, por exemplo: se adotamos como conceito de triângulo "uma figura plana, fechada, de três lados", então todo exemplo deve possuir estes três atributos simultaneamente, do contrário não será um triângulo, ou seja, os atributos definidores são individualmente necessários (sem algum deles o conceito não pode ser definido) e conjuntamente suficientes (na definição do conceito, todos estes atributos devem estar presentes).

Ainda que a visão clássica tenha predominado no estudo dos conceitos da década de 1920 até por volta de 1970, esta teoria apresenta limitações importantes.

Lomônaco, Caon, Heuri, Santos e Franco (1996), apontam três limitações importantes à visão clássica, quais sejam:

1. Dificuldades em especificar os atributos definidores de conceitos naturais: apesar da possibilidade de definir diversos conceitos, nota-se que a maioria dos conceitos cotidianos não obedece os princípios da visão clássica. Por exemplo, os atributos definidores do conceito cão podem ser "latir", "ter o corpo coberto por pêlos" e "ter quatro patas". Porém, mesmo que o cão não possa latir, não tenha pêlos ou tenha alguma de suas patas faltando, ele não deixa de ser um cão. 
2. A existência de exemplos cuja inclusão na categoria é incerta ou duvidosa: alguns objetos dificilmente podem ser incluídos em uma só categoria. Por exemplo: "lenço" é vestimenta ou acessório? "Xadrez" é jogo ou esporte? "Bicicleta" é brinquedo ou meio de transporte?

3. A diferente representatividade dos membros de uma categoria: a afirmação de que todos os exemplos de um conceito possuem a mesma representatividade, não parece se adequar à nossa percepção imediata, já que certos exemplos de um conceito realmente parecem ser mais representativos do que outros. Por exemplo, "maçã" e "laranja" parecem-nos exemplos mais representativos do conceito de fruta do que "cacau" ou "açaî".

Em face das limitações apresentadas, uma nova teoria de conceitos é proposta: a visão prototípica. A maior expoente desta teoria de conceitos foi Eleanor Rosch que, em um famoso experimento sobre a percepção de cores, constatou que alguns tons de uma cor são mais representativos do que outros. Rosh (1978), demonstrou que nem todos os exemplos são igualmente representativos do conceito, o que contrariou radicalmente o postulado da visão clássica. A partir deste ponto, a pesquisadora deu início ao desenvolvimento da visão prototípica, também conhecida como visão probabilística, ou visão natural.

A visão prototípica postula que a formação de conceitos se dá pela percepção de características típicas ou mais frequentes entre os elementos de uma categoria. Ao entrar em contato com vários exemplos de uma mesma categoria, abstraímos os atributos que aparecem com maior frequência e, com eles, formamos uma representação mental que abarca os exemplos do conceito. Tal representação mental é o protótipo. Ou seja, o conceito é formado a partir dos atributos mais prováveis, consistindo numa representação sumária das características mais comuns à categoria. Os novos exemplos serão incluídos ou excluídos da categoria de acordo com a proximidade ou similaridade em relação ao protótipo. Ou seja, a representatividade do conceito é definida pela sua proximidade ao protótipo. Quanto mais o próximo do protótipo, mais representativo será o exemplo, e quanto mais distante, menor a sua representatividade.

A partir da visão prototípica, desenvolveu-se uma outra teoria de conceitos, que pode ser considerada como uma variante da visão prototípica: a visão dos exemplares. Esta visão postula que o indivíduo toma um ou alguns exemplos individuais como representantes da 
categoria, as quais servirão como uma base de comparação para a inclusão de novos elementos em uma categoria. Ao contrário da visão prototípica, em que o conceito é compreendido como representação sumária, o conceito é representado por um ou alguns poucos exemplos concretos. Para ilustrar a perspectiva desta visão de conceitos, vamos considerar um professor que, durante sua carreira docente, entrou em contato com muitos e muitos alunos. No decorrer de sua trajetória, o professor terá um ou vários exemplos de "bom aluno", que adotará como representação deste conceito, ou seja, um ou alguns poucos exemplos que expressem o significado de "bom aluno". Desta maneira, todo novo exemplo será comparado com a referência, antes que seja incluso (ou não) na categoria.

Embora existam muitas e sérias divergências entre as três visões brevemente apresentadas, todas partilham de um aspecto comum: em todas elas a similaridade é o fator responsável por manter os membros de uma categoria agrupados. O agrupamento de exemplos de um conceito dentro de uma categoria é denominado coesão conceitual. Na visão clássica o fator responsável pela coesão conceitual são os atributos comuns a todos os componentes da categoria, na visão prototípica é a similaridade dos exemplos em relação ao protótipo; e, na visão dos exemplares a similaridade com o exemplo de referência (Lomônaco, 1997).

No entanto, Murphy e Medin (1985, citado por Lomônaco, 1997) salientam que a similaridade não é suficiente para explicar a coesão conceitual o que implica em limitações importantes a essas teorias. A mais séria delas diz respeito a que atributos devem ser considerados na formação de um conceito, uma vez que a similaridade não estabelece critérios rígidos para a inclusão ou exclusão exemplos à categoria. Baseados no princípio da similaridade, podemos encontrar uma enormidade de correspondências entre dois objetos quaisquer. Por exemplo, "laranjas" e "aspiradores de pó" compartilham uma série de atributos comuns: ambos tem peso, são compostos de matéria, possuem densidade, ocupam lugar no espaço, etc. mas, não obstante, não são incluídos na mesma categoria em todas as culturas conhecidas. O fato é que a similaridade é um fato demasiadamente flexível, o que não permite explicar a coesão conceitual. Sendo assim, parece que deve existir algum outro fator que determine a percepção de certas semelhanças e não de outras. Tal constatação nos coloca frente a problemas cruciais no estudo de conceitos. Que fator determina a coesão conceitual? Afinal, o que mantém nossos conceitos unidos? Ou, em outras palavras, porque temos os conceitos que temos e não outros? 
A partir das criticas apresentadas às três visões consideradas, desenvolveu-se, a partir da década de 80 do século passado, uma nova forma de entender o processo de formação de conceitos: a visão teórica.

No ano de 1985 foram publicados trabalhos que deram surgimento a esta visão de conceito, a saber: o livro Conceptual Change in Childhood, por Susan Carey e o artigo de Gregory L. Murphy e Douglas L. Medin intitulado The Role of Theories in Conpeptual Coherence (Lomônaco, 1997). Entretanto, foi o psicólogo norte-americano Frank C. Keil que se destacou como o principal divulgador da visão teórica, por conduzir uma série de pesquisas sobre a formação de conceitos em crianças que o levou a construir um modelo importante sobre este processo psicológico.

Para a visão teórica, os conceitos não são formados somente a partir da junção de atributos definidores, ou pela ocorrência frequente de certos atributos, mas fundamentalmente pelas relações que mantém com outros conceitos (Lomônaco, 1997; Oliveira, 1999), ou seja, cada conceito faz parte de uma rede de outros conceitos com os quais se relacionam.

Como afirma Lomônaco (1997) "o conceito não mais é visto isoladamente, mas como parte de uma rede de relações com outros conceitos da qual deriva o seu significado" (p.162). Mas, como estas redes de relações são formadas?

De acordo com Keil (1989) as relações entre os conceitos, em um domínio de conhecimento, não se dão de forma arbitrária. Existe uma certa coerência entre os conceitos que formam uma rede, o que o leva à formação de sistemas relativamente organizados. Para o autor, a causalidade é o fator que mantém a coesão conceitual. Organizamos nossos conceitos não pela similaridade dos atributos, mas pelas relações causais existentes entre os mesmos. $\mathrm{O}$ autor explica que estas relações funcionam como sistemas de crenças, formadas a partir do conhecimento de mundo que temos.

As teorias formadas pelos sujeitos derivam-se das experiências da vida diária e, nesse sentido, constituem-se em teorias ingênuas a respeito do mundo (Oliveira, 1999, p. 128). As teorias são consideradas/denominadas ingênuas porque diferem em sua formação da teorias científicas. Por exemplo, mesmo sem estudar psicologia as pessoas possuem uma ideia sobre a depressão, e também sabem empregar o termo "surto" para designar o comportamento estranho ou nervoso de alguém. Temos, desse modo, uma psicologia ingênua, que permite interpretar e explicar o comportamento humano. Da mesma maneira, existe uma biologia 
ingênua uma vez que sabemos que os seres vivos nascem, se alimentam, crescem, reproduzem e morrem (Lomônaco, 1997).

Segundo Keil (1989), as relações causais que mantém os conceitos criam uma homeostase causal, que é a responsável pelo equilíbrio interno entre todos conceitos que formam a rede ou o sistema. Sendo assim, se algum conceito é modificado pela experiência, ou se uma nova informação é capturada por esta rede, todo o sistema é alterado em algum nível. A rede é dotada de certa plasticidade, pois reorganiza-se à medida que novas experiências são agregadas.

O papel da homeostase causal é central para compreensão psicológica do conceito. A partir daí podemos entender como, ao longo do desenvolvimento, nossos conceitos modificam-se qualitativamente.

A visão teórica representa, para a psicologia, uma nova maneira de compreender o desenvolvimento conceitual. Esta visão apresenta diferenças importantes em relação às teorias mais conhecidas nesta área (como as de Vygostsky, Piaget e Bruner), como a refutação da reorganização global dos domínios conceituais. Dentro deste novo paradigma, o desenvolvimento conceitual se dá, qualitativamente, pela mudança de atenção das propriedades características às propriedades definidoras no processo de formação de conceitos. De acordo com Lomônaco et al. (1996), os atributos definidores são aqueles que, embora possam ser frequentes na definição de um conceito, não são necessários para sua definição. Por outro lado, os atributos definidores, como o nome já indica, são aqueles necessários e suficientes para a definição do conceito. Vejamos como exemplo o conceito "avó": definir este conceito como "uma mulher carinhosa, que sua óculos e gosta de cozinhar" é bastante comum, mas estes atributos não fazem parte da definição, pois são apenas característicos. Entretanto, a definição de avó como "a mãe da minha mãe" se utiliza propriedades definidoras e permite definir o conceito de forma precisa.

A atenção predominante aos atributos característicos é próprio de crianças pequenas. No decorrer do processo de desenvolvimento cognitivo ela será gradual e naturalmente mudada para a atenção nos atributos definidores. Ou seja, as teorias ingênuas tendem a ser constituídas predominantemente por atributos característicos, não essenciais à definição do conceito. À medida em que o sujeito se torna mais velho, os atributos passam a ser 
predominantemente definidores, ou seja, há uma maior aproximação a uma teoria mais científica.

Keil (1989) realizou diversos experimentos para identificar as mudanças que ocorrem nas teorias ingênuas ao longo do tempo. Lomônaco et al. (2001) replicaram três de seus experimentos em nossa cultura. Um deles consistiu em narrar histórias sobre transformações em espécies naturais e artefatos. $\mathrm{O}$ experimento teve por objetivo verificar se as crianças, ao entrar em contato com as mudanças ocorridas nas histórias, poderiam explicar as mudanças a partir de atributos característicos ou definidores.

Neste experimento, foram traduzidas seis histórias utilizadas originalmente por Keil e narradas para 30 crianças de idades entre 6 e 11 anos, subdividos em três grupos de dez sujeito, de acordo com faixa etária. Quatro histórias narravam a transformação de espécies naturais (cavalo/zebra, tigre/leão, frango/peru, chumbo/ouro) e duas de artefatos (gravata/cadarço de sapato, lata de lixo/cadeira). As histórias das espécies naturais consistiam em situações fictícias nas quais os animais e objetos passavam a ter uma grande quantidade de atributos característicos que os tornavam semelhantes a outros animais/objetos (por exemplo, um cavalo que ficava com o pelo listrado como o de uma zebra). Nas histórias dos artefatos, os objetos eram submetidos a alguma operação que os transformavam em outros artefatos efetivamente, como cortar uma gravata em pequenas tiras, colocar um tubinho plástico nas pontas e utilizá-la como cadarço de sapato.

A narração das histórias foi feita individualmente para cada uma das 30 crianças, sempre na mesma ordem. Após ouvir a história, a criança devia escolher a figura, mostrada pelo experimentador, que representava a transformação da espécie natural ou artefato. A fim de esclarecer melhor a escolha do sujeito, o experimentador realizava perguntas à guisa de justificativa.

O estudo realizado corroborou os resultados de Keil, confirmando que: a) à medida que as crianças vão se tornando mais velhas, passam a atentar mais para os atributos definidores dos conceitos, com a consequente diminuição da utilização dos atributos característicos; b) há uma diferença qualitativa entre o desenvolvimento de conceitos pertencentes às espécies naturais e os correspondentes a artefatos, sendo estes últimos os aqueles em que há maior facilidade em construir teorias a partir dos atributos definidores (Lomônaco et al., 2001). 
Os resultados do experimento de Keil (1989) e Lomônaco et al. (2001) demonstram que o desenvolvimento dos domínios conceituais evolui, do característico para o definidor, gradativamente de acordo com a idade, mas não de maneira uniforme para todos os domínios conceituais. Por exemplo, mesmo tendo demonstrado facilidade em reconhecer os atributos definidores dos artefatos, as crianças demonstraram mais dificuldade com os conceitos naturais. Portanto, existe uma diferença no processo de formação de conceitos ligada aos diferentes domínios conceituais, ao contrário do que é usualmente postulado pelas teorias do desenvolvimento e aprendizagem de Piaget, Bruner, Vygotsky, entre outros (Lomônaco, 1997).

\subsection{O uso de recursos tecnológicos para aprendizagem em crianças cegas}

Embora saiba-se que as pessoas com deficiência visual são tão capazes de aprender como qualquer outra pessoa, não se pode deixar de considerar que sua organização sensorial lhe confere características específicas para a aprendizagem. Isto significa que para aprender certas coisas, como ler e escrever, por exemplo, é necessária a utilização de recursos que atendam as especificidades cognitivas das pessoas com deficiência visual.

Neste sentido, existem diversos recursos tecnológicos cuja função é garantir às pessoas com deficiência a possibilidade de realizar certas ações ou, então, de ter acesso à determinadas informações. Por exemplo, uma bengala especial auxilia o cego a evitar obstáculos baixos e a identificar variações nos tipos de piso para que ele possa se locomover com autonomia em qualquer área de circulação. Já no caso de uma pessoa com baixa visão, uma lupa pode auxilia-la na leitura de uma revista. Recursos deste tipo são chamados de ajudas técnicas ou tecnologias assistivas.

De acordo com Cecatto (2006), a tecnologia assistiva é definida como

...qualquer item, peça de equipamento ou sistema de produtos, adquirido comercialmente ou desenvolvido artesanalmente, produzido em série, modificado ou feito sob medida, que é usado para manter ou melhorar as habilidades de pessoas com limitações funcionais, sejam físicas ou sensoriais. (p. 32)

Para as pessoas com deficiência visual, o uso de tecnologias é muito importante na área da aprendizagem. Existem diversos produtos elaborados especialmente para garantir a 
acessibilidades destas pessoas às coisas que são comuns a todos, como os softwares de sintetização de voz, o áudio-livro, a máquina-braille, etc.

Entretanto, existem alguns recursos que não podem ser precisamente classificados como tecnologias assistivas, como, por exemplo, o sistema Braille. Apesar de ser um recurso tecnológico, o sistema Braille não é exatamente uma peça, um item ou um produto, e sim um sistema de códigos utilizado para a leitura e escrita para pessoas cegas. Portanto, ao longo deste trabalho será utilizado o termo recurso técnico que, no entendimento do autor, é mais abrangente e representa melhor os materiais e recursos utilizados para facilitar os processos de aprendizagem das pessoas cegas.

O sistema Braille é, certamente, um dos recursos mais conhecidos na educação de cegos. Este sistema foi desenvolvido por Louis Braille por volta de 1837, e consiste em um agrupamento de pontos táteis capazes de representar todas as letras do alfabeto, números, símbolos e sinais matemáticos, fonética e musicografia (Oliveira, 2009). A unidade básica da escrita Braille é chamada de célula, uma matriz que permite uma combinação de até seis pontos para a formação dos sinais gráficos.

Durante o processo educacional, grande parte da atividades específicas para crianças com deficiência visual - principalmente as que possuem cegueira - estimulam o uso do tato. Em um interessante manual com brinquedos e jogos específicos para crianças cegas ou com baixa visão, Siaulys (2005) apresenta uma grande quantidade de atividades que desenvolvem a percepção tátil e os outros sentidos. O manual é organizado com atividades que correspondem às diferentes fases da infância. Nota-se que os brinquedos e jogos para crianças em idade escolar, principalmente no período de alfabetização, são predominantemente táteis e utilizam o sistema Braille, com o objetivo familiarizar a criança cega com o uso deste sistema.

Para o ensino de matemática o recurso mais utilizado é o sorobã , um instrumento de origem oriental, semelhante ao ábaco. O instrumento possui um conjunto de contas que são dispostas em colunas verticais e paralelas com as quais é possível realizar todo tipo de operação matemática.

Ao longo do processo de escolarização da pessoa cega, surgem muitos conteúdos em que a utilização de recursos técnicos é necessária para que o aluno tenha acesso às informações que são fundamentais para a aprendizagem. Por exemplo, em geografia os mapas precisam ser codificados para o relevo, de forma que possam ser percebidos pelo tato. $\mathrm{O}$ 
mesmo ocorre com as figuras geométricas em matemática, com a genética em biologia, como o conceito de molécula em química, etc. Nestes casos os educadores criam diferentes formas de representar os conceitos, e frequentemente buscam criar figuras táteis que representam estes conceitos, seja pela construção de maquetes, miniaturas ou desenhos.

Por isso, o trabalho com figuras em relevo e com a percepção tátil de réplicas que representam objetos de larga escala, é importante para desenvolver habilidades que preparem os sujeitos para a utilização de recursos técnicos na aprendizagem de conceitos científicos.

Entretanto, os recursos gráficos ainda representam um tema controverso em relação à sua efetividade. Muitos especialistas questionam se as figuras, ou ilustrações, em relevo são de fácil entendimento para os cegos (Cardeal, 2009). Ou seja, será que os elementos que constituem as figuras são percebidas como correspondentes do objetos reais que elas representam? As ilustrações são de fácil reconhecimento para o cego?

Estas perguntas são pertinentes, uma vez que uma figura não pode ser considerada adaptada para o cego apenas por ser uma transposição da tinta para o relevo. Um desenho pode conter tantos detalhes, que sua percepção pelo tato torna-se confusa. Neste sentido, Espinosa e Ochaíta (2004) alertam que o tato "permite uma coleta da informação bastante precisa sobre os objetos próximos, mas é muito mais lento que a visão e, por isso, a exploração dos objetos grandes é fragmentária e sequencial” (p. 151). A mesma dificuldade apontada por estas autoras pode ser aplicada a percepção de desenhos táteis muito grandes ou com muitos detalhes. Sendo assim, a utilização de desenhos táteis

Cardeal (2009) realizou uma pesquisa com o objetivo de verificar a representatividade de ilustrações táteis para as pessoas cegas. Em seu estudo, a autora investigou se as ilustrações em relevo de obras de literatura infantil eram facilmente reconhecidos por crianças e adolescentes portadores de cegueira congênita. Os resultados demonstraram que, para que os desenhos sejam reconhecidos, são fundamentais a esquematização da forma e a experiência com desenho (p. 128). Ou seja, é preciso que as ilustrações táteis obedeçam a algumas condições específicas que facilitam o seu reconhecimento, quais sejam: linha de contorno bem definida; forma esquemática; repetição da forma ao longo da leitura e forma simplificada (sem detalhes). Além disso, os sujeito que já tinham experiência com a realização de desenhos em relevo apresentaram maior facilidade no reconhecimento de desenhos com esquemas similares àqueles já produzidos por eles. 
O interesse em conhecer as contribuições de recursos como estes, levou o autor do presente trabalho a investigar a utilização de um recurso técnico, o desenho em relevo, na aprendizagem de conceitos por crianças cegas. 


\section{CAPÍTULO 3}

\section{JUSTIFICATIVA E OBJETIVOS}

\subsection{Justificativa}

Nunes (2004) verificou em seu estudo que a cegueira parece não impedir a utilização de atributos definidores no processo de formação de conceitos. Mesmo os conceitos que não têm exemplos tateáveis, como nuvem ou lua, foram definidos a partir de informações verbais transmitidas por pessoas videntes. No entanto, a autora chama a atenção para a necessidade de utilizarem-se adaptações para as situações em que os atributos definidores não são percebidos, em função da falta da visão. Algumas vezes a pessoa cega pode encontrar dificuldades em definir corretamente um conceito, pois as informações necessárias para defini-lo são predominantemente visuais. Em sua dissertação de mestrado, a autora utilizou uma história envolvendo regras de um jogo de cartas para verificar se os sujeitos cegos tinham o conceito "trapaça", e verificou que muitos tiveram dificuldade em entender a história adequadamente pela falta de experiência com os jogos de cartas, que costumam basear-se em trocas de informações visuais (as cartas, a comunicação entre os jogadores, etc.). Este exemplo demonstra que não se trata de incapacidade em conhecer ou praticar o jogo, mas que o mesmo não costuma ser cognoscível ao cego. No entanto, existem meios para tornar um baralho acessível, o que resolveria o problema.

Neste sentido, Batista (2005) afirma que a criança cega pode ter algumas especificidades no processo de aquisição de conceitos e, portanto, é preciso construir "recursos auxiliares na compreensão de diferentes conceitos e sistemas de conceitos”(p. 14).

Ainda que existam muitos recursos técnicos para facilitar a aprendizagem da criança cega, são escassos os trabalhos científicos que exploram os processos psicológicos e cognitivos decorrentes do uso de recursos tecnológicos na aprendizagem, principalmente na área da aquisição de conceitos. 


\subsection{Objetivos}

O objetivo desta pesquisa é investigar os efeitos da utilização de um recurso técnico, o desenho em alto relevo, no processo de aquisição e reconhecimento de conceitos por crianças com deficiência visual. Tal objetivo será explorado em dois aspectos:

a) verificar se este recurso técnico é eficiente na tarefa de transformar conceitos visuais não tateáveis, ou que possuem estímulos que não são possíveis de serem apreendidos pelos sentidos das pessoas cegas, em acessíveis;

b) identificar mudanças significativas na percepção dos atributos definidores destes conceitos após treinamento com o recurso técnico. 


\section{CAPÍTULO 4}

\section{MÉTODO}

\subsection{Sujeitos}

Participaram da pesquisa cinco crianças e adolescentes com cegueira, sendo quatro do sexo masculino e uma do sexo feminino, na faixa etária de oito a 17 anos, que corresponde à idade esperada para a cursar o Ensino Fundamental e Médio no sistema educacional brasileiro. Desses sujeitos, três eram portadores de cegueira congênita e dois de cegueira adquirida. Todos os sujeitos estavam matriculados em escolas da rede pública (estadual) da cidade de São Paulo, no ensino regular.

Os nomes verdadeiros dos sujeitos não serão revelados por motivos éticos, portanto serão utilizados nomes fictícios para sua identificação ao longo deste trabalho.

O primeiro sujeito, identificado pelo nome Vítor, tem 9 anos e está cursando a $3^{\text {a }}$ série do Ensino Fundamental I. Nasceu com glaucoma nos dois olhos, fez cirurgia aos dois anos, quando houve o descolamento da retina do olho esquerdo. De acordo com o sujeito, até os sete anos de idade teve resíduo visual que o permitia perceber formas e cores. No entanto a perda visual foi progressiva desde o nascimento, até que aos sete anos ficou cego. Atualmente possui um pouco de percepção de luz. Foi alfabetizado em Braille e utiliza a máquina-braile para escrever. Tinha noções básicas de desenho, mas no pré-teste demonstrou dificuldade no manuseio do material de desenho.

O segundo sujeito é identificado pelo nome Rogério, de 12 anos. Está cursando a $3^{\text {a }}$ série do Ensino Fundamental I. Recebeu o diagnóstico de glaucoma em ambos os olhos logo após o nascimento. Teve uma série de complicações relacionadas ao glaucoma, por isso sua família teve dificuldades em mantê-lo na escola. Ficou cego no começo do ano em que foi realizado esta pesquisa Até então, possuía baixa visão. É alfabetizado e utiliza o Braille para escrita, com auxílio da máquina-braille. Demonstrou-se familiarizado com a confecção de desenhos.

O terceiro sujeito é identificado pela nome Daniela, de 12 anos. Está cursando a $2^{\mathrm{a}}$ série do Ensino Fundamental I. Possui cegueira congênita, com o diagnóstico de retinopatia da 
prematuridade. É alfabetizada, utiliza o Braille para a escrita, com auxílio da máquina-braille. Possui familiaridade com desenhos, no começo do ano começou a ter aulas de pintura.

O quarto sujeito tem 15 anos, identificado pelo nome Bruno. Está cursando o primeiro ano do Ensino Médio. É cego congênito, com o diagnóstico de retinopatia da prematuridade. Foi alfabetizado com a utilização do Braille, sendo que utiliza a máquina-braille para a escrita. Demonstrou familiaridade com a utilização inicial dos desenhos.

O quinto sujeito foi identificado com o nome Fábio. Tem 17 anos e está cursando o primeiro ano do Ensino Médio. É cego congênito, diagnosticado com retinopatia da prematuridade. Foi alfabetizado pela escrita Braille, e utiliza a máquina-braille para a escrita. Demonstrou familiaridade com a confecção de desenhos e a utilização do material de desenho.

\subsection{Material}

Os materiais que foram utilizados durante as etapas da pesquisa foram:

- Gravador eletrônico de áudio.

- Filmadora.

- Fichas de identificação dos participantes: dados pessoais e escolares do participante (anexo A).

- Kit de desenho para cegos: consiste em um conjunto com uma prancha de madeira, revestida por uma tela vazada e quadriculada. Acompanha uma caneta com ponta de metal e outros materiais para desenho geométrico que não foram utilizados. O kit utilizado é importando da Espanha, e difere daquele que é comumente utilizado em São Paulo (a prancha para desenho é emborrachada).

- Papel sulfite tamanho A4.

- Oito desenhos em relevo, feitos com o kit de desenho, representando um conceito cada: girafa, nuvem, montanha, árvore, leão, trem, prédio e ilha (anexo B). Os modelos dos desenhos foram extraídos do programa de computador Boardmaker, comumente utilizado para composição símbolos que compõem pranchas de comunicação para pessoas com 
paralisia cerebral. Este material foi escolhido por conter imagens que representam bem os conceitos, e são formados por traços relativamente simples, que foram fáceis de passar para o relevo.

\subsection{Procedimento}

\subsubsection{O contato com as escolas}

Foram procuradas escolas da rede estadual de ensino que atendem alunos com deficiência visual (cegueira, especificamente) e instituições especializadas no atendimento a pessoas com deficiência visual.

O contato com as Escolas da Rede Estadual foi feito a partir do Centro de Apoio Pedagógico Especializado (CAPE), órgão que assessora as escolas da rede e possui cadastro de todos os alunos com algum tipo de deficiência. Foi escolhida uma escola que possui sala de recursos para alunos com deficiência visual, na qual estudam 5 alunos cegos.

Foram contatadas a diretora e a professora da sala de recursos para alunos com deficiência visual, sendo apresentado a cada os objetivos e o procedimento da pesquisa. Além disso, foi apresentada a carta de consentimento livre e esclarecido, que foi assinada prontamente pela diretora.

Paralelamente ao contato com a escola estadual, foram buscadas instituições especializadas no atendimento de crianças com deficiência visual.

Na cidade de São Paulo existem poucas instituições especializadas no atendimento de pessoas cegas e cada uma possui características específicas. De maneira geral, estas instituições realizam atendimento direto nas áreas de reabilitação, saúde, educação e assessoria técnica. Esta última corresponde aos serviços de construção de materiais especializados para pessoas com deficiência visual, como áudio-livros, impressão de livros escolares em Braille e outros. Além disso também orientam instituições públicas e privadas para adaptação de espaços físicos e acesso a serviços.

No entanto, dificilmente estas instituições oferecem escolarização formal, embora ofereçam atendimentos educacionais individualizados e cursos livres para adolescentes e adultos. Tal fato dificultou a busca por participantes da pesquisa, devido a alta rotatividade de 
pessoas durante um período diário nessas instituições e o pouco tempo que elas permanecem (comparecem para atendimentos específicos) durante cada visita. Como a pesquisa implicava em um número considerável de encontros, a exigência de comparecer a um atendimento e depois participar da pesquisa não atraiu aos potenciais participantes.

Ao todo, foram contatadas três instituições especializadas no atendimento de pessoas com deficiência visual. Uma carta de apresentação do pesquisador, contendo a confirmação de seu vinculo com a Universidade de São Paulo e os objetivos do trabalho foi apresentada a todas as instituições. Em duas delas não havia sujeitos que correspondessem aos critérios de participação dessa pesquisa, e a terceira não aceitou participar.

O contato com cada uma das instituições foi proveitoso para a refletir sobre a realidade dos serviços oferecidos às pessoas com deficiência visual, mas não resultou em sujeitos que pudessem participar desta pesquisa científica. A seguir, serão apresentadas algumas situações que chamaram a atenção deste pesquisador:

Em todas as instituições a maioria das pessoas com deficiência visual possui baixa visão e, dentre os que são cegos, poucos são congênitos.

O uso de desenho em relevo é algo frequente. Na impressão de livros e materiais didáticos em Braille, todas as ilustrações, gráficos e mapas são passados para relevo. Na instituição que oferece escolarização formal, o trabalho com desenhos em relevo é utilizado nas mais variadas disciplinas, notadamente em artes, matemática, geografia e ciências. Ainda assim, existe um certo consenso de que o desenho é algo difícil de ser apreendido pelo cego congênito, mas que tem o papel de enriquecer a experiência de aprendizagem.

Alguns desenhos são bastante detalhados e planejados. Por exemplo: o desenho de uma figura geométrica em um livro de matemática, como uma pirâmide, possui diferentes traçados em relevo para demonstrar suas características tridimensionais. O mesmo tipo de recurso é utilizado para plantas arquitetônicas, com objetivo de demonstrar às pessoas cegas as nuances entre os espaços. Embora a técnica seja apurada, ela é criticada por profissionais da área de educação para pessoas com deficiência visual pelo pouco valor prático que apresenta a seu público alvo. 
Embora o desenho seja um recurso presente em materiais didáticos e métodos de ensino, sua eficácia nos processos de aprendizagem não é clara.

\subsubsection{Seleção dos alunos participantes}

Encontrar estudantes cegos na rede pública de ensino e nas instituições especializadas não foi tarefa fácil. Havia a expectativa de que tais instituições funcionassem como unidades centralizadoras, devido aos serviços que oferecem. No entanto, diversas barreiras foram encontradas para o contato e a seleção dos participantes da pesquisa.

Duas, das três instituições contatadas, tem como procedimento realizar por conta própria a seleção dos sujeitos com perfil correspondente à pesquisa e entrar em contato com as famílias para verificar a disponibilidade. No entanto, não foi possível encontrar sujeitos dentro do perfil ou com disponibilidade. A terceira instituição, uma escola especializada, realizou a seleção dos alunos de acordo com o perfil, mas não se propôs a efetuar - e nem permitiu que o pesquisador - o contato com as famílias. Além disso, estipulou o limite de apenas dois encontros com cada aluno, número insuficiente para o coleta de dados relevantes para o objetivo do trabalho. Como tais exigências não puderam ser aceitas pelo pesquisador, os eventuais sujeitos nela matriculados não puderam fazer parte desta pesquisa.

Uma vez realizado o contato com a escola estadual, e certificada a presença de alunos com deficiência visual na mesma, foram selecionados e convidados os discentes a participar da pesquisa. Os alunos foram selecionados de acordo com os seguintes critérios: a) possuir deficiência visual; b) não ter outra deficiência além da visual; c) não ter qualquer tipo de doença ou transtorno que influencie a aprendizagem; d) ter aproximadamente entre 6 e 18 anos; e) estar alfabetizado e f) estar familiarizado com o uso do Braille para escrita.

Os alunos participantes da pesquisa fazem parte da sala de recursos da escola. A sala de recursos consiste em um atendimento pedagógico especializado, que recebe o aluno com necessidades educacionais especiais no contra-turno da classe comum na qual está matriculado. Naturalmente, tratava-se de uma sala de recursos para alunos com deficiência visual. 


\subsubsection{Consentimento}

A partir do levantamento dos alunos voluntários, foi realizado o contato com os pais ou responsáveis e explicado a cada um deles o propósito e os procedimentos da pesquisa, e também foram apresentados os termos de consentimento livre e esclarecido (anexo C) para a assinatura.

\subsubsection{Contato com os participantes}

Acertadas todas as providências preliminares, o pesquisador conversou com todos os alunos antes da realização do pré-teste para que todos eles pudessem estar cientes do que seria feito daquele momento em diante. Nem todos os alunos frequentam a sala de recursos no mesmo dia e horário, portanto a conversa preliminar foi feita com os alunos em momentos diferentes, tanto individual como coletivamente.

Quando em contato com o aluno participante, foram explicados os objetivos do encontro e da pesquisa, aproximadamente desta maneira: Sou estudante de pós-graduação em psicologia e estou interessado em conhecer como crianças com deficiência visual aprendem certas coisas. Para isto preciso da colaboração de vocês em algumas atividades que vou propor. A participação de vocês é voluntária e vocês podem perguntar o que sentirem vontade antes de continuar. Desde já agradeço a colaboração sua colaboração!

\subsubsection{Delineamento experimental}

\subsubsection{Pré-teste}

Cada sujeito foi entrevistado individualmente pelo pesquisador durante um período de 30 minutos na própria sala de recursos, no período de aula do aluno. O material utilizado foi: gravador de áudio para as respostas verbais, figuras desenhadas com pontos em relevo com exemplos dos conceitos, papel sulfite A4, desenhador e lapiseira com ponta de metal para marcar os pontos em alto relevo. O participante e o pesquisador utilizaram as mesas e cadeiras de estudantes presentes na sala. Além disso, cada participante teve uma pasta para o armazenamento do seu material e a ficha de identificação com os dados pessoais e carta de consentimento livre e esclarecido. 
Primeiramente foi brevemente explicado ao sujeito o objetivo e procedimento do teste: Gostaria de verificar o que você conhece a respeito de algumas coisas. Para isto irei fazer algumas perguntas, mostrarei alguns desenhos feitos em pontos e pedirei que você faça alguns desenhos utilizando os pontos em alto relevo, como no Braille. Não se preocupe com erros ou acertos, quero que você me mostre como você faz.

A orientação descrita acima é apenas uma aproximação do que foi dito e pôde ser alterado em sua forma dependendo da compreensão que o sujeito apresentou ou dos questionamentos que o mesmo fez.

Uma vez que os esclarecimentos iniciais foram encerrados, deu-se início à testagem com a nomeação dos conceitos e a solicitação de sua definição. Foi feita ao sujeito, oralmente, a seguinte pergunta: Poderia me dizer o que é X? No lugar de $\mathrm{X}$ estava, naturalmente, o conceito a ser avaliado. Nos casos em que o sujeito demorou emitir a resposta, o pesquisador repetiu a pergunta, ou modificou sua forma, a fim de assegurar a compreensão por parte do participante. Sempre que a resposta do participante gerava qualquer tipo de dúvida para a compreensão do pesquisador, o mesmo efetuou mais perguntas a fim de esclarecer a resposta do entrevistado.

Em um segundo momento, foi apresentado aos participantes uma série de figuras, desenhadas por pontos em relevo, que eles exploraram pelo tato e tentaram descobrir o que estava representado. O procedimento foi iniciado pelo pesquisador com o devido esclarecimento da tarefa: Agora irei lhe mostrar alguns desenhos feitos com pontos em alto relevo. Sua tarefa é dizer o que o desenho parece ser. Não se preocupe se sua resposta está correta, o importante neste momento é saber o que você acha que o desenho é. Quando considerou necessário, o pesquisado pediu para o participante justificar ou explicar a sua resposta. A ordem da apresentação de cada desenho foi pré-estabelecida pelo pesquisador e manteve-se a mesma para todos os participantes.

Finalmente, o participante foi solicitado a desenhar os conceitos que procurou definir ou reconhecer. As orientações transmitidas pelo pesquisador foram as seguintes: Agora nós vamos fazer desenhos utilizando os pontos em alto relevo. Aqui o desenhador, a caneta e o papel. Eu vou the dizer o que deve desenhar. Tente desenhar a forma que lhe vem à mente quando eu lhe disser o que deve ser desenhado. Use o tempo que precisar. O pesquisador fez as perguntas que considerou necessárias a fim de conhecer os processos que 
guiaram as ações do sujeito, principalmente nos casos em que o desenho era pouco semelhante à forma convencional (ou visual) de representar o conceito.

A produção dos desenhos encerrou a etapa do pré-teste. Ao agradecer à participação do sujeito, o pesquisador perguntou se o sujeito tinha interesse em encontrar-se mais vezes para desenvolver melhor a técnica do ponto em relevo para fazer e reconhecer desenhos. Todos concordaram e continuaram a participação na pesquisa.

As entrevistas foram transcritas e os desenhos copiados em formato eletrônico (anexo D).

\subsubsection{Treinamento}

A partir da avaliação dos conceitos, foi organizado um programa de treinamento para a aprendizagem dos referidos dos mesmos. O programa foi desenvolvido em três encontros, realizados nas escolas em sessões semanais. O treinamento foi realizado na escola em que os alunos estudavam, dentro da sala de recursos e junto aos demais colegas e professora.

Para ensinar os conceitos, foi utilizada a técnica do ponto em alto relevo, que consiste em construir exemplos do conceito com pontos em relevo, tanto para a produção quanto para

o reconhecimento do mesmo. É importante ressaltar que o treinamento para uso do ponto visou desenvolver nos participantes novas maneiras de utilizar a técnica, não relacionadas com a escrita, mas para representar conceitos.

$\mathrm{Na}$ primeira sessão cada sujeito foi instruído em relação à utilização do material de desenho, foram dados esclarecimentos sobre objetivos do treinamento e puderam explorar livremente o material (papel, caneta e prancha de apoio). A proposta foi proporcionar ao sujeito um tempo de familiarização com a realização de desenhos em relevo.

Todos os sujeitos já haviam feito desenhos em relevo, mas utilizando materiais diferentes. Sendo assim, a primeira sessão serviu para trabalhar a melhor maneira para segurar a caneta, aprender a posicionar o papel na prancha e praticar a movimentação para a obtenção de diversos tipos de traçado (reto, curvo, ondulado, circular, etc).

Outro aspecto importante foi a questão da verificação que os sujeitos faziam sobre os traços que marcavam no papel. Enquanto uma das mãos segurava e movia a caneta, a outra 
acompanhava a marca deixada no papel, permitindo que o sujeito pudesse se localizar no desenho que fazia. Como se pode imaginar, as marcas mais fortes ficam impressas no verso da folha, uma vez que a tela fica localizada sob o papel. Mesmo assim, na parte da frente do papel o traço fica marcado, é uma impressão funda que pode ser percebida pelo cego e que se mostrou eficiente.

Após explorar o material, os sujeitos realizaram desenhos de dois dos conceitos que estiveram presentes no pré-teste: girafa e nuvem. Como a preocupação não foi com a estética do desenho, mas com a qualidade da representação, adotou-se a mesma sequência de desenhos do pré-teste, independente do desenho ser mais simples ou mais complexo do ponto de vista estético.

Foram apresentados aos sujeitos os dois desenhos - girafa e nuvem - feitos pelo pesquisador para que pudessem tatear. Paralelamente, o pesquisador descrevia a figura, com maior destaque para os atributos definidores do conceito. Sendo assim, além do recurso tátil a linguagem verbal também foi utilizada para que os sujeitos pudessem aprimorar suas definições dos conceitos.

Aqui o trabalho não é exclusivamente dedicado ao uso do ponto, mas também à complexidade das construções mentais a respeito dos mesmos. Por isso, os conceitos foram também explorados verbalmente, a fim de construir definições mais completas que permitissem a representação concreta com o ponto. Sendo assim, o pesquisador buscou verbalizar a forma dos conceitos concretos não tateáveis para os cegos. Neste momento, o reconhecimento de conceitos por meio de desenhos em pontos esteve associado ao uso da descrição verbal ou escrita do mesmo. Sabia-se que seria difícil para o sujeito cego captar o objeto representado pelo desenho apenas pelo toque, portanto uma descrição dos traços presentes no papel direcionou de maneira mais efetiva a exploração do desenho.

Depois de tatear a figura, e comentar sobre ela, os sujeitos realizaram os desenhos da girafa e da nuvem, nesta ordem. O tempo médio estipulado para esta sessão foi de 30 minutos.

Nas duas sessões seguintes foram trabalhados três conceitos em cada uma delas, seguindo a sequência do pré-teste. Dependendo da necessidade do sujeito, foram retomados os exercícios de traçado, como desenhar linhas retas, onduladas, figuras geométricas simples, etc. A exemplo da primeira sessão, as duas seguintes também tiveram duração média de 30 minutos. 
Infelizmente em nenhum dos casos foi possível manter o espaço de uma semana entre uma sessão e outra. Foram diversos os contratempos que os alunos e seus responsáveis tiveram, que os impediram de comparecer às aulas e a, consequentemente, participar da pesquisa dentro do cronograma previsto inicialmente.

\subsubsection{Pós-teste}

Ao final das sessões de treinamento, os sujeitos que participaram foram reavaliados em relação aos mesmos conceitos apresentados no pré-teste, para verificar a efetividade do programa em relação aos conceitos e à utilização da técnica como ferramenta de aprendizagem de conceitos.

Assim como no pré-teste, cada entrevista durou aproximadamente 30 minutos de tempo previsto para cada participante. No entanto este tempo variou de acordo com o sujeito, sendo que a sessão mais longa demorou pouco mais de 60 minutos. As entrevistas foram individuais e realizada na sala de recursos, durante o período de aula e em dias diferentes para cada participante.

Inicialmente foi solicitado ao sujeito que definisse verbalmente, e da maneira mais completa possível, os conceitos enunciados pelo pesquisador. As instruções foram idênticas à etapa do pré-teste. $\mathrm{O}$ pesquisador efetuou as perguntas que julgou necessárias para melhor esclarecimento sobre o que os sujeitos expressavam.

Ao final de cada definição verbal o sujeito fez um desenho correspondente ao conceito em questão. Portanto, esta etapa diferiu um pouco do pré-teste, pois os sujeitos fizeram os desenhos logo após as definições verbais correspondentes.

Terminado o último desenho de cada sujeito, dava-se por encerrada a etapa do pósteste. O pesquisador agradeceu a participação dos alunos voluntários pela importante colaboração com a sua pesquisa.

As definições verbais foram transcritas e os desenhos copiados em formato eletrônico (anexo D). 


\section{CAPÍtULO 5}

\section{RESULTADOS}

\subsection{Juízes}

$\mathrm{Na}$ avaliação das definições verbais e dos desenhos realizados pelos sujeitos, no pré e pós-testes, foram considerados dois aspectos: o aprimoramento das definições verbais e o aumento da representatividade dos desenhos em relação aos conceitos, pela utilização do desenho em relevo.

Foram utilizados três juízes para a avaliação dos dados coletados. Adotou-se um número ímpar de juízes a fim de evitar eventuais situações de empate ou impasse.

Os juízes receberam, como material para análise, a transcrição de todas as definições verbais das etapas de pré e pós-teste, bem como os desenhos realizados pelos sujeitos nestas mesmas etapas. Todo este material foi dividido pelos conceitos pesquisados, formando, ao todo, oito conjuntos com definições verbais e conceitos.

Cada conjunto, correspondente a um conceito, foi acompanhado de uma tabela de avalição na qual os juízes atribuíram os valores aos materiais avaliados (anexo E). Sendo assim, cada juiz recebeu oito conjuntos, referentes aos oito conceitos, com uma tabela de avaliação.

Nas tabelas de avaliação dos juízes estavam arrolados todos os 5 sujeitos que participaram da pesquisa, juntamente todas as definições verbais e todos os desenhos das etapas de pré e pós-teste.

A fim de reduzir possíveis interferências no julgamento dos juízes, nenhum dos dados sobre os sujeitos ou sobre a etapa na qual o material foi produzido foram revelados. Para isso, foram atribuídos códigos a estes materiais, por meio dos quais apenas o pesquisador podia identificar o sujeito que emitiu a definição verbal e que realizou o desenho, assim como a etapa correspondente ao material em análise (pré ou pós-teste).

Dessa maneira, cada definição verbal e cada desenho foi identificado com um código, composto por: 1 letra, 1 número, os sinais “.” ou “-”, e mais duas letras. Cada código 
corresponde a uma definição verbal e um desenho, que representam o mesmo conceito, como pode ser visto na Figura 2.

\begin{tabular}{|c|c|c|c|c|}
\hline \multicolumn{5}{|c|}{ GIRAFA } \\
\hline Sujeito & Definição verbal & observaçes & Desenho & observaçōes \\
\hline N1.GH & & & & \\
\hline S1.MP & & & & \\
\hline N1-vc & & & & \\
\hline S1-Xs & & & & \\
\hline H1.UL & & & & \\
\hline
\end{tabular}

Figura 1 - Exemplo da tabela de avaliação utilizada pelos juízes.

Ao todo, foram criados dez códigos que representam cinco sujeitos nas etapas de pré e pós-teste. A sequência dos códigos obedeceu a uma alternância das etapas e os sujeitos. Isto pode ser observado, por exemplo na figura acima. A primeira letra representa o sujeito, o "., significa pré-teste, e o “-” pós-teste.

Os juízes foram escolhidos dentre os psicólogos conhecidos pelo pesquisador. Os psicólogos deveriam ter alguma proximidade com a psicologia da aprendizagem, com educação ou com educação especial.

A juíza 1 é psicóloga, vidente, mestranda em Educação: História, Política e Sociedade pela PUC-SP. Desenvolve sua pesquisa na área de inclusão educacional de pessoas com deficiência É professora de Psicologia do Desenvolvimento para o curso de graduação em Psicologia em uma faculdade particular da cidade de São Paulo. Possui experiência em educação especial e inclusiva. Além disso, atua como psicoterapeuta infantil.

A juíza 2 é psicóloga, vidente, mestranda em Educação: História, Política e Sociedade pela PUC-SP. Desenvolve pesquisa sobre a utilização de tecnologias no processo educacional. Atua como psicóloga clínica de adolescentes e adultos.

O juiz 3 é psicólogo, cego adventício, Mestre em Psicologia Comportamental pela PUC-SP e Doutor em Educação pela USP. É especialista em educação de crianças com 
deficiência visual. Atua nos serviços de educação especial do estado de São Paulo e presta consultoria para projetos de educação inclusiva.

As juízas 1 e 2 receberam todo o material impresso, incluindo os desenhos, que foram copiados em um scanner. Para que o desenho ficasse visível, o pesquisador passou giz pastel na cor preta nas linhas em relevo. O juiz 3 recebeu as folhas de avaliação e as definições verbais em arquivos no formato .doc, que podem ser lidos por softwares de sintetização de voz. Para este juiz foram entregues os desenhos originais, para possibilitar o uso do tato na avaliação.

É importante destacar que, para garantir a compreensão dos desenhos pelo juiz 3, o pesquisador acompanhou o juiz na avaliação dos desenhos, com a função de descrevê-los verbalmente enquanto eram explorados pelo tato.

\subsection{Análise dos resultados por conceitos}

Nesta etapa procurou-se avaliar as mudanças globais que ocorreram nas definições e representações gráficas dos conceitos após o período de treinamento. A partir da comparação das respostas e desenhos anotadas no pré e pós-teste, foram identificadas as mudanças ocorridas entre estas duas etapas.

Foi utilizada uma escala ordenada de 1 a 5, a fim de avaliar a correção da definição e a qualidade do desenho que representa o conceito e de reduzir uma possível arbitrariedade na compreensão da melhoria do mesmo. Os juízes assinalaram os valores nas definições e nos desenhos que representaram os conceitos pesquisados de acordo com a escala. Nesta tabela havia uma legenda com o critério correspondente a cada valor, no qual 1 representava uma definição muito ruim e 5 uma definição muito boa.

Na primeira coluna da tabela estão relacionados os sujeitos, na segunda e terceira estão as médias aritméticas das notas atribuídas pelos três juízes ${ }^{5}$, respectivamente, no pré e pós-teste das definições verbais. Na quarta coluna é mostrada a diferença percentual do desempenho nas definições verbais. A quinta e sexta colunas agrupam as médias de pré e pós teste relacionados à avaliação dos desenhos, sendo a última coluna reservada às diferenças

\footnotetext{
${ }^{5}$ As notas atribuídas por cada juiz podem ser verificadas no anexo $\mathrm{F}$.
} 
percentuais das médias na avalição de cada desenho. Na última são apresentadas as médias gerais das avaliações de cada sujeito, relativas aos conceitos que intitulam as tabelas.

Cabe advertir que no caso específico deste trabalho, em face do reduzido número de sujeitos e da grande dispersão dos resultados, as médias gerais não devem ser consideradas como um indicativo confiável do desempenho dos sujeitos. Ela permite apenas uma visão e muito geral das mudanças no desempenho. O pequeno número de sujeitos e a grande variabilidade podem distorcer o que realmente aconteceu, uma vez que uma nota individual muito alta ou muito baixa exerce grande influência sobre a média final.

Em função das limitações para a utilização das médias, como resultado confiável, decidiu-se analisar os dados de acordo com o progresso individual. Para isto calculou-se a diferença $^{6}$ entre a média do pré e do pós teste por sujeito e por conceito. Acredita-se que a diferença percentual entre as médias do pré e pós-teste de cada sujeito é o dado, ou o índice, que melhor expressa a mudança na representação dos conceitos avaliados.

A seguir, serão apresentadas as tabelas que permitem uma apreciação sobre como cada conceito foi representado, tanto em definições verbais como em desenhos. Também é possível verificar quais conceitos foram melhor dominados e aqueles nos quais os sujeitos apresentaram maior dificuldade.

No cabeçalho de cada tabela encontram-se, na primeira linha, o nome do conceito avaliado. A segunda linha mostra a divisão das colunas em: sujeito, definição verbal, desenhos e média geral. Por fim, a terceira linha subdivide a coluna de definição verbal e a coluna de desenhos em pré-teste, pós-teste e diferença percentual.

\footnotetext{
6 Para o cálculo das diferenças percentuais adotou-se o valor da média do pré-teste. Portanto o progresso, ou regresso, do sujeito é analisado apenas em relação a si mesmo, e não ao valor máximo da escala, que corresponde a 5 .
} 
Tabela 1 - Conceito "Girafa”: avaliação da definição e o desenho pelos juízes.

\begin{tabular}{lcccccc}
\hline & \multicolumn{4}{c}{ Girafa } & \multicolumn{3}{c}{ Desenho } \\
Sujeito & Pré & Pós & Diferença em \% & Pré & Pós & Diferença em \% \\
\hline Vítor & 5 & 4,6 & -8 & 4,6 & 5 & 8,7 \\
Bruno & 4 & 3 & -25 & 2 & 2,3 & 15 \\
Daniela & 1,6 & 3,3 & 106,2 & 3,6 & 3 & $-16,7$ \\
Rogério & 3,3 & 3,3 & 0 & 3,6 & 3,3 & $-8,3$ \\
Fábio & 3,3 & 4,3 & 30,3 & 2,3 & 3,3 & 43,5 \\
\hline Média geral & $\mathbf{3 , 4}$ & $\mathbf{3 , 7}$ & & $\mathbf{3 , 2}$ & $\mathbf{3 , 3}$ & \\
\hline
\end{tabular}

A tabela acima representada mostra que, em relação às definições verbais do conceito "girafa", a média geral aumentou do pré para o pós-teste, de 3,4 para 3,7 pontos. Em relação aos desenhos, o aumento da média geral foi de 3,2 no pré-teste para 3,3 no pós-teste, ou seja, não houve, na média geral, mudanças significativas entre o desempenho dos sujeitos.

Daniela foi quem apresentou o aumento mais significativo nas notas de definição verbal, passando de 1,6 para 3,3, o que representa um aumento de 106,2\%. Em segundo lugar, Fábio teve aumento nas notas médias de 3,3 para 4,3, uma diferença correspondente a 30,3\%. Bruno e Vítor tiveram diminuição das médias, sendo que Bruno apresentou a queda mais significativa, de 4 para 3 pontos, uma redução de $-25 \%$. A redução de Vítor foi correspondeu a $-8 \%$, de 5 para 4,6 de média. Rogério manteve-se estável na definição verbal do conceito girafa, com 3,3 de média.

$\mathrm{Na}$ avaliação dos desenhos de "girafa", a média geral manteve-se praticamente estável, com 3,2 no pré-teste e 3,3 no pós-teste.

Individualmente, Fábio apresentou o aumento mais significativo de desempenho, passando de 2,3 para 3,3, o que representa uma evolução de 43,5\%. Em segundo lugar, Vítor obteve um crescimento de $8,7 \%$ do pré para o pós-teste, com médias de 4,6 e 5 pontos. Apesar da diferença negativa presente na definição verbal de "girafa", Bruno apresentou uma diferença positiva de $15 \%$, com média inicial de 2 pontos e final de 2,3. Para Daniela a média diminuiu de 3,6 para 3, ou seja, uma redução de $12 \%$. A média de Rogério teve redução de 0,3 pontos, de 3,6 no pré para 3,3 no pós teste, uma diferença equivalente a $\quad-8,3 \%$ no desenho do conceito "girafa". 
Tabela 2 - Conceito "Nuvem”: avaliação da definição e o desenho pelos juízes.

\begin{tabular}{lcccccc}
\hline & \multicolumn{3}{c}{ Nuvem } & \multicolumn{3}{c}{ Desenho } \\
Sujeito & \multicolumn{2}{c}{ Definição verbal } & Pré & Pós & Diferença em \% \\
\hline Vítor & 4 & 4,6 & 15 & 4,3 & 4,3 & 0 \\
Bruno & 4,3 & 3,6 & $-16,3$ & 4 & 3,6 & -10 \\
Daniela & 2 & 3,3 & 65 & 3 & 4,6 & 53,3 \\
Rogério & 3,3 & 4 & 21,2 & 2,3 & 4 & 73,9 \\
Fábio & 4,3 & 4,6 & 7 & 4,3 & 2,3 & $-46,5$ \\
\hline Média geral & $\mathbf{3 , 5}$ & $\mathbf{4}$ & & $\mathbf{3 , 5}$ & $\mathbf{3 , 7}$ & \\
\hline
\end{tabular}

Em relação às definições verbais do conceito "nuvem", apenas Bruno apresentou diminuição da média na definição verbal de "nuvem", com 4,3 no pré-teste e 3,6 no pós-teste, o que significa uma redução de $-16,3 \%$. Todos os demais sujeitos apresentaram aumento das médias e, consequentemente, da diferença percentual nas definições verbais. Daniela obteve o aumento mais significativo - 65\% - passando de 2 pontos no pré para 3,3 no pós-teste. Rogério aparece em segundo lugar, com o aumento de 3,3 para 4 pontos, o que aponta um aumento de 21,2\%. É seguido por Vítor, que passou de 4 para 4,6, com a diferença do pré para o pós-teste em 15\%. Fábio obteve médias 4,3 no pré-teste e 4,6 no pós-teste uma diferença positiva em $7 \%$.

Em relação aos desenhos de "nuvem”, Rogério e Daniela apresentaram mudanças significativas nas médias, sendo que o primeiro passou de 2,3 para 4 , um aumento de $73,9 \%$, e a segunda obteve uma diferença positiva de 53,3\%, passando de 3 para 4,6.

Por outro lado, Fábio apresentou uma queda significativa da média em relação ao desenho, com média 4,3 no pré-teste e 2,3 no pós teste. Esta queda de dois pontos equivale a diferença de $-46 \%$. Bruno também apresentou queda na média de seus desenhos, de 4 para 3,6 , o que corresponde a $-10 \%$. As médias de Vítor permaneceram estáveis, no valor de 4,3 pontos. 
Tabela 3 - Conceito "Montanha": avaliação da definição e o desenho pelos juízes.

\begin{tabular}{lcccccc}
\hline & \multicolumn{4}{c}{ Montanha } & \multicolumn{3}{c}{ Desenho } \\
Sujeito & Pré & Pós & Diferença em \% & Pré & Pós & Diferença em \% \\
\hline Vítor & 4,3 & 4,6 & 7 & 5 & 5 & 0 \\
Bruno & 2,6 & 3,3 & 26,9 & 1,3 & 2 & 53,8 \\
Daniela & 1 & 1,3 & 30 & 3,6 & 3,3 & $-8,3$ \\
Rogério & 3 & 4 & 33,3 & 3 & 4 & 33,3 \\
Fábio & 5 & 4 & -20 & 5 & 3,3 & -34 \\
\hline Média geral & $\mathbf{3 , 1}$ & $\mathbf{3 , 4}$ & & $\mathbf{3 , 5}$ & $\mathbf{3 , 5}$ & \\
\hline
\end{tabular}

A Tabela 3 mostra que, nas médias individuais de definição verbal, Rogério foi o sujeito que obteve o maior crescimento da média, de 3 para 4, o que representa $33,3 \%$ de melhora no desempenho. Bruno também aumentou sua média, de 2,6 para 3,3, ou seja, seu desempenho foi $26,9 \%$ melhor. A média de Daniela apresentou aumento de 30\%, com 1 no pré-teste e 1,3 no pós. As definições verbais de Vítor praticamente mantiveram-se estáveis, de 4,3 para 4,6. Neste caso, a diferença percentual é de $7 \%$ na qualidade da definição verbal de "montanha".

Apenas Fábio apresentou diminuição da média, de 4 para 5. Foi uma redução de $-20 \%$ na média.

No desempenho individual, em relação aos desenhos, Bruno teve o aumento mais significativo, com aumento de 1,3 para 2, uma diferença positiva de 53,8\%. Em seguida aparece Rogério com crescimento de 33,3\% nas médias, com 3 no pré teste e 4 na etapa do pós-teste, o mesmo aumento que obteve na avaliação da definição verbal deste conceito.

Por outro lado, em dois casos ocorreu diminuição das médias. A queda mais significativa aconteceu na média de Fábio, que obteve 5 no pré-teste e terminou com 3,3 no pós-teste, uma diminuição em -34\%. Já Daniela, obteve 3,6 no pré e 3,6 no pós-teste, uma diferença de $-8,3 \%$.

O único sujeito em que não houve mudança na média foi Vítor, que manteve 5 pontos. 
Tabela 4 - Conceito “Árvore”: avaliação da definição e o desenho pelos juízes.

\begin{tabular}{lcccccc}
\hline & \multicolumn{3}{c}{ Árvore } & \multicolumn{3}{c}{ Desenho } \\
Sujeito & Pré & Pós & Diferença em \% & Pré & Pós & Diferença em \% \\
\hline Vítor & 4,6 & 4,3 & $-6,5$ & 5 & 4 & -20 \\
Bruno & 4 & 4,6 & 15 & 1,3 & 2 & 53,8 \\
Daniela & 1,6 & 3 & 87,5 & 3,6 & 3 & $-16,7$ \\
Rogério & 3,3 & 4 & 21,2 & 4,6 & 3,3 & $-28,3$ \\
Fábio & 4,3 & 5 & 16,3 & 3,3 & 2,3 & $-30,3$ \\
\hline Média geral & $\mathbf{3 , 5}$ & $\mathbf{4 , 1}$ & & $\mathbf{3 , 5}$ & $\mathbf{2 , 9}$ & \\
\hline
\end{tabular}

Ao considerar o desempenho individual dos sujeitos na definição verbal de "árvore", nota-se que o aumento mais significativo ocorreu em Daniela, que obteve, inicialmente, 1,6 e aumentou sua média em $87,5 \%$, com 3 pontos no pós-teste. Rogério apresentou aumento em sua média, de 3,3 para 4, uma diferença de $21,2 \%$. O desempenho de Fábio foi, de acordo com a tabela, 16,3\% maior, com média 4,3 no pré e 5 no pós-teste. As médias de Bruno apresentaram diferença positiva de $15 \%$, com aumento de 4 para 4,6 pontos. Por outro lado, Vítor obteve média menor no pós-teste, 4,3, se comparada com os 4,6 pontos do pré-teste. A diferença é de $-6,5 \%$.

Em relação aos desenhos, Bruno foi o único com aumento da média, de 1,3 para 2, o equivalente a 53,8\% de melhora. Os demais sujeitos apresentaram diminuição das médias e, consequentemente, diferenças percentuais negativas. A redução mais significativa ocorreu com Fábio, cuja média passou de 3,3 para 2,3, o equivalente a -30,3, seguido por Rogério, que obteve queda de 4,6 para 3,3, diferença de -28,2\%. Em terceiro lugar está Vítor, cuja média no pré era 5 e mudou para 4 no pós-teste, ou seja, uma diferença de $-20 \%$. Para Daniela, o percentual da diferença entre as médias foi de $-16,6 \%$, com queda de 3,6 para 3 pontos.

Tabela 5 - Conceito “Trem”: avaliação da definição e o desenho pelos juízes.

\begin{tabular}{lcccccc}
\hline & \multicolumn{3}{c}{ Definição verbal } & \multicolumn{3}{c}{ Desenho } \\
Sujeito & Pré & Pós & Diferença em \% & Pré & Pós & Diferença em \% \\
\hline Vítor & 3,3 & 4 & 21,2 & 4,3 & 4,6 & 7 \\
Bruno & 4,6 & 4,6 & 0 & 3,6 & 4 & 11,1 \\
Daniela & 2,6 & 3,6 & 38,5 & 4,3 & 4,3 & 0 \\
Rogério & 4 & 4,3 & 7,5 & 3,3 & 4,6 & 39,4 \\
Fábio & 4,6 & 4,6 & 0 & 3,6 & 4 & 11,1 \\
\hline Média geral & $\mathbf{3 , 8}$ & $\mathbf{4 , 2}$ & & $\mathbf{3 , 8}$ & $\mathbf{4 , 3}$ & \\
\hline
\end{tabular}


Daniela apresentou o aumento mais significativo na definição verbal, de 2,6 no préteste para 3,6 pontos no pós-teste, um aumento de 38,5\%. Em seguida, Vítor obteve um aumento de $21,2 \%$, na média, com 3,3 no pré e 4 no pós-teste. A média de Rogério demonstrou diferença de $7,5 \%$, com alteração na média de 4 para 4,3 pontos.

As médias da definição verbal do conceito "trem" permaneceram estáveis nos casos de Bruno e Fábio com o valor de 4,6 pontos em ambas. Na avaliação dos desenhos de "trem", o aumento mais expressivo foi de Rogério, que passou de 3,3 para 4,6, totalizando 39,4\%\% de aumento na média. Bruno e Fábio apresentam o mesmo aumento, de 3,6 no pré para 4 no pósteste, uma diferença de $11,1 \%$ de uma etapa para outra. A média de Vítor aumentou em 7\%, de 4,3 para 4,6 pontos. A média de Daniela, na avaliação dos desenhos do conceito "trem", não sofreu alteração, mantendo 4,3 pontos na avaliação do desenho de "trem.

Tabela 6 - Conceito "Leão": avaliação da definição e o desenho pelos juízes.

\begin{tabular}{lcccccc}
\hline & \multicolumn{3}{c}{ Definição verbal } & \multicolumn{3}{c}{ Desenho } \\
Sujeito & Pré & Pós & Diferença em \% & Pré & Pós & Diferença em \% \\
& 4,3 & 4,3 & 0 & 3,3 & 3,6 & 9,1 \\
& 4,6 & 4,3 & $-6,5$ & 2,6 & 2,3 & $-11,5$ \\
Vítor & 1 & 1,3 & 30 & 1,3 & 1,3 & 0 \\
Bruno & 3 & 3,3 & 10 & 4 & 3,6 & -10 \\
Raniela & 3,3 & 4,6 & 39,4 & 1,3 & 4 & 207,7 \\
Fábio & $\mathbf{3 , 2}$ & $\mathbf{3 , 5}$ & $\mathbf{1 4 , 6}$ & $\mathbf{2 , 5}$ & $\mathbf{2 , 9}$ & $\mathbf{3 9}$ \\
\hline Média geral & & & &
\end{tabular}

O sujeito com maior aumento nas médias da definição verbal do conceito "leão" foi Fábio, que obteve média 3,3 no pré-teste e evoluiu para 4,6 no pós-teste, um aumento de $39,4 \%$. Daniela apresentou uma diferença de $30 \%$, a média aumentou de 1 para 1,3 pontos. O aumento também pode ser observado em Rogério, que obteve 3 pontos no pré e 3,3 no pósteste, $10 \%$ de melhora da definição verbal. A média de 4,3 de Vítor não mudou de uma etapa para outra. Por outro lado, a média de Bruno apresentou percentual negativo de $-6,5 \%$ na comparação entre pré e pós-teste, com médias de 4,6 e 4,3 pontos.

Nos desenhos, o aumento mais expressivo foi o de Fábio, que obteve 1, 3 no pré-teste e passou para 4 pontos no pós-teste, um aumento equivalente a $207,7 \%$ na avaliação do desenho de "leão". Vítor também obteve aumento na média dos desenhos, de 3,3 para 3,6 pontos, a diferença ficou em $9,1 \%$. 
A média de Daniela permaneceu estável, 1,3 pontos, na avaliação dos desenhos do conceito "leão" em ambas as etapas da pesquisa. Bruno e Rogério apresentaram uma diminuição semelhante nas médias. A média de Rogério caiu de 4 para 3,6, uma diferença de $-11,5 \%$, e a de Bruno apresentou diferença negativa de $-10 \%$, de 2,6 para 3,3 pontos.

Tabela 7 - Conceito "Prédio": avaliação da definição e o desenho pelos juízes.

\begin{tabular}{|c|c|c|c|c|c|c|}
\hline \multicolumn{7}{|c|}{ Prédio } \\
\hline \multirow{2}{*}{ Sujeito } & \multicolumn{3}{|c|}{ Definição verbal } & \multicolumn{3}{|c|}{ Desenho } \\
\hline & Pré & Pós & Diferença em \% & Pré & Pós & Diferença em \% \\
\hline Vítor & 4,6 & 4,6 & 0 & 4,3 & 4,6 & 7 \\
\hline Bruno & 4,6 & 4,6 & 0 & 4 & 2,3 & $-42,5$ \\
\hline Daniela & 2,3 & 3,3 & 43,5 & 4 & 5 & 25 \\
\hline Rogério & 4 & 3,3 & $-17,5$ & 4,3 & 3,6 & $-16,3$ \\
\hline Fábio & 4,6 & 2,6 & $-43,5$ & 4,6 & 4,6 & 0 \\
\hline Média geral & 4 & 3,6 & & 4,2 & 4 & \\
\hline
\end{tabular}

Em relação ao conceito "prédio", apenas Daniela apresentou aumento na média da definição verbal do conceito "prédio", com média inicial de 2,3 e final de 3,3, o que representa um aumento em 43,5\%. Para Vítor e Bruno média obtida se manteve em 4,6.

A redução mais significativa na média de definição verbal de "prédio" ocorreu com Fábio, que obteve média de 4,6 no pré-teste e caiu para 2,6 no pós-teste, ou seja, uma diferença de $-43,5 \%$. Rogério também apresentou uma diferença negativa entre as médias nas duas etapas de avaliação, de 17,5\%, com queda de 4 para 3,3 pontos,

Na avaliação dos desenhos, a Tabela 7 demonstra que o aumento mais expressivo nas médias do conceito "prédio" ocorreu com Daniela, que mudou de 4 para 5 pontos no pósteste, o equivalente a $25 \%$ de aumento. Vítor também apresentou aumento, porém menor, de $7 \%, \operatorname{com} 4,3$ pontos no pré e 4,6 no pós-teste.

A diminuição mais relevante da média obtida na avaliação dos desenhos ocorreu com Bruno, que recebeu 4 no pré-teste e acabou com 2,3 no pós-teste, uma diferença equivalente a $-42 \%$ na média. É seguido por Rogério, cuja média diminuiu 4,3 para 3,6, o que representa uma redução de $-16,3 \%$.

As médias de Fábio não tiveram mudança na avaliação dos desenhos entre pré e pósteste, que permaneceu 4,6 em ambas as etapas. 
Tabela 8 - Conceito “Ilha”: avaliação da definição e o desenho pelos juízes.

\begin{tabular}{lcccccc}
\hline & \multicolumn{4}{c}{ Definição verbal } & \multicolumn{3}{c}{ Desenho } \\
Sujeito & Pré & Pós & Diferença em \% & Pré & Pós & Diferença em \% \\
\hline Vítor & 3,6 & 4,6 & 27,8 & 3 & 4 & 33,3 \\
Bruno & 2,6 & 2,6 & 0 & 1,3 & 1,6 & 23,1 \\
Daniela & 1 & 1 & 0 & 2,3 & 1,3 & $-43,5$ \\
Rogério & 1,3 & 4,3 & 230,8 & 3 & 3,3 & 10 \\
Fábio & 4,6 & 4,6 & 0 & 5 & 5 & 0 \\
\hline \multicolumn{1}{c}{ Média geral } & $\mathbf{2 , 6}$ & $\mathbf{3 , 4}$ & & $\mathbf{2 , 9}$ & $\mathbf{3}$ & \\
\hline
\end{tabular}

A Tabela 8 mostra que, em relação ao conceito "ilha" o sujeito com aumento mais expressivo na média relacionada à definição verbal foi Rogério, que obteve 1,3 no pré-teste e 4,3 no pós-teste; na comparação entre estas duas etapas a mudança foi de $230,8 \%$. O segundo melhor desempenho foi o de Vítor, que apresentou um aumento de $27,8 \%$, com 3,6 pontos no pré e 4,6 no pós-teste.

Os demais sujeitos não apresentaram mudanças entre as duas etapas de avaliação da definição verbal do conceito "ilha". Fábio permaneceu com 4,6, Bruno com 2,6 e Daniela com 1 ponto.

Com relação aos desenhos do conceito "ilha", a média de Vítor apresentou diferença positiva de 33,3\%, com 3 pontos no pré para 4 no pós-teste. A média de Bruno passou de 1,3 para 1,6, uma melhora no desempenho de $23,1 \%$. O aumento na média de Rogério foi de $10 \%$, de 3 pontos no pré-teste para 3,3 no pós. A média de Fábio se manteve em 5 pontos na avaliação dos desenhos que representaram o conceito "ilha". Por outro lado, Daniela apresentou uma mudança de $-43,5 \%$, com a queda da média de 2,3 no pré-teste para 1,3 pontos no pós teste.

A Figura 2 apresenta um gráfico de barras paralelas para visualização geral do desempenho dos sujeitos em relação aos conceitos pesquisados. Os dados para a construção do gráfico foram as médias gerais da avaliação das definições verbais. 


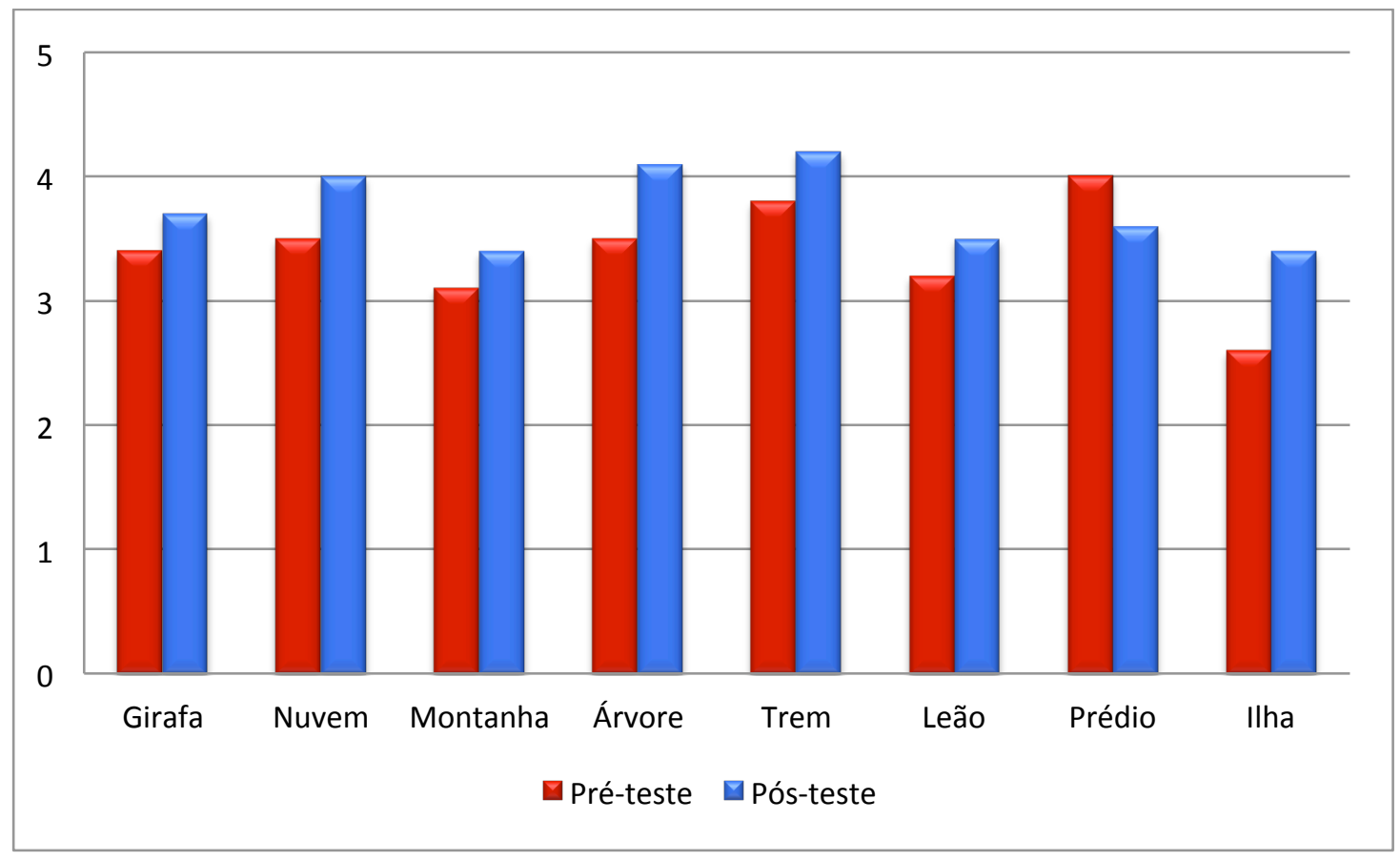

Figura 2 - Comparativo entre as médias gerais das definições verbais dos conceitos.

De maneira geral, nota-se que em todos os conceitos a média aumentou, exceção feita a "prédio", no qual as notas foram maiores no pré-teste. Outro ponto importante é que as médias de pré-teste encontram-se próximas e acima dos 3 pontos, o que indica que os sujeitos que participaram da pesquisa já tinham boas definições verbais dos conceitos, mas não boas o suficiente para que não houvesse espaço para o aprimoramento de suas representações. Apenas a média de "ilha" encontra-se abaixo dos 3 pontos no pré-teste, mas no pós-teste a média se elevou, ultrapassando a linha dos três pontos. Nos outros conceitos as médias do pós teste encontram-se entre 3 e 4 pontos.

Por fim, não houve uma mudança maior do que um ponto entre as definições verbais do pré para o pós-teste, o que pode indicar limitações quanto ao uso do instrumento ou ao curto período de tempo e ao número de sessões de treinamento que os sujeitos tiveram para aprendizagem.

A Figura 3 mostra um gráfico de barras paralelas verticais, no qual é comparado o desempenho dos sujeitos nos desenhos nas etapas de pré e pós teste. Assim como no gráfico anterior, o objetivo é visualizar, de maneira geral, o desempenho dos sujeitos pesquisados em cada conceito. 


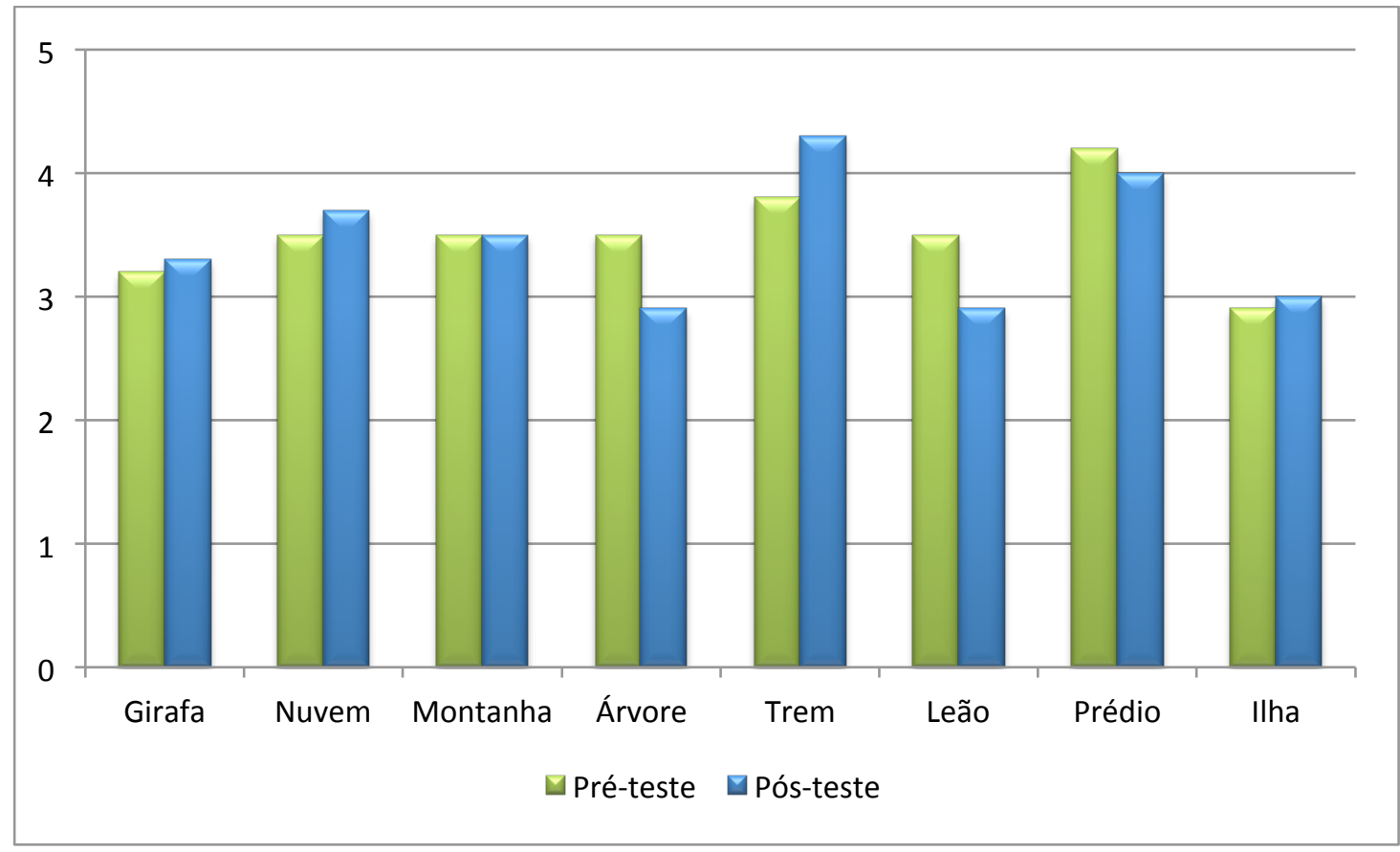

Figura 3 - Comparativo entre as médias gerais dos desenhos dos conceitos.

Nota-se que há um equilíbrio entre o aumento e a diminuição da média no pós-teste. Nos conceitos "girafa", "nuvem", "trem" e "ilha" houve aumento, mesmo que pequeno. Por outro lado, em "árvore", "leão" e "prédio" a média caiu em relação ao pré-teste, principalmente nos dois primeiros. Em "montanha" não houve mudança entre as duas etapas comparadas no gráfico.

As médias do pré-teste encontram-se entre os 3 e 4 pontos, com "prédio" um pouco acima e "ilha" um pouco abaixo. Isto demonstra que os sujeitos conseguiram representar bem os conceitos graficamente. Já no pós-teste as médias oscilaram entre os 3 e 4 pontos, com "árvore" e "leão" um pouco abaixo dos 3 pontos e "trem" um pouco acima do 4 pontos.

O fato das médias ocuparem uma faixa próxima de pontuação indica que as mudanças na qualidade dos desenhos não foi altamente discrepante em nenhum dos conceitos. Neste sentido, pode-se observar que, em cada conceito, o resultado do pós-teste foi próximo ao do pré-teste. 


\subsection{Análise dos resultados por sujeitos}

A seguir serão apresentados os dados de desempenho nas avaliações por sujeito, para que se possa avaliar as mudanças individuais nas representações dos conceitos pesquisados neste trabalho.

Tabela 9 - Avaliação do desempenho do sujeito de pesquisa Vítor.

\begin{tabular}{lcccccc}
\hline & \multicolumn{3}{c}{ Definição verbal } & \multicolumn{3}{c}{ Desenho } \\
Conceitos & Pré & Pós & Diferença em \% & Pré & Pós & Diferença em \% \\
\hline Girafa & 5 & 4,5 & -10 & 4,6 & 5 & 8,7 \\
Nuvem & 4 & 4,6 & 15 & 4,3 & 4,3 & 0 \\
Montanha & 4,3 & 4,6 & 7 & 5 & 5 & 0 \\
Árvore & 4,6 & 4,3 & $-6,5$ & 5 & 4 & -20 \\
Trem & 3,3 & 4 & 21,2 & 4,3 & 4,6 & 7 \\
Leão & 4,3 & 4,3 & 0 & 3,3 & 3,6 & 9,1 \\
Prédio & 4,6 & 4,6 & 0 & 4,3 & 4,6 & 7 \\
Ilha & 3,6 & 4,6 & 27,8 & 3 & 4 & 33,3 \\
\hline Média geral & $\mathbf{4 , 2}$ & $\mathbf{4 , 4}$ & $\mathbf{6 , 8}$ & $\mathbf{4 , 2}$ & $\mathbf{4 , 3}$ & $\mathbf{5 , 6}$ \\
\hline
\end{tabular}

A tabela acima mostra que, de maneira geral, Vítor se manteve estável na representação dos conceitos, tanto nas definições verbais quanto nos desenhos. A média geral das definições verbais aumentou 0,2 pontos, de 4,2 para 4,4. A média geral das diferenças percentuais entre pré e pós-teste foi de $6,8 \%$. Já na avaliação dos conceitos pelos desenhos o aumento foi de 0,1 , de 4,2 no pré para 4,3 no pós-teste, enquanto a média geral das diferenças entre as duas etapas avaliadas foi de 5,6\%.

De acordo com os dados obtidos nas avaliações sobre o material de Vítor, os conceitos que apresentaram aumento nas médias das definições verbais foram "ilha", "trem", "nuvem" e "montanha".

Em "ilha", a diferença entre pré e pós-teste foi de $27 \%$, com 3,6 pontos no pré-teste e 4,6 no pós. O aumento na média de "trem" foi de $21,2 \%$, com média inicial de 3,3 e 4 no pósteste. Obteve um aumento de 15\%, com média inicial de 4 pontos e final de 4,6 em "nuvem". Houve um aumento na média de "montanha", de 4,3 para 4,6 pontos, a diferença equivale a 7\%. Já nos conceitos "leão" e "prédio", as médias continuaram as mesmas, 4,3 e 4,6 respectivamente. No conceito "árvore", Vítor apresentou uma diminuição de 4,6 no pré e 4,3 
pontos no pós-teste, uma diferença negativa de $-6,5 \%$. Uma redução maior ocorreu em "girafa", $-10 \%$, de 5 para 4,5.

Em relação à avaliação dos desenhos, o conceito "ilha" foi o que apresenta maior evolução, de acordo com a Tabela 9. No pré-teste a média foi 3 e no pós 4 pontos, o que representa um aumento de 33,3\%. Em segundo lugar está "leão", com uma diferença positiva de 9,1, com aumento na média de 3,3 para 3,6 pontos. No conceito "girafa" o aumento da média corresponde a $8,7 \%$, de 4,6 para 5. Os conceitos "trem" e "prédio" tiveram aumento de $7 \%$ nas médias, mudaram de 4,3 para 4,6 em ambos os casos.

Apenas nos desenhos referentes ao conceito "árvore" a média de Vítor diminuiu. A média caiu de 5 pontos no pré para 4 no pós-teste, o que corresponde a uma diferença percentual de $-20 \%$.

$\mathrm{Na}$ avaliação dos desenhos de "nuvem" e "montanha" as médias permaneceram as mesmas, com 4,3 para "nuvem" e "5" para "montanha".

Tabela 10 - Avaliação do desempenho do sujeito de pesquisa Bruno.

\begin{tabular}{lcccccc}
\hline & \multicolumn{3}{c}{ Definição verbal } & \multicolumn{3}{c}{ Desenho } \\
Conceitos & Pré & Pós & Diferença em \% & Pré & Pós & Diferença em \% \\
\hline Girafa & 4 & 3 & -25 & 2 & 2,3 & 15 \\
Nuvem & 4,3 & 3,6 & $-16,3$ & 4 & 3,6 & -10 \\
Montanha & 2,6 & 3,3 & 26,9 & 1,3 & 2 & 53,8 \\
Árvore & 4 & 4,6 & 15 & 4,3 & 2 & $-53,5$ \\
Trem & 4,6 & 4,6 & 0 & 3,6 & 4 & 11,1 \\
Leão & 4,6 & 4,3 & $-6,5$ & 2,6 & 2,3 & $-11,5$ \\
Prédio & 4,6 & 4,6 & 0 & 4 & 2,3 & $-42,5$ \\
Ilha & 2,6 & 2,6 & 0 & 1,3 & 1,6 & 23,1 \\
\hline Média geral & $\mathbf{3 , 9}$ & $\mathbf{3 , 8}$ & $\mathbf{- 0 , 7}$ & $\mathbf{2 , 8}$ & $\mathbf{2 , 5}$ & $\mathbf{- 1 , 8}$ \\
\hline
\end{tabular}

A Tabela 10 demonstra que, de maneira geral, as representações dos conceitos por Bruno se mantiveram estáveis. Nas definições verbais, a média geral de desempenho caiu apenas 0,1 pontos, de 3,9 para 3,8 e nos desenhos a média geral diminuiu 0,3 pontos, de 2,8 no pré-teste para 2,5 no pós-teste. Em relação às médias das diferenças percentuais, houve uma queda de $-0,7 \%$ no desempenho dos sujeitos na definição verbal e $-1,8 \%$ nos desenhos.

O conceito "montanha" foi o que apresentou maior crescimento da média nas definições verbais de Bruno, com 2,6 no pré-teste e 3,3 no pós-teste, um aumento de 26,9\% 
da média. Em seguida, aparece "árvore", que teve um aumento de 15\%, passando de 4 para 4,6 pontos. Os conceitos "trem", "prédio" e "ilha" não tiveram suas médias alteradas de uma etapa para outra, com 4,6 pontos para os dois primeiros e 2,6 para o último.

Já a média da definição verbal do conceito "girafa" diminuiu 1 ponto, de 4 no pré para 3 no pós-teste, uma diferença equivalente a $-25 \%$. Outra diminuição pode ser observada em “nuvem", no qual o sujeito obteve 4,3 no pré-teste e 3,6 no pós, uma redução em -16,3\%. Na definição verbal de leão, a diferença entre as médias de pré e pós-teste foi $-6,5 \%$, com uma diminuição de 4,6 para 4,3 pontos.

Nos desenhos de Bruno o conceito "montanha" aparece com a maior diferença positiva, $53,8 \%$, com 1,3 no pré-teste e 2 no pós-teste. Em seguida aparecem "ilha", que teve média inicial 1,3 e final 1,6 pontos, com $23,1 \%$ de aumento; "girafa", que passou de 2 para 2,3, o equivalente a $23,1 \%$ e "trem", que mudou de 3,6 para 4 pontos, uma diferença de $11,1 \%$; "girafa", que passou de 2 para 2,3, o equivalente a $23,1 \%$.

Os demais conceitos avaliados por desenhos apresentaram diminuição na média. Aquele com maior diminuição foi "árvore", que caiu de 4,3 para 2 pontos, uma redução equivalente a $-53,8 \%$. Bruno também apresentou queda na média de "prédio", que mudou de 4 pontos no pré para 2,3 no pós-teste, uma diferença de $-42,5 \%$. Os conceitos "nuvem" e "leão" tiveram uma diminuição menos significativa. Em "leão" a média caiu de 2,6 para 2,3, o equivalente a $-11, \%$ e em "nuvem” diferença entre pré e pós-teste foi de $-10 \%$, com queda de 4 para 3,6 pontos.

Tabela 11 - Avaliação do desempenho do sujeito de pesquisa Daniela.

\begin{tabular}{lcccccc}
\hline & \multicolumn{4}{c}{ Daniela } & \multicolumn{3}{c}{ Desenho } \\
Conceitos & Pré & Pós & Diferença em \% & Pré & Pós & Diferença em \% \\
\hline Girafa & 1,6 & 3,3 & 106,2 & 3,6 & 3 & $-16,7$ \\
Nuvem & 2 & 3,3 & 65 & 3 & 4,6 & 53,3 \\
Montanha & 1 & 1,3 & 30 & 3,6 & 3,3 & $-8,3$ \\
Árvore & 1,6 & 3 & 87,5 & 3,6 & 3 & $-16,7$ \\
Trem & 2,6 & 3,6 & 38,5 & 4,3 & 4,3 & 0 \\
Leão & 1 & 1,3 & 30 & 1,3 & 1,3 & 0 \\
Prédio & 2,6 & 3,3 & 26,9 & 4 & 5 & 25 \\
Ilha & 1 & 1 & 0 & 2,3 & 1,3 & $-43,5$ \\
\hline Média geral & $\mathbf{1 , 6}$ & $\mathbf{2 , 5}$ & $\mathbf{4 8}$ & $\mathbf{3 , 2}$ & $\mathbf{3 , 2}$ & $\mathbf{4 , 6}$ \\
\hline
\end{tabular}


Na tabela acima verifica-se que houve um aumento significativo na média geral das definições verbais dos conceitos de Daniela, com 1,6 no pré e 2,5 no pós-teste. A média geral das diferenças entre pré e pós-teste foi $48 \%$ positiva. Os desenhos, entretanto, mantiveram a mesma média geral, de 3,2 pontos, enquanto a média das diferenças entre as duas etapas foi de $4,6 \%$.

A alteração mais significativa nas definições verbais se deu no conceito "girafa", em que Daniela obteve média 1,6 no pré-teste e 3 pontos no pós, um aumento de 106,2\%. Em segundo lugar aparece "árvore", com 1,6 no pré-teste e 3 no pós, o que representa 87,5\% de aumento da média. Em "nuvem" a média de Daniela passou de 2 para 3,3 pontos, o equivalente a $65 \%$ de aumento e em "trem" a média cresceu 1 ponto, de 2,6 para 3,6, o que representa um aumento de 38,5\%. Nos conceitos "montanha" e "leão", as médias praticamente se mantiveram estáveis com a mudança de 1 para 1,3 pontos em ambos os casos, uma diferença de $30 \%$ entre pré e pós-teste. A média do conceito "prédio" apresentou aumento de $36,9 \%$, com a mudança de 2,6 pontos no pré-teste para 3,3 no pós-teste. Por fim, a definição verbal de "ilha” permaneceu estável, com 1 ponto nas duas etapas de avaliação.

Em relação aos desenhos de Daniela, representada na Tabela 11, "nuvem" teve o aumento mais significativo, 53,3\%, com 3 pontos no pré e 4,6 no pós-teste. Em "prédio" houve um aumento de $25 \%$, com média 4 no pré e 5 no pós-teste. Nos conceitos "trem" e "leão" as médias se mantiveram inalteradas, com 4,3 e 1,3, respectivamente. Na avaliação de "ilha" houve uma redução na média, com 2,3 no pontos no pré-teste e 1,3 no pós-teste, uma diferença de $-43,5 \%$. Os desenhos de "girafa" e "árvore" também apresentaram redução da média. Em ambos os casos a média passou de 3,6 para 3 pontos, o equivalente a $-16,7 \%$ em ambos os casos. Em “montanha” Daniela obteve 3,6 no pré-teste e 3,3 no pós, que representa a diferença de $-8,3 \%$. 
Tabela 12 - Avaliação do desempenho do sujeito de pesquisa Rogério.

\begin{tabular}{lcccccc}
\hline & \multicolumn{3}{c}{ Rogério } & \multicolumn{3}{c}{ Desenho } \\
Conceitos & Pré & Pós & Diferença em \% & Pré & Pós & Diferença em \% \\
\hline Girafa & 3,3 & 3,3 & 0 & 3,6 & 3,3 & $-8,3$ \\
Nuvem & 3,3 & 4 & 21,2 & 2,3 & 4 & 73,9 \\
Montanha & 3 & 4 & 33,3 & 3 & 4 & 33,3 \\
Árvore & 3,3 & 4 & 21,2 & 4,6 & 3,3 & $-28,3$ \\
Trem & 4 & 4,3 & 7,5 & 3,3 & 4,6 & 39,4 \\
Leão & 3 & 3,3 & 10 & 4 & 3,6 & -10 \\
Prédio & 4 & 3,3 & $-17,5$ & 4,3 & 3,6 & $-16,3$ \\
Ilha & 1,3 & 4,3 & 230,8 & 3 & 3,3 & 10 \\
\hline Média geral & $\mathbf{3 , 1}$ & $\mathbf{3 , 8}$ & $\mathbf{3 8 , 3}$ & $\mathbf{3 , 5}$ & $\mathbf{3 , 7}$ & $\mathbf{1 1 , 7}$ \\
\hline
\end{tabular}

A tabela acima mostra a média geral das avaliações das definições verbais de Rogério aumentou de 3,1 para 3,8. As diferenças entre as médias de pré e pós-teste apresentaram média geral de 38,3\% nas definições verbais. Nos desenhos a média geral se manteve estável, aumentou de 3,5 no pré e 3,7 no pós-teste. A média geral das diferenças entre as duas etapas apresentou aumento de $11 \%$.

Nas médias das definições verbais, pode-se notar o aumento significativo referente ao conceito "ilha", em que a média passou de 1,3 para 4,3, um aumento de 230,8\%. Seguidamente, aparece "montanha" com 3 pontos no pré-teste e 4 no pós-teste, diferença que aponta uma melhora de 33,3\%. Em "nuvem" e "árvore" o aumento foi de 21,2\%. Nos dois conceitos, a média da definição verbal de Rogério aumentou de 3,3 para 4 pontos. Em relação ao conceito "leão", houve aumento de $10 \%$, com 3 pontos no pré e 3,3 no pós-teste. Nos desenhos de "trem" Rogério obteve 4 no pré-teste e 4,3 no pós, uma diferença de 7,5\%. No conceito "girafa" a média foi inalterada, continuou em 3,3. Na média da definição verbal de “prédio" houve uma queda de 4 pontos para 3,3, uma diferença de $-17,5 \%$.

Em relação às médias dos desenhos de Rogério, o conceito que apresentou a mudança mais significativa foi "nuvem", que passou de 2,3 para 4, o que representa um aumento de 73,9\%. Em segundo lugar está "trem”, com 39,4\%, pois mudou de 3,3 para 4,6 pontos. Em seguida aparece "montanha" com 3 no pré e 4 no pós-teste, diferença de 33,3\% na avaliação deste conceito. Na avaliação dos desenhos de "ilha" houve um aumento de 3 no pré-teste para 3,3 no pós, o que equivale a $10 \%$. 
Por outro lado, Rogério apresentou diminuição na média do conceito "árvore", que passou de 4,6 para 3,3 pontos, uma diferença negativa de -28,3\%. Em "prédio" a variação entre as médias foi de $-16,3 \%$, com 4,3 pontos no pré e 3,6 no pós-teste. No conceito "leão" a redução equivale a $-10 \%$, com 4 no pré e 3,6 pontos no pós-teste. Já em "girafa" a média foi reduzida de 3,6 para 3,3 pontos, o que representa um diferença de $-8,3 \%$.

Tabela 13 - Avaliação do desempenho do sujeito de pesquisa Fábio.

\begin{tabular}{lcccccc}
\hline & \multicolumn{3}{c}{ Fefinição verbal } & \multicolumn{3}{c}{ Desenho } \\
Conceitos & Pré & Pós & Diferença em \% & Pré & Pós & Diferença em \% \\
\hline Girafa & 3,3 & 4,3 & 30,3 & 2,3 & 3,3 & 43,5 \\
Nuvem & 4,3 & 4,6 & 7 & 4,3 & 2,3 & $-46,5$ \\
Montanha & 5 & 4 & -20 & 5 & 3,3 & -34 \\
Árvore & 4,3 & 5 & 16,3 & 3,3 & 2,3 & $-30,3$ \\
Trem & 4,6 & 4,6 & 0 & 3,6 & 4 & 11,1 \\
Leão & 3,3 & 4,6 & 39,4 & 1,3 & 4 & 207,7 \\
Prédio & 3,6 & 4 & 11,1 & 4,6 & 2,6 & $-43,5$ \\
Ilha & 4,6 & 4,6 & 0 & 5 & 5 & 0 \\
\hline Média geral & $\mathbf{4 , 1}$ & $\mathbf{4 , 4}$ & $\mathbf{1 0 , 5}$ & $\mathbf{3 , 6}$ & $\mathbf{3 , 3}$ & $\mathbf{1 3 , 5}$ \\
\hline
\end{tabular}

A Tabela 13 mostra que a média geral das definições verbais aumentou de 4,1 para 4,4, enquanto a média geral das diferenças entre as médias de pré e pós-teste foi de 10,5\%. Por outro lado, houve diminuição das médias gerais nos desenhos, de 3,6 para 3,3 pontos. No entanto, a média geral das comparações entre pré e pós-teste apresentou um desempenho positivo em $13,5 \%$.

Em relação às definições verbais de Fábio, o conceito com aumento mais significativo na média foi "leão", com 3,3 no pré-teste e 4,6 no pós, um aumento equivalente a 39,4\%. Em "girafa" a média do pré-teste foi de 3,3 pontos e atingiu os 4,3 pontos no pós-teste, o que representa um aumento de 30,3\%. A média de "árvore" mudou de 4,3 para 5, o equivalente a 16,3\%. Já a definição "prédio" teve um aumento de 11,1\%, com o aumento de 3,6 para 4 pontos. Na avaliação das definições verbais de "nuvem", a média aumentou de 4,3 no pré para 4,6 no pós-teste, uma diferença positiva de 7\%. Os conceitos "trem" e "ilha" se mantiveram estáveis, com 4,6 pontos nas duas etapas. O único conceito com diferença negativa entre as duas etapas avaliadas foi montanha, com média inicial de 5 pontos e final de 4 pontos, ou seja, $-20 \%$. 
Em relação aos desenhos avaliados de Fábio, o conceito com aumento mais significativo foi "leão" em que obteve 1,3 no pré-teste e 4 no pós, um aumento de $207,7 \%$. Em seguida, pode-se notar que em "girafa" a média aumentou de 2,3 para 3,3, o que representa 43,5\% de diferença positiva. Já o conceito "trem" teve aumento de 3,6 para 4 pontos, o equivalente a $11,1 \%$, exatamente a mesma diferença verificada na definição verbal deste conceito. A média de "ilha" permaneceu estável, com 5 pontos nas duas etapas de avaliação dos desenhos.

No entanto, a representação gráfica de "nuvem" diminuiu de 4,3 no pré-teste para 2,3 pontos no pós, o que representou uma redução de -46,5\%. A diminuição também ocorreu para o conceito "prédio", de 4,6 para 2,6 pontos, o equivalente a -43,5\%. Logo em seguida está "montanha", com redução de 5 para 3,3 pontos, o equivalente a $-34 \%$. Fábio também teve diminuição na média de "árvore", que passou de 3,3 para 2,3, uma redução em -30,3\%.

A Figura 4 apresenta um gráfico de barras verticais paralelas, no qual são comparadas as médias gerais de desempenho dos sujeitos nas definições verbais dos conceitos. Com isto, pode se ter uma ideia geral sobre as mudanças que ocorreram com cada um dos sujeitos.

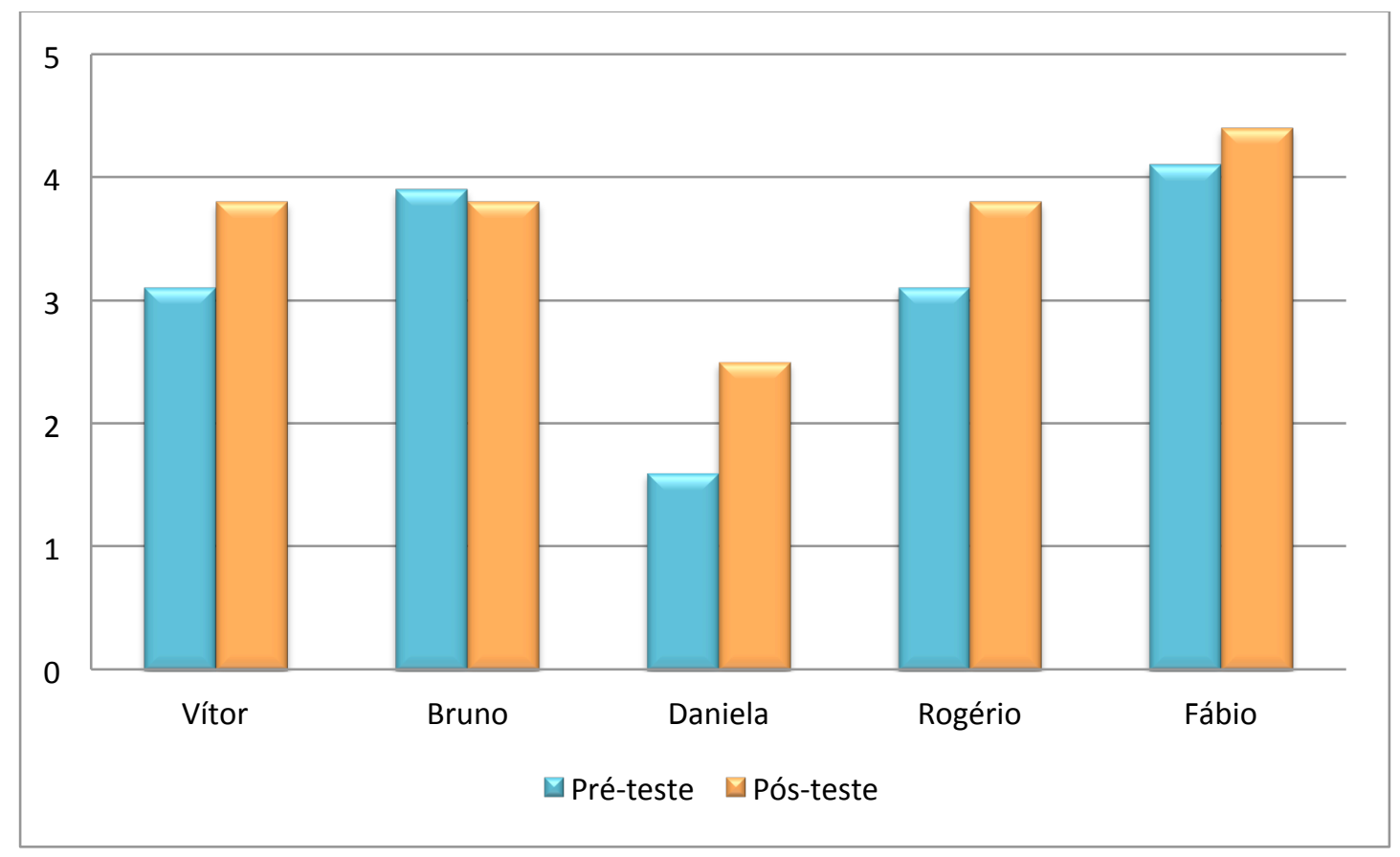

Figura 4 - Comparativo entre as médias gerais das definições verbais dos sujeitos.

Nota-se que o grupo de sujeitos era heterogêneo em relação conhecimento que possuíam em relação aos conceitos, mesmo após o período de treinamento. Daniela, por 
exemplo, apresentou média de pré-teste entre 1 e 2, enquanto Fábio já partiu da linha dos 4 pontos.

Apenas Bruno não apresentou elevação da média geral, os demais sujeitos demonstraram melhora nas definições verbais na etapa do pós-teste. Esta melhora não colocou todos os sujeitos no mesmo patamar, mas indica que, no comparativo individual, as mudanças foram significativas, levando-se em conta o curto período de treinamento.

A Figura 5 apresenta, de maneira semelhante à figura anterior, a comparação entre as médias gerais nas avaliações dos desenhos, de acordo com os sujeitos.

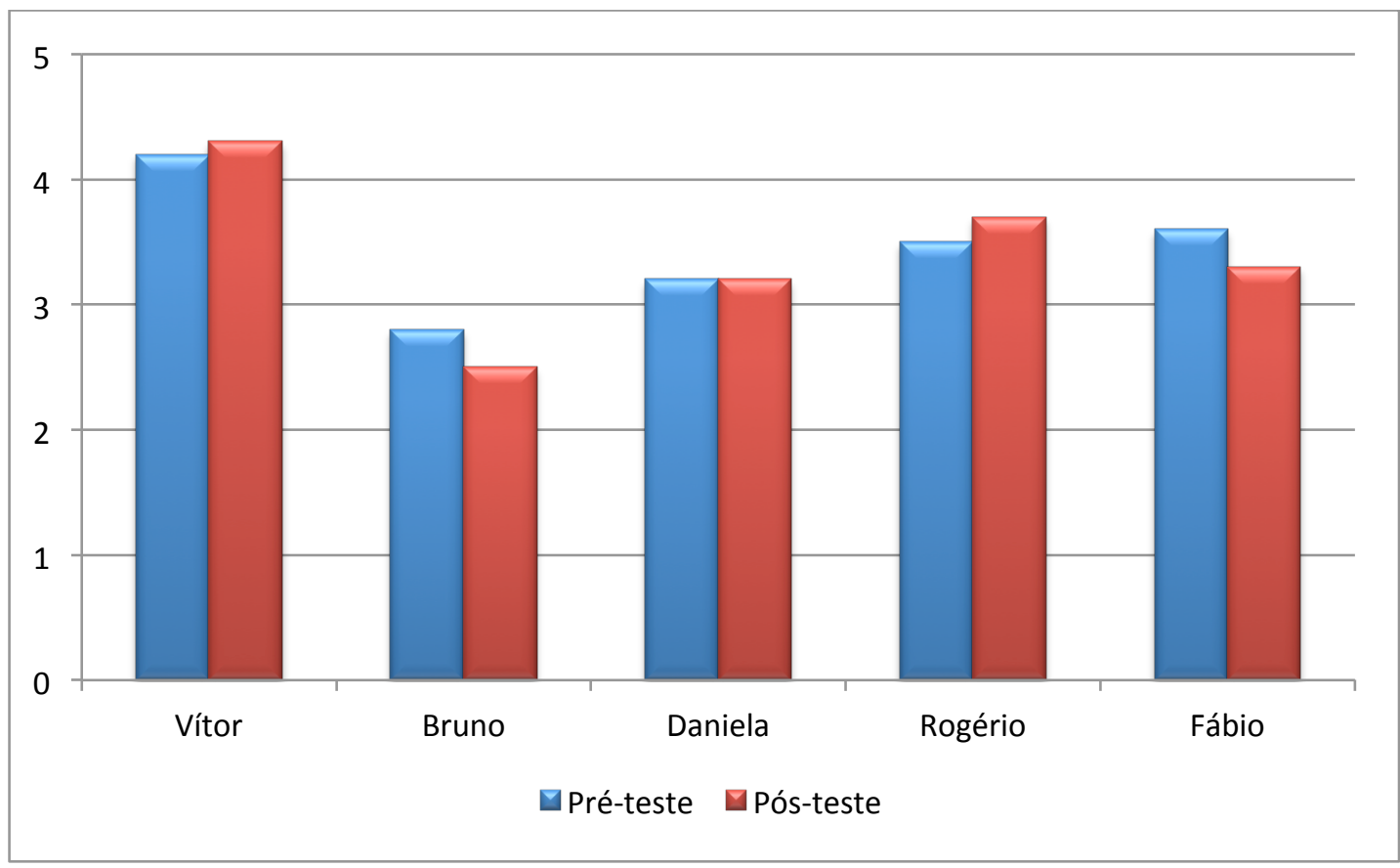

Figura 5 - Comparativo entre as médias gerais dos desenhos dos sujeitos.

De maneira geral, não houve grande mudança na qualidade dos desenhos em nenhum dos sujeitos. O desempenho do grupo, nas duas etapas avaliadas, teve uma pequena faixa de variação aproximada entre 2,5 e 3,5 pontos, com exceção de Vítor, que manteve-se acima da linha de 4 pontos. A partir destes dados pode-se considerar que aprendizagem de desenhos não foi muito significativa, uma vez que as médias de pré e pós-teste foram muito próximas em todos os casos.

Outro ponto a ser considerado é que nenhum dos sujeitos teve média baixa no préteste, portanto os desenhos já funcionavam como uma maneira de representar os conceitos. 


\subsection{Comparação entre definições verbais e desenhos}

Nesta seção serão consideradas, conjuntamente, as comparações entre as mudanças ocorridas nas médias gerais das avaliações das definições e dos desenhos, levando-se em conta as etapas de pré e pós-teste.

Mesmo assumindo que, devido ao reduzido número de participantes da pesquisa, as médias gerais podem ser distorcidas pelo desempenho mais acentuado - seja positivo ou negativo - de um dos sujeitos, o autor deste trabalho entende que, ainda assim, a comparação a partir das médias apresenta um indicativo útil a respeito das diferenças entre o desempenho dos sujeitos nas definições verbais e nos desenhos e abre possibilidades para a discussão de todo o processo.

A Figura 6 apresenta um gráfico de barras verticais paralelas, nas quais estão dispostas, de acordo com os conceitos pesquisados, as médias gerais de desempenho nas definições verbais e desenhos de pré e pós-teste.

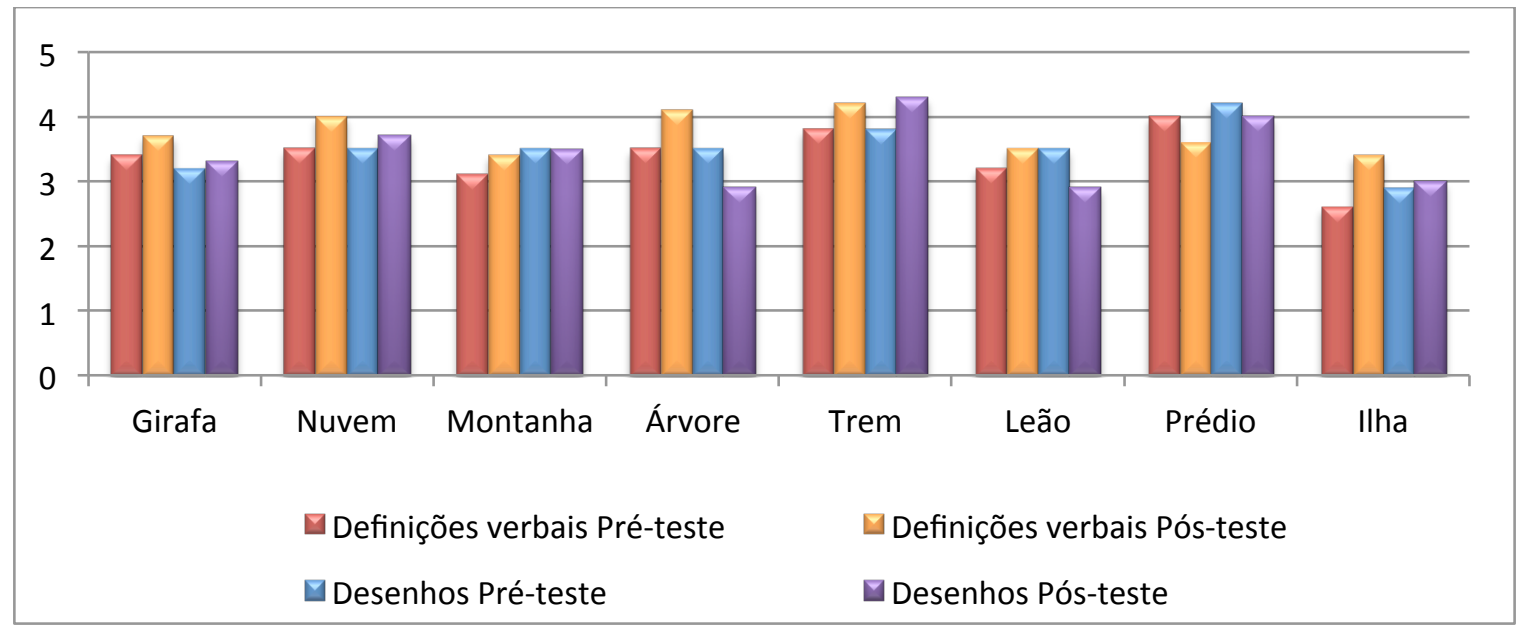

Figura 6 - Gráfico comparativo entre definições verbais e desenhos dos conceitos.

Em relação ao conceito "girafa" os sujeitos apresentaram uma melhora mais significativa na definição verbal do que no desenho. As médias dos desenhos mantiveram-se próximas à linha de 3 pontos, enquanto a média da definição verbal aproximou-se dos 4 pontos. Outro aspecto importante é que a diferença na média geral, entre pré e pós-teste, das definições verbais de "girafa", foi maior nas definições do que nos desenhos, ou seja, os sujeitos evoluíram mais nas definições verbais do que nos desenhos de "girafa". Na verdade, 
as médias gerais dos desenhos indicam que praticamente não houve mudança qualitativa na representação gráfica do conceito.

Algo semelhante ocorreu na avaliação das representações de "nuvem". Os sujeitos melhoraram suas definições verbais do conceito, mas a mesma mudança não ocorreu nos desenhos. No pré-teste as médias gerais das definições verbais e desenhos são iguais e sugerem uma boa representação do conceito, uma vez que encontram-se exatamente entre os 3 e 4 pontos. Após o período de treinamento os sujeitos enunciaram definições verbais mais precisas em relação ao pré-teste, aproximando-se dos 4 pontos na avaliação. Os desenhos também foram melhor avaliados, mas com um aumento menor comparado ao que ocorreu nas definições verbais.

No conceito "montanha" a média geral das definições verbais do pré-teste era menor do que a dos desenhos. Os sujeitos apresentaram melhoria nas definições verbais após o treinamento, mas os desenhos continuaram com a mesma média em ambas as etapas.

$\mathrm{Na}$ definição e representação gráfica do conceito "árvore" os sujeitos obtiveram a mesma média geral. Já na pós-teste, observa-se um progresso da média das definições verbais, que partiu de 3,5 e atingiu 4 pontos. Em relação aos desenhos, a média que também foi de 3,5 no pré-teste ficou abaixo dos 3 pontos. Portanto, pode-se dizer que, apesar de apresentarem melhora na definição verbal de "árvore", a representação gráfica do conceito piorou.

No conceito "trem" os sujeitos apresentaram um aumento equivalente nas médias das definições verbais e dos desenhos. A média geral do pré-teste foi a mesma, 3,8, e no pós-teste ultrapassou a linha de 4 pontos, com ligeira vantagem para os desenhos. Neste caso, a melhora das definições verbais foi acompanhada pelo progresso nos desenhos.

A definição verbal de "leão" apresentou aumento na média geral, mas nos desenhos o resultado foi inverso. De acordo com o gráfico os sujeitos souberam representar melhor este conceito por desenhos no pré-teste. No pós-teste, porém, a média geral das definições verbais atingiu o mesmo valor que a média dos desenhos no pré-teste, enquanto a média dos desenhos foi reduzida significativamente. Em resumo, os sujeitos representaram melhor o conceito por desenhos no pré-teste e melhor por definições verbais no pós-teste. 
Em relação à "prédio" nota-se que as médias foram altas, superando os 3,5 pontos. A definição verbal do pré-teste apresenta média geral equivalente às duas médias gerais observadas nos desenhos. O que chama a atenção neste caso é que a média das definições verbais diminuiu no pós-teste. Portanto, apesar de manter a mesma qualidade na representação gráfica de "prédio" os sujeitos apresentaram definições verbais menos precisas.

No pré-teste os desenhos de "ilha" foram melhor avaliados de que as definições verbais nesta mesma etapa. Após o período de treinamento os sujeitos melhoraram suas definições verbais, mas não apresentaram mudanças significativas na qualidade dos desenhos no pós-teste.

De maneira geral, após o treinamento com desenhos, os sujeitos melhoraram suas definições verbais mais do que melhoraram seus desenhos. O único conceito em que o contrário ocorreu foi "prédio", em que a média das definiçõoes verbais diminuiu e esteve abaixo das médias dos desenhos. Em "trem" e "montanha" as médias referentes às definições verbais e desenhos permaneceram estáveis e proporcionais.

A Figura 7 apresenta um gráfico de barras verticais paralelas, com as médias gerais de desempenho nas definições verbais e desenhos dos sujeitos nas etapas de pré e pós-teste.

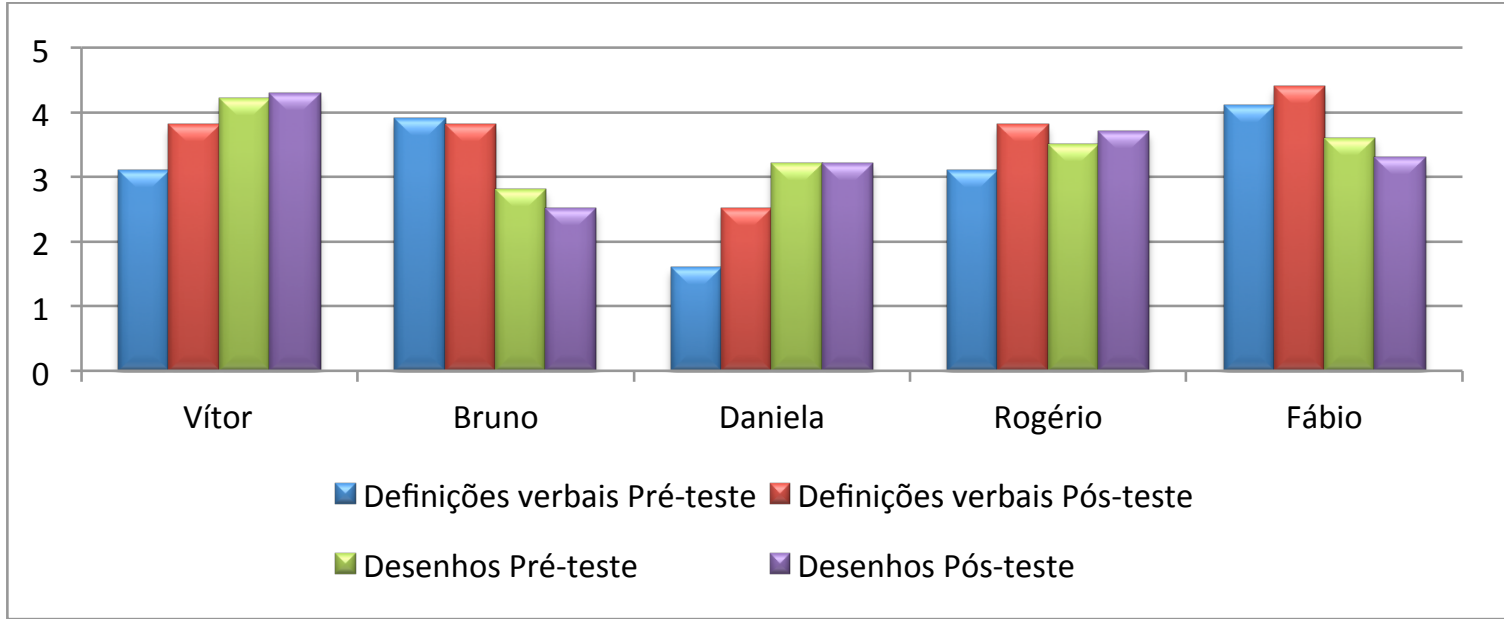

Figura 7 - Gráfico comparativo entre definições verbais e desenhos dos sujeitos.

De maneira geral, Vítor apresentou um desempenho melhor nos desenhos do que nas respostas verbais. Em relação às mudanças entre pré e pós-teste, houve progresso tanto nas médias das definições verbais quanto nos desenhos. No entanto o progresso observado entre uma etapa e outra foi maior nas definições verbais do que nos desenhos. Apesar de obter 
médias maiores nos desenhos - nas duas etapas de avaliação - o aumento da média nos desenhos foi pequeno, de apenas 0,1 pontos. Já nas definições verbais o crescimento foi de 0,7 pontos. Portanto, apesar do conseguir representar bem os conceitos graficamente, a melhora mais significativa na forma de representá-los se deu na linguagem verbal.

As médias gerais das definições verbais de Bruno foram maiores do que as médias obtidas nos desenhos em ambas as etapas da pesquisa. O sujeito foi melhor avaliado no préteste, apresentando uma pequena queda nas médias gerais das definições verbais e uma redução maior na qualidade dos desenhos. Sendo assim, pode-se dizer que este sujeito é mais competente nas representações verbais do que nos desenhos dos conceitos, e que o período de treinamento não surtiu mudanças positivas para a melhoria dos mesmos.

No caso de Daniela as médias foram mais elevadas nos desenhos. Entretanto, as médias gerais do pré e pós-teste permaneceram estáveis, um pouco acima da linha dos 3 pontos. Já nas definições verbais, as médias do pré-teste foram baixas, entre 1 e 2 . Após o período de treinamento, a média geral de desempenho nas definições verbais ficou entre 2 e 3 pontos, ou seja, pode-se considerar que houve uma melhora significativa nas representações do conceitos. Portanto, apesar de Daniela representar melhor os conceitos pesquisados de forma gráfica, a evolução mais significativa ocorreu nas definições verbais.

Rogério apresentou aumento das médias gerais no pós teste em relação às definições verbais e aos desenhos. Entretanto, a diferença observada entre as duas etapas de avaliação foi maior nas definições verbais do que nos desenhos. De acordo com as médias do pré-teste, Rogério representou, em geral, melhor os conceitos graficamente. Já no pós-teste seu desempenho nas definições verbais superou as médias dos desenhos que obteve no pré e pósteste. Entretanto, é importante observar que o aumento nas médias gerais do desenhos foi pequeno, apenar de existente, o que pode indicar maior efetividade do treinamento para as definiçõos verbais do que para os desenhos.

Em relação ao desempenho de Fábio, nota-se que as médias das definições verbais foram significativamente maiores do que as médias dos desenhos, mantendo-se acima dos 4 pontos. Na avaliação dos desenhos as médias estiveram próximas dos 3,5 pontos. No préteste, Fábio representou os conceitos de maneira mais efetiva verbalmente do que por meio de desenhos, embora as notas médias do desenho não tenham sido baixas. Já no pós-teste, ocorreu uma evolução das definições verbais, mas, ao que tudo indica, a qualidade dos 
desenhos para a representação dos conceitos diminuiu. Verificou-se, portanto, que Fábio representa melhor os conceitos verbalmente do que graficamente após o treinamento com os desenhos.

\subsection{Uma breve síntese dos resultados}

Nesta seção, serão apresentadas, à guisa de síntese, algumas tendências que puderam ser percebidas na análise dos resultados. No entender do autor desse trabalho a tendência mais significativa foi a ocorrência de mudanças mais acentuadas nas definições verbais do que nos desenhos. A melhora das definições verbais ocorreu em todos os casos, exceto com Bruno, que obteve médias praticamente estáveis neste aspecto.

Outro fator que pode ser destacado é a heterogeneidade dos sujeitos que participaram da pesquisa. Fábio e Rogério, como pode ser verificado na Figura 7, apresentaram médias altas nas definições verbais, enquanto Vítor e Bruno tiveram médias intermediárias e Daniela médias baixas. No desenhos, Vítor saiu-se muito bem, Fábio e Rogério apresentaram médias intermediárias e Daniela e Bruno tiveram as menores médias gerais. Além disso, nota-se que Fábio e Bruno representaram melhor os conceitos pela definição verbal, ao contrário de Daniela e Vítor, que demonstraram melhores representações gráficas do que verbais. Já Rogério, apresentou qualidade semelhante nas duas formas de representar os conceitos.

Em relação aos conceitos, os sujeitos não tiveram maiores dificuldades em defini-los ou desenhá-los razoavelmente, ou seja, constatou-se uma certa homogeneidade na representação dos conceitos. Dentre os oito conceitos estudados, "ilha" foi aquele no qual, em geral, os sujeitos apresentaram o pior desempenho, como pode ser visto nas Figuras 2, 3 e 6. Não que os sujeitos não conseguiram representar o conceito, mas as médias gerais (definição verbal e desenhos) não apontaram mudanças positivamente significativas, exceto nos casos de Daniela na definição verbal, Bruno nos desenhos e Vítor em ambos, como pode ser conferido na Tabela 8. Além de "ilha", os sujeitos também tiveram dificuldades em representar graficamente "árvore" e "leão"; assim como obtiveram, em geral, médias baixas na definição verbal de "montanha". Por outro lado, nos conceitos "prédio", "trem" e "nuvem", o grupo apresentou maior facilidade nas definições verbais e nos desenhos. Em "árvore”, as médias das definições verbais foram altas, em contraste com as dos desenhos. 
As hipóteses e considerações a respeito das razões que determinaram estas tendências, bem como as considerações a respeito das particularidades que não puderam ser tratadas até o momento, serão discutidas no próximo capítulo. 


\section{CAPÍTULO 6}

\section{DISCUSSÃO}

O objetivo deste trabalho consistiu em verificar de que maneira a utilização de um recurso técnico, o desenho em relevo, poderia contribuir para o processo de aquisição - ou reconstrução - de conceitos que possuem exemplares que não são de fácil apreensão aos sentidos das pessoas cegas. A partir do levantamento e escolha de conceitos desta natureza, a técnica do desenho em relevo foi utilizada para produção de exemplos táteis e, ao longo desta pesquisa, foram investigados os possíveis efeitos de transformar estímulos visuais em táteis. Após o período de treinamento com os desenhos, esperava-se que um aumento de atributos definidores nas representações dos conceitos.

Como visto no último tópico do capítulo anterior, o progresso dos sujeitos em relação aos conceitos foi mais significativo nas definições verbais do que nos desenhos. Como explicar tais resultados?

Antes disso, todavia, é importante esclarecer, dentro do possível, a noção de conceito utilizada neste trabahlo. No Capitulo 2, sessão 2.1, foram apresentadas as principais dificuldades na definição do conceito de conceito. Mesmo sem uma definição precisa e hegemônica sobre a natureza psicológica dos conceitos, há um certo consenso de que os conceitos podem ser considerados como representações mentais. Ou seja, são agrupamentos cognitivos que os sujeitos constroem no decorrer de suas vidas, em função da experiência e que reduzem a complexidade do ambiente (Lomônaco, Paula, Mello \& Almeida, 2001).

Neste aspecto a pessoa cega pode encontrar restrições na sua experiência para a formação de representações mentais em que os estímulos visuais sejam críticos. Ainda que a falta da visão não impeça, necessariamente, o desenvolvimento de conceitos precisos e adequados, deve-se considerar que em muitas situações a visão é importante para integrar as informações que são capturadas pelos outros sentidos (Amiralian, 1997).

Os conceitos que foram selecionados para a presente pesquisa são "concretos", na medida em que seus atributos são elementos físicos, ainda que não completamente tateáveis. $\mathrm{Na}$ verdade, as possibilidades de tatear os exemplos são bastante reduzidas. Mesmo que o cego possa tatear as paredes de um apartamento ou, então, calcular a altura das paredes e a 
distância do andar no qual se encontra em relação ao térreo, a integração de todas essas informações em um único conceito pode ser bastante complexa. Ou seja, embora um exemplo de prédio possua muitos atributos físicos tateáveis, não é possível apreender o todo, como pode ser feito com um objeto menor, como um telefone ou uma televisão. Neste sentido, a principal fonte de informações é a linguagem oral utilizada nos relatos de pessoas videntes ou nos meios de comunicação sonoros.

Exemplos claros da importância da comunicação oral ocorreram durante a aplicação da pesquisa. Vítor, ao ser indagado, no pré-teste, sobre a origem dos seus conhecimentos sobre "girafa", afirmou Eu vi na tv (sic). Neste caso a palavra ver pode ter sido empregada como um sinônimo de conhecer, ou apreender, como é comum em nossa língua. Para verificar se havia outra fonte de informações sobre o conceito, o pesquisador perguntou se ele havia estado em um zoológico e se tinham girafas lá. O sujeito respondeu afirmativamente, mas teve dúvidas se realmente visitou uma girafa, uma vez que só podia saber os animais que existiam no local pelo relato de terceiros. Isto fica bastante claro quando diz: Eu não toquei na girafa, mas era uma girafa, eles disseram. Vale ressaltar que Vítor possuía um conceito preciso de girafa, o que reforça a teoria de que a linguagem é uma fonte poderosa de informações para a formação de conceitos concretos.

Como verificou Nunes (2004), os atributos físicos tateáveis não são os únicos utilizados pelos cegos na definição de conceitos. De acordo com seus dados, eles também utilizam os atributos funcionais dos objetos, abstraídos de suas experiências diretas ou, então, de informações obtidas pela linguagem. No conceito "nuvem", por exemplo, os sujeitos utilizaram não apenas atributos físicos, como a comparação com o algodão, mas também buscaram explicar o ciclo da chuva. Algo semelhante ocorreu com "trem", pela sua função de transporte.

Neste sentido, a utilização de desenhos em relevo pode ser um recurso importante, para tornar certos atributos criteriais dos conceitos mais acessíveis ao tato, oferecendo ao aluno cego uma fonte preciosa de informações.

No caso do grupo que participou deste trabalho, a utilização de desenhos em relevo não substituiu a necessidade ou a importância da comunicação oral para a exploração dos atributos dos conceitos. Durante as sessões de treinamento, o pesquisador chamou a atenção para os detalhes dos desenhos que correspondiam aos atributos definidores dos conceitos. 
Durante as conversas com os sujeitos os atributos característicos também foram evocados, dependendo da necessidade que havia em tornar os exemplos compreensíveis.

Para que estas situações fiquem mais claras, é importante discorrer sobre algumas impressões abstraídas durante o contato entre o pesquisador e os sujeitos.

Como foi citado anteriormente, trata-se de um grupo heterogêneo. Como é de se esperar, cada sujeito possui uma história de vida única, que lhe confere características particulares na maneira como conhece do mundo. Por isso, serão considerados alguns aspectos particulares de cada sujeito que podem sugerir uma explicação plausível dos deste trabalho.

Como pode ser constatado na Tabela 9, Vítor demonstrou um bom conhecimento a respeito dos conceitos que foram abordados, já que obteve avaliações menores do que quatro em apenas dois conceitos.

Possui uma excelente organização de ideias e um vocabulário que chama a atenção para uma pessoa de sua idade. No primeiro contato, antes do pré-teste, Vítor soube explicar detalhadamente seu processo de perda visual. Segundo ele, era portador de glaucoma já ao nascer, e passou por mais de uma cirurgia até ficar cego, aos sete anos de idade. Até então, já possuía deficiência visual, mas conseguia perceber formas e cores. Provavelmente, esta experiência ajuda a explicar suas notas altas nos desenhos, mas o exemplo da sua definição de girafa, comentado anteriormente neste capítulo, sugere que ainda havia algum espaço para a contribuição do recurso técnico do desenho em relevo.

É interessante ressaltar que Vítor não pareceu familiarizado com o material de desenho, pois apresentou uma certa dificuldade no manuseio da caneta e na realização de traçados no papel.

Como possuía um bom conhecimento dos conceitos, Vítor não dispunha de muito espaço para melhoria, uma vez que os critérios de avaliação obedeciam a uma escala de 1 a 5 . Entretanto, nas definições verbais em que obteve menos de 4 pontos na definição verbal e nos desenhos observou-se uma melhora. Em "trem" e "ilha" a definição verbal melhorou e o desenho de "leão" também foi melhor avaliado.

Estas ocorrências sugerem que as atividades com desenhos influenciaram a reorganização dos conhecimentos prévios que permitiram a ele chegar a definições mais 
precisas. Em relação aos desenhos que melhoraram, pode-se compreender que o sujeito adquiriu mais recursos para tornar suas representações ainda mais significativas.

Um bom exemplo disto foi o desenho de "montanha" no pós-teste, em que Vítor adicionou muito mais elementos ao desenho do que no pré-teste. Neste desenho, haviam animais como "carneiro montês, o puma e o bisão". Ainda que estes animais não façam parte do conceito de montanha, a prática do desenho evocou outros conceitos que fazem parte da rede de conhecimento do sujeito. Na perspectiva da visão teórica este é um dado interessante, pois permite conhecer as relações causais que "montanha" possui neste caso. Observa-se que a nota dos juízes não mudou em relação ao desenho (Tabela 9), pois o que era definidor permaneceu, e isto era o essencial. Mas uma observação pormenorizada demonstra que a maneira de representar o conceito não foi a mesma.

Se, por um lado, houve uma melhora, também ocorreu um prejuízo na representação gráfica de "árvore". Isto pode ser interpretado de duas maneiras. A primeira é que esta piora foi pontual, faltou algum detalhe nas definições e nos desenhos que o sujeito deixou passar naquele momento. A segunda é que o sujeito ainda precisava integrar a nova experiência, obtida pelo treinamento, ao seu repertório. Entendendo que o número de sessões de treinamento foi pequeno, e que cada desenho não pode ser suficientemente revisto para a fixação de suas características, é de se esperar um certo conflito no momento escolher as informações que serão utilizadas na representação do conceito.

Bruno é um adolescente de 15 anos, que demonstrou ter experiência com a utilização de desenhos. Logo que o material lhe foi apresentado, desenhou com convicção. No entanto, utilizava traços muito fortes, que chegavam a rasgar o papel. Por exemplo, para fazer uma linha, Bruno passava a caneta sobre o papel muitas vezes, e chegava a se confundir para integrar os diferentes detalhes dos desenhos. Por isso, um dos objetivos do treinamento foi reorientar o uso do material, de forma que os desenhos pudessem ser melhor utilizados e compreendidos por ele. Houve melhora na representação gráfica de alguns conceitos, mas ocorreu um pior desempenho de outros, como pode ser visto na Tabela 10.

Bruno demonstrou gostar muito da atividade de fazer desenhos e, por mais de uma vez, ficou empolgado com seus resultados durante o treinamento. No entanto, era o que mais faltava às sessões, por isso o espaço entre uma sessão de treinamento e outra foi grande, 
chegando a ser de três semanas. Talvez isto explique o baixo desempenho verificado na avaliação dos desenhos.

Nas definições verbais, Bruno demonstrou ter um bom conhecimento dos conceitos, sem muito espaço para melhora. Apenas nos conceitos "montanha" e " ilha" obteve notas baixas no pré-teste. Em relação à "montanha", tanto a definição verbal como o desenho melhoraram significativamente, principalmente o desenho. A definição verbal de "ilha" não melhorou, mas obteve progresso em sua representação gráfica.

Estes dois conceitos podem ser esclarecedores a respeito do processo de Bruno, por isso vale a pena uma análise mais particularizada. Em concordância com a hipótese de que a experiência visual de terceiros é uma fonte importante para a formação de alguns conceitos, Bruno apresentou dificuldade em definir os dois conceitos em questão, pois apenas tinha condições de reproduzir os que ouvia dos colegas ou nos meios de comunicação. O problema, é que o sujeito apreendeu apenas os atributos característicos destas informações. Talvez as definições tenham sido transmitidas desta maneira. Portanto, é importante que aqueles que descrevem as informações visuais para as pessoas cegas enfatizem os atributos definidores dos conceitos.

Dentre os sujeitos que participaram desta pesquisa, Daniela foi aquela a quem foram atribuídas as menores notas de desempenho nas definições verbais, embora suas notas no desenho tenham sido razoáveis de maneira geral. Durante as cinco sessões da pesquisa, a maior dificuldade apresentada por Daniela foi na comunicação verbal. Falava muito baixo, na maioria das vezes com a cabeça abaixada, o que dificultou bastante a compreensão do locutor. Por vezes, desviava perdia-se conversas ou então estabelecia relações com outros assuntos que não ficaram claros para o pesquisador.

Um dos fatores que pode explicar este comportamento é a família extremamente protetora, algo comum às pessoas com qualquer tipo de deficiência. Apesar de ter 12 anos, a fala de Daniela possui características infantis. Além disso, está cursando o segundo ano do Ensino Fundamental I, o que sugere uma escolarização tardia ou de percurso irregular.

Entretanto, Daniela apresentou a evolução mais significativa nas definições verbais, comparada aos outros sujeitos, como pode ser verificado na Tabela 11 e na Figura 7. No conceito "girafa" por exemplo, melhorou sua definição verbal em 106,2\%. Aliás, todas as 
definições verbais apresentaram progresso significativo, exceção feita a ilha, que permaneceu em um ponto.

A partir deste resultados pode-se afirmar que Daniela tem grande capacidade e disposição para o aprendizado, mas as experiências que reuniu até o momento não lhe proporcionaram condições de desenvolver todo o seu potencial. Isto pode ter ocorrido por várias razões, que escapam ao alcance deste trabalho, o que não impede a formulação de algumas hipóteses. Conforme visto no Capítulo 1, a potencialidade de desenvolvimento das pessoas cegas pode ser prejudicada pelo preconceito e pela baixa expectativa que se tem em torno destas pessoas (Nunes e Lomônaco, 2010). Portanto, pode-se inferir que Daniela tem sido tratada, de maneira geral, com baixas expectativas em relação às suas possibilidades de aprendizagem; ou privada de relações genuínas, nas quais pode ser vista sem o véu da deficiência.

Estas hipóteses não devem ser direcionadas apenas para o esclarecimento do caso de Daniela, uma vez que outros fatores importantes puderam ser considerados, mas servem como sugestões para futuros trabalhos que se proponham a investigar a influência do preconceito sobre a aprendizagem de pessoas com deficiência visual.

Rogério, assim como Vítor, é cego adventício. É portador de deficiência visual desde o nascimento, mas adquiriu cegueira no começo do ano em que este trabalho foi realizado. Com 12 anos, está apenas no $3^{\circ}$ ano do Ensino Fundamental I. Como sua perda de visão foi gradativa e acompanhada pela professora especialista, foi ensinado a utilizar o Braille e outros recursos específicos antes da perda total das funções visuais.

Apesar de ter experiência visual, o desempenho de Rogério nos desenhos não foi notoriamente melhor do que o dos demais sujeitos, ao contrário do que se poderia pensar. Isto sugere que, apesar de importante, a experiência visual prévia não foi, exatamente, o fator mais decisivo para a formação de conceitos precisos. Nas definições verbais o desempenho de Rogério foi inicialmente bom e melhorou significativamente após o treinamento.

Rogério é um garoto muito comunicativo, o que pode ter facilitado a melhoria das definições verbais, uma vez que este recurso foi bastante utilizado nas sessões de treinamento. Além disso, trata-se de um rapaz relata relações sociais muito significativas, com os irmãos e outros rapazes do bairro no qual reside. De acordo com seus relatos, Rogério participa de todas as atividades e brincadeiras com seus irmãos. Como defendido por Oliveira e 
Bomtempo (2009), a liberdade para brincar e explorar o ambiente favorece o desenvolvimento cognitivo e, consequentemente, a formação de conceitos.

Uma vez que Rogério apresentou melhoria na maioria das definições verbais, exceção feita aos conceitos "girafa" e "prédio", pode-se entender que o recurso técnico foi válido para o aprimoramento dos conceitos. Entretanto, a avaliação dos desenhos aponta para um pior desempenho na representação de metade dos conceitos estudados. Isto sugere que o procedimento não atinge as representações gráficas na mesma maneira que as representações verbais, ao contrário do que poderia ser pensado intuitivamente, já que a ênfase da técnica ocorreu na produção de desenhos. Uma hipótese que pode elucidar esta aparente contradição é que durante a produção de desenhos o sujeito consegue apoiar-se em atributos físicos tateáveis que lhe permitem compreender melhor o exemplo, mesmo que estes não sejam óbvios para os videntes. Isto pode ser verificado nas definições e desenhos de "árvore". Apesar de representar o conceito melhor no pré-teste, no pós Rogério utilizou mais atributos para representar o conceito. Utilizou, inclusive, as relações entre este conceito e o conceito de "montanha", o que demonstra sua capacidade de articular este conceito com outros.

Fábio é o mais velho do grupo, com 17 anos. Trata-se de uma rapaz comunicativo, apesar da timidez. De início apresentou bom domínio dos conceitos trabalhados. Ainda assim, conseguiu melhorar o seu desempenho na maioria das definições verbais. Embora tenha melhorado bastante sua representação gráfica de "leão" (207\%) e de "girafa" (43,5\%), o seu desempenho nos desenhos foi inferior ao desempenho nas definições verbais.

Em resumo, ainda que, como grupo, o desempenho dos sujeitos no desenho não tenha sido homogêneo, é razoável sugerir que o instrumento parece ter colaborado para a aprendizagem destes sujeitos, não obstante suas diferenças individuais.

Um outro ponto que merece destaque é o de que a utilização dos desenhos em relevo demonstrou possibilidades interessantes para a apreensão dos atributos definidores dos conceitos tanto para os sujeitos com cegueira congênita (Daniela, Bruno e Fábio) como para os portadores de cegueira adquirida (Vítor e Rogério).

Em relação aos conceitos, não se observaram grandes diferenças no tocante ao grau de dificuldade para sua aprendizagem, tal como pode ser constatado pela amplitude das médias, que foi de aproximadamente 1 ponto. É provável que tal resultado seja uma consequência do fato de que todos os conceitos trabalhados partilham de vários aspectos comuns. Por exemplo: 
são todos conceitos utilizados pelos sujeitos na vida diária, passíveis de serem aprendidos independentemente do ensino formal e são frequentemente utilizados na linguagem popular.

Embora existam definições científicas para todos os conceitos empregados nesta pesquisa, as teorias ingênuas (Keil, 1989) que os sujeitos possuem são suficientes para sua adaptação ao ambiente. Frequentemente os sujeitos utilizaram teorias desta natureza para definir os conceitos trabalhados. Por exemplo, em "nuvem", se utilizaram do processo de evaporação da água como explicação de sua formação, ou como acontecem os trovões. No caso dos conceitos "girafa" , "leão" e "árvore", se utilizaram de conceitos como "ser-vivo", "animal" e "planta" para defini-los. Ou seja, estes exemplos sugerem que os conceitos que compõe este estudo estão sedimentados em teorias ingênuas apresentadas pelos sujeitos.

Outra característica de similaridade entre os conceitos trabalhados com os sujeitos é que todos possuem atributos físicos e são "concretos". Os atributos físicos destes conceitos, entretanto, não são tateáveis por completo e nem por igual. Um prédio ou um trem podem ser tateáveis de muitas maneiras, mas não se pode percebê-los em toda sua extensão por meio do tato. Uma girafa pode ser tocada, mas é pouco provável que isto aconteça, por tratar-se de um animal selvagem de grandes proporções. Sendo assim, é necessário que a pessoa cega utilize outras pistas para a formação destas representações mentais. Neste aspecto a linguagem, a audição e o olfato são essenciais. Bruno, por exemplo, menciona o cheiro da estação de metrô para definir "trem"; enquanto Fábio afirma que não sabia o que era uma ilha até os 12 anos de idade, quando resolveu perguntar para seus colegas.

Finalmente, a partir das considerações e hipóteses discutidas ao longo deste capítulo, cabe analisar o resultado que, na opinião do autor deste trabalho, parece ter o mais intrigante, qual seja: Por quê as definições verbais apresentaram melhorias mais significavas do que os desenhos na representação dos conceitos?

Esse resultado em si é contra-intuitivo, pois uma vez que os sujeitos realizaram um treinamento com desenhos, seria de se esperar que a qualidade das representações gráficas melhorassem.

Sem a pretensão de responder à esta pergunta forma inquestionável, mas apenas de apontar um caminho para a compreensão deste resultado, parece razoável formular a hipótese de que os desenhos permitiram aos sujeitos confrontarem-se com os atributos definidores dos conceitos. Ainda que os sujeitos tivessem conhecimento de tais atributos, os desenhos 
permitiram-lhes conhece-los de uma forma diferente da anteriormente, qual seja, pelo tato. Daniela, por exemplo, sabia que uma girafa era um animal grande e com quatro patas. Depois do treinamento com os desenhos, afirmou que uma girafa tem patas, atrás, e rabo e na frente é as patas do braço e o pescoço grande (sic). A experiência com a representação gráfica do conceito permitiu a Daniela reorganizar os atributos que já possuía, e agrupa-los com os novos que foram descobertos no desenho.

Algo semelhante ocorreu com Fábio no conceito "árvore". Antes do trabalho com desenhos, ele baseava-se nos atributos áspero, galhos e de onde se tira o papel. Após o treinamento, parte da definição verbal de Fábio foi a seguinte: $O$ tronco dela é meio encurvado né, e ela tem um galho né, que pode também ter... Pode ter folhas, né, nos galhos, né. Além disso, mencionou as raízes, localizando-as, espacialmente, embaixo da árvore, no chão. Ao comparar as respostas percebe-se que o conceito "galho" continuou fazendo parte da definição, mas foi ligado a outros conceitos, que possibilitaram a formação de atributos definidores do conceito "árvore".

Um terceiro exemplo pode é o de Vítor, em relação ao conceito "trem". Na definição do pré-teste utilizou os atributos "rodas", "veículo" e "apito alto", na definição. No pós-teste Vítor adicionou "vagão", "locomotiva", "fumaça" e outros. Ao que parece, os desenhos forneceram mais atributos à representação mental precedente, que já era constituída de alguns atributos definidores.

Em resumo, o recurso técnico de desenhos em relevo parece ter sido útil no ensino/aprendizagem de conceitos de pessoas cegas, uma vez que tem o potencial de facilitar a percepção de atributos que não são de fácil apreensão pelos seus sentidos.

Todavia, em função do reduzido número de sujeitos que participaram da pesquisa, do pequeno número de sessões de treinamento entre o pré e pós-teste, do fato de que todos os sujeitos eram originários de uma mesma instituição de ensino situada numa única cidade de brasileira de um único estado brasileiro, os resultados do presente trabalho não são passíveis de uma ampla generalização. Na verdade, em face das limitações consideradas é preciso muita cautela na generalização dos mesmos para outros tipos de sujeitos, instituições e regiões geográficas. Assim sendo, outros estudos que levem em conta as limitações assinaladas serão muito bem vindos. 
$\mathrm{O}$ autor ficaria particularmente satisfeito se os incipientes resultados deste trabalho pudessem servir como inspiração para a realização de outras pesquisas que pudessem superar as limitações deste estudo. 


\section{REFERÊNCIAS $^{7}$}

Adorno, T. W. (2006). Educação e emancipação (4a ed.). São Paulo: Paz e Terra.

Amaral, L. A. (1998). Sobre crocodilos e avestruzes: falando de diferenças físicas, preconceitos e sua superação. In J. G. Aquino (Org.), Diferenças e preconceito na escola: alternativas teóricas e práticas (pp. 11-30). São Paulo: Summus.

Amiralian, M. L. T. M. (1997). Compreendendo o cego: uma visão psicanalítica da cegueira por meio de Desenhos-Estórias. São Paulo: Casa do Psicólogo.

Amiralian, M. L. T. M., Pinto, E. B., Ghirardi, M. I. G., Lichtig, I., Masini E. F. S. \& Pasqualin, L. (2000). Conceituando deficiência. Revista de Saúde Pública, 34(1), 97-103. Recuperado em 30 de janeiro, 2010, de http://www.scielo.br/pdf/rsp/v34n1/1388.pdf

Amiralian, M. L. T. M. (2009). Comunicação e participação ativa: a inclusão de pessoas com deficiência visual. In M. L. T. Amiralian (Org), Deficiência visual: perspectivas na contemporaneidade (pp. 19-38). São Paulo: Vetor.

Batista, C. G. (2005). Formação de conceitos em crianças cegas: questões teóricas e implicações educacionais. Psicologia: Teoria e Pesquisa, 21 (1), 007-015.

Belsky, J. (2010). Desenvolvimento humano: experenciando o ciclo da vida (2a ed.). Porto Alegre: Artmed.

Berger, K. S. (2003). O desenvolvimento da pessoa: da infância à terceira idade (5 ${ }^{\mathrm{a}}$ ed.). Rio de Janeiro: LTC.

Bueno, J. G. (1993). Educação especial brasileira: integração/segregação do aluno diferente. São Paulo: Educ.

${ }^{7}$ De acordo com o estilo APA - American Psychological Association. 
Bueno, J. G. (2008). As políticas de inclusão escolar: uma prerrogativa da educação especial? In J. G. Bueno, M. G. Mandes, \& R. A. Santos (Orgs.), Deficiência e escolarização: novas perspectivas de análise (pp. 43-63). Araraquara; Brasília, SP; DF: Junqueira\&Marin; CAPES.

Cardeal, M. (2009). Ver com as mãos: a ilustração tátil em livros para crianças cegas. Dissertação de Mestrado, Universidade do Estado de Santa Catarina, Florianópolis. Recuperado em 27 de novembro de 2010, de http://ppgav.ceart.udesc.br/turma3_2007/dissertacoes/marcia_cardeal.pdf

Cecatto, R. B. (2006). Atualização sobre os aspectos médico-legais da inclusão da pessoa com deficiência física no mercado de trabalho. In A. L. Senney, L. I. Z. Mendonça, B. B. G. Schlecht, E. F. Santos, E. C. Macedo (Orgs.) Neuropsicologia e Inclusão: tecnologias em (re)habilitação cognitiva (p. 27-41). São Paulo: Artes Médicas.

CORDE (2007). Convenção Sobre os Direitos da Pessoas com Deficiência: protocolo facultativo à Convenção Sobre os Direitos das Pessoas com Deficiência. Brasília: Coordenadoria Nacional para Integração da Pessoa Portadora de Deficiência. Recuperado em 04 de novembro de $2010, \quad$ de http://portal.mec.gov.br/index.php?option=com_content\&view=article\&id=12716\&Itemid $=863$

Crochík, J. L. (2006). Preconceito, indivíduo e cultura (3a ed.). São Paulo: Casa do Psicólogo.

Crochík, J. L. (2009). Preconceito e cultura. In M. L. T. M. Amiralian (Org.), Deficiência visual: perspectivas na contemporaneidade (pp. 39-56). São Paulo: Vetor.

Espinosa, M. A. \& Ochaíta E. (2004). Desenvolvimento e intervenção educativa nas crianças cegas ou deficientes visuais. In C. Coll, A. Marchesi \& J. Palácios (Orgs), Desenvolvimento psicológico e Educação: transtornos do desenvolvimento e necessidades educativas especiais (2a ed., Vol. 3, pp. 151-170). Porto Alegre: Artmed.

Ferreira, J. R. (1994). A exclusão da diferença. São Paulo: Editora Unimep.

Flavell, J. F. (1976). O desenvolvimento de conceitos. In P. H. Mussen (Org.), Carmichael Psicologia da Criança (Vol. 6, pp. 1-13). São Paulo: EPU/EDUSP. 
Gazzaniga, M. S., Ivry, R. B., \& Mangnun, G. R. (2006). Neurociência cognitiva: a biologia da mente (2a ed.). Porto Alegre: Artmed.

Januzzi, G. M. (2004). A educação do deficiente no Brasil: dos primórdios ao início do século XXI. Campinas, SP: Autores Associados.

Keil, F. C. (1989). Concepts, Kinds and cognitive development. Cambrige, MA: MIT Press.

Lei n. 9.394, de 20 de dezembro de 1996. (1996, 23 de dezembro). Estabelece as Diretrizes e Bases da Educação Nacional. Recuperado em 04 de janeiro de 2011, de http://www.planalto.gov.br/ccivil_03/LEIS/L9394.htm

Lomônaco, J. F. B., Caon, C. M., Heuri, A. L. P. V., Santos, D. M. M. \& Franco, G. T. (1996). Do característico ao definidor: um estudo exploratório sobre o desenvolvimento de conceitos. Psicologia: Teoria e Pesquisa, 12(1), 51-60.

Lomônaco, J. F. B. (1997). A natureza dos conceitos: visões psicológicas. Tese de Livre Docência, Instituto de Psicologia, Universidade de São Paulo, São Paulo.

Lomônaco, J. F. B., Paula, F. V., Mello, C. B. \& Almeida, F. A. (2001). Desenvolvimento de conceitos: o paradigma das transformações. Psicologia: Teoria e Pesquisa, 17(2), 161-168.

Martins, J. S. (1997). Exclusão social e a nova desigualdade. São Paulo: Paulus.

Mittler, P. (2003). Educação inclusiva: contextos sociais. Porto Alegre: Artmed.

Masini, E. A. (1997). Intervenção educacional junto à pessoa com deficiência visual. In E. A. Masini, Becker, E., Pinto, E. B., Amaral, L. A., Kovács, M. J. \& Amiralian, M. L. T. M., Deficiência: alternativas de intervenção (pp. 73-92). São Paulo: Casa do Psicólogo.

Mazzotta, M. J. (1982). Fundamentos da educação especial. São Paulo: Pioneira. 
Namo, D. (2007). A percepção e participação parental em relação ao Serviço de Salas de Recursos para Alunos com Deficiência Visual. Tese de Doutorado, Faculdade de Educação, Universidade de São Paulo, São Paulo.

Nunes, S. S. (2004). Desenvolvimento de conceitos em cegos congênitos: caminhos de aquisição do conhecimento. Dissertação de Mestrado, Instituto de Psicologia, Universidade de São Paulo, São Paulo.

Nunes, S. S., Lomônaco, J. F. B. (2008). Desenvolvimento de conceitos em cegos congênitos: caminhos de aquisição do conhecimento. Psicologia Escolar e Educacional, 12(1), 119138.

Nunes, S. S., Lomônaco, J. F. B. (2010). O aluno cego: preconceitos e potencialidades. Psicologia Escolar e Educacional , 14(1), 55-54.

Oliveira, R. F. C. (2009). Desbraillização: realidade e perspectivas. In M. L. T. Amiralian (Org), Deficiência visual: perspectivas na contemporaneidade (pp. 169-178). São Paulo: Vetor.

Oliveira, V. B., \& Bomtempo, E. (2009). O processo lúdico e a formação da identidade social. In M. L. Amiralian, Deficiência Visual: perspectivas na contemporaneidade (pp. 117-129). São Paulo: Vetor.

OMS. Centro Colaborador da OMS para a Famíla de Classificações Internacionais (Org.). (2008). CIF - Classificação Internacional de funcionalidade, incapacidade e saúde. São Paulo: EDUSP.

Ormelezi, E. M. (2000). Os caminhos da aquisição do conhecimento e a cegueira: do universo do corpo ao universo simbólico. Dissertação de Mestrado, Faculdade de Educação, Universidade de São Paulo, São Paulo. Recuperado em 15 de dezembro, 2009, de Biblioteca Digital de Teses e Dissertações da Universidade de São Paulo: www.teses.usp.br

Palácios, J. (2004). Psicologia evolutiva: conceito, enfoques, controvérsias e métodos. In C. Coll, J. Palácios, \& A. Marchesi (Orgs), Desenvolvimento psicológico e educação (2a ed., Vol. 1, pp. 13-52). Porto Alegre: Artmed. 
Patto, M. H. (2008). Políticas atuais de inclusão escolar: reflexão a partir de um recorte conceitual. In J. G. Bueno, G. M. Mendes, \& R. A. Santos (Orgs), Deficiência e escolarização: novas perspectivas de análise (pp. 25-42). Araraquara ; Brasília, SP ; DF: Junqueira\&Marin; CAPES.

Resnikoff, S. et al. (2004). Global data and visual impairment in the year 2002. Bulletin of the World Health Organization, 82(11). Recuperado em 28 de novembro de 2009, de http://www.who.int/bulletin/volumes/82/11/en/844.pdf

Rosch, E. (1978). Principles of categorization. In E. Rosch \& B. B. Lloyd (Org.), Cognition and categorization (pp. 27-48). Hillsdale, N. J.: Erlbaum

Salomão, S., Mitsuhiro, M. R., \& Belfort Jr., R. (2009). Visual impairment and blindness: an overview of prevalence and causes in Brazil. Anais da Academia Brasileira de Ciências, 3 (81), 539-549. Recuperado em 03 de dezembro de 2010, de http://www.scielo.br/scielo.php?script=sci_arttext\&pid=S0001-37652009000300017

Siaulys, M. O. C. (2005). Brincar para todos. São Paulo: Laramara.

Toledo, C. C., Paiva, A. P., Camilo, G. B., Maior, M. R., \& Leite, I. C. (2010). Detecção precoce de deficiência visual e sua relação com o rendimento escolar. Rev. Associ. Med. Bras., 56 (4), 415-419. Recuperado em 10 de dezembro de 2010, de http://www.scielo.br/pdf/ramb/v56n4/13.pdf 
ANEXO A

FICHAS DE IDENTIFICAÇÃO DOS PARTICIPANTES

Nome:

Idade:

Sexo:

Escolaridade:

Tipo de deficiência visual:

Escola:

Utiliza o Braille para escrita:

Observações: 
ANEXO B

RÉPLICA DOS MODELOS DE DESENHOS EM RELEVO

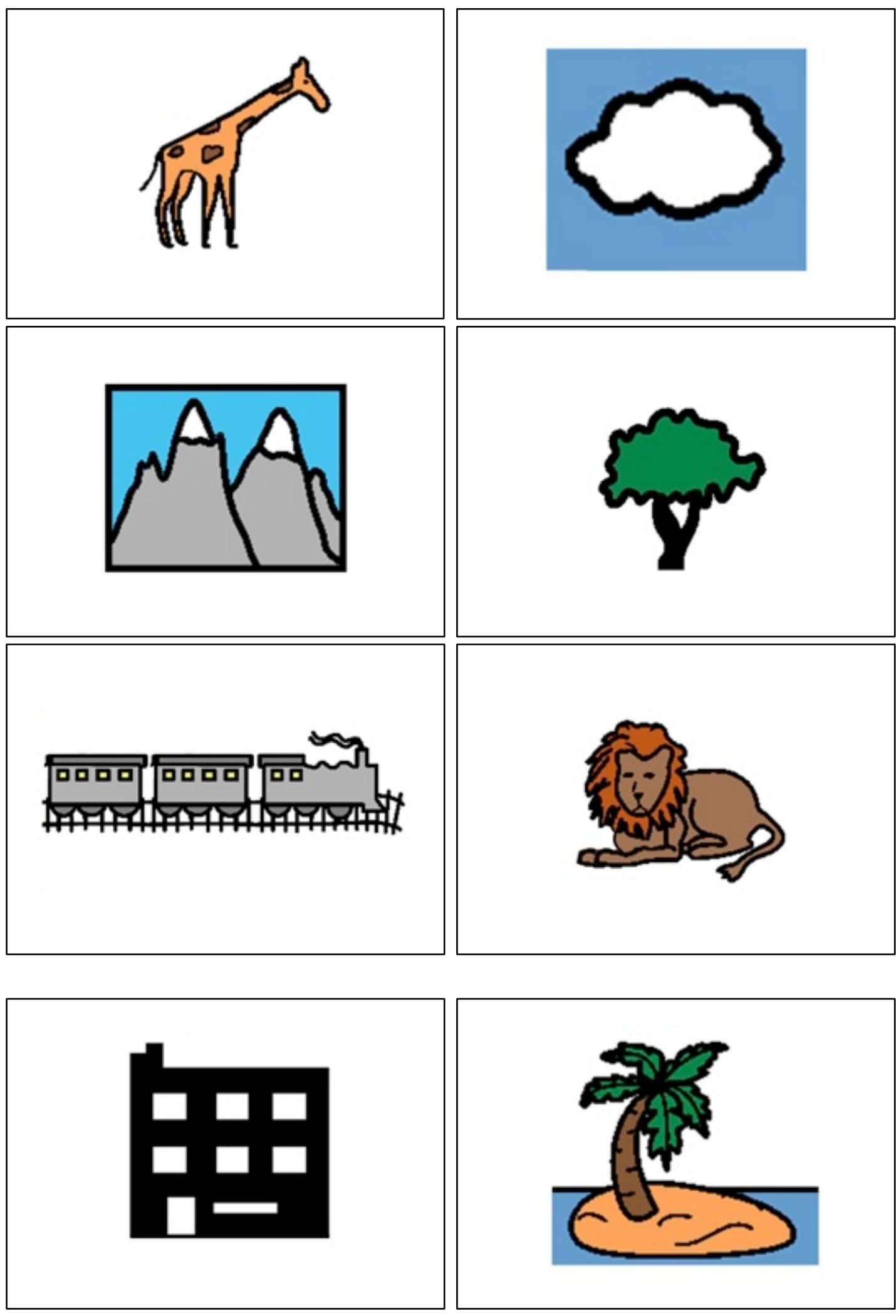




\section{ANEXO C \\ TERMO DE CONSENTIMENTO LIVRE E ESCLARECIDO}

Prezado(a) Senhor(a),

Meu nome é Caio Parada Cabral, sou psicólogo, professor das Faculdades Metropolitanas Unidas (FMU) e do Instituto Sumaré de Educação Superior, e aluno do Curso de Pós-graduação em Psicologia Escolar e do Desenvolvimento Humano (nível - Mestrado) do Instituto de Psicologia da Universidade de São Paulo. Estou realizando uma pesquisa com o objetivo de compreender como a utilização de desenhos em relevo contribui para aprendizagem de conceitos em crianças cegas e solicito a sua colaboração.

Esta pesquisa consiste em três etapas: pré teste, treinamento para uso do desenho e pós teste. Na primeira, o pesquisador irá investigar o conhecimento prévio que a criança possui a respeito de alguns conceitos, que serão expostos verbalmente e em desenho. A criança também será solicitada a desenhar exemplos do conceito, utilizando a punção e reglete ou um desenhador. Cada criança será entrevistada individualmente e terá a duração de 30 minutos.

A etapa do treinamento será realizada em grupo, envolve a familiarização da criança com a utilização do desenho em relevo para a representação de conceitos, começado pelos mais concretos - como um círculo ou um objeto simples conhecido pela criança - até os mais abstratos. Poderão ser realizados até 5 encontros com as crianças, dependo do tempo que cada uma leva para dominar o uso do instrumento.

No pós teste as crianças serão reavaliadas em relação aos conceitos apresentados na primeira etapa da pesquisa e mais alguns que não foram apresentados na primeira etapa.

Todas as etapas da pesquisa serão gravadas em áudio e vídeo, mediante sua autorização e da instituição. O material gravado será utilizado para uma análise mais apurada dos resultados e não será divulgado de maneira alguma.

A participação da criança é gratuita e voluntária. Não haverá nenhum ônus para a criança, para sua família ou para a escola/instituição. É também possível que a criança deixe de fazer parte da pesquisa a qualquer momento, sem prejuízo algum, se ela, a escola/instituição ou seus responsáveis assim desejarem.

A pesquisa poderá ser publicada, mas não será divulgado nenhum dado que possibilite a identificação da criança ou da escola/instituição, sendo apresentados apenas os resultados gerais da pesquisa. 
Se quiser esclarecer alguma dúvida, meus telefones são: (11) 8426-5241 e 5563-5906 e o endereço do meu trabalho: Avenida Santo Amaro, 1239, Vila Nova Conceição. São Paulo, SP. CEP: 04506-000. Telefone (11) 3040-3400. Curso de graduação em psicologia. O endereço do Comitê de Ética em Pesquisa com Seres Humanos do Instituto de Psicologia da Universidade de São Paulo: Av. Prof. Mello Moraes, 1721, Bloco G, sala 22, Cidade Universitária. São Paulo, SP. Telefone: (11) 3097-0529.

Desde já agradeço a sua atenção,

Data

\section{Caio Parada Cabral}

Autorização para a realização da pesquisa:

$\mathrm{Eu}$ , responsável pelo menor , declaro que entendi os objetivos da minha participação na pesquisa e concordo em participar.

Data Assinatura 


\section{ANEXO D \\ TRANSCRIÇÃO ENTREVISTAS E RÉPLICA DOS DESENHOS REALIZADOS PELOS SUJEITOS}

\section{Entrevista Pré-teste: Vítor}

E: Pronto para começar?

V: Pronto!

E: Bom, eu gostaria de verificar o que você conhece a respeito de algumas coisas. Para isto vou fazer algumas perguntas, mostrarei alguns desenhos feitos em pontos e pedirei que você faça alguns desenhos utilizando os pontos em alto relevo. Não se preocupe em errar ou acertar, quero apenar que você me mostre como você faz, certo?

V: Tudo bem.

E: Então, primeiro as perguntas.

$\mathrm{V}$ : Perguntas.

E: Vítor, você sabe me dizer o que é uma girafa?

V: Girafa é um animal pescoçudo?

E: Pode ser. O que mais?

V: É um animal da África e Selvagem, ela é bem grande e só isso que eu sei.

E: É um animal da África...

$\mathrm{V}$ : E ela come folhas das copas das árvores.

E: Que legal. Onde você aprendeu isso?

$\mathrm{V}$ : Eu vi na tevê.

E: Você viu na tevê?

V: É.

E: Você já foi no Zoológico?

V: Já, uma vez.

$\mathrm{E}: \mathrm{E}$ te mostraram a girafa?

$\mathrm{V}$ : Eu não toquei na girafa, mas era uma girafa, eles disseram.

E: Que legal. E como que ela é?

$\mathrm{V}$ : O quê, a girafa? A girafa tem pintas. Tem pintas só que eu acho que aquilo que eu vi não era uma girafa, porque era bem menor que uma girafa.

$\mathrm{E}: \mathrm{O}$ que?

V: O bicho que eu vi lá. Parecia uma girafa, mas era menor.

E: Como você sabe que era menor?

$\mathrm{V}$ : Eles disseram.

E: Eles disseram?

V: É, eles disseram.

E: Então tá bom. Vamos pra outra. Você poderia me dizer o que é uma nuvem?

$\mathrm{V}$ : Nuvem?

E: Isso.

V: Nuvem é... São as gotas de água que se formam no céu.

E: Muito bem.

V: São gotas de água que evaporam e sobem para o céu e viram nuvens.

E: Muito bem. E você sabe mais ou menos como é uma nuvem?

V: Não. 
E: Não? Tá bom. I, você poderia me dizer o que é uma montanha?

$\mathrm{V}$ : Montanha?

E: Isso.

V: Uma montanha é como se fosse um escorregador.

E: Um escorregador?

V: Como se fosse. Bem eu já escalei o morro uma vez, foi difícil, foi super difícil, mas eu acabei chegando lá em cima. É difícil escalar uma montanha. Montanha é bem maior que o morro, bem maior.

E: Muito bom. E agora eu quero que você me diga o que é uma árvore.

V: Uma árvore?

E: Isso.

V: Uma árvore é uma coisa que você se planta com uma semente e tem o tronco enorme e folhas na copa, como eu disse antes, que a girafa comia as folhas das árvores, das copas das folhas das árvores.

E: Muito bem. Você já subiu em uma árvore?

V: Não...

E: Mas você queria subir, pela sua voz.

V: É...

E: Muito bem. Continuando. O que é um leão?

V: Leão?

E: É.

V: Leão é um felino.

E: Uhum.

V: É um felino, um animal bem perigoso e é um carnívoro.

E: Mais alguma coisa que você sabe sobre o leão?

V: Somente cinco dedos o leão tem, e é selvagem.

E: Tá certo. Vamos lá. Você poderia me dizer o que é um trem?

V: Um trem é um veículo de muitas rodas que eu nem sei quantas são. Muitas rodas e ele tem um apito alto. Ele passa, ele viaja pelo túnel, leva pessoas onde elas querem ir. Dá até pra viajar de trem, só que eu nunca viajei, de trem.

E: Legal. E onde você aprendeu?

$\mathrm{V}$ : Vi na tevê, também.

E: Também? Você aprende muitas coisas na tevê hein?

V: É.

E: Legal. Vamos lá. Me explica agora o que é um prédio.

V: Prédio?

E: Uhum.

V: Um monte de casas em cima das outras? Que moram pessoas?

$\mathrm{E}$ : Mais alguma coisa?

$\mathrm{V}$ : Não.

E: Você mora em prédio?

$\mathrm{V}$ : Não, moro em casa de quintal.

$\mathrm{E}$ : E você conhece alguém que mora em prédio?

$\mathrm{V}$ : Eu acho que sim.

E: Sim? Você já foi num prédio?

$\mathrm{V}$ : Já. Eu fui pra praia e fiquei num apartamento bem pequeno.

E: Hum... Era alto?

$\mathrm{V}$ : Era.

E: Então tá bom. E pra finalizar, queria saber se você pode me dizer o que é uma ilha.

V: Ilha? 
E: Isso.

V: Eu já fui numa ilha. Uma ilha é uma coisa que flutua em cima do mar, do oceano.

E: Uhum.

$\mathrm{V}$ : Eu já fui numa ilha, quando eu passei em cima da ponte minha mãe disse que o azul do mar que ficava lá era mó azulão mesmo.

E: Nossa. Você lembra o nome dessa ilha que você foi?

V: Ilha Comprida.

E: Ilha Comprida. Muito bem. Então tá bom. Olha, então essa parte acabou, de você me explicar.

$\mathrm{V}$ : Certo.

E: Agora vou te mostrar três desenhos.

V: Desenhos.

E: E eu gostaria que você tentasse identificar o que eles são.

V: Certo.

E: Deixa eu só pegar eles aqui. Vamos lá. Vou colocar em cima dessa prancha que você tá, tá bom?

V: Tá bom.

E: Esses desenhos são exemplos das coisas que eu perguntei se você conhecia, tá bom?

V: Tá.

E: E aí você tenta dizer o que é. Deixa eu colocar na posição correta. Vamos lá. Tá aqui. (mostra o papel)

(Vítor toca na folha)

E: Descreve pra mim o que você tá sentindo.

V: Tá, eu tô sentindo um retângulo grande e um monte de quadrados dentro.

E: Tá. Você sabe o que poderia ser isso? Dentro das coisas que eu falei?

V: E tem um retângulo... Você falou da ilha, da árvore, da girafa... Hum... É uma casa?

E: Parece.

V: Um prédio!

E: Isso. Muito bem hein!

$\mathrm{V}$ : Um prédio, você falou do prédio (toca no papel). Um, dois, três, quatro, cinco, seis. Seis casas.

E: Seis casinhas.

$\mathrm{V}$ : E tem a porta aqui de entrada.

E: Muito bem. O que você achou desse desenho?

V: Legal.

E: Vou mostrar outro agora. Dá a mão. Pronto. Esse é outro.

V: Tá, esse aqui é... Deixa eu ver. Aqui tem alguns círculos em baixo? Parecem círculos.

Círculos pela metade e em cima tem um reto como se fosse um retângulo.

E: Uhum.

V: Hum... É uma nuvem? São nuvens?

E: Não.

$\mathrm{V}:$ Hum...

E: Tá difícil? Se tiver muito difícil te conto o que é.

$\mathrm{V}$ : Um pouquinho.

E: Esse aí é um exemplo do trem.

$\mathrm{V}: \mathrm{Ah}$ !

E: Tá vendo esses círculos embaixo?

$\mathrm{V}$ : As rodas!

E: São as muitas rodas que você falou.

$\mathrm{V}$ : As rodas! 
E: Em cima são as partes do trem. E isso que você tá colocando aqui ó (coloca a mão de Vítor), é a fumacinha saindo da parte da frente.

$\mathrm{V}$ : É! Legal!

E: Legal?

V: Uhum.

E: Muito bem, vamos para o último agora.

$\mathrm{V}:$ O último.

E: Vê se você consegue descobrir o que é.

$\mathrm{V}$ : Esse é... (toca) Como se fosse... Aqui tem...

E: Pensa nas coisas que eu te perguntei, se você conhecia, vê se você assemelha a uma das coisas.

V: Árvore, girafa, trem, não. Árvore, girafa, trem, ilha, prédio, trem, é uma... É uma girafa?

Não, o pescoço seria maior. É uma árvore?

E: Aí tem uma árvore, muito bem. E embaixo?

$\mathrm{V}$ : Embaixo. Aqui, ó? Esse daqui?

E: É.

V: É uma nuvem?

E: Uma árvore fica em cima de uma nuvem?

V: Não. Desculpa.

E: E isso aqui, presta atenção aqui, nesse detalhe. (mostra o mar)

$\mathrm{V}$ : É o chão e a raiz. Não é? É o chão e a raiz.

E: Faria sentido, faria sentido.

V: Não é a raiz?

E: Não. Na verdade esse é o desenho de uma ilha.

V: Uma ilha.

E: Tem um pedaço aqui que seria a terra e essa linha aqui marca a água.

$\mathrm{V}: \mathrm{Ah}$ !

E: Tá vendo que ele está flutuando na água?

V: É, a árvore tá flutuando na água.

E: A árvore está em cima desse pedaço de terra que é a ilha. É que os desenhos de ilha geralmente são assim. Um círculo de terra com um coqueiro em cima.

V: Hum... Eu já vi, eu já vi um coqueiro numa ilha, numa praia.

E: Já viu? Então, praia tem coqueiro né? Muito bem.

$\mathrm{V}$ : E eles penduravam os búzios no coqueiro, a praia ficava toda vermelha. Ficava tipo um farol.

E: É mesmo?

V: É. Um farolzão.

E: Tá bom. Agora eu vou pedir pra você desenhar.

V: Desenhar.

E: Isso.

V: Lembra do bumerangue né?

E: Que bumerangue?

$\mathrm{V}$ : O bumerangue que eu pedi pra gente desenhar.

E: Ah, tá bom. Vamos fazer assim: o bumerangue fica por último. Deixa primeiro eu pedir os desenhos das coisas que a gente falou aqui e depois você faz o bumerangue. Toma o lápis pra você desenhar. Não aperta esse botão em cima senão cai a ponta dele, tá bom?

$\mathrm{V}$ : Esse botão aqui?

E: É. Se apertar cai a ponta.

$\mathrm{V}$ : Ah tá. 
E: Então das coisas que nós falamos, vamos começar pelas que você sentiu no desenho. E pra começar escolhe pela ilha, pela árvore ou pelo trem? Desculpa, ilha, prédio ou trem?

$\mathrm{V}: \mathrm{Eu}$ quero fazer um prédio.

E: Então vai.

(Vítor começa a desenhar)

V: Vamos ver... Seis janelas. A minha janela vai ficar meio que assim.

E: Tudo bem.

V. finaliza: É eu acho que foi.

E: Muito bem. Isso é um prédio? Só me explica. Aqui tão as janelas, e isso aqui é o que?

$\mathrm{V}$ : Essa é a porta, aí eu fiz aquele, tipo, aquele negócio que você fez assim em volta.

E: Tá bom, está ótimo.

E. vira a folha e toca.

E: Muito bem, eu gostei. Você quer como ficou?

V: Quero.

E: Gostou?

$\mathrm{V}:$ É, gostei.

E: Ficou bom. Então vamos lá. Vamos fazer mais um?

V: Vamos!

E: Vamos puxar, espera aí, deixa eu prender a folha, vamos lá, pode fechar. Você pode desenhar pra mim um trem?

$\mathrm{V}$ : E a ilha, né?

E: Isso.

$\mathrm{V}$ : Eu quero o trem. Posso usar sua régua pra fazer o trem?

E: O Trem? Pode.

(Vítor mede com os dedos o espaço que vai usar a régua) V: É, já dá.

E: Já dá?

V: Pra ter uma ideia.

E: Tá bom.

V: Vamos lá. (começa a desenhar)

V. (durante o desenho): É eu acho que deu.

V: A mãe do Rogério ficou brava ontem porque era pra vim hoje, aí ela veio ontem e ficou brava pra vim.

E: Como assim?

V: Ela ficou brava porque ontem a professora não era... Ficou aqui o dia todo, aí ela veio ontem e a porta tava fechada, ficou aí até as cinco, com a porta fechada.

E: Ah.

V. (desenhando): Sete. Sete rodas.

V: Você que fez esses desenhos?

E: Foi. Na verdade esses desenhos já são prontos, e eu só passo pro relevo, entendeu?

V: Hum, você só faz isso com lápis.

E: É.

V: Ó.

E: O que é isso que você tá desenhando?

$\mathrm{V}$ : Tô fazendo aqueles quadradinhos, vagões né?

E: Ah tá.

V. termina o desenho: Eu acho que ficou igualzinho.

E: Vamos ver. Vira aí pra você ver como ficou.

$\mathrm{V}$ : É, ficou mais ou menos igual.

E: Deixa eu ver. Olha, ficou muito legal. Explica pra mim o que você fez aqui, as rodas...

$\mathrm{V}$ : É, as rodas. 
E: Em cima tem os vagões, e esse aí em cima?

V: É a fumacinha.

E: Fumacinha, muito bem. Beleza.

V: Agora só falta ilha com coqueiro.

E: Deixa eu te dar mais uma folha.

V: Então, aí. Deixa eu ver de novo.

E: Deixo.

V: É que eu não me lembro dos detalhes, da parte da terra encaixada com o coqueiro.

E: Tá bom, vou pegar aqui. Pronto, tá aqui.

Vítor toca o desenho.

V: Só esse coqueiro que vai ficar difícil.

E: Se ficar muito difícil não precisa fazer, porque aí é a terra cercada sobre a água. Pode fazer só isso.

V: Só a árvore vai ficar difícil.

E: Tá bom, não precisa fazer a árvore, não.

Vítor termina: É eu acho que ficou igual.

E: Olha, ficou bem legal. Muito bom, muito bom mesmo. Obrigado viu. Ah, só quero que você me mostre o seguinte, qual é a parte da frente do trem.

$\mathrm{V}$ : Ah, a parte da frente.

E: Deixa eu ver, está aqui. Me mostra onde é a frente pra eu ver se eu entendi bem.

V: É, ó... A faísca tá saindo daqui, tá faltando uma parte aqui, essa deveria ser a frente né? (Aponta pra a parte direita do trem).

E: Agora vamos continuar com aqueles outras coisas que eu perguntei o que eram.

V: Quero fazer a girafa.

E: Vamos lá, já coloquei a folha.

V: Hum, pescoço bem comprido (desenhando).

V: Terminei. Vamos pra o leão.

E: Tudo bem. Deixa eu tirar essa folha aqui e colocar outra.

V: São todos animais. Gosto de ver animais da floresta na televisão.

E: Legal né! Já troquei a folha.

$\mathrm{V}$ desenha em silêncio.

V: Olha aí. Ficou bom?

E: Ótimo. Quer fazer outro?

$\mathrm{V}$ : A nuvem.

E: Já troquei a folha

, é só desenhar.

$\mathrm{V}$ desenha.

V: Pronto, essa foi rapidinho. Nem tinha muita coisa pra fazer.

E: Podemos fazer a montanha agora?

V: Vou fazer uma bem grande.

V: Vai ser difícil subir nessa montanha. Aqui está.

E: Ficou muito bom. Podemos fazer o último?

V: Qual é?

$\mathrm{E}: \mathrm{A}$ árvore.

V: Então dá aí.

$\mathrm{V}$ desenha em silêncio.

V: Uhhhhhuu, terminei tudo!

E: Aqui? Agora você pode fazer seu bumerangue.

$\mathrm{V}$ : Um bumerangue.

E: Pode fazer. 
$\mathrm{V}$ : Eu fiz um cata-vento agora.

E: Você fez um cata-vento agora aí?

V: É.

E: Deixa eu ver.

V: Ó.

$\mathrm{E}:$ Aqueles de segurar?

V: É

E: Que o vento gira?

V: É.

E: Nossa, faz tanto tempo que eu não vejo um desse. Você tem?

$\mathrm{V}$ : Eu tenho um, só que não tem a caixinha pra fazer ele girar.

$\mathrm{E}$ : Ah, muito bem. Você quer ficar com esse?

V: Quero.

E: Obrigadão viu? Por hoje é só. 
Desenhos Pré-teste: Vítor

\section{Girafa}

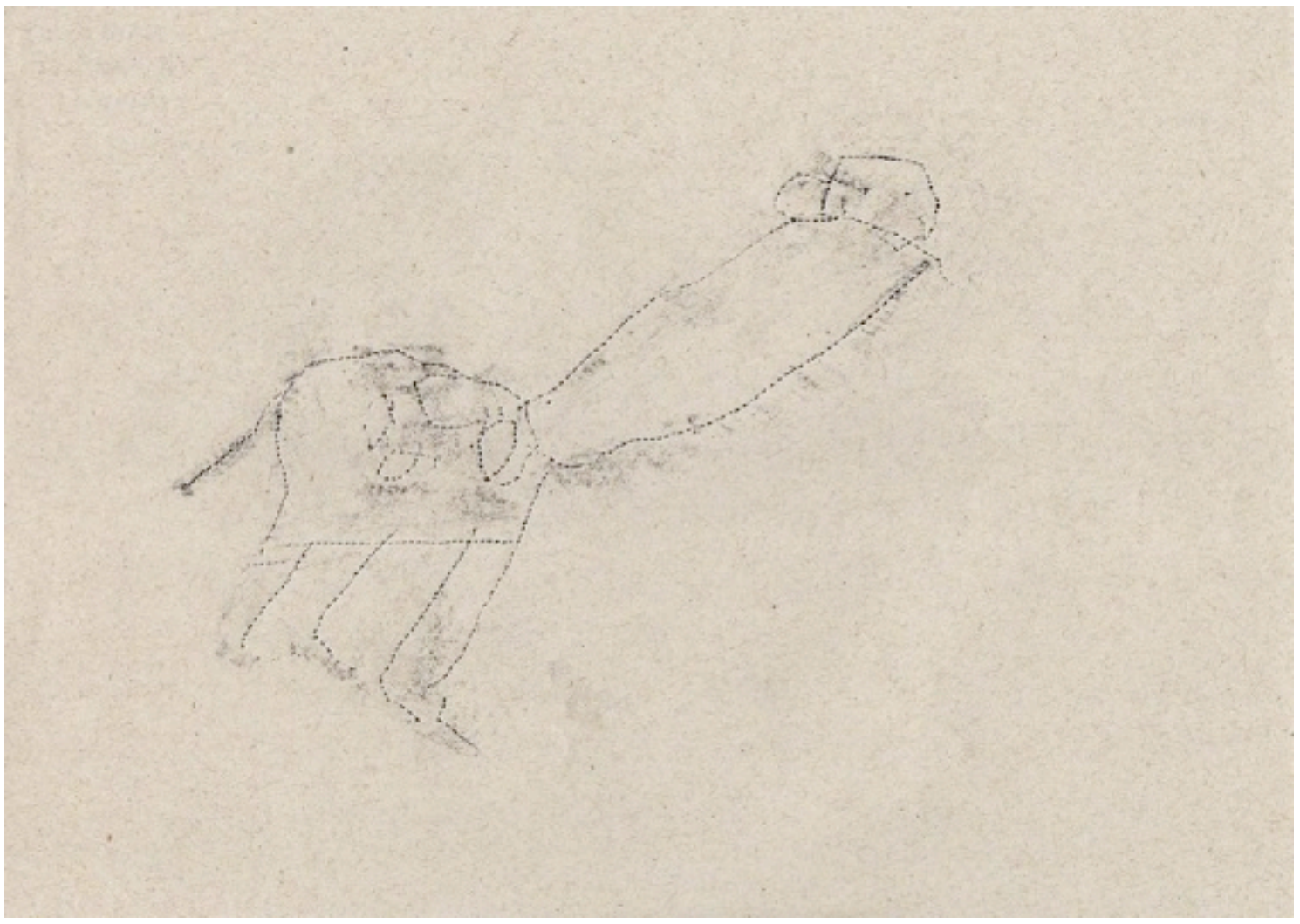

Nuvem

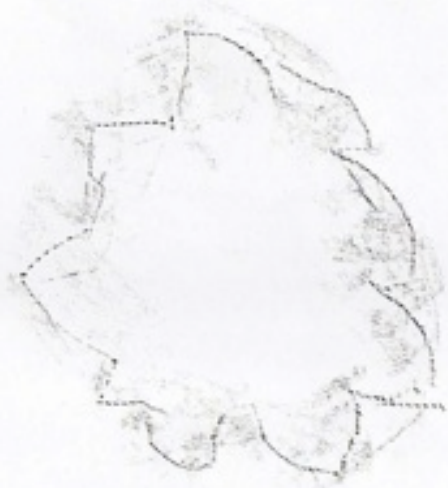


Montanha

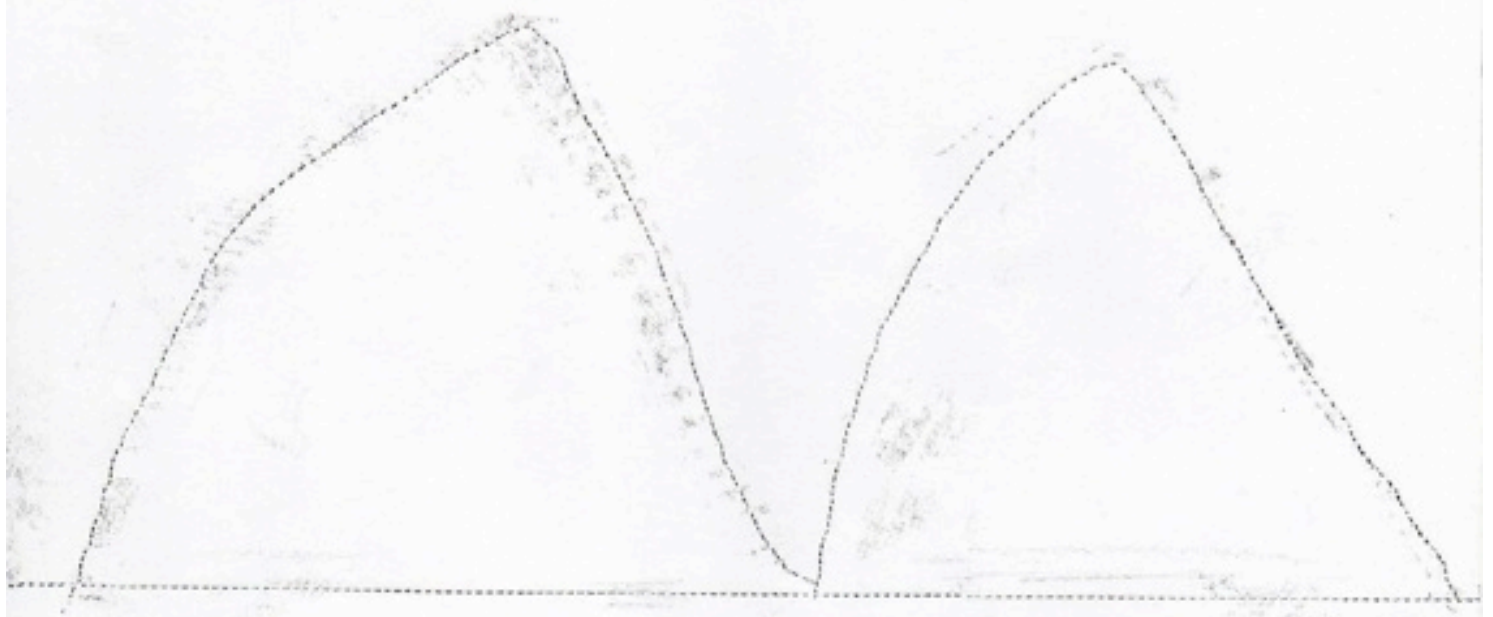

Árvore

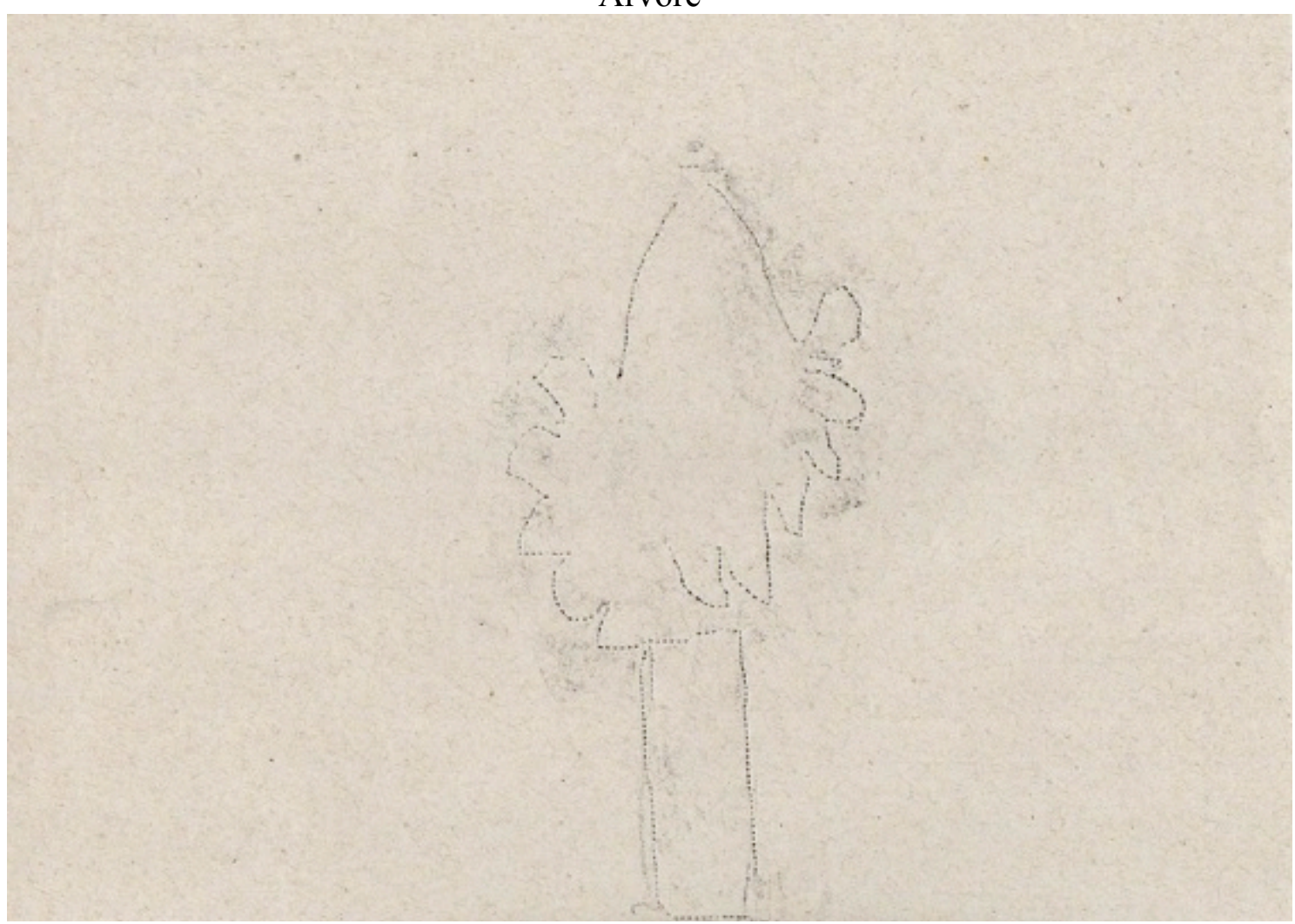


Trem

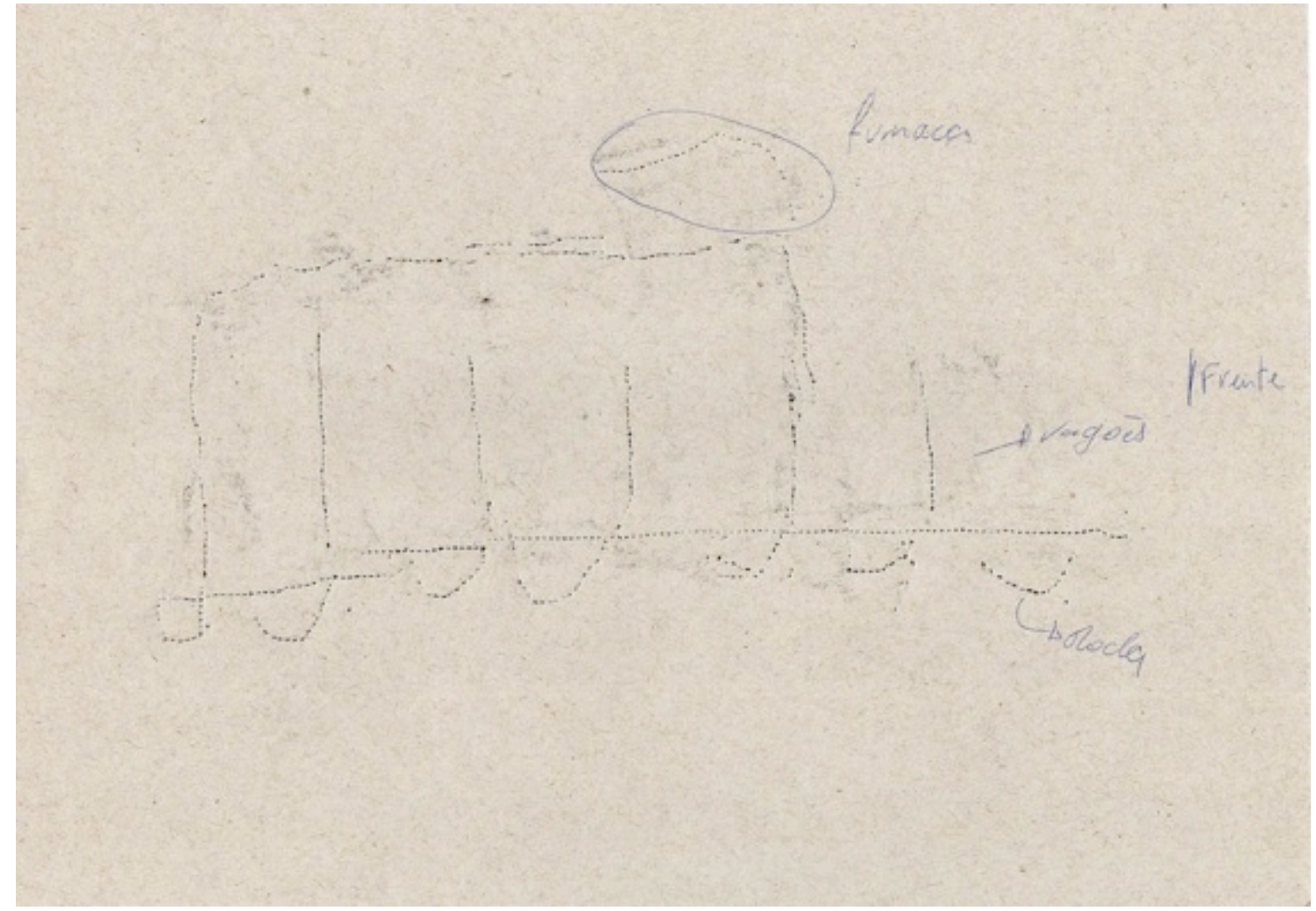

Leão

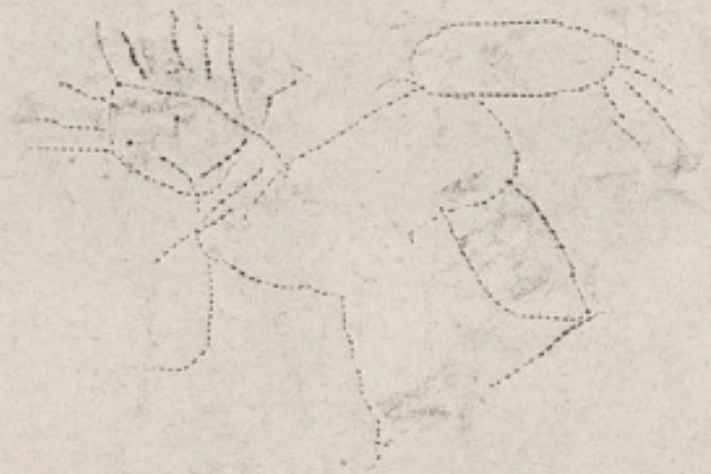


Prédio

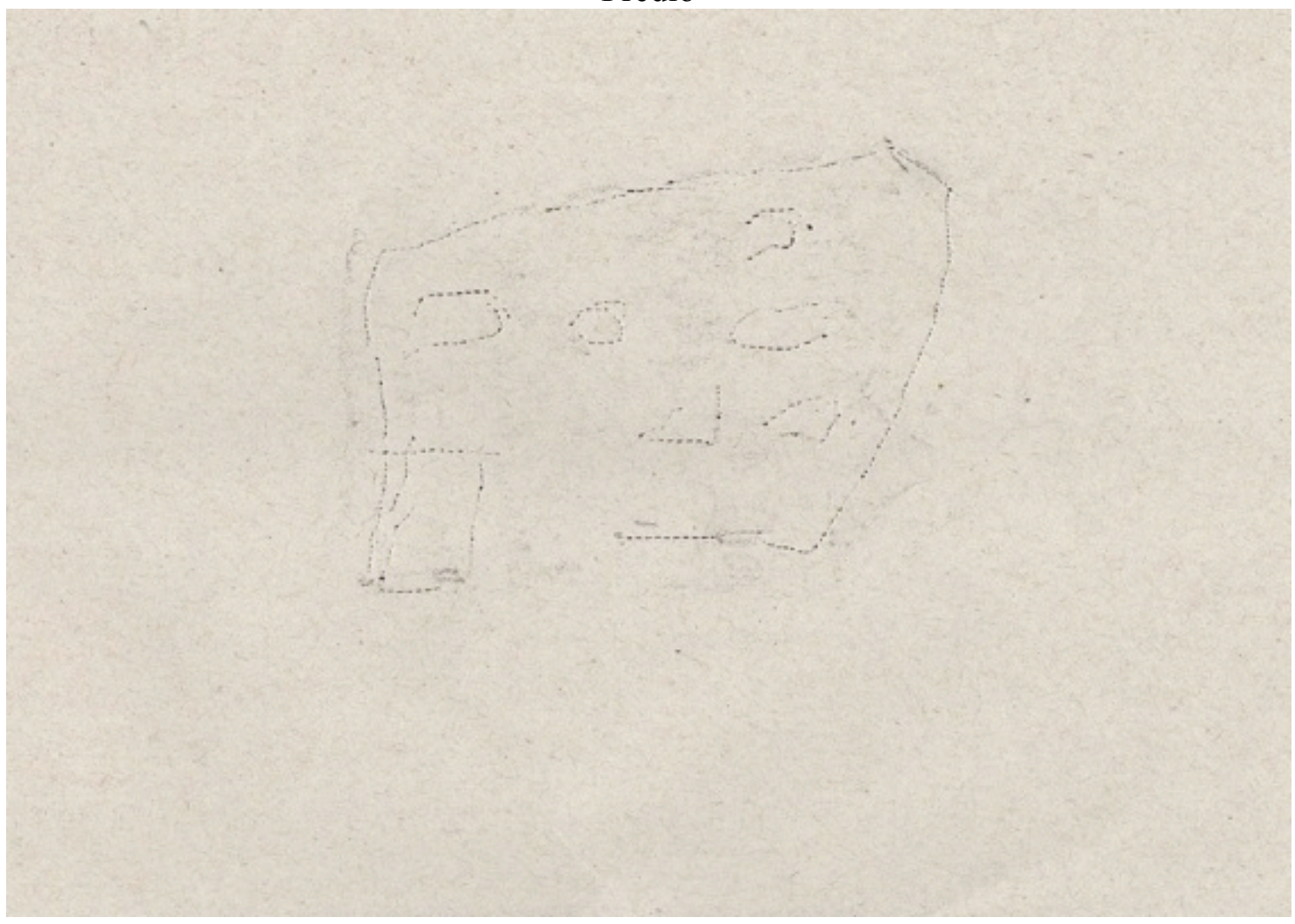

Ilha

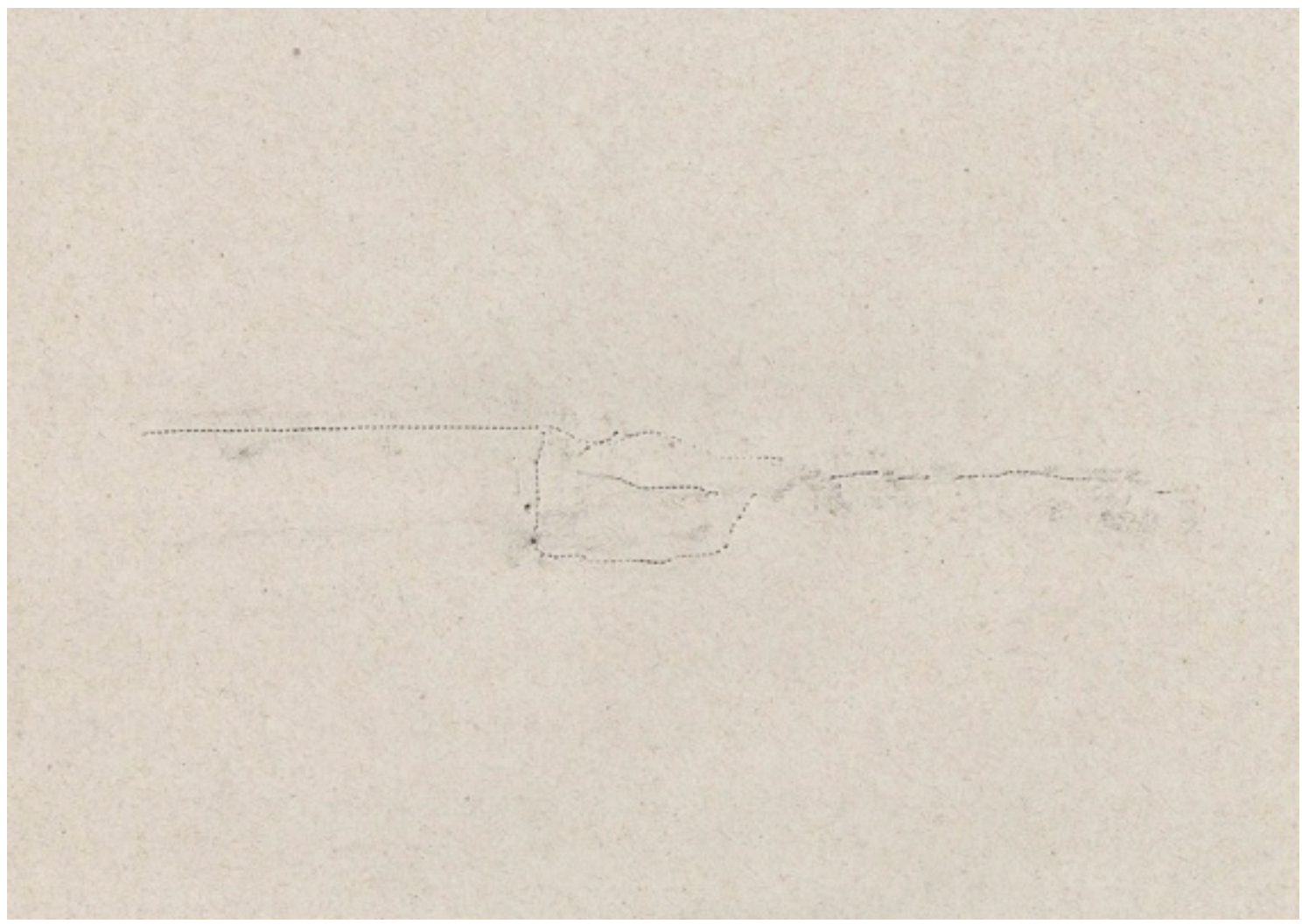




\section{Entrevista Pós-teste: Vítor}

E: Então vamos lá. Hoje eu vou te fazer algumas perguntas, as mesmas perguntas que eu fiz daquela primeira vez, lembra?

$\mathrm{V}$ : Aham.

E: A respeito de algumas coisas, são as mesmas coisas.

$\mathrm{V}:$ Ok.

E: Eu vou te fazer as perguntas, você responde e eu te peço o desenho. Tá bom?

$\mathrm{V}:$ Ok.

E: Vamos lá, começando. Não se preocupe em acertar ou errar, tá certo? Agora eu só quero ver como você responde. Você poderia me dizer o que é uma girafa?

V: Uma girafa é um animal enorme que é da África, né? Eu acho que é da África e tem um pescoço enorme e come folhas das copas das árvores.

E: Tá ótimo. Então você pode repetir pra mim?

$\mathrm{V}$ : A girafa é um animal enorme, tem um pescoção muito, muito, muito grande, come folhas das copas das árvores e eu acho que mora na África.

E: Tá certo. Mais alguma coisa sobre a girafa?

$\mathrm{V}$ : Só isso por enquanto.

E: Você desenha pra mim? Deixa a folha assim mesmo ou você quer que vire a folha?

V: Pode deixar assim.

V começa a desenhar: Vamos lá. Girafa.

E: Isso.

E: Ih, tá virada ao contrário aqui, a caneta.

$\mathrm{V}$ : Opa.

E: Deixa eu arrumar aqui. Pronto, já arrumei. Pode começar.

Vítor desenha.

E: Que parte é essa que você tá fazendo?

$\mathrm{V}$ : O pescoço.

E: O pescoço. Como é que é o pescoço da girafa?

$\mathrm{V}$ : Ele é grande.

E: Grande...

V: Epa, eu coloquei uma parte a mais no pescoço, ficou tipo uma bolha. Uma girafa com bolha.

E: Quer fazer outro?

V: Quero, por favor.

Vítor recomeça o desenho: Ficou tipo uma pinta grande.

E: Ficou o que?

V: Tipo uma pinta enorme.

E: Uma pinta?

$\mathrm{V}$ : É, tipo uma pinta bem grande.

$\mathrm{E}:$ A girafa tem pintas?

V: Tem pintas. (pausa) A girafa tem pintas. Agora a cabeça, as orelhas, atrás, olho, um, dois olhos. Agora é hora do corpo. Pera aí, tem q eu fazer um pontinho no nariz, pro nariz né. Acho que eu vou desenhar uma, um... Eu posso colocar tipo, ah, eu posso colocar um e agora eu rabo.

E: Que parte é essa que você fez?

$\mathrm{V}$ : Eu fiz o corpo aqui.

E: Ah.

V: E agora o rabo. Um rabo comprido.

$\mathrm{E}$ : A girafa tem o rabo comprido? 
V: Preto. Eu faço uma perna. Uma perna, duas pernas, três pernas e quatro pernas. Um mascote.

E: E aí, e essa parte que você tá fazendo, o que é?

V: Tô fazendo as pintas dentro do corpo. As pernas e o rabo eu fiz já. Tem duas, três pintas.

Ah, vou fazer uma pinta aqui é. Uma pinta pra fora. Uma pinta no pescoço.

E: Pronto?

V: Pronto.

E: Beleza.

V: Essa é a minha girafa.

E: Ótimo. Vamos para o próximo?

$\mathrm{V}$ : Vamos.

E: Você poderia dizer o que é nuvem?

$\mathrm{V}$ : Nuvem?

E: Nuvem.

V: Nuvens são gotas d'águas que saem do oceano, viram vapor e vão para o céu. Depois que eles esfriam viram chuvas, algumas vez tem chuva de granizo até.

E: Ótimo.

$\mathrm{V}$ : E as nuvens flutuam.

E: Flutuam aonde?

V: No céu.

E: No céu? Você sabe que forma elas tem?

$\mathrm{V}$ : Onduladas.

E: Vamos fazer então a nuvem?

$\mathrm{V}$ : Vamos fazer uma nuvem.

E: Pode fazer.

V: Vamos fazer uma nuvem do jeito divertido.

E: Como é uma nuvem do jeito divertido?

$\mathrm{V}$ : Uma nuvem enorme, com várias dentro. (ri)

E: Então vai.

Vítor começa a desenhar.

V: Agora eu vou fazer algumas nuvens dentro.

E: Você tá fazendo uma nuvem dentro da outra, é isso?

V: É. Legal né.

E: O que acontece quando uma nuvem fica tão perto da outra assim?

$\mathrm{V}$ : Com o que?

E: No céu.

V: Acho que ela fica... Acho que no máximo que pode acontecer é uma erupção, e cair um monte de água em todo mundo.

E: Erupção?

V: Erupção não. Como é que chama, aquelas negocinhos vão ficar azul e nós vamos ficar sem energia por um tempo.

E: O que que fica azul?

$\mathrm{V}$ : O que?

E: O que que fica azul?

V: Que fica azul?

E: É, que você falou.

V: Ah, fica azul. O céu vai ficar meio, não vai ficar azul na verdade. Vai ficar preto e aí, vai ficar apagado por um tempo. Aí vai cair um terre... Um meteoro.

E: Meteoro? 
V: É, um meteoro. E aí nós vamos ficar sem energia até tirarem o meteoro de onde caiu. Se ele cair em cima de uma usina de força, vamos precisar de um guincho para levantá-lo.

E: Que história hein?

V: Um meteoro é bem pesado, tá?

E: Eu não entendi de onde vai vir o meteoro.

V: Ora, quando uma nuvem explodir, um pouco da água vai pro espaço que vai atrair o meteoro da Terra.

E: Meteoro gosta de água?

V: Água vai empurrar o meteoro pra lá.

E: Tá certo. Bela história. Vamos lá, I. Você poderia me dizer o que é montanha?

V: Montanha? Montanha é um lugar enorme, que também tem alguns animais na montanha.

Tem tipo: o carneiro montês, o puma e também tem o bisão.

E: Nossa, como você conheceu todos esses animais que vivem na montanha?

$\mathrm{V}$ : Ah, eu vi na tevê.

E: Na televisão?

V: É.

E: Então tá bom. Mais alguma coisa? Sabe como é que é o formato dessa montanha?

V: Montanha tem ponta.

E: Pode fazer montanha então.

V: Posso colocar um animal nele?

E: Pode.

V: Agora que animalzinho eu posso fazer numa montanha?

E: Como que é essa montanha? Ela é muito alta.

V: É sim.

E: Pronto?

$\mathrm{V}$ : A montanha tá pronta.

$\mathrm{E}: \mathrm{O}$ que você fez aqui?

$\mathrm{V}$ : Ah, tava tentando fazer a ponta aí coloquei um pouquinho a mais.

E: O animal você não fez?

V: Acho que eu vou fazer um carneiro, um bisão. Uma perna de bisão. Queria saber quantas pernas tem um bisão.

E: O que que é um bisão?

V: Um bisão é um parente do... É um parente do... Eu acho que é parente da cigarra, né? Mas minha mãe disse que não.

E: Então é um inseto, parente da cigarra?

V: Não. O bisão é enorme. Eu acho que é parente da cigarra. Eles fazem o mesmo som.

E: Como é que é o som?

$\mathrm{V}:$ ZZZZZZZZZZZZZ!

E: Esse é o som que o bisão faz?

$\mathrm{V}$ : É, mas ele faz sem parar.

E: Ah...

V: Eu vou fazer ele com três pernas, não eu vou fazer com quatro que é melhor. Tá aqui as pernas. Um bisão não tem pintas. O bisão é um animal que é feroz e fica perto das montanhas. E algumas vezes tem na montanha. Isso aqui tá parecendo um puma, o puma tem uma pinta no meio. Eu fiz uma pinta no meio. Então vou fazer um puma vai. Vamo lá. Vou fazer uma cabeça assim, o corpo, e aí pega o olho e o outro olho! E meu puma está pronto.

E: Pronto?

V: Pronto. Olha o meu puma.

E: Tá grande ele hein?

V: É um puma. É um puma escalando uma montanha, quase no topo. 
E: Ótimo, valeu. Vamos para o próximo.

V: Tá legal.

E: Você poderia me dizer o que é uma árvore?

V: Árvore? Bom, uma árvore é uma coisa que fica na terra, que também é de madeira... De madeira? É, de madeira, vai. É de madeira e cupins adoram comer árvores. Elas tem copas e podem ser bastante altas.

E: Uhum, que mais?

$\mathrm{V}$ : As árvores também podem ser comidas por algumas girafas e cupins e castores. As árvores...

E: As girafas comem a mesma coisa que o cupim?

$\mathrm{V}$ : Não, as girafas comem as copas.

E: Hum, e o cupim?

$\mathrm{V}$ : O cupim come a árvore, sem as folhas.

E: Tá.

V: Só as que caem. E os castores comem... Os castores usam a árvore para fazer a casa deles, a represa debaixo da água.

E: Muito bom, você desenha pra mim uma árvore então? Deixa eu ajeitar a folha aqui.

V: Você quer que eu faça uma árvore sendo derrubada por um castor?

E: Do jeito que você quiser. Eu quero que você desenhe uma árvore, tá bom?

V: Tá legal.

Vítor começa a desenhar: Vamos ver aqui, o que que eu posso fazer. Tá legal, eu vou fazer uma árvore, uma árvore, uma árvore. Esse aqui é a presa enfiada do castor.

E: Essa parte que você tá desenhando aí qual é?

V: É a copa. Agira eu vou desenhar... Que que eu posso desenhar pra roer? O castor tem duas presas, então vou aumentar o tronco, aí aqui em cima tem duas presas, enfiadas na árvore.

E: Que presas? De onde vem essas presas?

V: Do castor. Que enfiou elas aí pra derrubar a árvore.

E: Entendi.

V: Então vamos fazer um castor aqui. Esse aqui é o resto da boca do castor. PÉ uma cabeça enorme porque o castor é enorme. Agora os olhoV: um olho, outro olho. Agora eu vou fazer o corpo. Um castor tem duas pernas, ou será que tem quatro? Eu vou fazer um com quatro, ou com duas? Vou fazer com quatro. Uma, duas, três, quatro. O castor ficou meio errado. Ele tá com uma perna, ele tá com uma perna nas costas.

E: Ixi.

V: Olha só.

E: Deixa eu ver. Oh, tá legal, tá ótimo. Muito bom, vamos para o próximo. Você pode me dizer o que seria um trem?

V: Trem. Um trem é um veículo super rápido. Tem coisas gigantes que se chamam vagões.

Tem o vagão restaurante, tem o vagão dos passageiros, tem o carro breque, tem a locomotiva.

E: Quanta coisa hein?

$\mathrm{V}$ : E o trem também tem várias rodas, e uma coisa: só anda num buraco.

E: Num buraco?

V: É.

E: Como é que é isso?

V: Debaixo da terra. Não, debaixo da terra é o metrô. O trem é em cima da terra.

E: Hum, entendi. Então ele anda em cima da terra?

V: Ele anda num buraco na terra. É que o metrô anda no subterrâneo né? Aí tem diferença.

E: Entendi. O metrô é um trem?

$\mathrm{V}$ : O metrô é como se fosse um trem.

E: Tá. Então você desenha um trem pra mim? 
V: Tá legal.

E: Dá pra desenhar na folha assim ou você quer que vire?

V: Hum... pode virar (e tirou a folha)

E: Não, a gente vira a prancha.

$\mathrm{V}:$ Ah! tá, entendi, vira a prancha.

E: pode prender primeiro.

V: Vira a prancha.

E: Deixa eu te ajudar aqui. Vai lá. Desenha um trem aí.

$\mathrm{V}$ : Um trem, né? Um trem.

E: Isso.

$\mathrm{V}$ : Esse vai ser um trem super grande.

V Inicia o desenho: Vai ter que pegar essa parte aqui em baixo, vai pra cima aqui e aí fazer uma locomotiva. Tá aqui. Aí a fumaça saindo de dentro. É uma fumaça enorme. Agora eu vou fazer os vagões primeiro.

E: Quantos vagões você vai fazer?

V: Dependendo do tamanho do lugar eu acho que eu posso fazer... Eu num sei quantos que eu posso fazer. Mas vamos tentar. Um vagão, dois vagões, três vagões, quatro vagões. Quatro vagões. Cinco vagões. Cinco vagões, agora o sexto vagão. Sexto vagão. Agora as rodas.

E: Quantos vagões você fez?

V: Deixa eu ver: Um, dois, três, quatro, cinco, seis, sete, oito.

E: Oito vagões?

V: Esse aqui é a locomotiva, mas esse daqui tudo é vagão. Sete. Sete vagões. Agora eu tô fazendo as rodas. Uma, duas, três, quatro, cinco, seis, sete, e a oitava, bem grande no fim. Ele é assim, é.

E: Uhum, muito bom. Vamos pro próximo. Você poderia me dizer o que é leão?

V: Leão é um animal que vive na África do Sul. Devorador de humanos, alguns guepardos e insetos. É o rei da selva e pode comer vários animais que comem planta. Não. O leão come os animais que comem a planta.

E: E como é o leão?

$\mathrm{V}$ : Tem um rabo, tem uma juba e tem que saber se é leoa ou leão

E: E qual a diferença?

V: O leão tem juba e a leoa não tem.

E: Ah tá. Você sabe qual o tamanho do leão.

$\mathrm{V}$ : Mas ou menos uns quatro metros de altura.

E: Quatro metros de altura?

V: Eu acho que sim, né! Pelo tamanho do leão.

E: E isso é muito grande?

V: Hum, é maior do que meu pai.

E: E seu pai é grande?

$\mathrm{V}$ : Meu pai é 1e 80, acho.

E: E o leão é mais alto que seu pai?

$\mathrm{V}$ : Bem mais alto!

E: O leão é grande mesmo. Então vamos desenhar o leão. Você vai fazer um leão ou uma leoa?

V: Não sei.

E: Faz os dois então.

V: Vou fazer filhote que é menor. Hoje na escola a gente viu uma reportagem de animal, né, era sobre hipopótamo. Hoje o hipopótamo tem 16 anos.

E: Hum. Pode começar.

V: Acho que eu fiz o leão muito grande. Vamos lá, vou fazer os olhos dessa leoa. 
E: Que barulho é esse?

$\mathrm{V}$ : Sou eu imitando um leão.

$\mathrm{E}$ : Ah, como é que ele faz?

$\mathrm{V}$ : Uhuuuu. ( continuou fazendo o barulho enquanto desenhava).

V: Epa, eu acho que eu fiz um camelo.

E: Fez o cabelo? Por quê?

V: Porque olha aqui, tem uma corcova. É um dromedário. Foi mal.

E: Mas dá pra fazer o leão ainda?

$\mathrm{V}$ : Eu fiz uma leoa, isso ai já conta né?

E: Conta.

V: Porque faz parte da família do leão.

E: Tá bom. Explica as partes dele pra mim.

V: Olha só, esse aqui é o camelo: tem uma corcova, uma... opa, esqueci dos olhos do camelo.

E: É um camelo ou é uma leoa?

V: É um camelo, a leoa tá embaixo.

V: Tem o camelo, tem a corcova e aqui tem a fuça. Aqui é a leoa.

E: Peraí, deixa eu ver.

S mostra o desenho.

E: Ah tá! Agora entendi.

$\mathrm{V}$ : Sem a juba.

E: Posso pegar?

V: Pode. Eu torço pro São Paulo, a Jozi também.

E: Ah é?! Podemos continuar?

$\mathrm{V}$ : Pode.

E: Você pode me dizer o que é um prédio?

$\mathrm{V}$ : Um prédio é um monte de casa, uma em cima da outra. $\mathrm{E}$ as vezes tem elevador. $\mathrm{O}$ elevador pode ser, não um prédio pode ser de 20 andares, de 5 andares de 2 andares.

E: De vários andares?

$\mathrm{V}$ : Éeeeeee, sim.

E: Então tá bom, você pode desenhar pra mim?

$\mathrm{V}$ : Tá bom?

E: Por onde você vai começar.

V: Eu vou começar pela portaria. Faz isso. Amanhã eu não tenho aula, é o TRE, pra poder votar lá na minha escola todo mundo que mora ali na região. Como eu moro lá, eu voto na minha região.

E: Você já tá votando?

V: Eu não, mas eu voto com meu pai. Ele vai lá e eu aperto o botão pra ele.

E: Como é que tá ai? O que você tá fazendo agora?

V: Os apartamentos. Tá, um andar tem uma, duas, três, quatro, cinco apartamentos.

E: Você já sabe quantos andares quer fazer.

V: Um prédio de 500 metros quadrados.

E: Tá pode continuar.

V: Sabe que o bife a parmegiana tem bife a milanesa, queijo e molho.

V: Opa, eu fiz um apartamento um dentro do outro, eu acho.

E: Cadê?

V: Aqui ó. Ficou muito grudado.

E: Não em problema não.

E: Pronto?

V: Prontinho.

E: Ficou ótimo. Você pode me dizer o que é ilha? 
V: Ilha é um lugar cercado de água cheio de areia. E tem siris lá.

E: Tem siris lá?

V: Tem, na ilha comprida tem.

E: É mesmo, você já foi lá?

V: Já, meu avô tem uma casa virada pra praia.

$\mathrm{E}$ : Ah, até eu quero essa hein! Você pode desenhar ilha pra mim?

V: Tá. Iiiiilhaaaaa.

E: Deixa eu ver. Como é que você fez aqui, me explica.

$\mathrm{V}$ : Esses aqui são a água e aqui a parte de terra.

E: Muito bem, muito obrigado. Te agradeço por toda a sua ajuda. 


\section{Desenhos pós-teste: Vítor}

Girafa

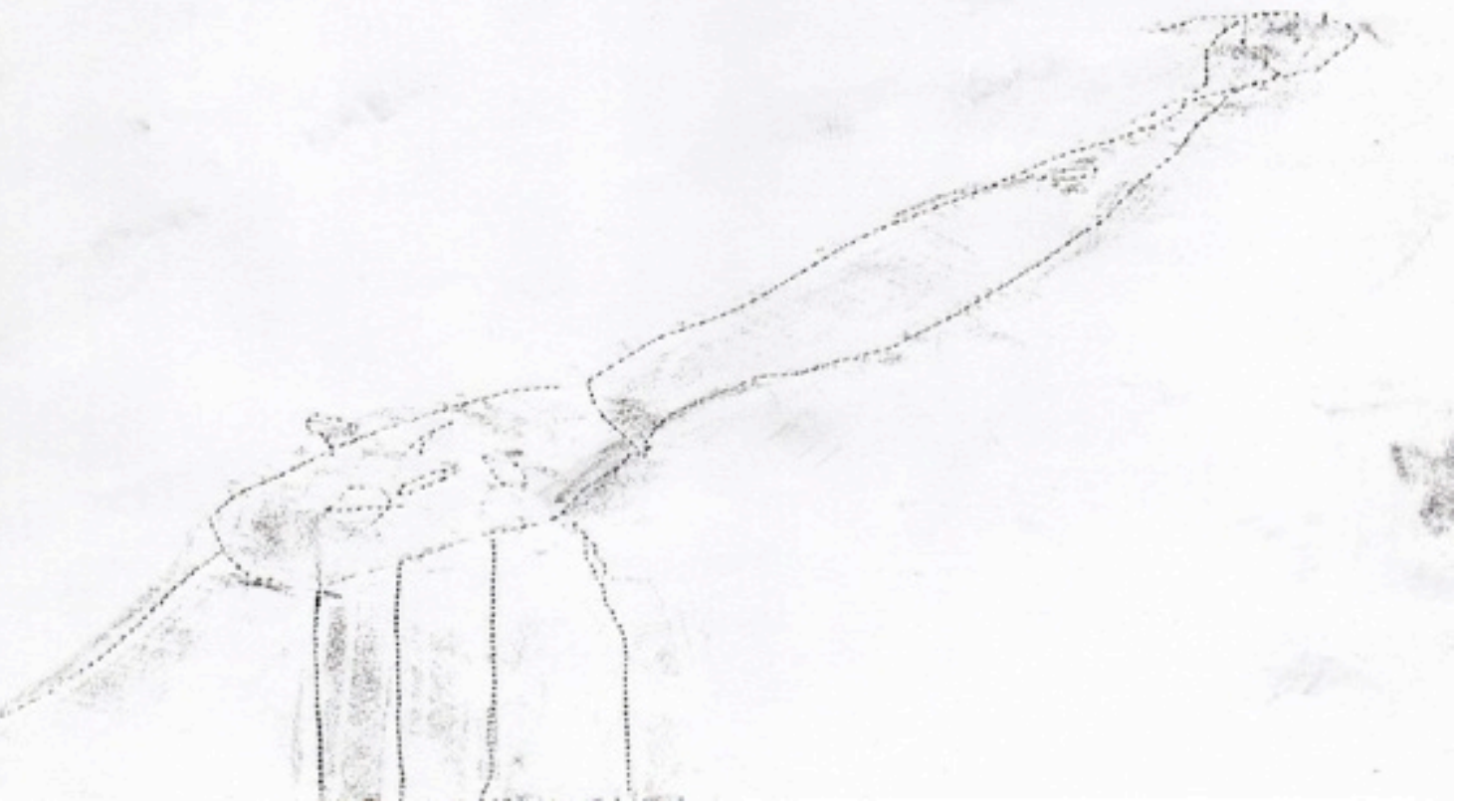

Nuvem

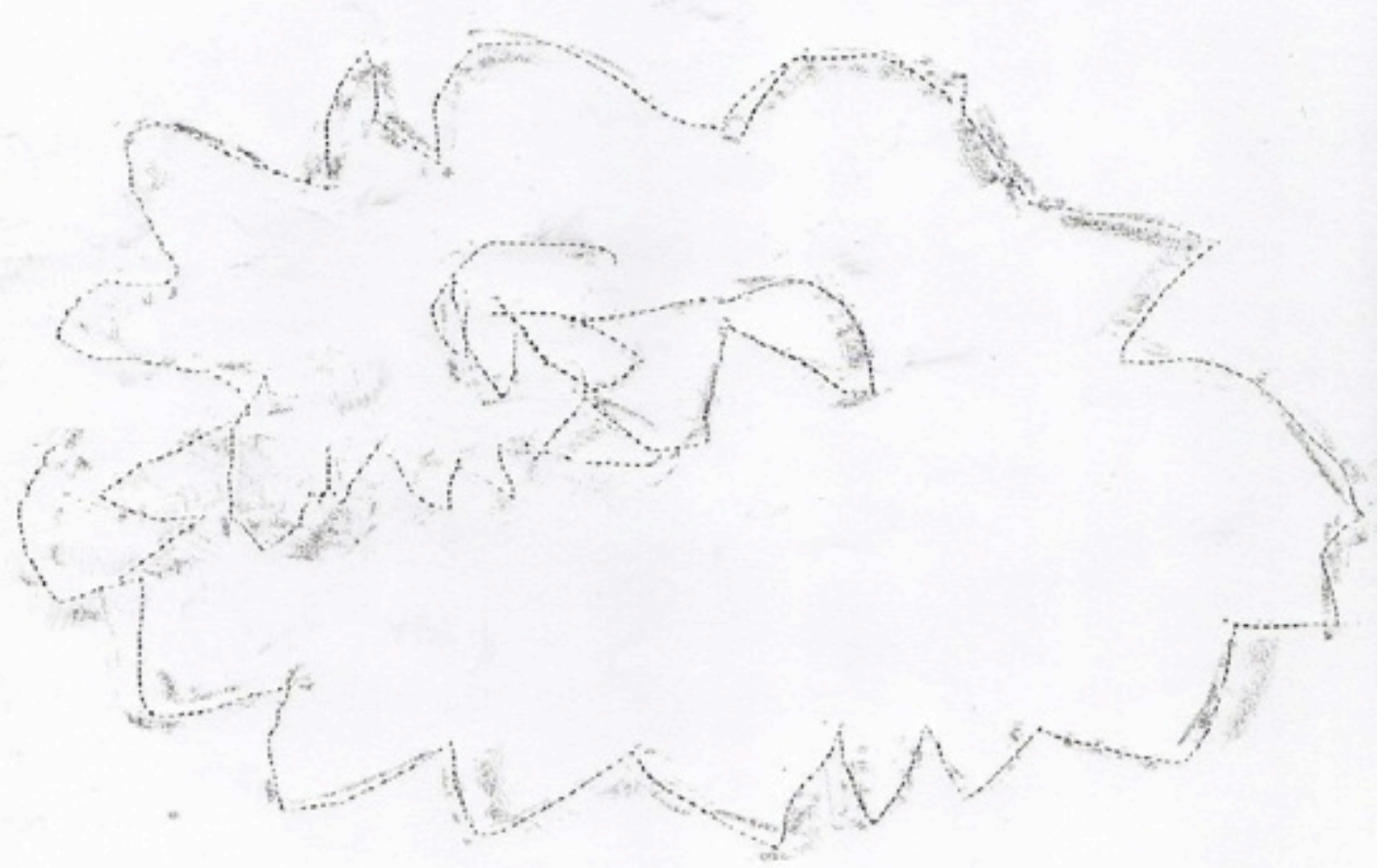




\section{Montanha}

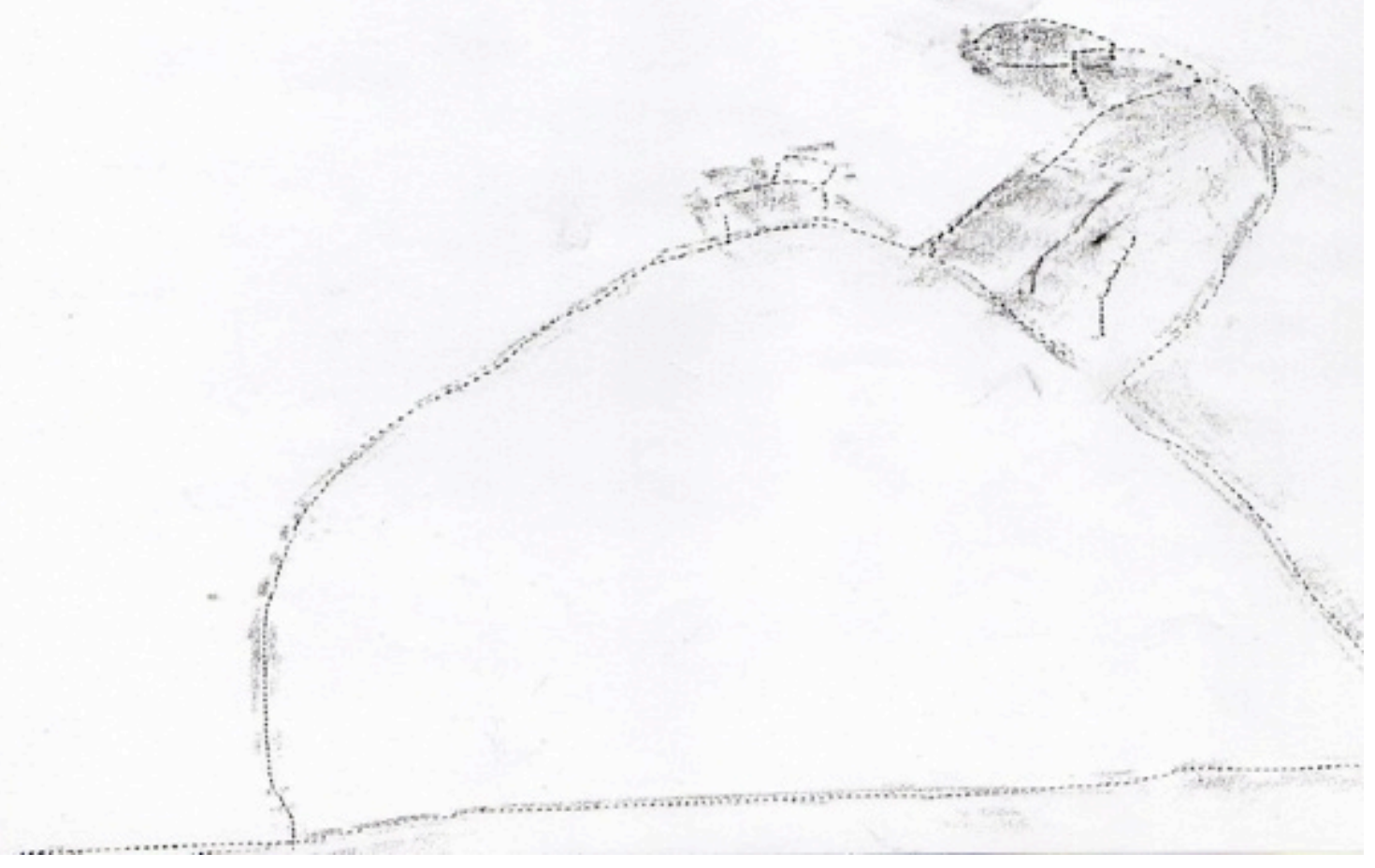

Árvore

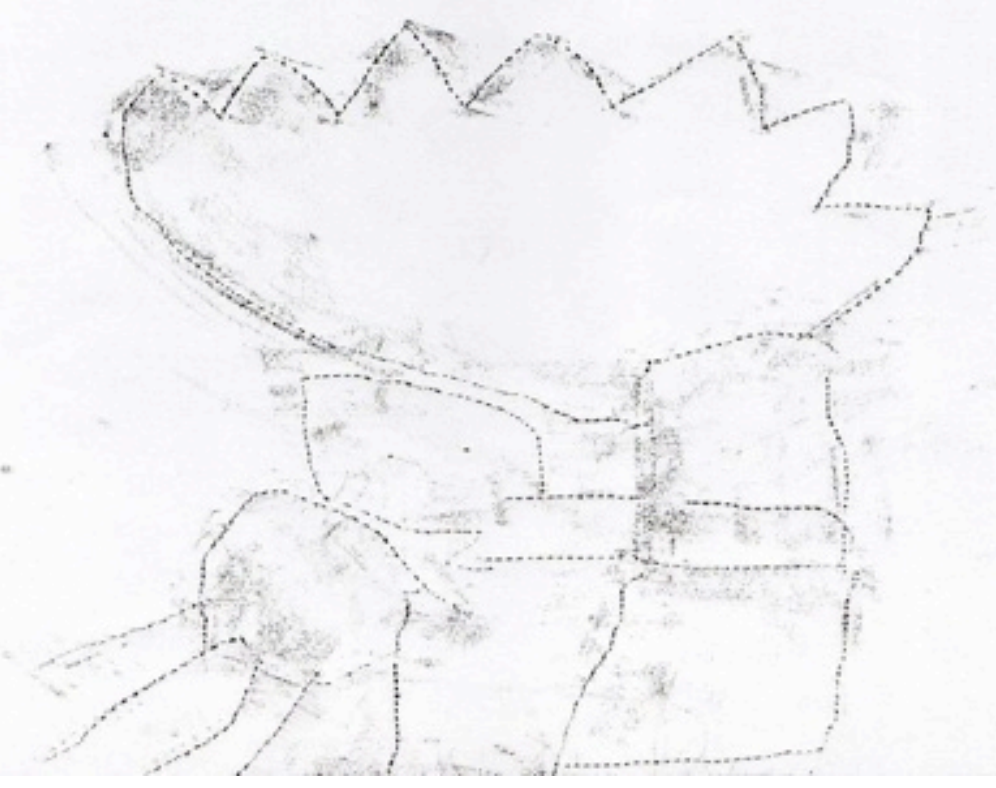




\section{Trem}

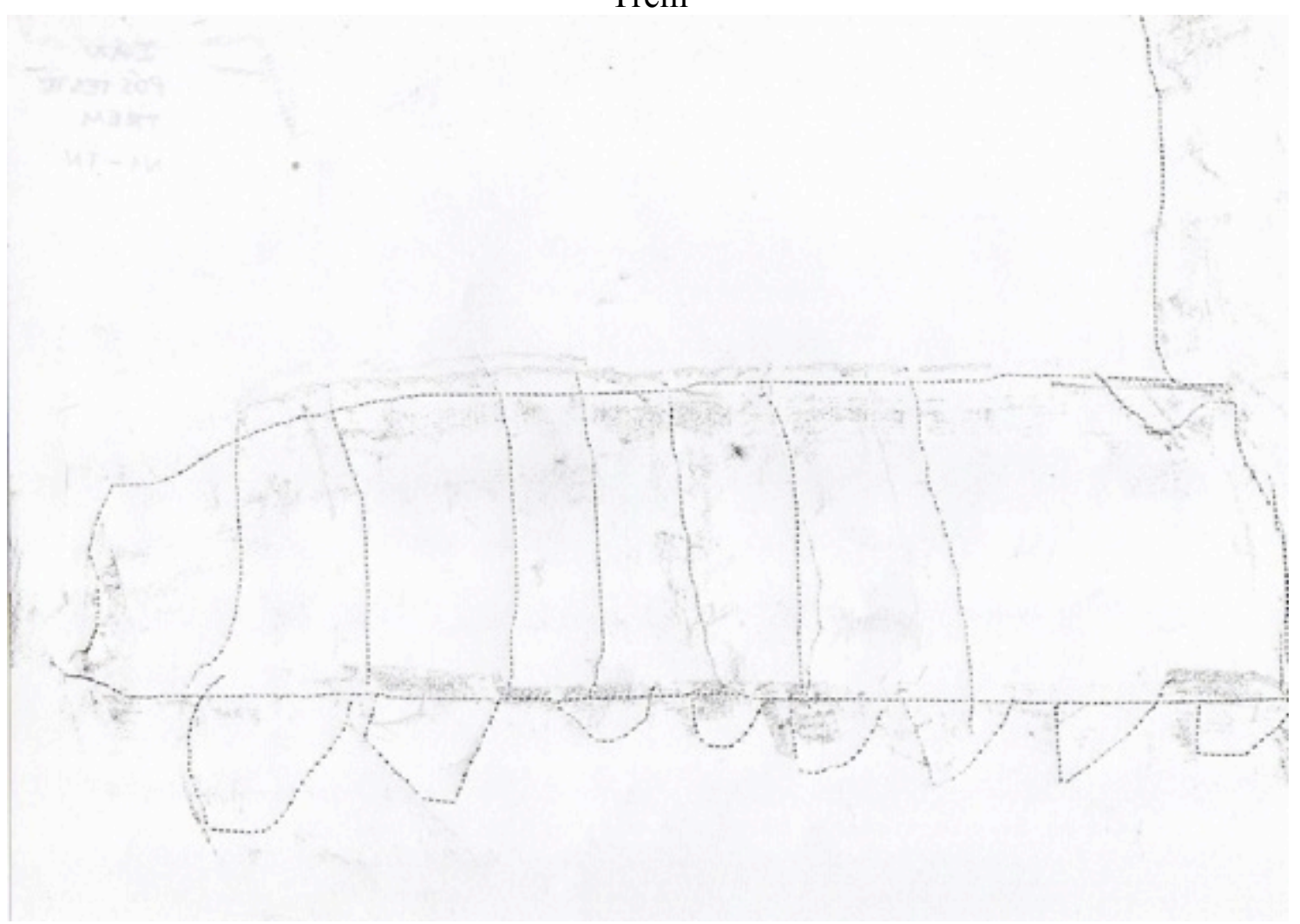

Leão
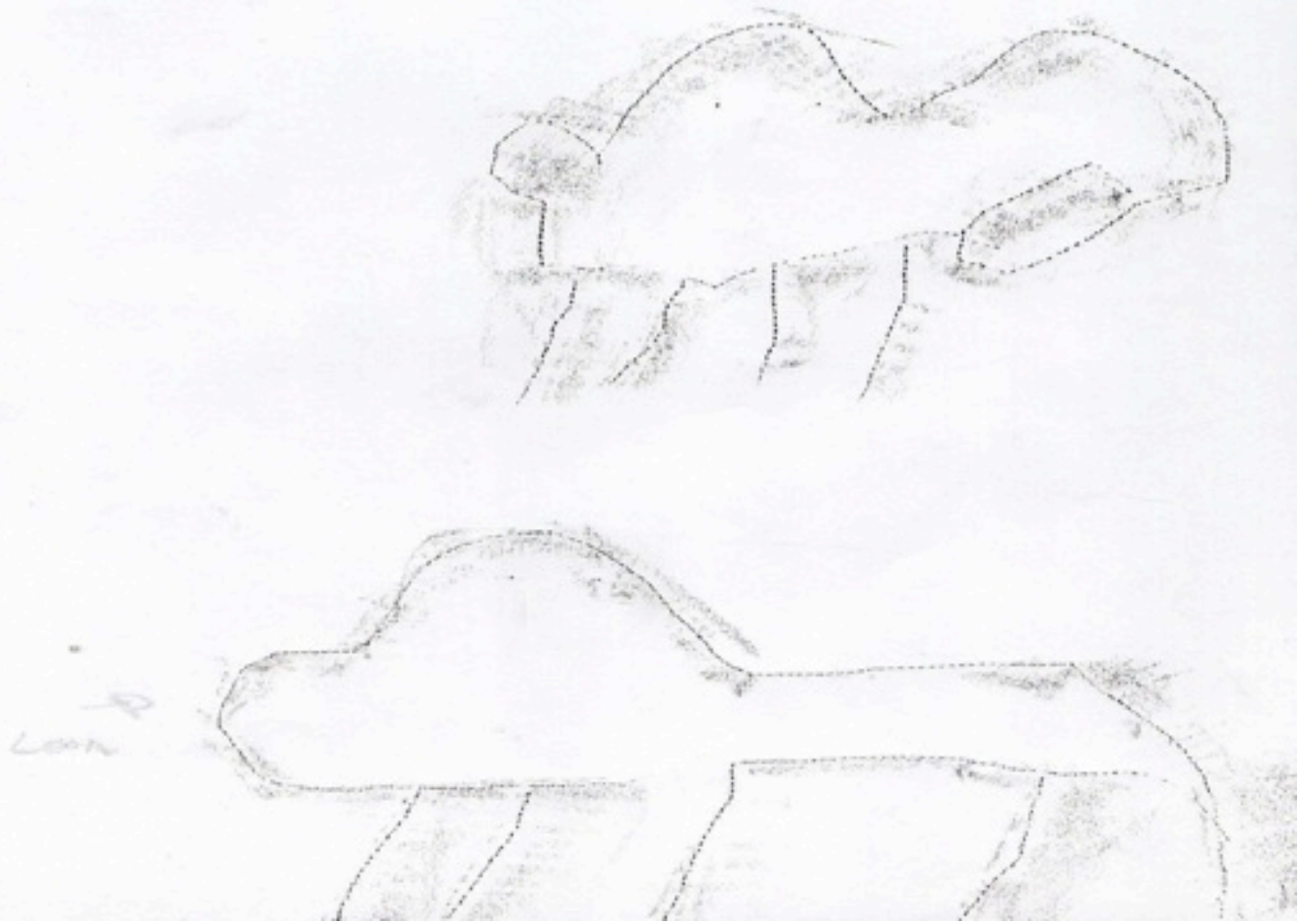
Prédio

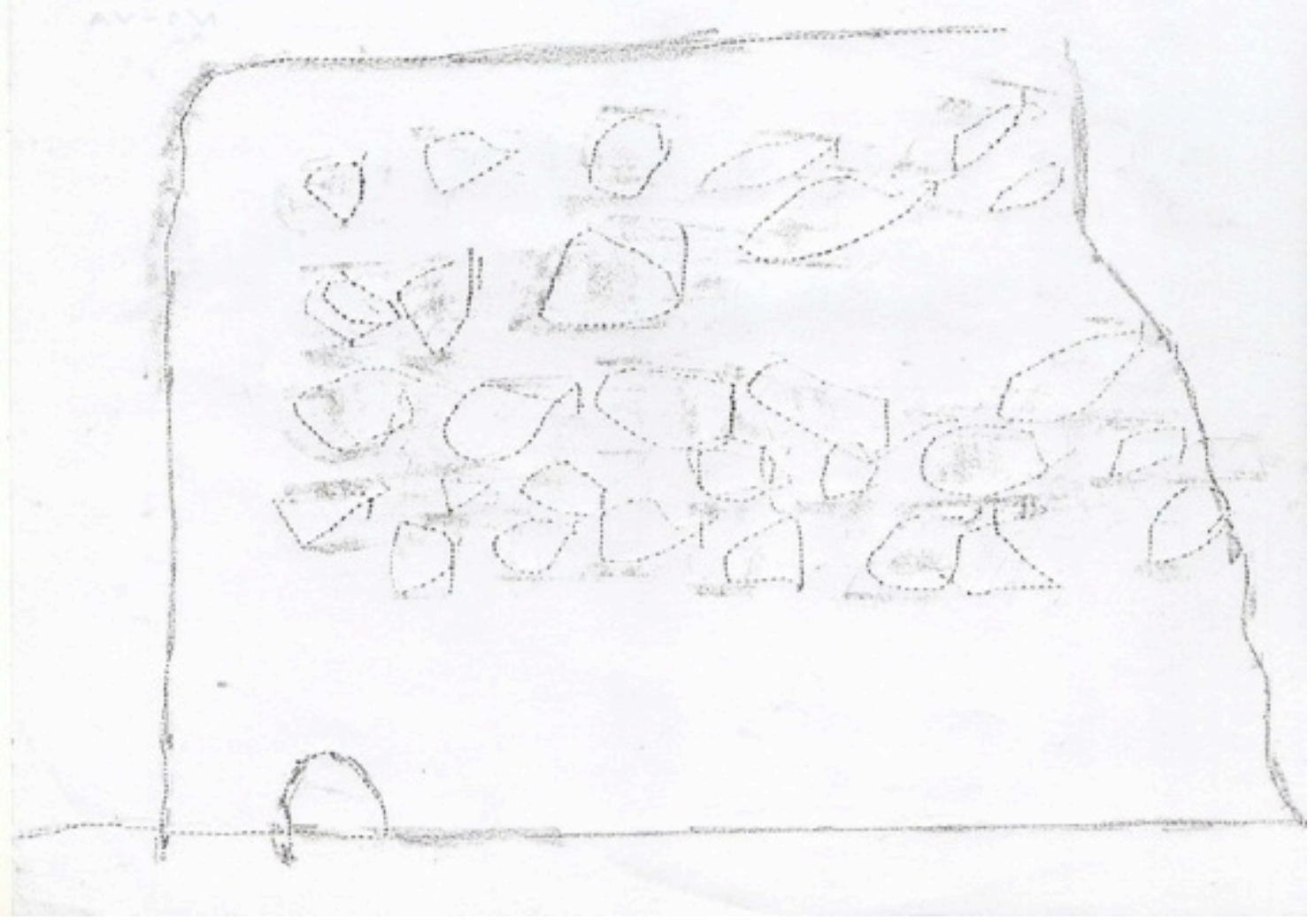

Ilha

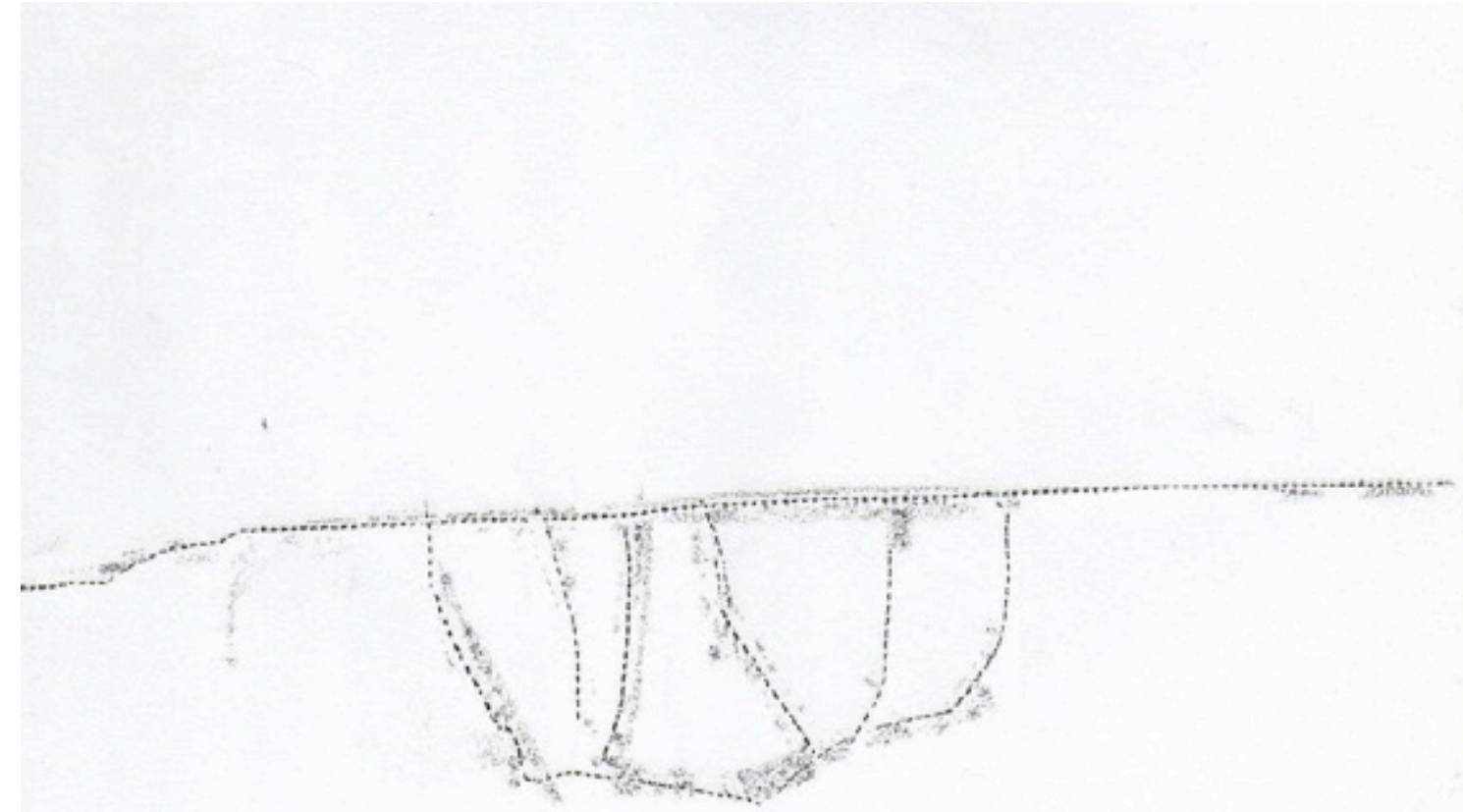




\section{Entrevista Pré-teste: Bruno}

E: Bom, B., então eu vou te fazer uma pergunta sobre algumas coisas, tá bom? E você me responde sem se preocupar se você tá acertando ou errando, o objetivo é saber qual é sua ideia a respeito das coisas que eu vou perguntar, tá bom?

B: Tá bom.

E: Bom, primeiro: você poderia me dizer o que é uma girafa?

B: É... Eu assim, eu acho que a girafa ela, ela é bem grande, bem alta, com pescoção assim, ó, pescoção, grandão.

E: Que tipo de coisa é a girafa?

B: Oi?

E: Que tipo de coisa é a girafa?

B: Ah ela é um animal assim, como vou dizer, ela é bem, bem feroz, bem brava. Eu acho que ela é brava.

E: Você acha que ela é brava?

B: Eu acho.

E: Você já viu uma girafa alguma vez?

B: Não, não, não.

E: Onde que a girafa vive?

B: Na floresta.

E: Floresta. Nunca fui numa floresta.

B: Eu já.

E: Já mesmo? E não tinha girafa lá?

B: Tinha.

E: É mesmo? E você não ficou com medo?

B: Não, não. (ri)

E: Então tá legal. Vamos pra próxima. Você pode me dizer o que seria nuvem?

B: Bom, a nuvem, pelo que eu acho que a nuvem é, é... É um tipo de um... É... Como eu posso descrever aqui, um algodão, vai, um algodão. Que dão quando na água dos rios, fica em, quando enche ela, quando fica... As água do rio fica com térmica, acho que é térmica, não sei como é que é, que ai quando a água do rio fica devolvida aquela... Aquela água sobe... É... É... Ah! Vapora, isso vapora. Aí cota pras nuvem onde que elas fica cheia e onde que chove. Aí cai toda água dela.

$\mathrm{E}: \mathrm{E}$ onde que fica a nuvem?

B: No céu. (ri)

E: No céu.

B: No céu.

E: Como é que você sabe tudo isso?

B: Ah, porque eu perguntei pra minha mãe: Mãe onde que fica a nuvem? Aí ela falou: No céu. Era pequeno, não sabia o que era uma nuvem, não sabia o que era nada. Perguntei pra ela, ela falou pra mim o que que é uma nuvem, aí eu falei "a nuvem é... E do lado... E ela é bem... Mó grandona".

E: Tá ótimo. Vamos para o próximo. Você poderia me dizer o que é montanha?

B: Montanha.

E: É.

B: (suspira) Ó, montanha eu acho que tem a de gelo e tem a de barro. A de gelo é bem alta, bem altona, bem alta (gesticula com os braços), ela é muito alta essa montanha. E tem um monte de gelo onde, onde, ah onde que... Onde vivem os animais, tipo, os animais do gelo, é... urso, é... pinguim.

E: Ela é toda de gelo essa montanha? 
B: É, toda de gelo. Depende, tem a de gelo e tem a de barro

E: E como que é a de barro?

B: Ah a de barro ela... Depende. Tem a montainha montainha e a montanhona, depende do monteiro, se ela for grande né, ela é bem alta, se for pequena é pequena. Aí...

E: E ela é feita de barro, é isso?

B: É, feita de barro.

E: Então tá legal. Você conhece alguma montanha?

B: Não, não.

E: Tá legal. E como é que você sabe tantas coisas sobre elas?

B: Ah escuto pelo jornal ué. (ri)

E: Ah, legal. Vamos pro próximo?

B: Opa.

E: Você poderia me dizer o que é árvore?

B: Ah, árvore é um pé, é um pé. Que é onde tipo... Tem pé de laranja, tem pé de laranja, pé de maçã, pé de mexerica, enfim, são vários... é um monte de pé, assim, um monte de árvore onde tem os galho, os passarinho, as fruta onde elas nascem.

E: E como é uma árvore?

B: É um pé, de pé assim (gesticula com os braços), aí tem uns negócios que você segura aqui (gesticula) e vai subindo, vai escalando, aí você chega lá no topo e pega lá a fruta que você quiser, pega, vamos supor que é um pé de laranja, pega laranja...

E: Você já subiu numa árvore?

B: Já, num pé de pitanga.

E: Num pé de pitanga?

B: Mas não subi muito alto não, só fui até o meio só, não consegui subir.

E: E como é que ela era, essa árvore?

B: Ah era do mesmo jeito. Ela é assim (gesticula), ela é assim você sobe e vai subindo. Aí você vai subindo (gesticula) pros galhos lá em cima, lá no alto, bem no alto. Mas não é tão alto assim, exagerei. (ri)

E: (ri) Então tá bom. Você poderia me dizer o que é trem?

B: Trem eu já peguei todo dia, eu sei o que é. Trem é um outro tipo de transporte que ele anda no trilho. Ele é bem rápido, depende, tem uns maquinistas que é lerdo, mas tem alguns que é bem rápido. E tem um monte de vagão, um vagão aqui, outro aqui, igual montanha russa, sabe, tem umas montanha russa que os carrinhos dela é tudo aqui assim, andam no trilho? (gesticula). É assim, tem um vagão aqui, outro aqui, outro ali, outro aqui, outro ali, outro aqui, e assim vai (gesticula). Depende do trem, se for pequeno, é pequenininho, se for grandão, aí tipo... E ele tem um cheiro viu, um cheiro ruim.

E: É mesmo? Cheiro do que?

B: Ah sei lá. Cheiro de fumaça. Acho que é por causa dos trilhos na hora que ele... na hora que ele pára, queima o pneu, queima a roda de ferro (bate as mãos). E aí fica lá aquele cheiro.

(ri) Fica aquele cheiro ruim. Credo.

E: Então tá legal. Muito bom. Vamos pro próximo. Você poderia me dizer o que é leão?

B: Eita esse aí... É um leão... o leão é bravo.

E: É mesmo?

B: Bom leão... Ele é um... Pelo que eu sei que falaram de leão ele tem... Ele tem uma juba. Uma juba. (ri)

E: O que é uma juba?

B: Um cabelão, um monte de cabelo, sabe aqueles cabelão que nunca corta? Um monte de cabelão, e ele fica (imita o som do animal). E ele come carne, eles são carnívoro.

E: E onde que vive o leão?

B: Também na floresta. 
E: Também na floresta?

B: Depende, tem leão marinho, tem...

E: Boa, boa. Tem vários tipos de leão então?

B: Tem, tem. Tem o leão aquático, tem o leão da floresta. Tem um monte... E eles são bem bravo.

E: É mesmo? Como é que você sabe que eles são tão bravos assim?

B: Ah, eu escuto no jornal, né. Por causa... Inclusive eu vi uma reportagem que um cara tava na floresta brincando, tava treinando o leão dele lá. O leão assim (imita o som do animal), pegou a... a garra dele, fez assim no cara (gesticula), o cara... O leão quase engoliu o cara, o cara ficou assim, é... prensado assim na... Como é que é? Na... Na presa do leão, e ele assim (gesticula). Não é assim que é pra fazer não, ele é bem bravo, vai? Mexer com o leão não. (ri)

E: Está ótimo.

B: Tem a leoa também que o marido, a mulher dele...

E: E ela é igual a ele?

B: Ahan. Bem brava.

E: Ela é brava, tem essa jubona?

B: Tem a jubona. Depende. Tem a jubona, tem a que não tem. Vixi, tem um monte.

E: Tá ótimo. Vamos lá. Você poderia me dizer o que é prédio?

B: Bom, prédio eu sei. É um monte de... É... Prédio é um... É... Uma torre com um monte de casa, apartamento, grande, por onde você sobe pelo elevador. É um monte de casa, tem condomínio, tem piscina, tem área de lazer dentro.(ri)

E: Ah é? Você mora em prédio?

B: Não, casa.

E: Mora em casa. E você já foi num prédio?

B: Já, já. Meu pai é mestre de obra, né, então ele trabalha, ele faz prédio.

E: Hum.

B: É, aí eu já fui num lá e fiquei brincando com o elevador, subindo e descendo. Mó da hora.

E: Seu pai já te levou na obra?

B: Já, já. Lá tem piscina, é mó da hora. Da hora. Prédio. Ele é bem alto, depende, tem prédio pequeno e prédio alto, aqueles grandão.

E: Ótimo.

B: Também tem o prédio da... Prédio da... Tem prédio de rádio.

E: Entendi. Beleza. Vamos para o último?

B: Opa!

E: Você pode me dizer o que é ilha?

B: Bom ilha não vou conseguir descrever, mas eu acho que uma ilha é... Diz... Me falaram que uma ilha é... É... (pausa) mar e terra. Falaram que ela é grande, e tem os animais, tem galo, tem galinha, tem cachorro, tem pássaro, tem... É... Deixa eu ver assim como eu posso descrever. Ah depende, tem ilha grande com vários animais grandes também. Tipo é... Assim, mas eu acho que é isso mesmo uma ilha, eu imagino pela minha imaginação.

$\mathrm{E}$ : E quem descreveu pra você? Você falou que te contaram, quem descreveu pra você?

B: Meus colegas da $2^{\text {a }}$ série, eu falei pra eles "o que é uma ilha?" e eles me falaram pra mim o que é.

E: Legal. Muito bom. Beleza. Agora vou te mostrar alguns desenhos.

B: Opa.

E: E você vai tentar... Esses desenhos representam essas coisas que eu te perguntei, tá?

B: Ok.

E: Algumas delas. Eu queria que tocando você tentasse descobrir o que é, tá bom?

B: Ok.

E: Se você não conseguir descobrir eu te falo. 
E: Dá pra sentir?

B: Tô sentindo um qua... É, tipo um quadrado.

E: Das coisas que nós conversamos o que poderia ser?

B: Eu acho que é uma ilha.

E: Uma ilha? Toca um pouco mais.

B: Tem um monte de quadradinho, tem aqui, tem aqui, tem aqui, dentro um do outro, quer dizer, tem um monte de quadradinho dentro de um grandão.

E: E o que que poderia ser isso? Você acha que é uma ilha?

B: Bom, eu acho, eu acho que é.

E: Por quê?

B: É porque ela é do mesmo jeito, que tem terra aqui, parece que a terra é aqui, e o mar é dentro dela. Dela aqui ó, o mar.

E: Hum... Posso te contar o que é?

B: Pode.

E: Isso aí é um prédio.

B: Ai.

E: Tá vendo esse quadradão?

B: Tô.

E: Então, esse quadradão é...

B: É os apartamentos aqui né?

E: Isso, são as janelinhas. Esses quadradinho são as janelas. E ai embaixo tem um retângulo de pé...

B: Tem.

E: Que parece um... Qu seria a porta aqui.

B: Esse quadradão né?

E: É, esse quadradão é o contorno do prédio.

B: Ok.

E: Certo?

B: Ok.

E: Você não falou.... Lembra que você falou que era uma torre. É que ta um pouco mais baixo pra ser uma torre. Mas esse aqui ó, posso pegar sua mão?

B: Pode.

E: Isso aqui seria a porta. Aqui uma janela mais comprida.

B: Gostei dessa janela aí hein?

E: Gostou?

Bruno ri.

E: E aqui pra cima são os apartamentos. Quantos andares tem esse prédio?

B: Deixa eu ver, um, dois, três. Um, dois, três... Deixa eu ver as janelas, um, dois, três, quatro, cinco, seis. Seis andares?

E: Tem seis janelas. Como é que contam os andares?

B: Primeiro, segundo, terceiro, quarto, quinto, e sexto. É, seis andares mesmo.

E: Beleza. Posso te mostrar outro?

B: Opa.

E: Vamos ver.

B: Gostei desse prédio hein, prédio bonito.

E: Gostou?

Bruno ri.

E: Depois a gente vai aprender a desenhar ele. E esse ai?

B: Quem sabe eu vou desenhar um parque de diversões?

E: Pois é. 
B: Ai, esse aqui. Deixa eu ver aqui, é um leão.

E: Um leão?

B: É, acho é um leão.

E: Me mostra as partes desse leão.

B: Aqui é a boca dele.

E: Aham.

B: Aqui é a perna, eu acho.

E: Quantas pernas ele tem?

B: Duas.

E: Cadê?

B: Essa daqui e aqui ó. Essa e essa aqui ó. Aqui é a boca dele, as pata dele aqui, aqui vem a pata, é isso aí, acho que a pata dele é esses negocinho aqui ó. Eu acho que é um leão mesmo. Eu acho.

E: Posso te contar o que é?

B: Pode contar

E: É um trem.

B: Ai, é um trem?

E: Tá vendo isso que você tá vendo em cima?

B: Tô.

E: São as rodas, tá vendo ó?

B: Ah!

E: Isso que você ta tocando agora é um vagão. É o primeiro e aí vai ter outro. Toca aqui. Quantos vagões tem?

B: Eu achei interessante, gostei! Um, dois, três.

E: Isso, três vagões.

B: Aí vem o trem (e representou o barulho).

E: Embaixo tem as rodas e em cima, isso que você falou que era a boca (do leão), é tipo uma chaminé que sai fumaça do trem. Essa fumacinha, o desenho da fumaça.

B: Ai que legal meu. Olha. (ri)

E: Bacana né? Vou te mostrar o último agora, tá?

B: Ai que pena.

E: Ah, depois a gente vai trabalhar mais.

Bruno toca.

E: Esse aí tem bastante coisa.

B: É... Eu acho que esse é uma ilha.

E: Como você sabe?

$\mathrm{N}$ : O mar é aqui, outro, aí tem outro riozão, aí tem outros animais aqui, aqui são os animais. Aqui é o leão, aqui é o... (começa a rir) o outro...

E: Por que você tá rindo?

B: Não, nada. Outro leão, e o outro aqui. Não sei não mas eu acho que é uma ilha.

E: Você acertou, é uma ilha.

B: Uma ilha.

E: É uma ilha. Então vou te mostrar as coisas que tem nessa ilha. Isso que você ta passando a mão, tá vendo que é comprido?

B: Aham.

E: É uma árvore. É um coqueiro. Ilha geralmente tem coqueiro né? Igual praia.

B: Sei.

E: Já foi pra praia?

B: Já.

E: Então. Tem coqueiro assim, nas praias né? Geralmente. 
B: Certo.

E: Então esse é o desenho de uma ilha, claro, uma ilha bem pequenininha. Ela tem um coqueiro, isso que você achou que era um leão são as folhas do coqueiro.

B: E aqui ó, esse espação aqui ó?

E: Esse espação seria o céu. Vai ter uma linha quase no meio da folha.

B: Achei uma linha.

E: Isso, essa linha é linha do mar. Então o que ta pra baixo as linha seria o mar, o que ta pra cima seria o céu.

B: Ó que bonito, meu, olha.

E: Você vai ver que tem um círculo aí.

B: Círculo?

E: Achou o círculo? Esse círculo é a ilha. A ilha é um pedaço de terra que é cercado de água.

Achou o círculo?

B: Achei.

E: Então, esse círculo seria a ilha né? Um círculo de areia e tal.

B: Tem várias ilhas, Ilha do Governador, Ilha de Angras dos Reis.

E: Isso, você conhece varias ilhas, tá vendo? Então o que são essas ilhas? São pedaços de terra...

B: Cercado por água.

E: Cercado por água em todos os lados.

B: Que legal, queria quem sabe um dia ir pra lá.

E: É, então...

B: Quem sabe um dia pra lá...

E: Bem legal.

B: Que legal.

E: Gostou? Quer tentar fazer um desenho?

B: Quero.

E: Então vou te dar uma folha, aquele desenhador. Você pode desenhar umas dessas coisas que...

B: Tá bom.

E: Tenta fazer desenhos dessas coisas que nós vimos. Quer começar por qual? Pelo prédio, pela ilha, ou pelo trem?

B: É vou descrever, descrever pelo prédio.

E: Vai começar com o prédio?

B: Prédio.

E: Beleza.

Entrevistador coloca a prancha na mesa.

E: Isso aí é um grampo que eu vou usar pra prender a folha.

B: Igual a máquina de escrever.

E: Pode fechar. Você tem que apertar ele.

B: Ae, fechou.

E: Isso eu vou te dar aqui, com qual mão você escreve?

B: Com essa aqui.

E: Com essa aqui?

B: Com essa aqui.

E: Tá vendo que essa caneta tem uma ponta? Pontuda. Você usa ela para apertar o papel, ela não tem tinta, tá? Você usa ela pra apertar o papel e vai ficar marcado.

B: Olha, que legal!

E: Pode fazer. Você vai fazer o prédio?

B: Fazer um prédião. Vamos lá. Agora o mestre de obra vai construir um prédio. (ri) 
E: Vou segurar o papel aqui desse lado pra não dobrar, ta?

B: Que legal meu, olha, que bacana. Vou fazer um prédião, esse daí é muito pequeno, vou fazer um grandão. Opa. Que tem gente que fala assim "Nossa M., você é muito mal de desenho" e eu sou mal mesmo, eu não, assim, to percebendo que...

E: Cuidado pra não sair do papel.

B: Quanto custa essa caneta aqui?

E: Não sei.

B ri.

E: Deve ser caro eu acho. Esse kit ai, que você tá vendo, é a Tânia, ela trouxe da Espanha. Mas isso é fácil de fazer, você pode usar uma caneta comum, pegar um pedaço de madeira e nesse pedaço de madeira, sabe tela pra impedir mosquito de entrar na casa?

B: Sei.

E: Você cola uma tela.

B: Eu tenho uma telinha. A professora de Artes me deu.

E: Não, uma telinha, redinha de mosquito, não tela de pintura. Então, você prende essa tela na madeira e pronto, você pode usar qualquer caneta.

B: Que ela vai marcar. Faz um barulhão. Gostei meu. Sinceramente vou, quem sabe fazer um livro, um parque de diversões.

E: Você pode fazer isso em casa.

B: Bacana meu, ó.

E: Essa telinha.

B: Vou falar pro meu pai o que ele acha.

Bruno começa a desenhar.

B: Ah tá saindo perfeita.

E: Tá ficando bom. O que você fez até agora?

B: Um quadradão. Agora tenho que fazer os quadradinhos.

E: Ótimo.

B: Ó, bacana hein meu. Ó legal. Nota dez. Liga não que eu acho que errei essa linha, mas tudo bem.

E: Fica tranquilo.

B: Bom, deixa eu ver. Mais uma coisinha. Bom, o quadradão tá feito, agora faltam os quadradinhos.

B: Que legal meu, que bacana. Olha aqui, o primeiro apartamento. Agora vou fazer o segundo.

E: Faz.

B: Ae. Opa.

Continua desenhando.

B: O segundo tá pronto.

E: Ótimo, vai ter mais?

B: Pronto, terceiro. Esse terceiro ficou grandão.

E: Você fez um bem grandão e dois pequenininhos.

B: Bom, vou fazer se eu não me engano, uns, deixa eu ver o tamanho, um, dois, vou fazer logo três vai, precisamos de seis andares.

B: Ah não vou fazer um bem grandão agora. Só esse tomou conta do prédio.

E: Ô louco.

E: Opa, cuidado, se fizer tão forte rasga a folha.

B: Ah tá.

E: Essa folha não é muito grossa.

B: Pronto.

E: Beleza? 
B: Pera aí, falta mais um só, só isso aqui.

E: Tá.

B: Ô louco, tomou conta do prédio de novo.

E: Muito bom.

B: Pronto.

E: Gostei. Vamos tirar e vou pedir pra você fazer outro agora. Vou pegar mais uma folha.

B: Vou desenhar agora o parque de diversões.

E: Antes podemos o fazer trem ou a ilha? Qual você prefere?

B: O trem.

E: Então vai, tá aqui a folha já. Pode fazer. Deixa eu só facilitar uma coisa aqui pra você, vou tirar essa prancha, que ela fica dentro de um fichário.

B: Ah tá. Que legal.

E: Pronto, agora tá mais fácil.

B: Ai, ai. Por onde começar agora? Ah tá, vou primeiro pelo prédio.

E: Deixa eu segurar aqui pra você.

B: Eu fiz muito em cima meu.

E: Quer outra folha?

B: Quero, fiz muito em cima. Tudo bem. (ri)

Entrevistador dá a folha.

B: Aqui, pronto.

E: Segura a prancha aí senão ela escorrega.

E: O que você tá fazendo agora?

B: Vagão. Vagão pequenininho, né?

E: Hum?

B: Vagão pequenininho, né?

E: É.

B: Pronto, aqui é o segundo. Um do lado do outro. Depois eu vou fazer as rodas.

Continua desenhando

B: Também o que eu ganhei, eu faço esses desenhos com giz de cera então sai melhor, entendeu?

E: Entendi. Mas depois fica... Como é que você percebe o desenho? Fica marcado o giz?

B: Fica marcado o giz de cera.

E: Ah tá.

B: Mas não é muito, assim, como eu posso dizer, muito legal não, porque não sai do jeito que eu quero.

E: Assim você tá achando melhor?

B: Ô!

M continua desenhando

B: Ah, mais um, mais um vagão. Ah só falta mais um. Ah, só mais um vagão, só.

E: Vamos lá.

B: Pronto, agora vou desenhar as roda.

E: Então vai. Esses são os vagões que você fez.

B: São os vagões.

E: Tá.

B: Círculo.

E: Essa é uma roda?

B: Uhum.

E: Agora outra.

Entrevistador desenha outro círculo.

E: Pronto? 
B: Pronto!

E: Quer ver como ficou?

B: Quero.

E: Vira a folha aí.

B: Olha só.

E: Gostou?

E: Gostei. Aqui os vagões, aqui a roda, aqui a... Ai, ô ô...

E: Que foi?

B: Faltou um negócio dele.

E: Que negócio?

B: (Faz barulho de fumaça) A chaminé, a fumaça.

E: Quer fazer?

B: Quero.

E: Deixa eu virar aqui, que aí você faz.

B: Como é que ele vai...

E: Andar. Tó a caneta.

Bruno desenha.

E: Acho que tá bom, aí já tá comendo a folha.

B: Ah é, tá bom.

E: Vamos virar.

B. toca no desenho.

B: Agora sim.

E: Agora sim?

B: Agora sim.

E: Beleza. Agora vamos fazer a ilha?

B: Vamos.

E: Pode fazer.

Bruno inicia o desenho.

B: A linha dela. Os coqueiro...

Bruno continua a desenhar.

E: Esse é o coqueiro?

B: Uhum, falta as folha.

E: Tá.

B: Pronto! A ilha tá pronto.

E: Beleza. Aqui tá o coqueiro...

B: Coqueiro.

E: E essa linha?

B: Mais pra baixo é do mar e pra cima o céu.

E: Ótimo. Podemos fazer os outros desenhos?

B: Opa.

E: Qual você quer fazer primeiro?

B: O leão bem bravo.

E: Tá aqui ó. Pode fazer.

B: Fazer a jubona.

B: Ele vai ser bem bravo.

B: Mais essa partinha aqui. Toma.

E: Podemos fazer a montanha.

B: ok.

B: Vou desenhar essa parte aqui. Essa.

B: Agora vai aqui. Ó Ficou grande. 
E: E o que vamos fazer agora?

B: A nuvem, lá do céu.

B: Essa bolinha aqui, e mais outra.

B: Vou fazer duas, uma do lado da outra.

E: Tudo bem.

B: no céu tem muita nuvem. Cabô.

E: Você pode fazer a girafa?

B: Tô gostando dessa caneta aí.

E: Que bom! Então esta aqui.

B: Essa é só fazer um pescoção.

B cantarola enquanto desenha.

E: E agora só falta a árvore.

B: Vamo ae.

B: aqui, aqui, assim aqui.

E: Ótimo! Beleza, obrigado viu?

B: De nada.

E: Valeu! 
Desenhos Pré-teste: Bruno

Girafa

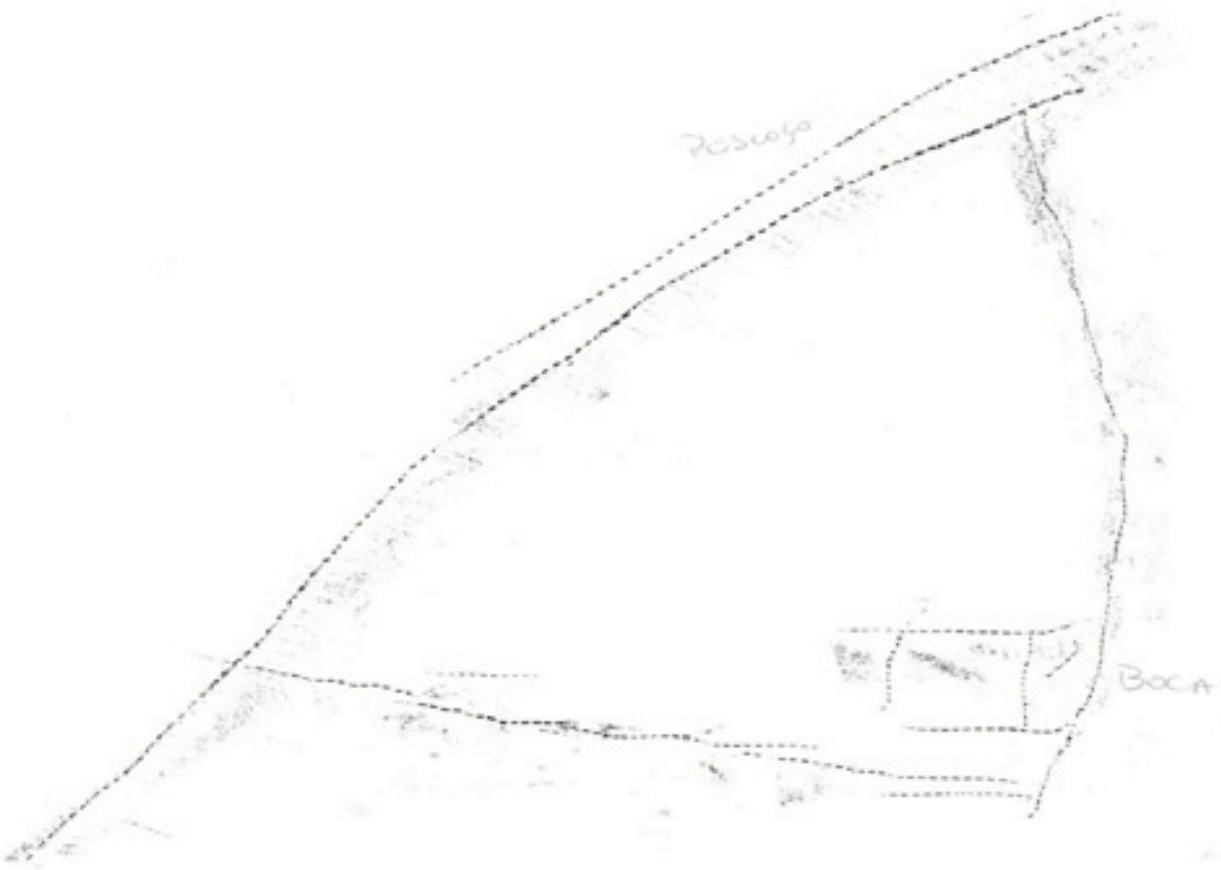

Nuvem

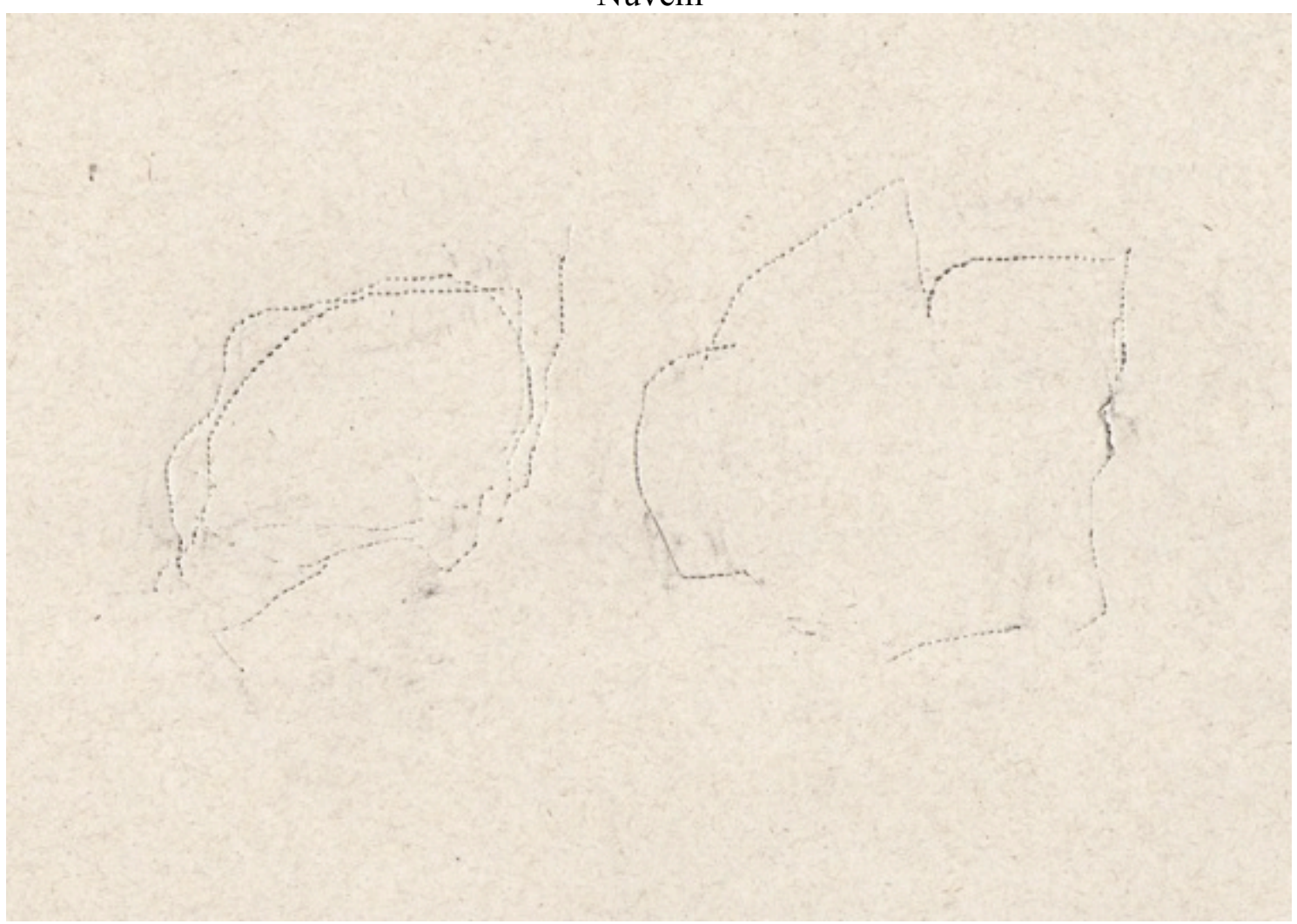


Montanha

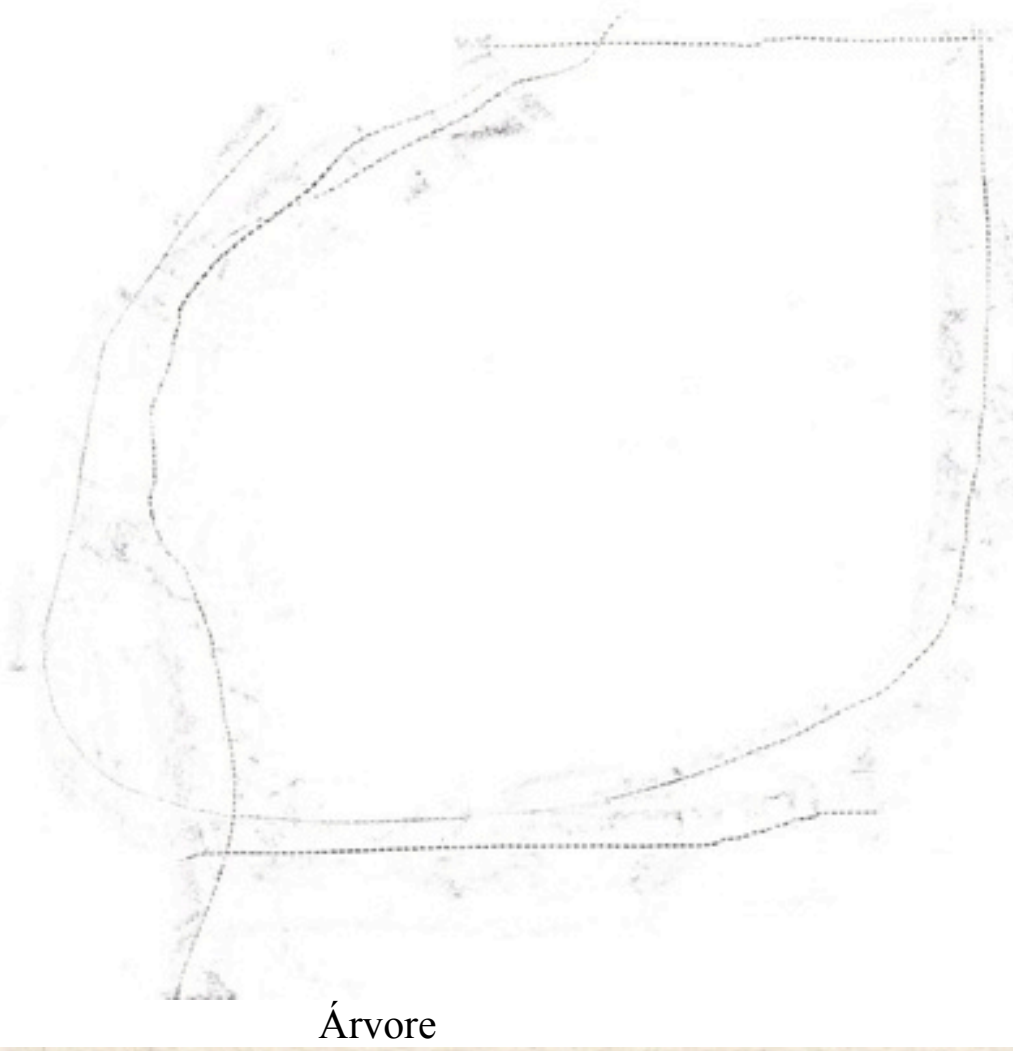


143

Trem

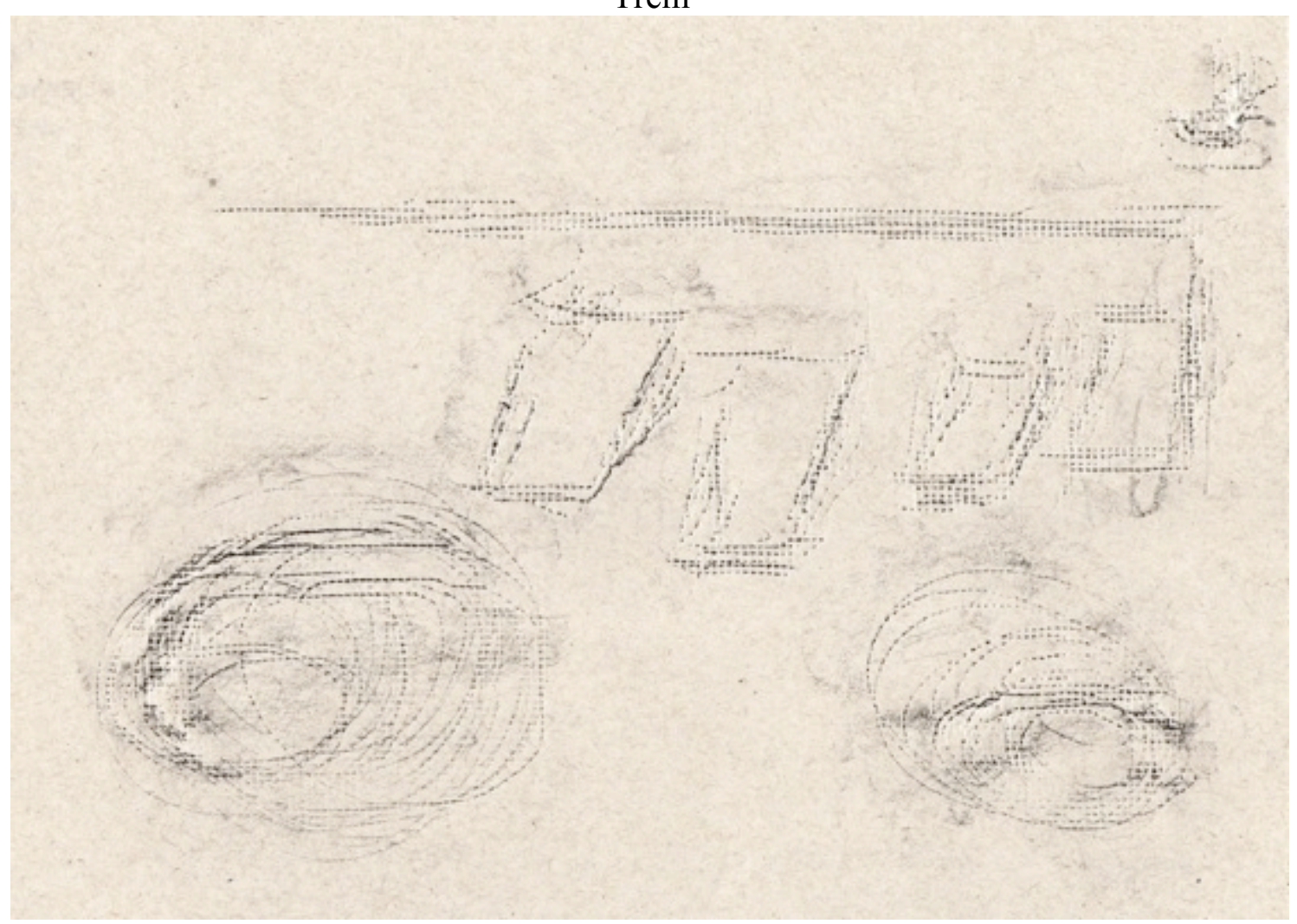

Leão

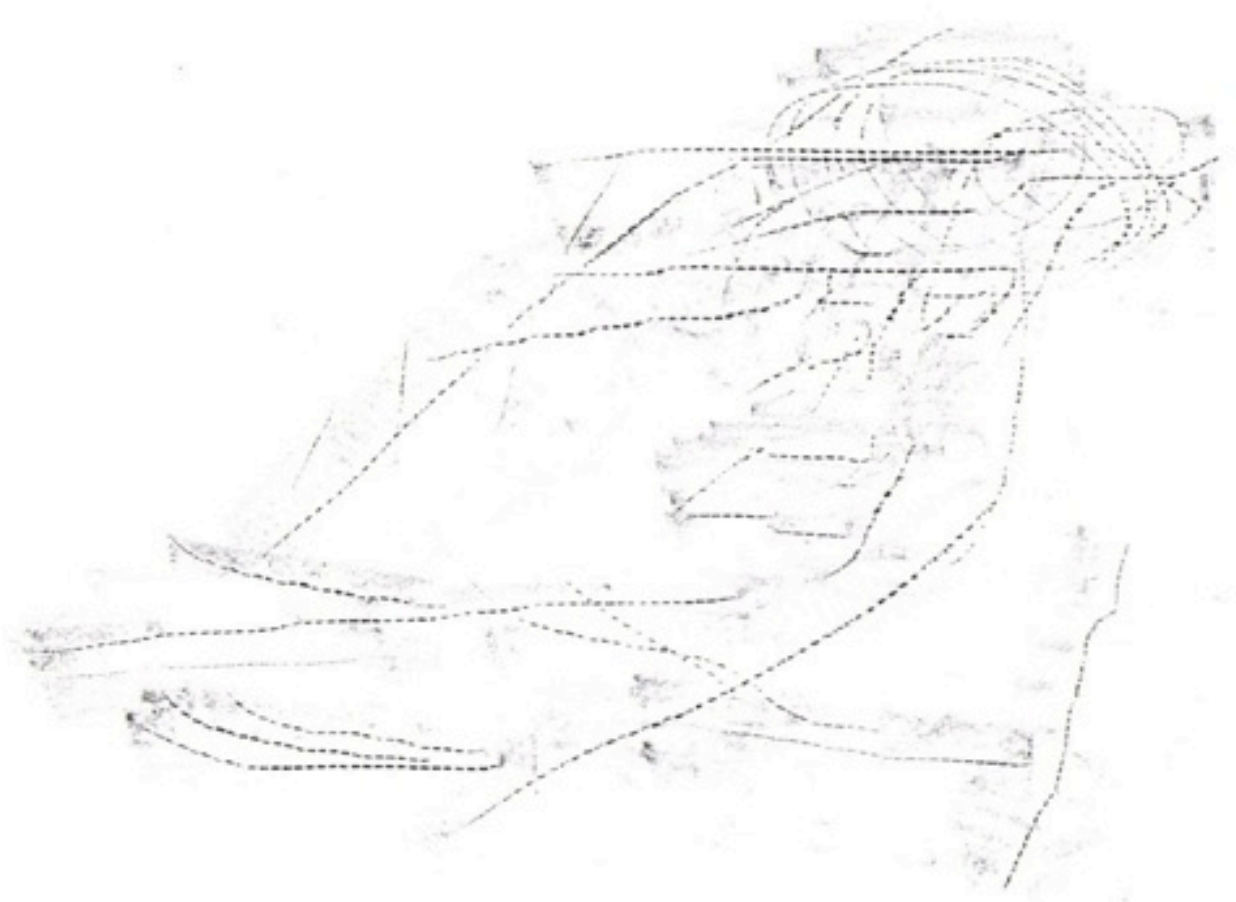


Prédio

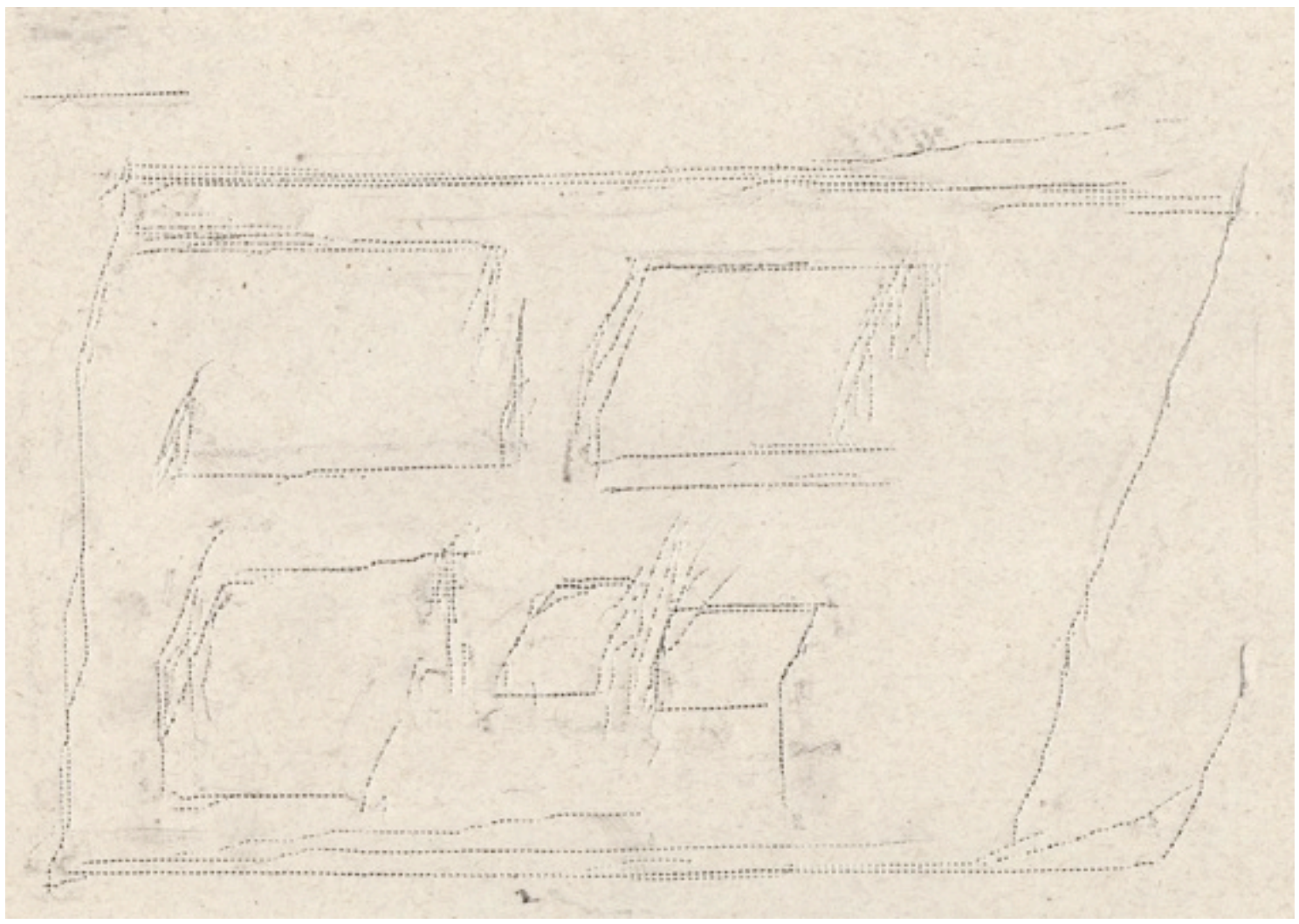

\section{Ilha}

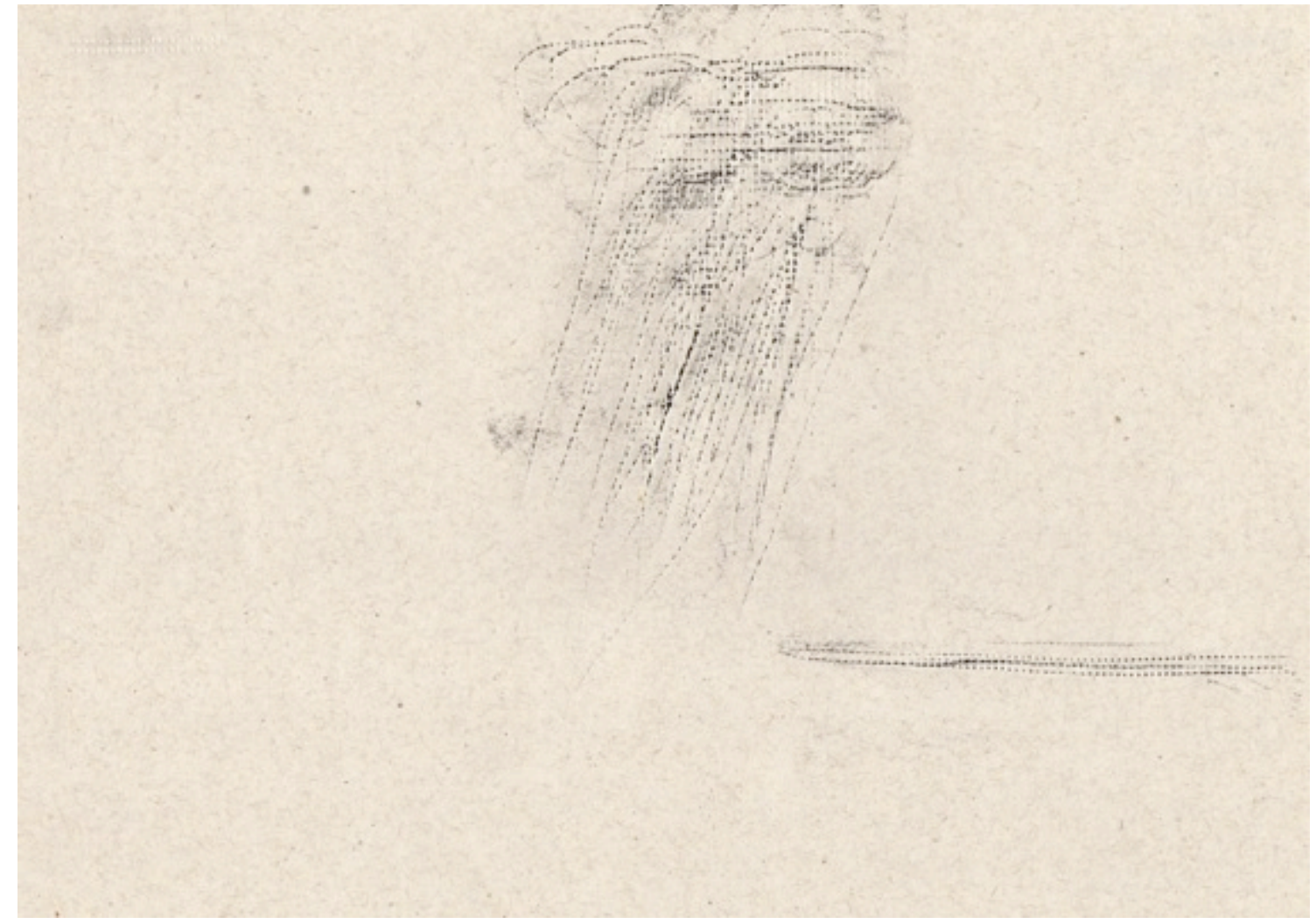




\section{Entrevista Pós-teste: Bruno}

E: Bom, hoje é nosso último encontro, então você lembra do que nós fizemos na primeira vez?

B: Ó, foi um prédio, um trem... Um prédio, um trem, uma montanha...

E: Assim, o que nós fizemos na primeira vez, eu te fiz algumas perguntas, pedi pra você definir algumas coisas né, e depois pedi os desenhos. Então hoje a gente vai fazer praticamente a mesma coisa, tá? Eu vou te perguntar algumas coisas, vou pedir pra você definir, pra você me dar algumas definições e vou te pedir pra fazer o desenho logo após as definições, tá bom?

B: Beleza!

E: Você responde da forma que achar correto, não se preocupa tanto em acertar ou errar, eu só quero ver como que você tá fazendo isso agora.

B: Sem problema nenhum.

E: Então beleza, vamos lá?

B: Opa!

E: Primeiro eu queria que você me explicasse o que é uma girafa.

B: Olha, a girafa, tem aquele pescoção grande, né? Assim, não é tão... É. Ela é grandona, que tem aquele pescoção e ela tem a parte de trás, a traseira dela assim, e ela, ela alcança as frutas das árvores.

E: Como assim a parte de trás?

B: A traseira dela, tem tipo umas patas assim, por trás dela. Aí...

E: Quantas?

B: Torno de, acho que é duas.

E: A girafa é um animal que tem duas patas, é isso?

B: (pausa) É, eu acho que é.

E: Entendi. Que mais?

B: Então, aí ela pega, ela consegue alcançar as frutas da árvore, que ela consegue comer.

E: Por que? Como que ela consegue alcançar?

B: Porque ela tem aquele pescoção grande. O pescoço consegue alcançar lá na árvore. Então ela consegue pegar a fruta.

E: Uhum. Você sabe o lugar que ela habita, o lugar que ela vive?

B: Ela vive na floresta.

E: Floresta, tá bom. Mais alguma coisa que você lembra sobre a girafa?

B: Não, não.

E: Você pode desenhar uma pra mim?

B: Posso.

E: Então vamos lá.

B inicia o desenho: Pata. (pausa) Árvore. (pausa) Folha. Aí vamos supor que o pescoço dela vai vir aqui... Pera aí. Ae, o pescoço dela vem aqui.

E: Ela come com o pescoço?

B: Não, com a boca. (ri)

E: Ah... Você falou que ela vai alcançar com o pescoço...

B: Então, ela alcança com o pescoço mas tem a boca que ela consegue pegar a fruta.

E: Ah bom.

B: A boca dela tá encostando na árvore. (pausa) E aqui vou desenhar o chão.

E: Tá. Onde que tá o pescoço que você falou?

B: Aqui, ó. Aqui tá a boca dela, aqui, ó, tem esse negociozinho aqui, e o pescoço dela aqui ó.

E: Cadê o pescoço?

B: Aqui ó. 
E: E essa linha que você desenhou aqui?

B: Essa daqui? Ela, aqui é o corpo dela, e aqui embaixo é as patas ó.

E: Quantas patas você fez?

B: Duas.

E: A girafa só tem duas patas?

B: Acho que tem quatro. Vou desenhar mais duas.

E: Tá.

B: Pera ae. Aqui a pata, aqui tá o chão, então mais duas pata dela aqui ó. Mais uma aqui.... Ae. Agora sim ó.

E: Fez quatro? Então só pra entender. Aqui tá o pescoço, é isso?

B: Isso, o pescoço vem aqui, berando aqui.

E: E essa linha aqui, o que que é?

B: Essa linha é o corpo dela.

E: Tá, ta legal. E essa linha que tá embaixo aqui do corpo?

B: É o pescoço.

E: Ah, entendi.

B: O pescoço vem grandão. Vem assim(faz um barulho com a boca)

E: E essa linha o que que é?

B: Ah, essa daqui é, aqui é como se fosse ela pegando a fruta da árvore. Aqui ó.

E: Entendi, tá certo. Posso pegar?

B: Pode.

E: Então vamos pro próximo. Você pode me dizer o que é nuvem?

B: Nuvem ela é uma... Então, ela é tipo um algodão, que ela fica no céu, aí da onde que a água ela, ela tipo evapora do rio, aí o que acontece, aí vai enchendo a nuvem, vai enchendo, enchendo, enchendo. Aí conforme vai enchendo vai escurecendo tudo. Quando chove aí fíca tudo escuro. Por exemplo, quando cai temporal assim, aí fica escuro, da onde a água vem assim, ela sobe, ela sobe, vai pela nuvem, aí vai enchendo a nuvem, vai enchendo, vai enchendo. Aí quando chega uma hora o raio solta aí libera a água e cai na terra.

E: E qual o tamanho de uma nuvem, você sabe?

B: Ah, tem nuvem grande, tem nuvem pequena. Depende, depende da evaporação da água. Se a água subir, se a água tiver na nuvem pequena aí pode aumentar ela, entendeu?

E: Uhum. E qual o formato da nuvem?

B: Ah ela é... Fazendo curva assim ó. (faz gestos)

E: Legal. Então vamos desenhar?

B: Bora.

E: Desenha uma nuvem pra mim.

B inicia o desenho: Assim ó...

B: Pronto, essa é uma nuvem.

E: Beleza, tá ótimo! Então vamos para o próximo. Você pode me dizer o que é árvore?

B: Então. Árvore, como eu falei a primeira vez, ela é, ela é um pé.

E: Um pé? Igual pé de gente?

B: Não é pé de gente, mas é pé. Não sei como é que fala, mas é pé. Todo mundo fala: pé-delaranja, pé-de-limão. Ela é uma... É, ela é bem alta, assim, depende, tem árvore alta e tem árvore baixa. Então ela tem vida, tem tipo um tronco, então esse tronco é de onde tem o sangue dela. Aí é onde tem folha, tem galho, tem fruta, tem passarinho...

E: E onde que fica a folha, a fruta, o passarinho?

B: Tudo na árvore.

E: No tronco?

B: Não, lá nos galho, lá em cima.

E: Os galhos ficam em cima? E o tronco, fica onde, então? 
B: Embaixo.

E: Embaixo, tá legal.

B: Onde fica... Onde que é a vida dela.

E: E como que é o formato do tronco? Como que ele é?

B: Ah, ele é... Eu acho que ele é meio redondo assim, aí tem tipo uns pau assim, tipo uns pau, aí tem um buraco aqui, onde que tem o sangue dela.

E: Tá legal, e a parte das folhas e dos galhos, como que é?

$\mathrm{B}$ : Ah, as folhas?

E: Isso.

B: Então, as folhas ela é assim ó (gesticula), tem folha que é assim, meia quadrada, assim ó.

Aí tem as fruta.

E: Tá ótimo. Vamos desenhar então a árvore?

B: Vamos.

E: Então faz o desenho da árvore com isso que você me falou.

B: Vamos lá, vou desenhar o chão. Eita vou desenhar eucalipto.

E: Como que é o eucalipto?

B: Essa daí é bem alta, só que ela não tem passarinho. Aqui é um pé dela, agora aqui vai descendo aqui.

E: Isso aí é o que?

B: Aqui é a... É o... (pausa) Desce. Um tronco agora, fica aqui ó. Esse tronco pequeno.

E: O que é isso que você tá desenhando aí?

B: É o tronco dela.

E: E essa outra parte, essa linha que você fez aí, o que que é?

B: Então aí é ela, a árvore

E: E o tronco não faz parte dela?

B: Faz ué, tá do lado. Aqui ó.

E: Mas eu não entendi o que você fez, você fez um árvore e um tronco, são coisas diferentes é isso?

B: É, eu coloquei o tronco embaixo dela.

E: Embaixo da árvore.

B: É.

E: Então a árvore não faz parte do tronco? É isso?

B: É, eu acho que é.

E: Tá. Pode continuar.

B: Ah eu vou desenhar as folhas.

B continua: Agora vou desenhar a maçã, vamos supor que aqui é uma maçã. Pronto! Esse é o pé-de-maçã.

E: Tá ótimo!

B: Parece que tem uma montanha, só que não é, ó. Aqui é onde desce ó.

E: Desce o que?

B: Onde o pessoal desce, aqui ó.

E: Pessoa desce?

B: É, ela vem se segurando por aqui ó. Ela vem aqui, aí ela vem da água descendo, descendo.

E: E como chama essa parte aí que ela usa pra descer? Qual o nome disso?

B: É, na verdade, na verdade é o pé dela, na verdade. É o pé, aonde a pessoa vem aqui desce. Aí para aqui no chão.

E: Tá bom. Posso pegar?

B: Pode.

E: Vamos para o próximo.

B: Árvore. 
E: Você pode me explicar o que é trem?

B: Então, trem é obtido por vagões

E: Obtido por vagões?

B: É, ele tem vagões. Então ele é o trem, ele tem vagões, ele anda nos trilho.

E: Como que são esses vagões?

B: São... É... São janela, são tipo um monte de quadrado, é... Muito grande. Depende do trem. Tem trem pequeno, tem trem grande. Então, aí ele tem... E ele é grandão também, tem trem pequeno e tem trem grandão, entendeu? Aí tem a janela aqui ó. Aí é onde tem as roda dele aqui.

E: A roda fica na janela, é isso?

B ri: Vamos supor que aqui é a janela, vai. A roda vem aqui embaixo, ó.

E: Aqui embaixo do trem, é isso?

B: Isso, e em cima aqui é um... De onde sai fumaça.

E: Entendi. Você falou que tem vagão. Quantos vagões tem o trem?

B: Depende. Tem trem que tem... Tem trem que quando ele é pequeno ele tem uns... Assim, em torno de quinze, em torno de quinze. Quinze vagão, vagões. Quando é trem grande tem vinte. Então aí ele tem, ele tem várias característica do trem. O mais grande tem várias janela né, é grandão. E o pequeno tem torno de quinze, dezesseis.

E: E como que esse vagões ficam organizados? Ficam do lado um do outro?

B: Um do lado do outro.

E: Um atrás do outro, um em cima do outro, como é que é?

B: Um atrás do outro.

E: Entendi.

B: Aí onde ta, aí vamos supor que tudo isso é o trem. Aqui é a cabine do maquinista.

E: Uhum, entendi.

B: Tem duas cabine, né? Tem uma aqui e outra aqui. Na hora que termina a linha, aí ele volta praquela cabine pro trem voltar pro outro lado.

E: Vamos desenhar então o trem?

B: Bora.

E: Vamos virar a folha aqui pra você ter mais espaço, coloquei na horizontal agora. Pode fazer.

B inicia o desenho.

B: Mais uma janelinha... Ae. Agora as roda do trem. Outra aqui também.

E: Quantas rodas vai ter o seu trem?

B: Duas.

E: Duas rodas?

B: A roda, ah é o negocio da fumaça aqui é. Pronto, esse é meu trem.

E: Tá ótimo, pode pegar?

B: Ó, igualzinho.

E: Vamos para o próximo. Você pode me dizer o que é montanha?

B: Montanha?

E: Montanha.

B: Tá, montanha ela é... Ela é um morro bem alto e tem várias, tem montanha de gelo e de... E de barro né. Ela é bem... Ela só... É...(pausa) E tem montanha que tem o pico mais alto na verdade. Então ela é bem alta.

E: Como assim tem o pico mais alto? Mais alto do que o que?

B: É o cume dela na verdade. É o cume.

E: Que é esse ponto mais alto, é isso?

B: É o ponto mais alto.

E: Tá certo. Vamos desenhar então? 


\section{B: Bora!}

E: Vamos lá. Pode fazer uma montanha do jeito que você me explicou.

B inicia o desenho

E: M explica essas partes aí.

B: É onde que é aqui ó, aqui é o cume. Aí vem, vem aqui, desce. Aí vem de novo aqui e sobe, entendeu?

E: Uhum. E onde que tá o chão aí?

B: Aqui ó, esse é o chão dela. Aí sobe por aqui ó.

E: Tá ótimo. Posso pegar?

B: Pode.

E: Vamos para o próximo então. Você pode me dizer o que é leão?

B: Leão? O leão é um animal carnívoro, ele come, ele come pessoas, tem aquela jubona assim

E: Tem juba, o que que é a juba?

B: O cabelo dele.

E: Aham. Que mais?

B: Aí ele fica, ele fica na floresta, aí tem as vezes que ele fica bravo.

E: Por que?

B: Por causa que quando se aproxima dele aí ele, aí ele pega, ele é mais rápido né.

E: Uhum.

B: Ele come carne, ele come pessoas, ele come animais, né.

E: E como ele é? Como é o corpo dele, ele é grande, ele é pequeno?

B: Ele, ah tem, é ele é grande. É... É muito... Ah ele, ele, o corpo dele na verdade é... É muito, eu acho que é muito peludo, eu acho.

E: Uhum.

B: Ele é muito grande.

E: Uhum. Mais alguma coisa?

B: Não, só isso.

E: Então vamos desenhar?

B inicia o desenho

E: Que parte é essa que você ta desenhando?

B: É o corpo dele. (pausa)A cabeça... Cabeça, agora o olho. Outro olho. Nariz. Bigode (ri). A boca. Que bocona hein. Ah é, e a juba. Pronto, esse é o leão.

E: Ótimo. Posso pegar aqui?

B: Pode.

E: Vamos para o próximo então. Agora eu queria que você me dissesse o que é prédio.

B: Prédio ele, ele é um... Ele é um lugar que tem vários andares, então, aí esses andares é onde que a pessoa mora na verdade, e tem salão, tem piscina.

E: No andar?

B: É, nos andares.

E: Cada andar tem salão e piscina, é isso?

B: Não, num andar... Não, assim, num é todos os andar, tem prédio que num tem, entendeu?

E: Que não tem o quê? Andar ou piscina?

B: Que não tem piscina. Mas tem prédio que tem, mas a piscina fica tipo numa área de lazer.

E: Aham. E os andares?

B: Ah eles fica tudo um em cima do outro.

E: Em cima um do outro?

B: É.

E: E como é que é o prédio? Que formato que ele tem? Que tamanho que ele tem?

B: Ah, o formato dele é.... Ele é muito, o tamanho... O formato dele na verdade ele é... É muito, é, tem formato grande e formato pequeno. 
E: Isso é o tamanho, mas e a forma dele como é?

$\mathrm{B}$ : Ah ele tem várias, várias, vários lados, né

E: Que mais você sabe sobre o prédio?

B: Ah acho que só isso só.

E: Então vamos desenhar?

B: Bora!

E: Então vai, desenha um prédio pra mim.

B inicia o desenho.

B: Agora vou fazer os apartamentos. (pausa) Mais um andar aqui. Ah é, embaixo fazer o térreo né

E: Quantos andares tem esse seu prédio?

B: Vou contar agora.

E: Tá.

B: Deixa eu ver, Um, dois, três, quatro. Quatro e o térreo.

E: Posso pegar?

B: Pode.

E: Vamos lá. O último agora. Você pode me dizer o que é ilha?

B: Então, ilha é um continente cercado por água.

E: Um continente cercado por água, é isso?

B: Não, quer dizer, é um lugar cercado por água.

E: Hum, que tipo de lugar?

B: Assim, rio, tipo uma divisão, aonde só passa barco e... Assim, se você quiser andar de barco, aí você tem que atravessar a ilha, aí se você quiser ir de avião...

E: Você passa de barco na ilha, é isso? Pro meio da ilha?

B: É, no meio da ilha. E ela tem o céu.

E: A ilha tem céu?

B: Não, tem céu de onde passa o avião, é lógico.

E: Ah tá.

B: E embaixo tem o mar.

E: E a ilha?

B: Então, ela tem tipo uma linha, que onde é o mar.

E: Acho que eu não entendi muito bem o que é uma ilha não. Você falou que tem mar, tem céu, e o barco passa no meio da ilha.

B: É, ele passa na ilha.

E: Mas o barco não fica na água?

B: Fica.

E: Então a ilha é água, é isso?

B: É, é água.

E: A ilha é feita de água?

B: É, ela é cercada por água.

E: Cercada por água, mas como que a água cerca a água? Isso que eu não to entendendo.

B: Então, é onde tem, tem,tem ilha, tem ilha que tem terra, aí sim é cercado por água, agora tem ilha que não em, entendeu, é só água mesmo, cercada por água mesmo.

E: Água cercada por água? Não fica esquisito isso?

B: É, eu acho que eu não sei muito bem mesmo o que que é uma ilha na verdade, mas pra mim é essa.

E: Entendi. Vamos tentar desenhar então pra ver se fica mais claro? Aí você vai me explicando. Vai lá.

B inicia o desenho: Vou fazer a linha aqui.

E: Essa linha é o que? 
B: Essa linha, tudo isso aqui é água, e aqui é o céu, entendeu?

E: Tá, entendi.

B: Aí o barco vem passando aqui, assim ó (faz um barulho como se o barco deslizasse). Aí o avião passa aqui ó, em cima... No céu aqui.

E: Entendi, continua aí. Vamos ver o que mais.

B: Agora vou desenhar uma árvore.

E: E a ilha cadê?

B: Aqui ó.

E: Mas aí não é água?

B: Aqui é água, aqui é o céu. Aí eu tô desenhando uma árvore aqui ó.

E: No meio da água?

B: É, na verdade... (ri) Na verdade em cima sim.

E: Tá.

B: Ae. Essa é uma ilha.

E: Onde?

B: Aqui ó. Aqui a árvore, pé de coqueiro, aqui é a água aqui e aqui o céu.

E: Tá. Tá bom, posso pegar?

B: Pode.

E: Então é isso, te agradeço, muito obrigado pela sua ajuda.

B: Que isso.

E: E aí, gostou?

B: Ô!

E: De fazer o desenho?

B: Muito legal. 
Desenhos Pós-teste: Bruno

Girafa

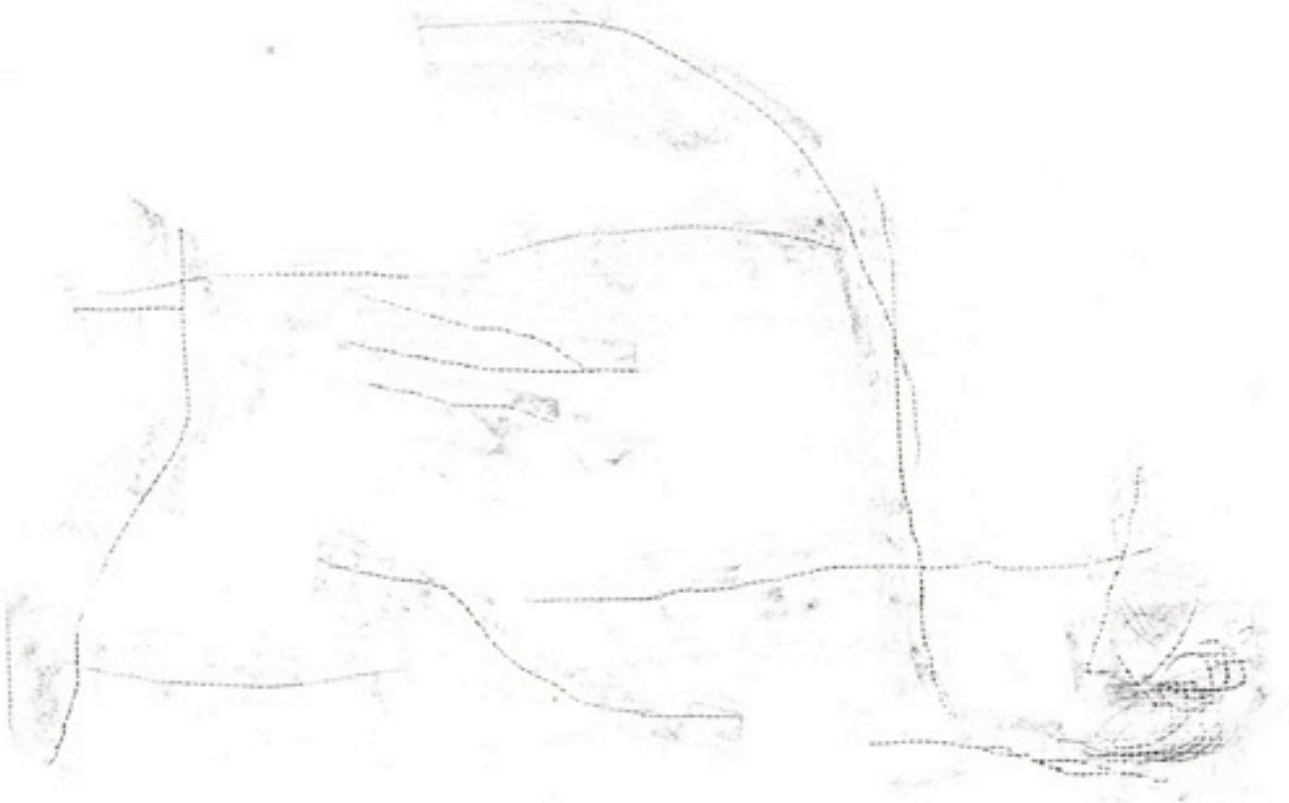

Nuvem 
Montanha

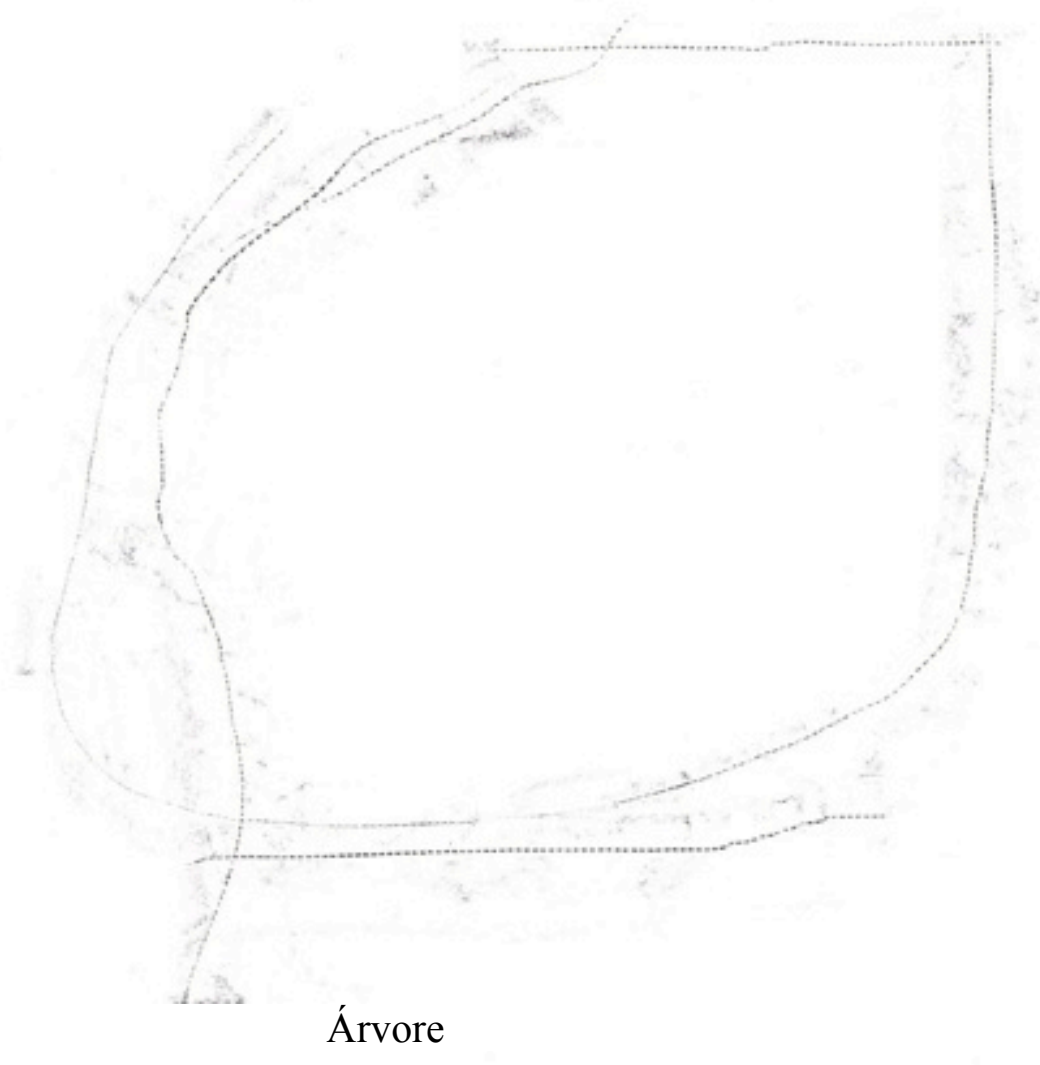

(3)

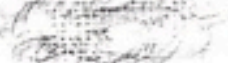

this
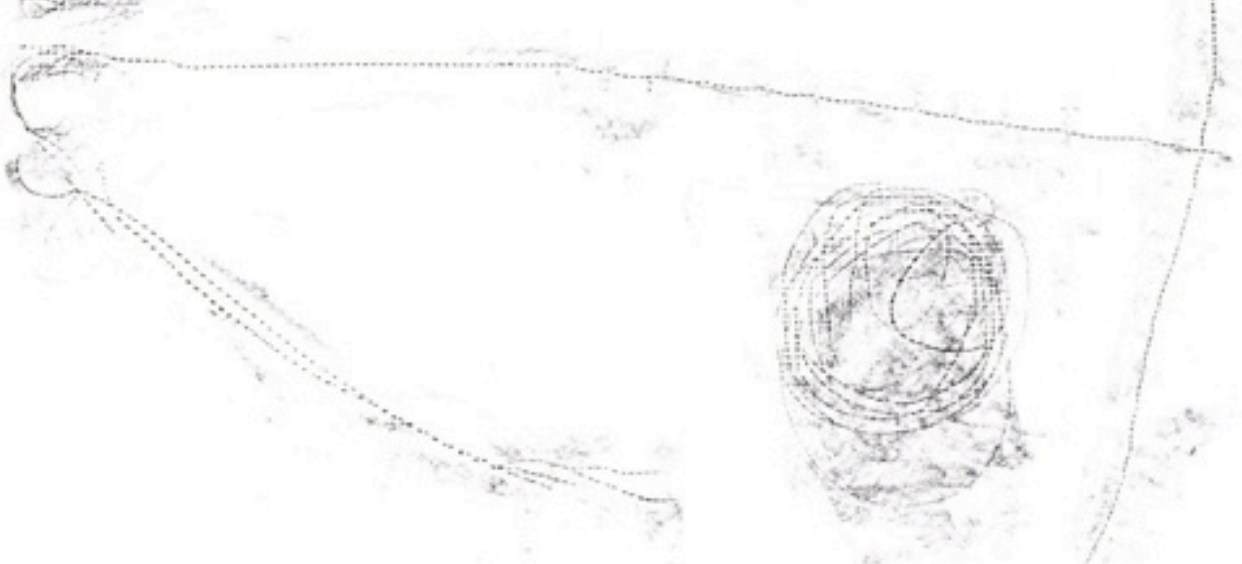
Trem

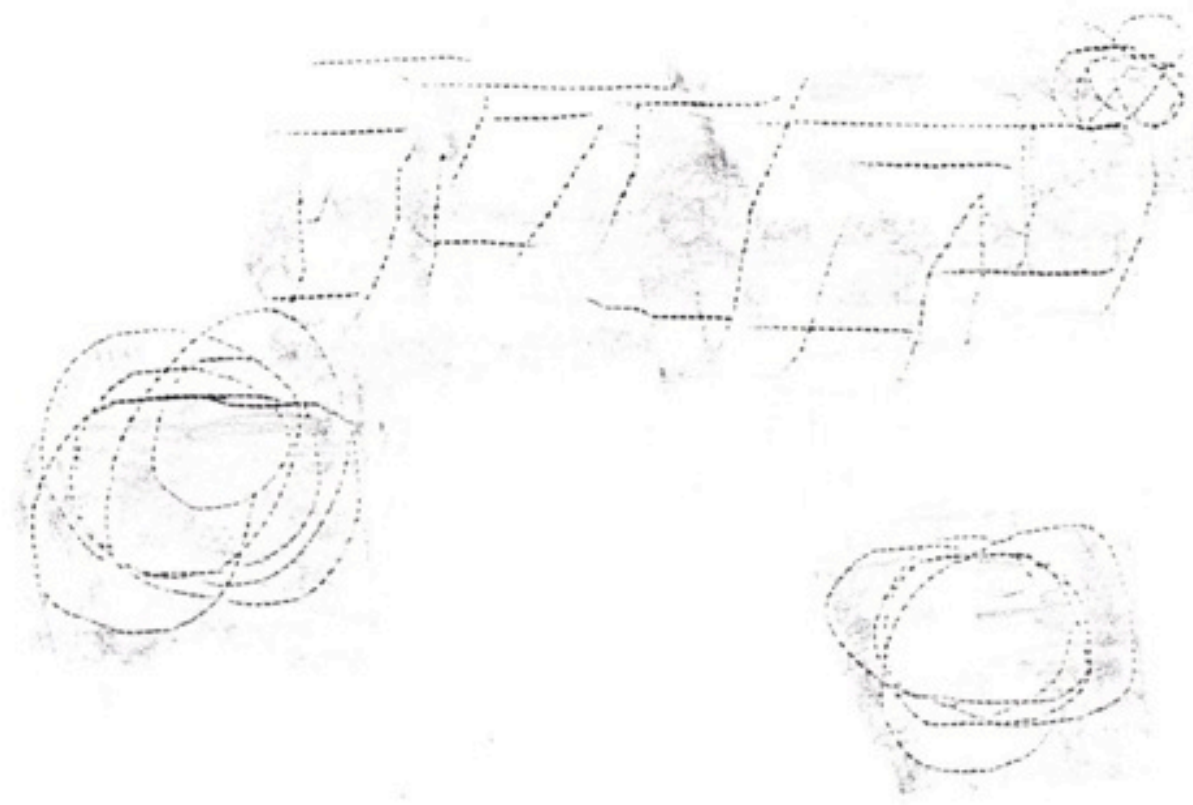

Leão

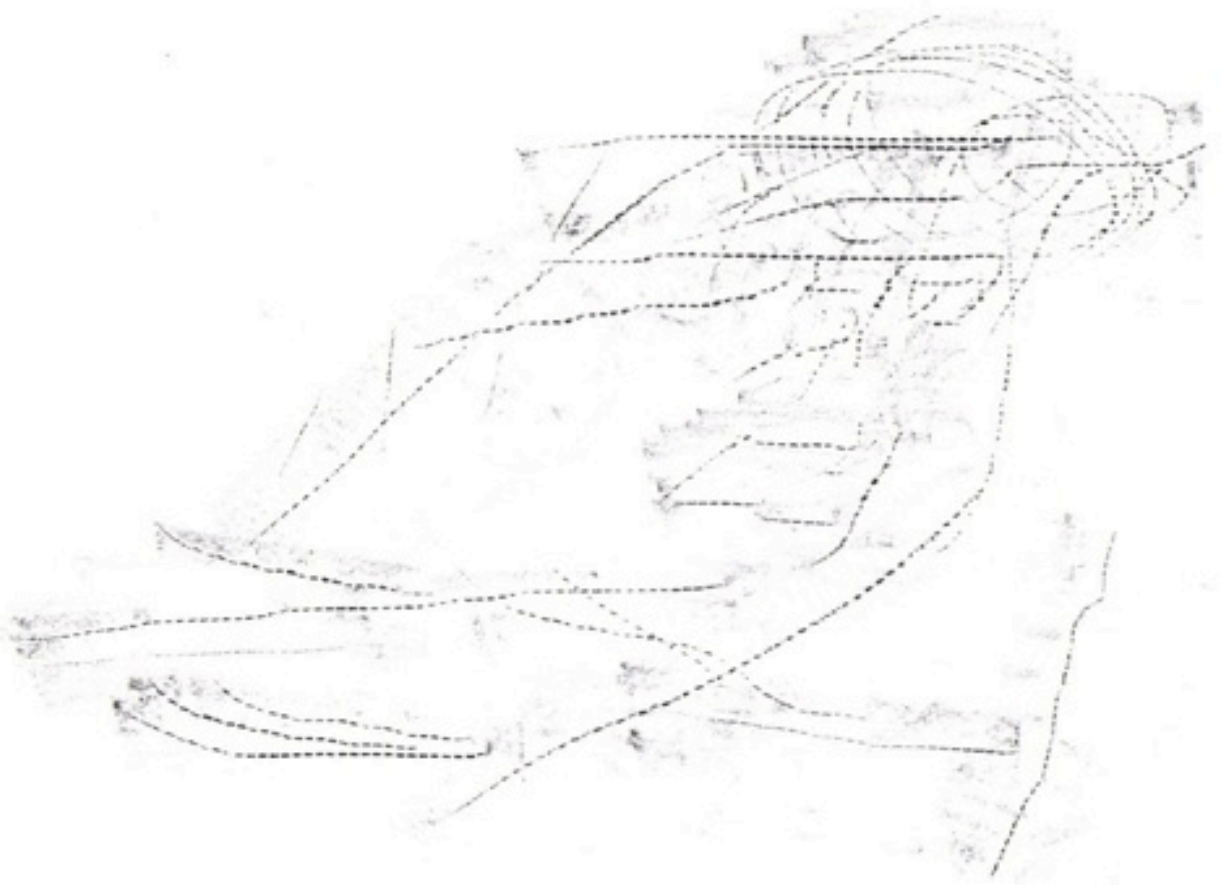


Prédio

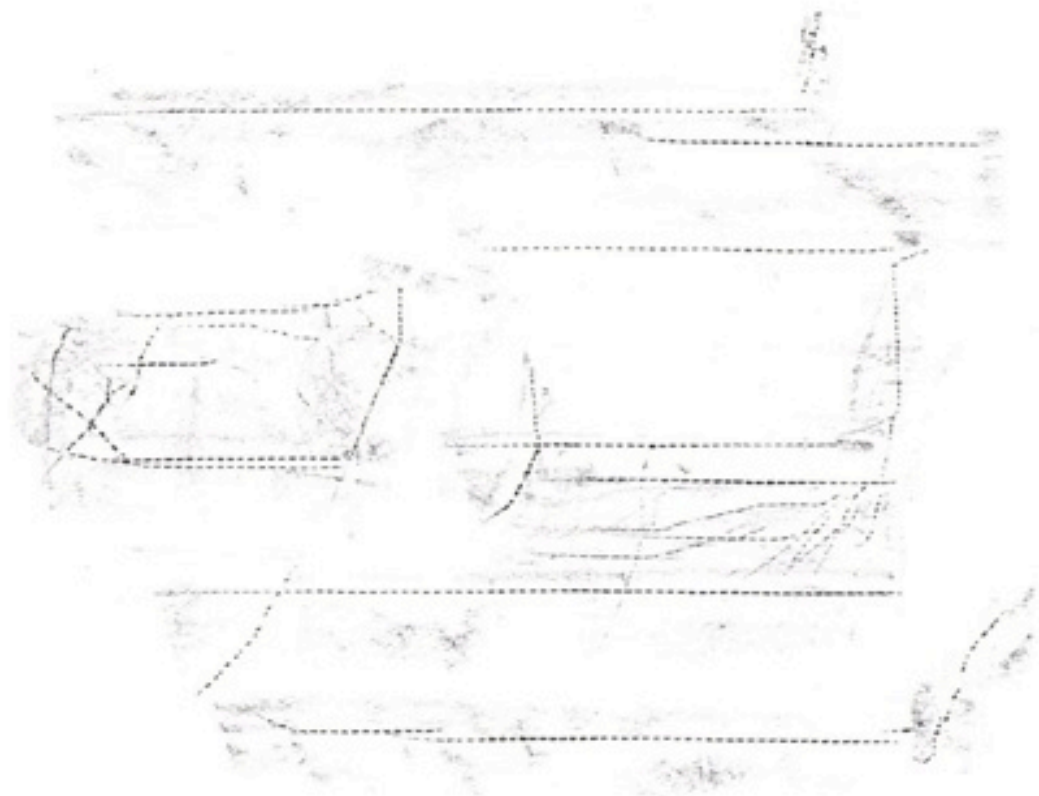

Ilha

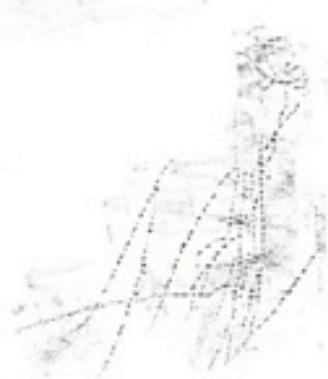




\section{Entrevista Pré-teste: Daniela}

E: Hoje vou te fazer algumas perguntas pra saber se você conhece algumas coisas, tá bom?

Você me responde na maneira que você quiser, não se preocupe em acertar ou errar, tá?

D: Tá bom.

E: Então vamos lá. Primeiro: Você poderia me dizer o que é uma girafa?

D: Um animal.

E: Uhum, como que é esse animal?

D: É muito bravo, tem quatro patas e uma tromba.

E: Quatro patas e?

D: Uma tromba.

E: Uma tromba? Muito bem. Você já viu uma girafa? Já foi no zoológico?

D: Eu já vi um monte de coisa.

E: Aham. E como que ela é.

D: Ela é assim. Ela é grande mas ela é assim ó, ela é má.

E: Ela é o que?

D: Ela é má.

E: Má?

D: Ela é igual um... Aquele... Parece aquele, aquele bichinho que ele é... Aquele bichinho, como que ele chama? Aquele bichinho que ele é bem grandão. Desse tamanho assim (gesticula), do tamanho da girafa, E ele é alto, ele é bravo.

E: É mesmo, a girafa é brava?

D: É.

E: Legal. Tem mais alguma coisa que você lembrou da girafa?

D: Hum?

E: Mais alguma coisa que você lembrou sobre a girafa?

D: Hum... Outro bichinho que ele é do tamanho da girafa também, o boi, que é do tamanho da girafa.

E: Tá legal. Vamos passar pro próximo? O que poderia ser uma nuvem?

D: Hum... (pausa) Pintar.

E: Oi?

D: Pintar.

E: Fala um pouquinho mais alto.

D: Pintar.

E: Pintar?

D: É.

E: O que?

D: A nuvem fica parecendo pintada.

E: A nuvem fica parecendo pintada?

D: Uhum.

E: Como que é uma nuvem?

D: Ela é azul.

E: Azul... E onde ela fica?

D: Fica lá no céu.

E: Fica lá no céu... Muito bem. Você conhece alguma coisa que parece uma nuvem?

D: Hum... Estrela.

E: Estrela parece nuvem? Ta bom, legal. Vamos para o próximo. D., o que poderia ser montanha?

D: Montanha? Hum... (pausa) Uma montanha.... Hum... Pode ser um brinquedo.

E: Um brinquedo? Que tipo de brinquedo? 
D: É... Um brinquedo montanha-russa.

E: Você já andou de montanha-russa?

D: Não, já andei de carrossel.

E: Ah... E como você sabe como é a montanha-russa?

D: Porque eu já vi outras crianças brincarem.

E: Uhum... Conta pra mim como é uma montanha-russa?

D: É... Ela é grande, tem rodas de carrinho e tem... (pausa) É, o que eu mais quem tem... Que tem no parquinho.

E: Hum... Você tem vontade de andar numa montanha russa?

D: Eu tenho.

E: Legal. Vou passar pro próximo, tá bom? O que poderia ser árvore?

D: Árvore? É... Nascendo.

E: Explica um pouquinho melhor, nascendo...

D: A árvore fica no... Ela nasce, depois fica bem grandona, lá perto dos passarinhos que os passarinho ficam embaixo da árvore.

E: Você gosta de árvore?

D: Eu gosto. Eu tenho uma árvore de brinquedo.

E: Você tem uma árvore de brinquedo? Como que ela é?

D: Assim ela é assim é: tem dois negocinhos que tem assim(gesticula), com um negocinho assim no meio e aqui. Pequenininha.

E: E uma árvore de verdade, ela é pequenininha também?

D: De verdade?

E: É.

D: É.

E: Ela é pequena?

D: Uhum.

E: Tá bom. Vamos lá. Passar pro próximo. O que poderia ser trem?

D: Trem? É... (pausa) Trem é estação.

E: Estação do trem?

D: É, porque daí, daí, eu já andei.

E: Hum. Como que ele é?

D: Ele é assim, ele é assim, é, assim, quando o piloto fala: A estação. Aí depois quando ele acelera (imita o som).

E: O que que é isso?

D: (ri) É o barulho, quando ele faz (imita o som).

E: Entendi. E você anda de trem muitas vezes?

D: Quando eu vou lá, quando eu vou lá pro meu pai.

E: Hum, na Fundação Dorina?

D. afirma com a cabeça.

E: Você vai de trem?

D. afirma com a cabeça.

E: Legal.

D: E você sabe por exemplo, se ele é grande, se ele é pequeno, como ele é?

D: Ele é grande.

E: Uhum, muito bem. Vamos passar pro próximo. J., o que poderia ser leão?

D: Leão? É... Ele é igual... Leão? O leão tem uma tromba também.

E: Tem uma tromba?

D: Tem.

E: Como que é a tromba do leão? 
D: A tromba dele é bem aqui ó (mostra a região do nariz e assopra) igual do gi... Igual da girafa.

E: Da girafa? Como que é uma tromba? Fiquei curioso agora.

D: Uma tromba parece um nariz. Parece um nariz. Daí, aí fica assim (mostra a região do nariz), aí, aí ele, ele faz (imita o som do elefante).

E: Esse é o barulho que o leão faz?

D: É.

E: Uhum. Que mais você sabe do leão?

D: Hum... Tem um chifre, parece do tamanho dele.

E: Qual que é o tamanho do leão?

D: Leão tem dois metros.

E: É mesmo?

D: Dois metros e meio. Eu já ouvi falar.

E: Já te falaram? Quem te contou? Quem te falou?

D: Eu vi falar na televisão.

E: Ah.

D: Tem dois metro e meio.

E: Ah, muito interessante. Bacana. Vou passar pro próximo. D. você poderia me dizer o que é prédio?

D: Prédio? Aonde tem muitas casas, onde mora muitas pessoa e lá... Lá perto da minha casa onde eu moro, que eu moro na rua de baixo agora, tem um prédio.

E: Tem um prédio? Como que é esse prédio?

D: É, é grande, mas aqueles que mostram na televisão, aquele que mostrou uma vez quando o menino morreu.

E: Você pode me descrever como era esse prédio?

D: É... (pausa) Tem cem metro.

E: Cem metro? Tem mais alguma coisa que você lembra desse prédio?

D: É... Tem prédio lá... Lá na... Onde tem um posto lá perto do mercado, que minha mãe faz... No mercado Dia. E tem o mercado Dia que tem lá, e o outro lá.

$\mathrm{E}$ : E tem prédios perto desses lugares, é isso?

D: Uhum.

E: Muito bem. Tá legal. O último. Você poderia me dizer o que é ilha?

D: Ilha?

E: Ilha.

D: (pausa) Ilha... É... (pausa). Ilha é o tamanho de uma...

E: Tamanho de uma...

D: Grandona.

E: Ela é grandona? Tamanho de uma...

D: De uma sala.

E: De uma sala?

D: É.

E: Que tipo de sala?

D: Sala normal.

E: E como que é a ilha? O que que tem numa ilha? Fala mais sobre ela.

D: É... (pausa) Tem... Mesas.

E: Tem mesas?

D: Mesas e cadeiras.

E: Mesas e cadeiras. Tá legal. E que tipo de lugar fica uma ilha, você sabe?

D: Não.

E: Não? 
D: Não.

E: Tá bom. Beleza D., essas eram as perguntas que eu queria te fazer. Agora eu vou te mostra três desenhos que representam essas coisas que eu te perguntei, tá? Esses desenhos tão em relevo, pra você sentir com a mão, tá?

D: Uhum.

E: Eu quero que você toque, que você tente descobrir o que é, senão eu te conto, tá? Ó, coloquei na sua mesa, na sua frente.

D toca.

E: É uma das coisas que eu te perguntei, vê se você consegue descobrir. Dá pra sentir? (pausa)

E: Alguma pista? Que que será que é isso?

D: É... (pausa) Casa.

E: Parece uma casa? Por quê?

D: Porque tem janela.

E: Porque tem janela. Teve uma das coisas que eu te perguntei que tinha janela também, você lembra o que era?

(pausa)

E: Lembra?

D: É...

E: O que que é isso aí que você tá passando a mão? O que parece?

D: Parece um... É... Quadrada... Aquelas coisinhas quadradas..

E: Como é que chama essas coisinhas quadradas?

D: É... (pausa) (ri) Bambolê.

E: Bambolê? Parece um bambolê? Então, lembra que você falou que tinha janelas? Vou pegar sua mão, tá, pra te mostrar. Tá vendo que tem uma aqui e em cima tem outra? Aqui embaixo, ó, isso que você tocou é uma porta, e aqui são as janelas. Isso aqui do lado, ali ó, do lado da janela, um espaço, uma reta grande, é a parede, aqui é o chão e do outro lado tem outra parede igual, viu? Isso é um prédio. Lembra que você falou que o prédio tem uma casa em cima da outra?

D: Uhum.

E: É isso. Posso passar pro outro? Me dá? (a folha) Vou te mostrar o outro, tá?

E entrega a folha.

E: Vê se você consegue decifrar o que é esse desenho.

E: O que que você tá sentindo aí?

D: Aqui (pausa). Um metrô.

E: Muito bem. Como você sabe?

D: Porque tem várias portas.

E: Tem várias portas? Onde é a porta, mostra pra mim.

D: Aqui.

E: Hum, legal. E isso aí embaixo, que você tá tentando decifrar o que é?

D: É... A roda.

E: A roda, muito bem. Muito bem, posso te mostrar o próximo já?

E entrega a folha.

E: Esse é outro.

$\mathrm{D}$ ri: Eu to meio boboca.

E: Que?

D: Eu (ri).

$\mathrm{E}$ : $\mathrm{O}$ que que tem você?

D: Eu to boboca.

E: Por quê? 
D: Eu to boboca.

E: Por que? O que você fez?

D: Não sei. Eu tô meio atrapalhada.

E: Ah .... E aí, conseguiu?

D: É... (pausa)Uma nuvem.

E: Uma nuvem?

D: É.

E: Nuvem... Não exatamente. Esse eu vou descrever pra você, tá? Esse lugar que você tá com a mão aí são as folhas de uma árvore, tá ali em cima, ó. Desce um pouquinho o dedo, você vai ver o tronco dessa árvore, e aí embaixo é areia. E você vai ver que tem uma linha dividindo a folha ao meio, essa linha é a linha do mar. Aí é um pedaço de terra, com esse círculo aí, isso, que é cercado de água por todos os lados, por isso que eu fiz uma linha pra representar o mar. E esse é um coqueiro, geralmente as ilhas tem coqueiros, e aí eu fiz um coqueiro pra mostrar. Dá pra perceber?

D: Dá.

E: Que legal. Então, beleza, D. Pra terminar, eu vou pedir pra você fazer uns desenhos pra mim, pode ser?

D: Uhum.

E: Alguns desenhos. Olha, você já utilizou desenhador?

D: Ahn?

E: Você já utilizou um desenhador?

D: Uhum.

E: Então vou colocar aqui na sua frente um desenhador. Põe a mão pra você sentir. Tá vendo, isso aí é uma tela, parecida com aquela tela de pintura que você me mostrou, e essa redinha aqui é pra marcar o desenho, tá? Então você vai desenhar com uma caneta especial, vai passar por cima do papel e depois quando você virar o papel vai tar marcadinho, igual os desenhos que eu te mostrei. Tá bom?

D: Uhum.

E: Então, dos três desenhos que eu te mostrei, ilha, trem e prédio, qual que você quer tentar desenhar primeiro?

D: (pausa) Hum...

E: Deixa eu por uma folha aqui, dá licença. Trem, prédio ou ilha?

D: Trem.

E: Vamos desenhar o trem. Vou te dar uma caneta, com qual mão você usa pra desenhar?

D: A direita às vezes, às vezes com a esquerda.

E: Bom, você que sabe. Essa caneta tem uma ponta, ó a ponta dela, ela que marca o papel, ta? Então pode... Você tem que fazer um pouquinho forte pra ficar marcado. Você vai desenhar o trem? Então vai lá, pode começar. Pode fazer forte, senão não vai ficar marcado, tá?

D desenha.

E: Isso aqui que você desenhou embaixo o que que é?

D: É roda.

E: Ah! E em cima?

D: Outra parte do trem.

E: Muito bem. Vou só marcar aqui o seu nome, ta bom? Vou te dar outra folha. Você pode desenhar um prédio pra mim agora?

D: Uhum.

E: Pera aí que eu tô pegando uma folha aqui. Deixa eu fechar aqui. Pode desenhar. Um prédio agora.

D começa a desenhar e ri: Eu ia usar de ponta cabeça o lápis. Ai ai...

E: O que são essas coisas que você tá desenhando? 
D: Ahn?

E: O que são essas coisas que você tá desenhando? Esses quadrados?

D continua desenhando

D: Vou fazer a porta. É assim.

E: Muito bem. Eu só queria que você me explicasse os detalhes, pode ser? Você pode me explicar os detalhes desse? Eu vou virar pra ficar mais fácil de você ver, ta? Pronto, ta aqui.

Me explica esse desenho então. Esse que você fez. (pausa) O que que é isso?

D: É um prédio.

E: Legal. Eu vi que você fez uns detalhes aqui, ó, por exemplo isso aqui. O que que é isso?

D: Uma janelinha.

E: Uma janelinha. E a porta onde é que tava mesmo?

D: Não tá aqui?

E: Deixa eu ver. Ah, ficou do outro lado porque eu virei o desenho, ó, dá licença, tá aqui né?

D: Uhum.

E: Muito bem, gostei do seu prédio. Agora vou pedir pra você desenhar a ilha, pode ser?

D: Uhum.

E. coloca a folha enquanto D. tenta fechar, consegue com a ajuda de D.

E: Pode desenhar a ilha.

D: Vou ter que fazer uma ilha bem grande.

E: Então faz.

D. começa a desenhar.

E: Que que você ta fazendo agora? Explica pra mim, que traço é esse que você ta fazendo?

D: Uma ilha.

E: Que parte da ilha é essa?

D: Ahn?

E: Que parte da ilha é essa que você tá desenhando?

D: Uma parte bem grandona. (pausa) Prontinho.

E: Prontinho? Muito bem.

Daniela mexe no prendedor.

E: Aperta e empurra pro lado (para desprender a folha). Isso.

E: Podemos fazer os outros desenhos?

D: Uhum.

E: Qual você quer fazer?

D: Ahn?

E: Que desenho você quer fazer?

D: Você que pede.

E: Pode ser a girafa.

D desenha.

E: agora podemos fazer a árvore.

D desenha.

E: O que você está fazendo nessa parte?

D: A árvore.

E: Agora podemos fazer um leão?

D: Tá. (depois) Pronto.

E: E agora quer fazer montanha ou nuvem.

D: A nuvem.

D desenha.

D: Agora vou fazer a montanha.

E:Obrigado viu D. Por hoje é só. Gostou?

D: Uhum 
Desenhos Pré-teste: Daniela

Girafa

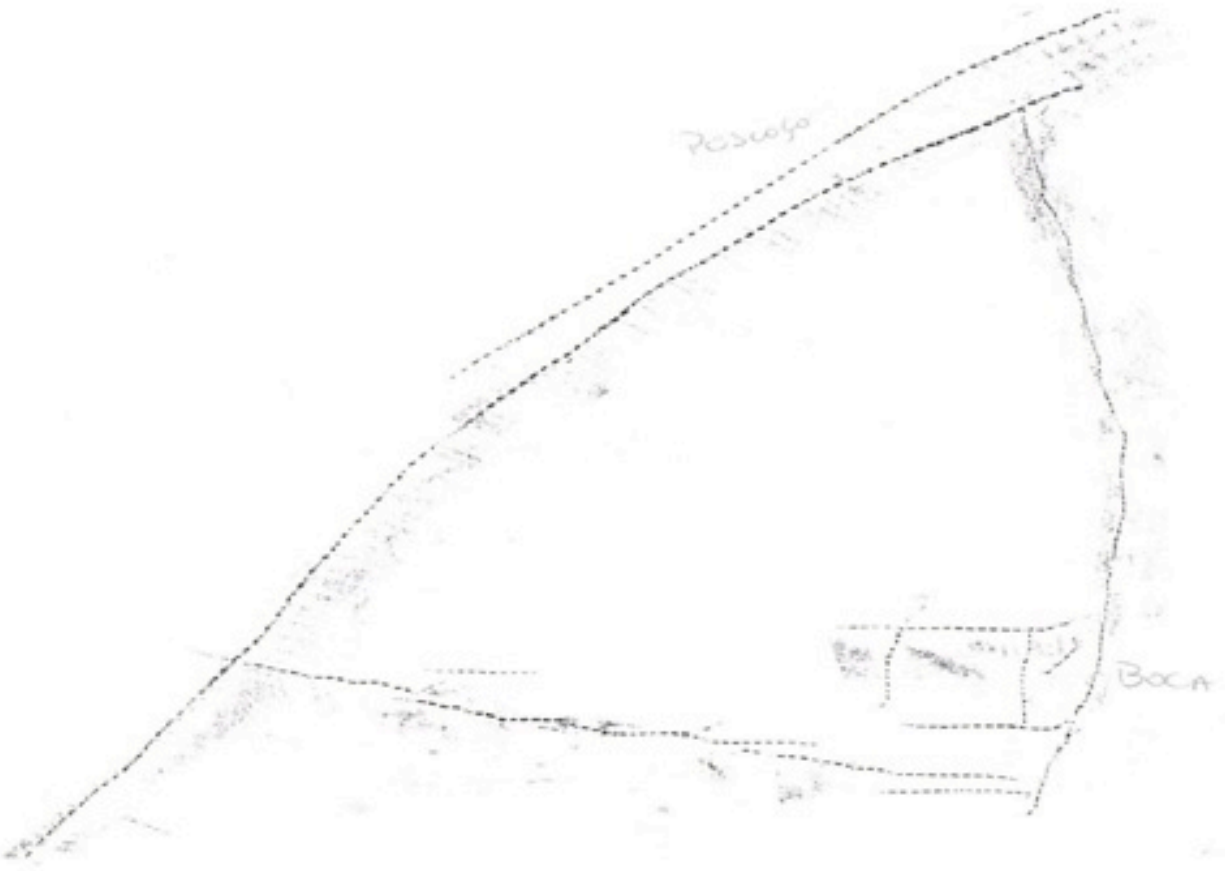

Nuvem

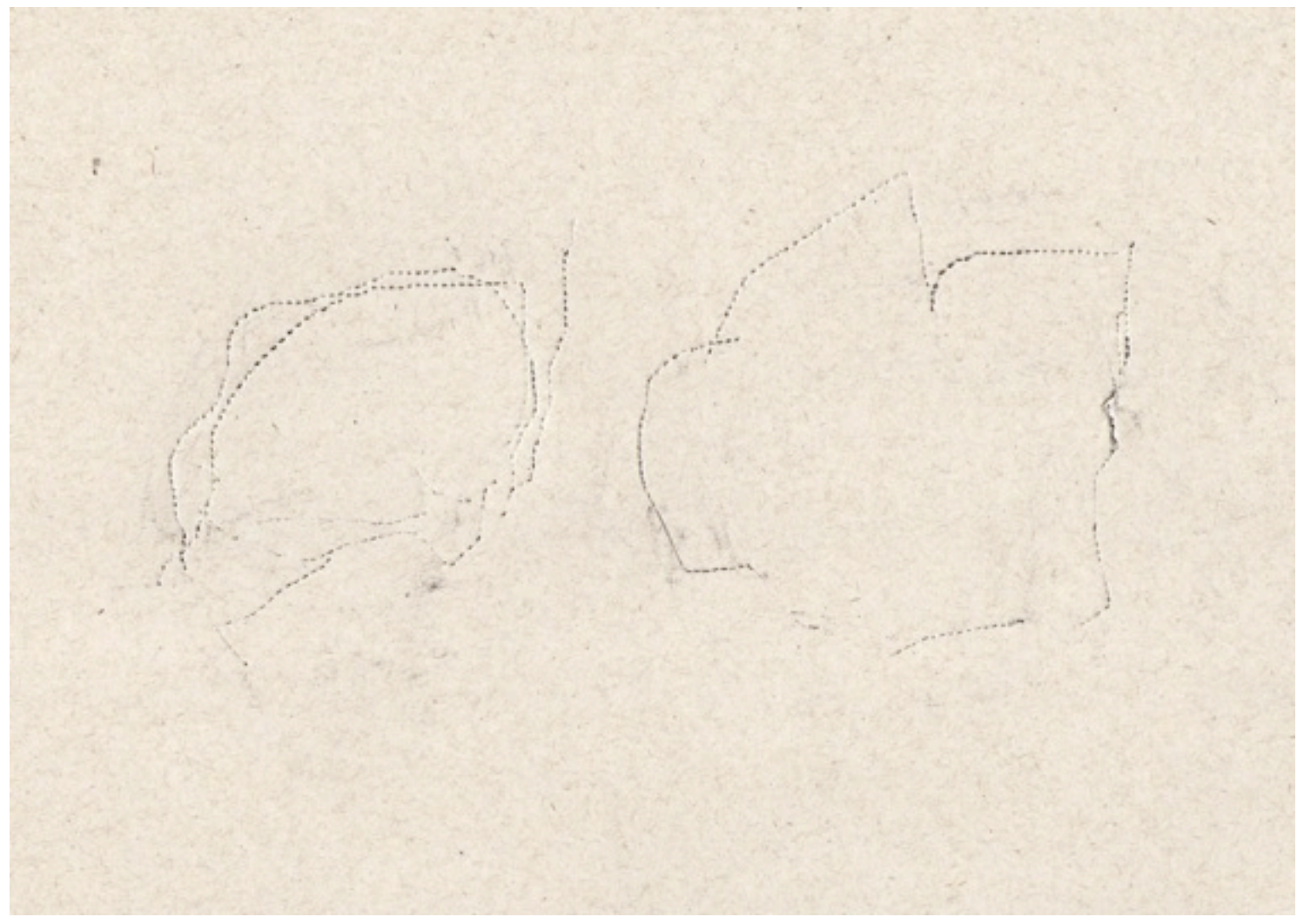


Montanha

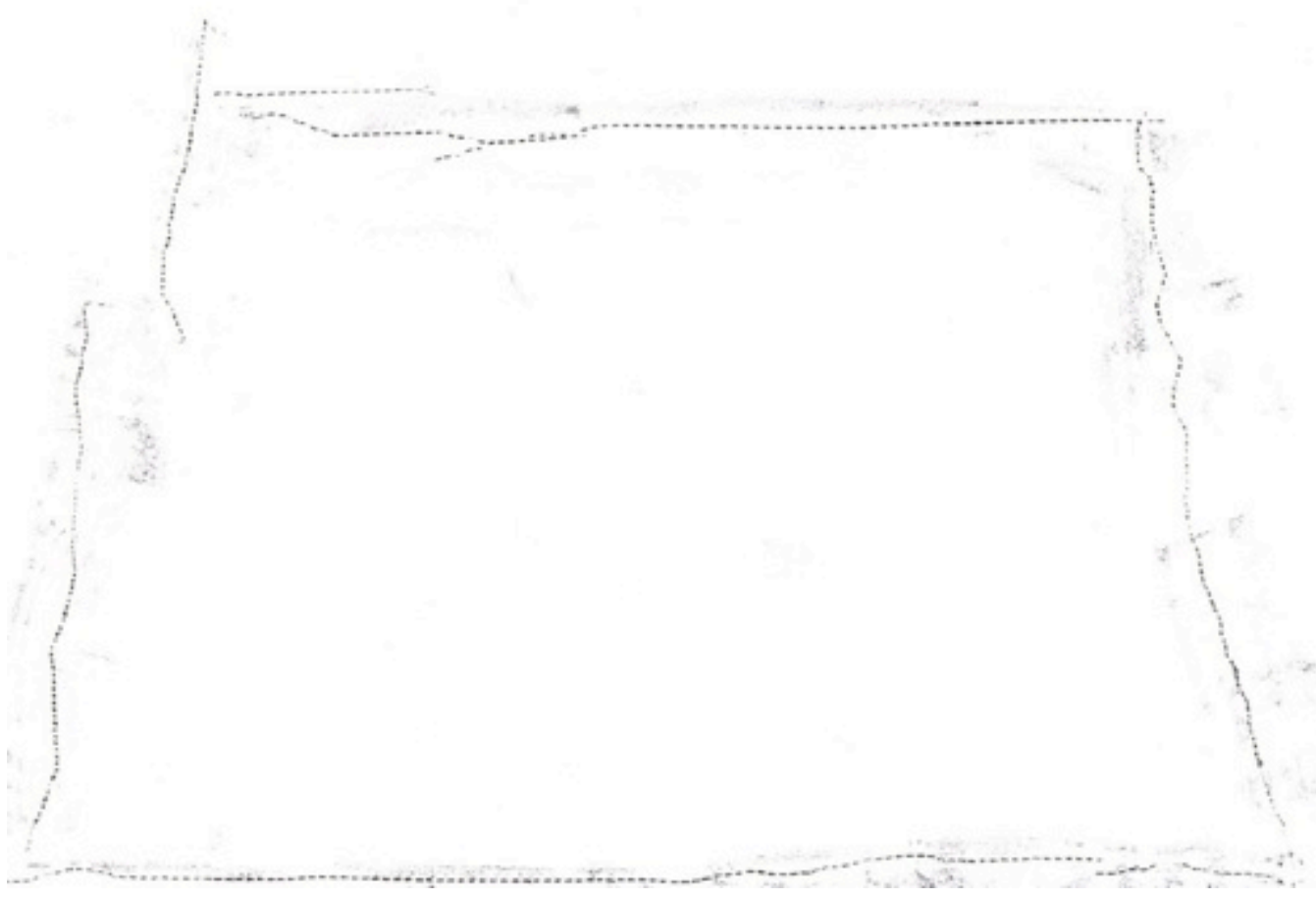

Árvore

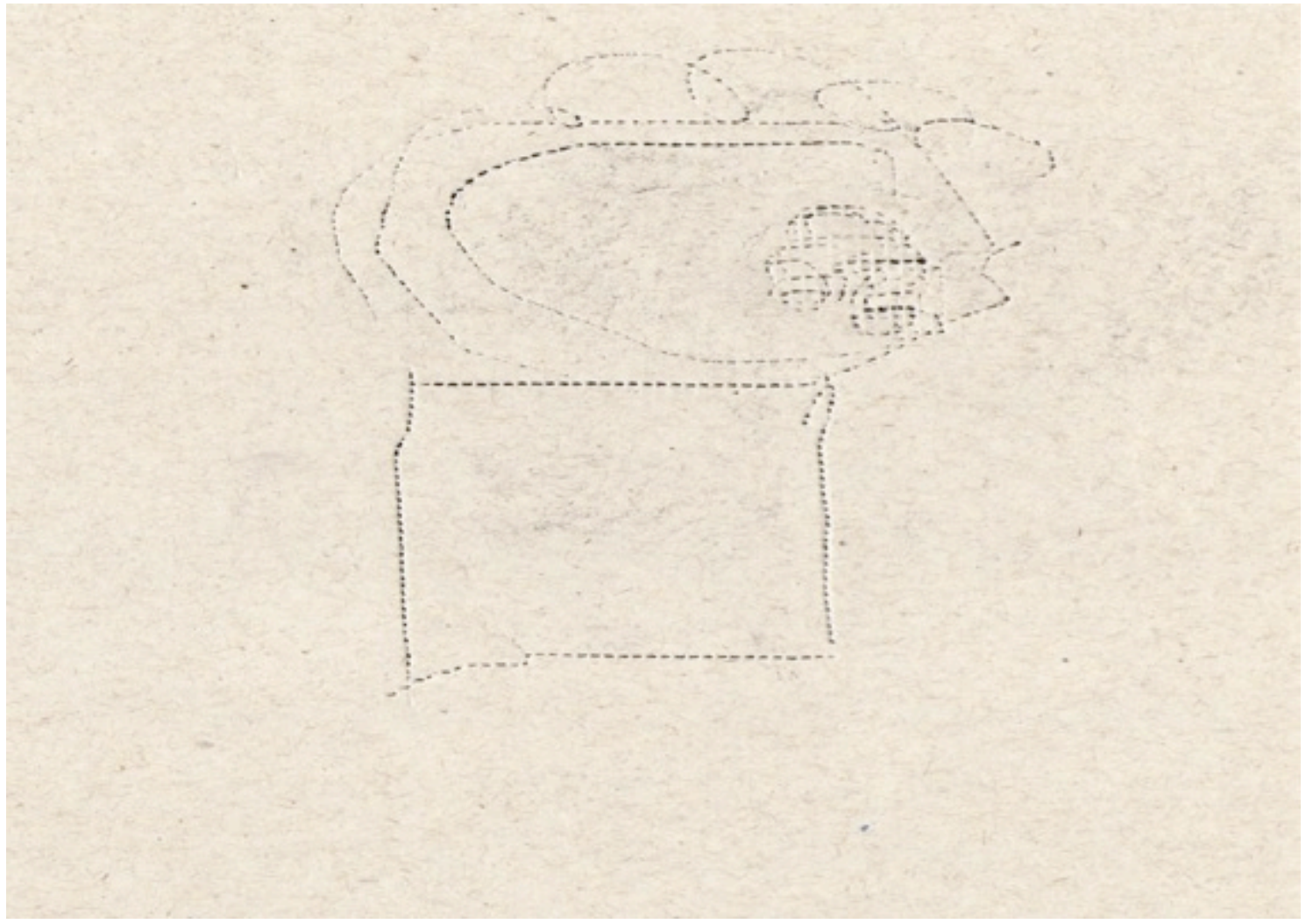




\section{Trem}

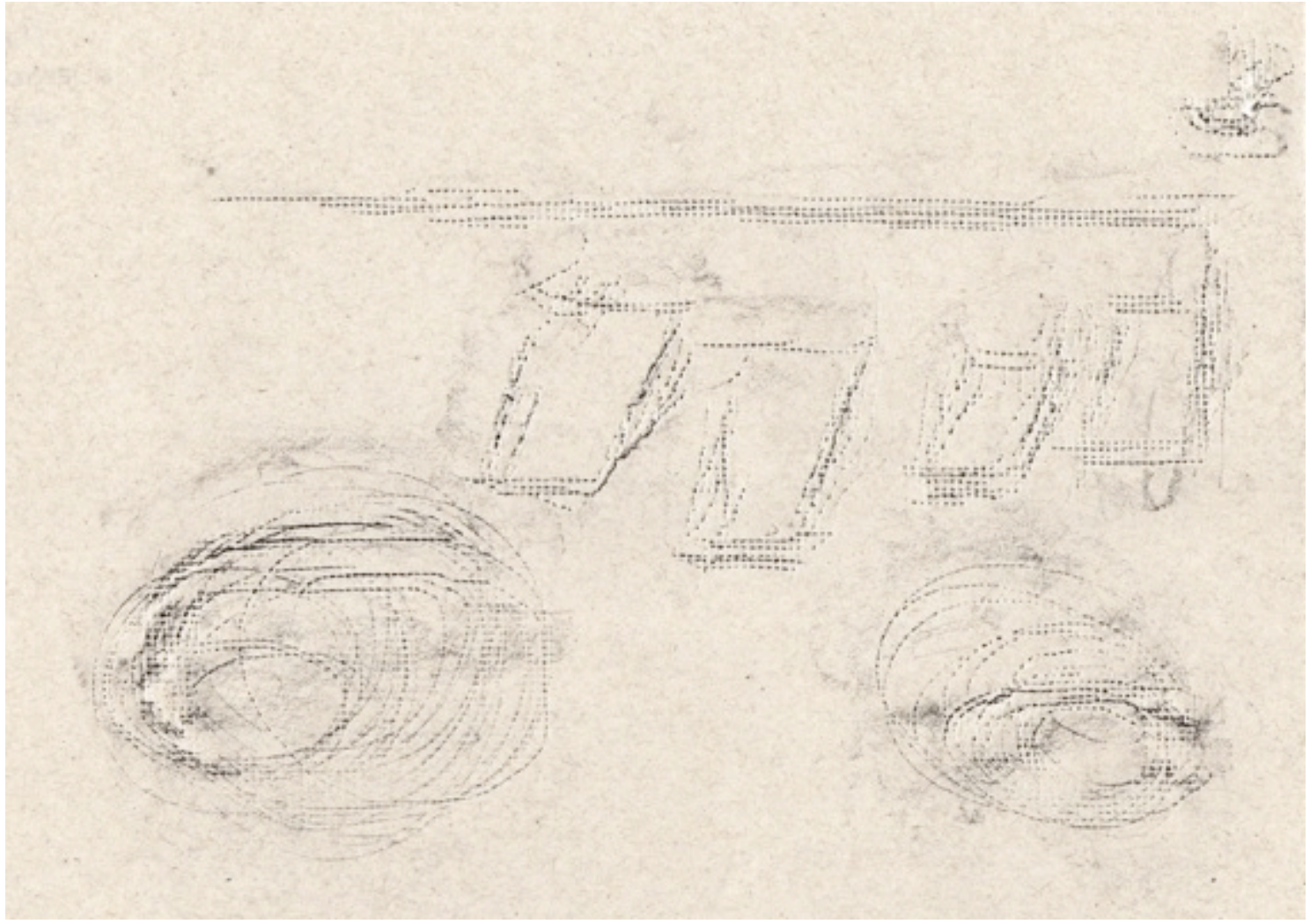

Leão

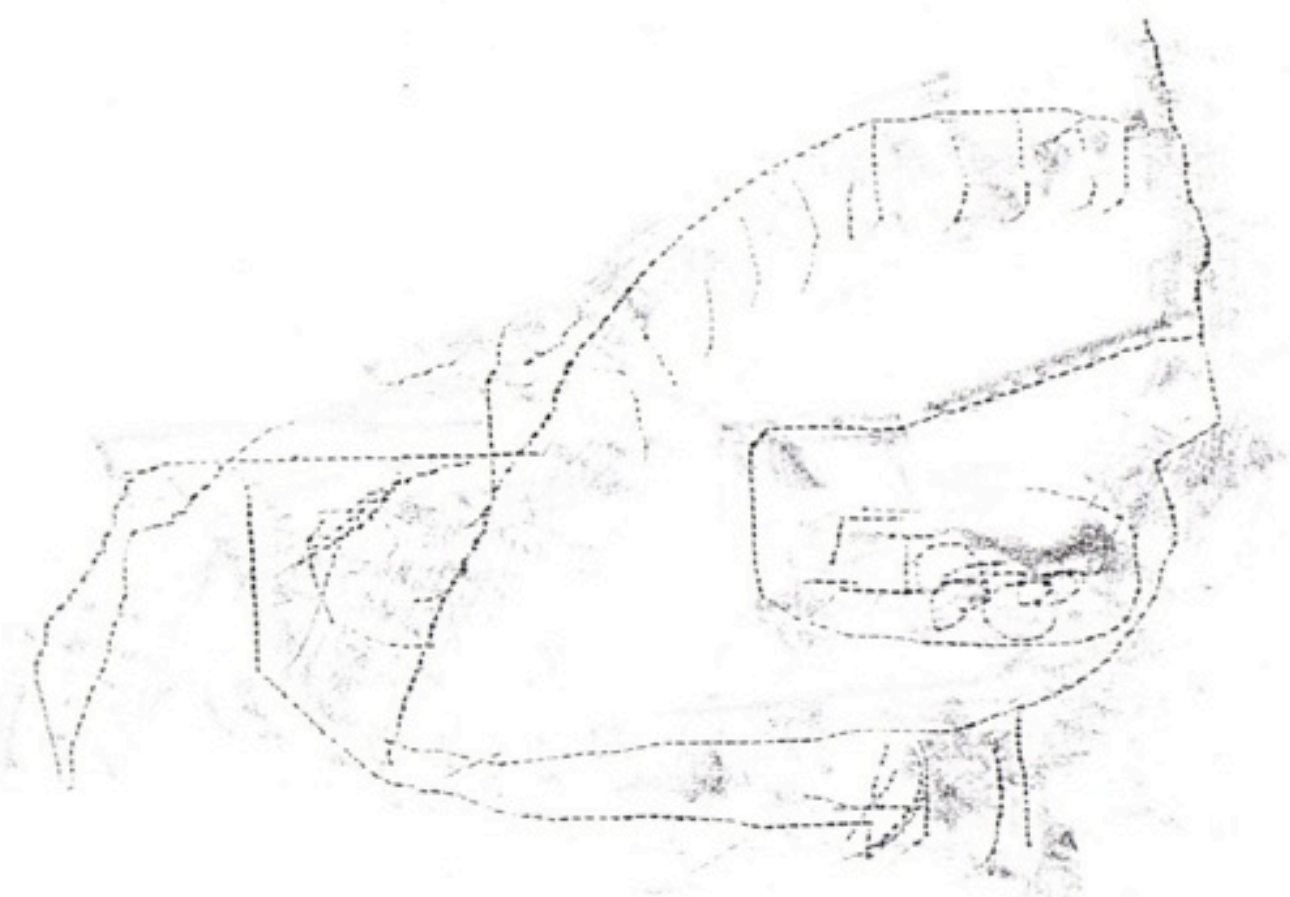


Prédio

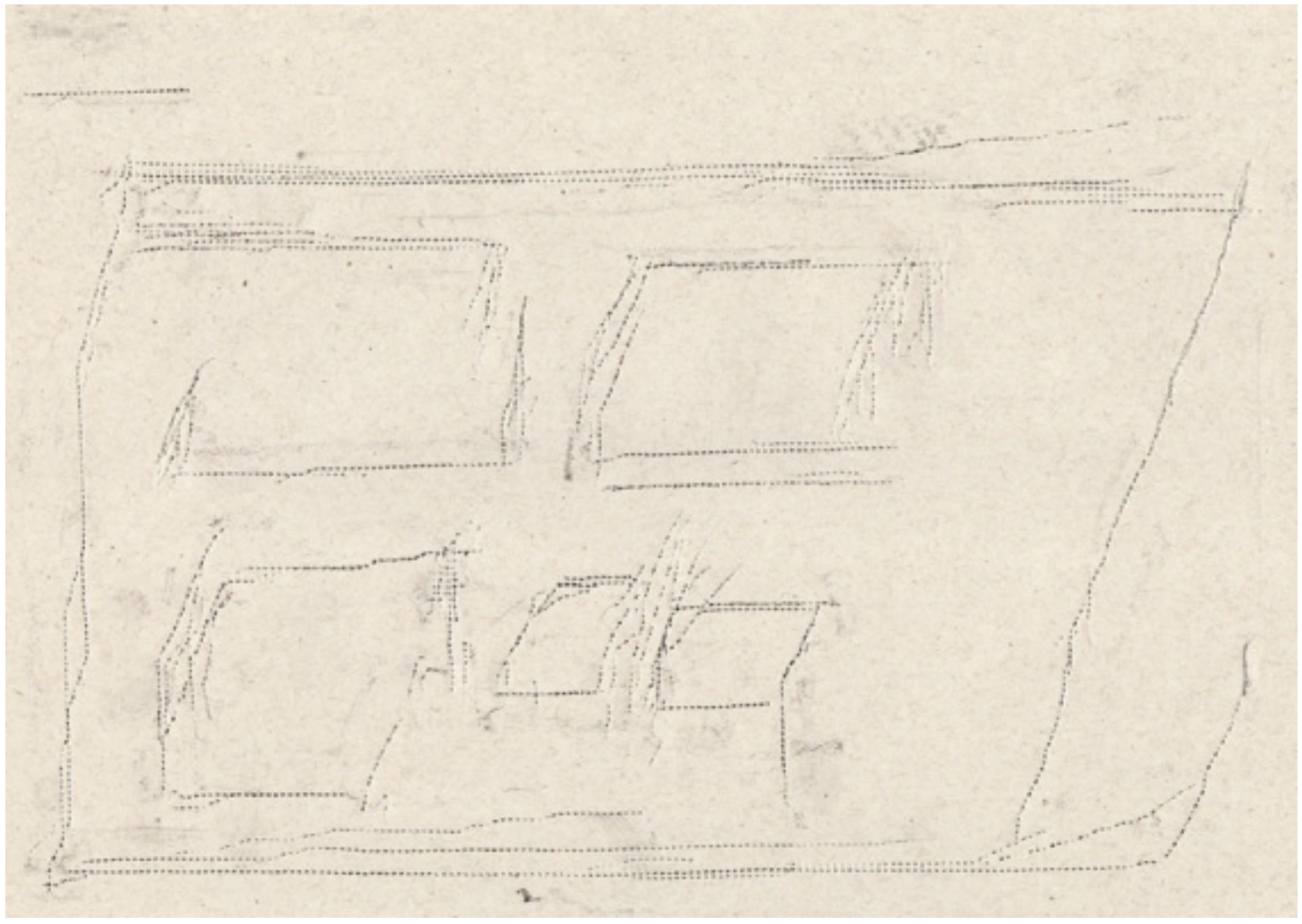

Leão

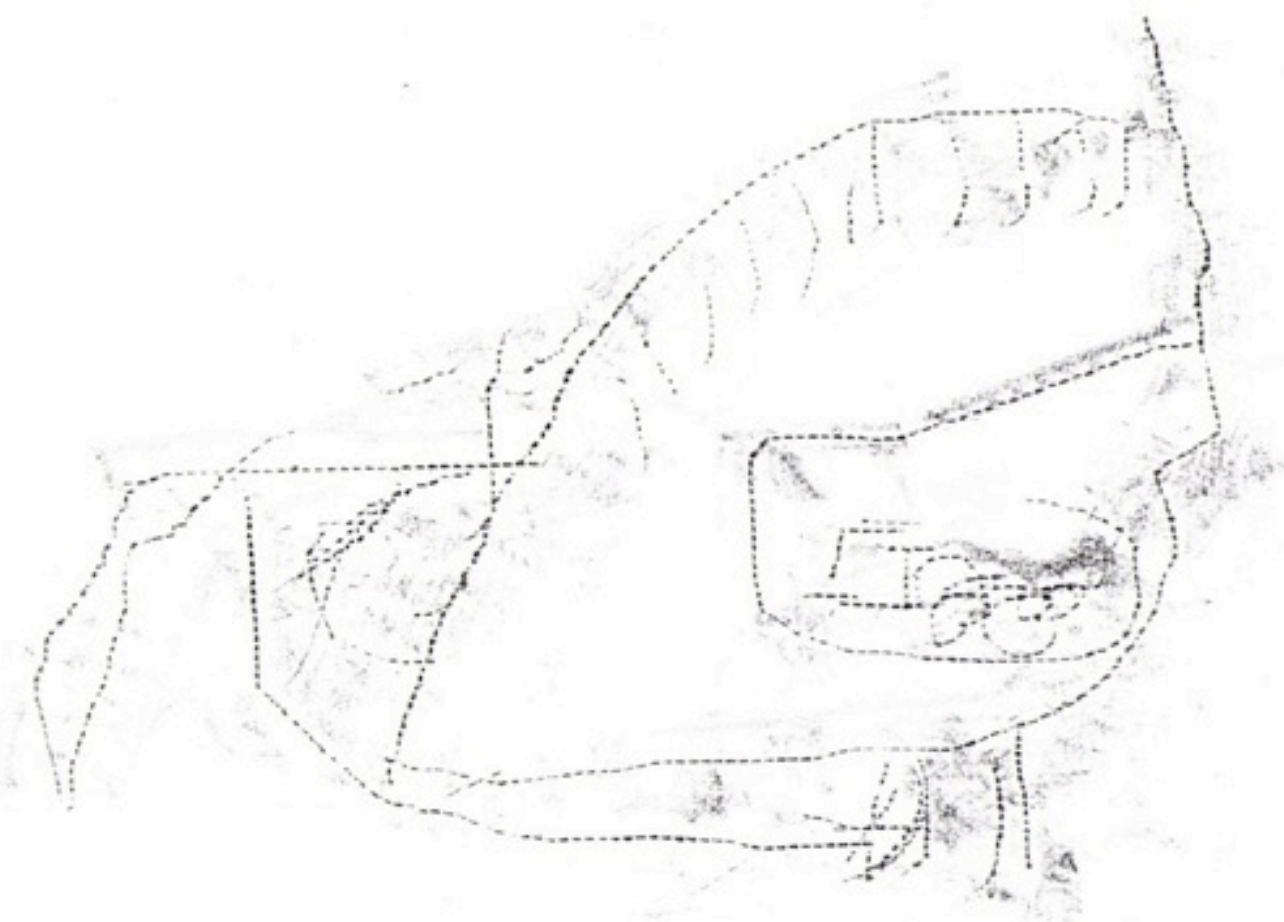


Prédio

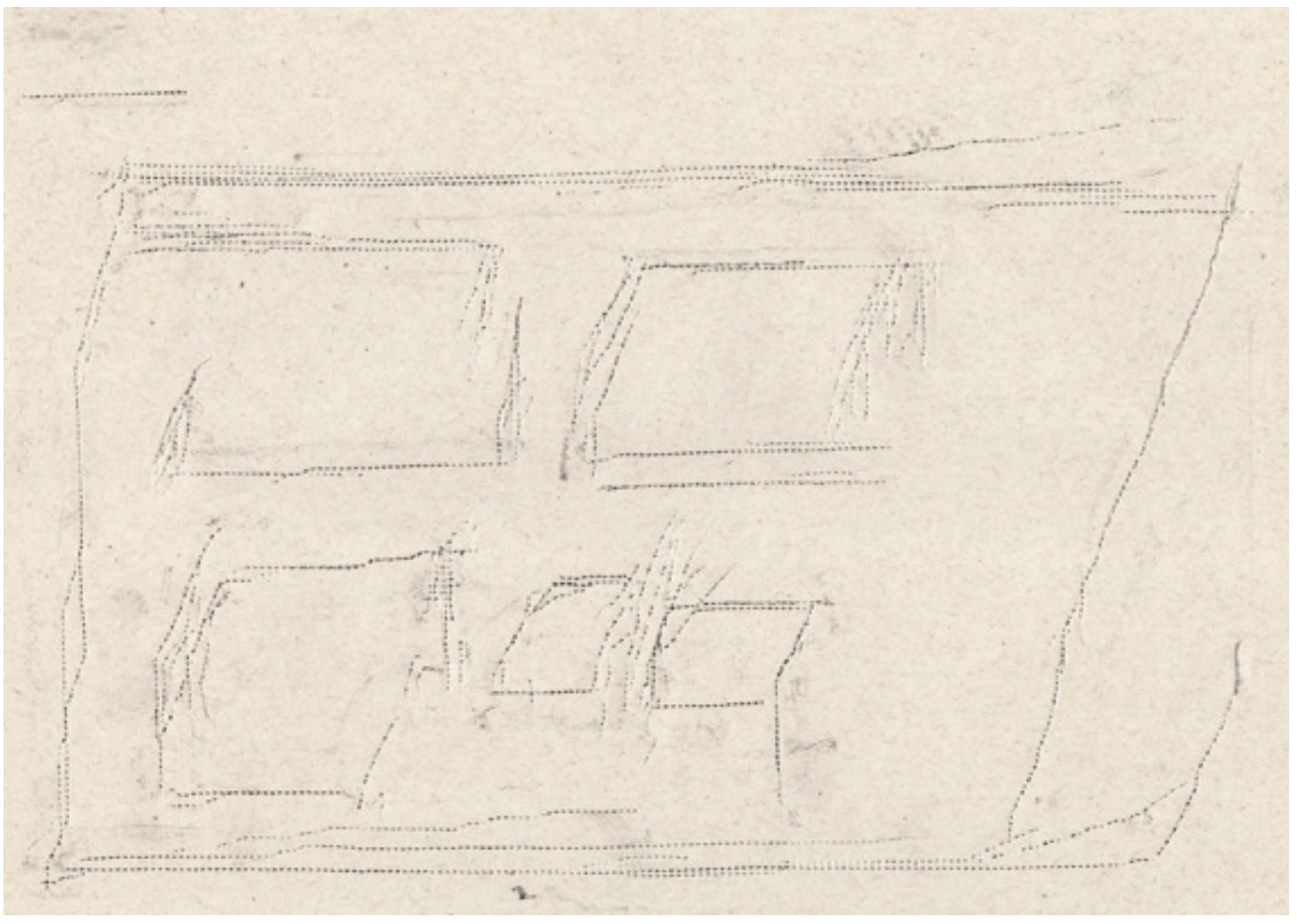

\section{Ilha}

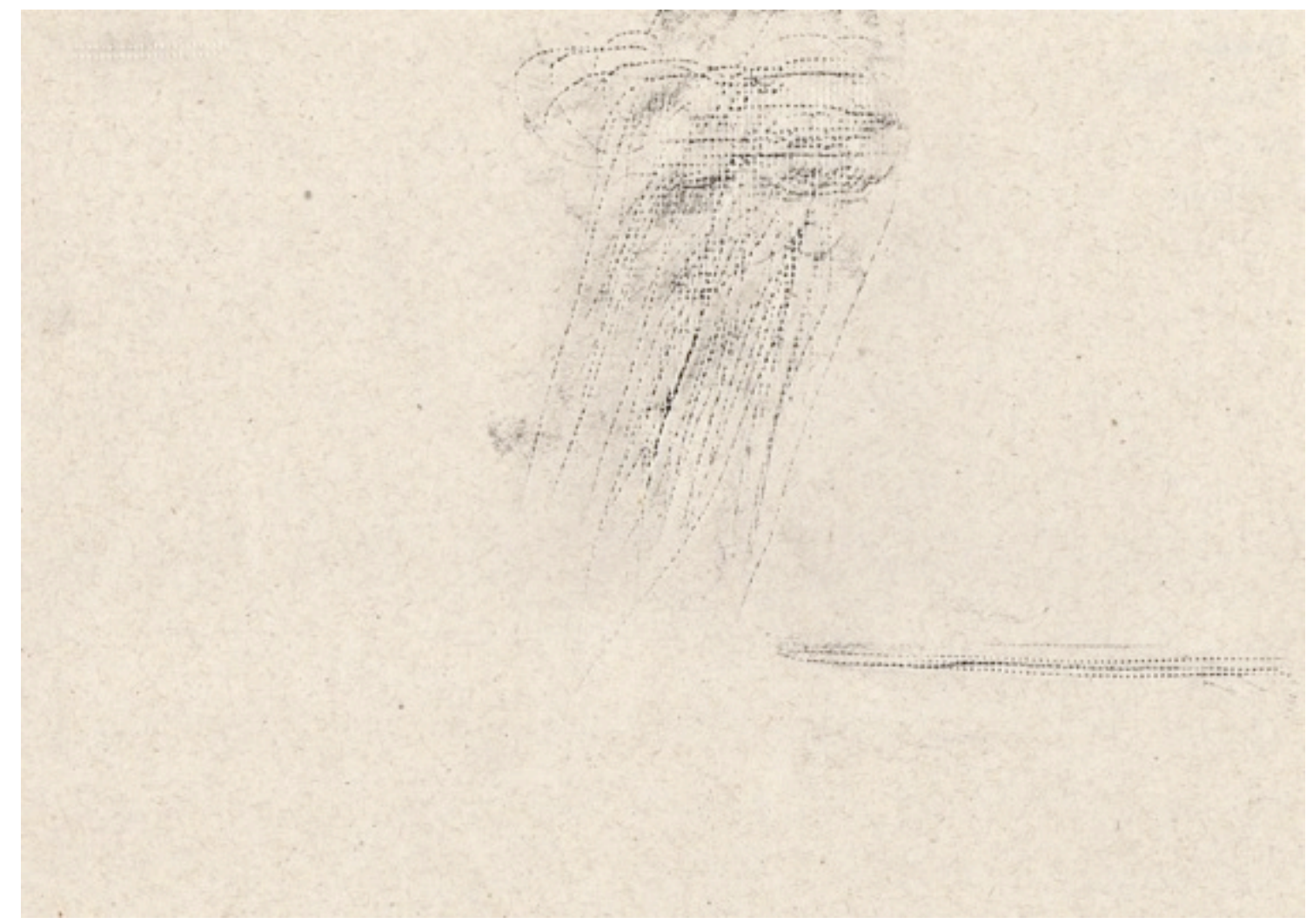




\section{Entrevista Pós-teste: Daniela}

E: Bom, então hoje eu vou te perguntar de novo sobre algumas coisas, tá? A gente já fez essa atividade, aí eu vou te perguntar sobre o que são algumas coisas, sobre o que você conhece a respeito dessas coisas e depois você desenha pra mim, tá bom?

D: Aham.

E: Então vamos lá. Daniela, você pode me dizer o que é uma girafa?

D: É um animal.

E: Que mais?

D: É um animal que vive na floresta.

E: Hum. Como que é esse animal?

D: Ela tem patas, atrás, e rabo e na frente é as patas do braço e o pescoço grande.

E: Tá, e o pescoço grande. Mais alguma coisa sobre a girafa?

D: Não.

E: Não? Então você desenha uma girafa pra mim?

D: Uhum.

E: Pode desenhar.

D. inicia o desenho.

D: Vou fazer dois olhos.

D: Amanhã eu vou trazer brinquedo. Minha professora de Educação Física falou que era pra trazer brinquedo.

E: Legal, o que que você vai trazer?

D: Vou trazer lápis de montar.

E: Será que você consegue montar uma girafa?

D: Não, não tem de montar girafa. Só tem de montar é, montar ônibus... Montar é...

E: Desculpa te interromper, J., que parte da girafa você tá fazendo agora?

D: O corpo.

E: O corpo?

D: É.

E: Que que você já fez?

D: Já fiz a cabe... A cabeça, fiz dois olhos.

E: Dois olhos. Tá ótimo.

E: Se você quiser virar a folha depois pra fazer os outros pode, tá?

D: Vou fazer as bolinhas que ela tem no corpo.

E: Que?

D: Os negócios que ela tem.

E: Os negócios que ela tem no corpo?

D: É, as bolinhas.

E: Ah.

D: São três, né?

E: Não sei, faz quantas você quiser.

D: continua desenhando.

D: Domingo meu pai vai votar lá em casa. Ele vai votar lá perto de casa aí quando ela vai ficar de folga. E a gente vai passear.

E: Pronto?

D: Ela vai ficar fazendo as coisas e eu vou passear.

E: Ela quem?

D: Minha mãe.

E: Deixa eu ver... Muito bem. Você pode me explicar como é que você fez? Isso aí é o que?

D: As patas. 
E: As patas, que mais?

D: Eu coloquei o rabo perto dos quatro. (ri) Aqui fiz quatro bolinhas, e aqui dois olhos dela.

E: Tá ótimo, obrigado. O outro, D. você pode me dizer o que é nuvem?

D: Nuvem, nuvem... A nuvem ela fica lá no céu. Ela a água, aí depois na chuva.

E: o que que acontece com a água?

D: Ela vira nuvem.

E: A água vira nuvem...

D: E ela vive lá do céu.

E: Que mais?

D: E... (pausa) É... (pausa) E... Deixa eu ver o que mais. E ela vive lá no céu.

E: Tá ótimo, e você sabe o tamanho dela, como que ela é?

D: Ela é pequena.

E: Pequena? Hum?

D: Pequena do tamanho de uma estrela.

E: Hum, entendi. Que forma que ela tem, você sabe?

D: Hum?

E: Que forma que ela tem?

D: Eu não sei.

E: Não? Então vamos tentar desenhar aqui?

D: Uhum.

E: Então vai, pode colocar a folha.

E: Você sabe desenhar a nuvem?

D: Sei.

E: Então desenha a nuvem.

D: Vamos ver se hoje eu faço uma bem maior. Bem maior!

E: Você vai fazer uma nuvem grande?

D: Uhum.

E: E aí, como é que ficou? Ficou bom?

D: Uhum.

E: Vamos pro outro?

D: Uhum.

E: D., você pode me dizer o que é montanha?

D: Montanha. Ela fica lá em cima. É, ela fica lá em cima.

E: Lá em cima da onde?

D: No alto, ela fica no alto.

E: Hum. E como é que ela é.

D: É... Ela tem uns banquinho dentro.

E: Tem banquinho dentro da montanha?

D: Tem.

E: Hum.

D: É... (pausa) E ela sobe.

E: Uhum. Mais alguma coisa? Sobe pra onde?

D: Sobe e fica lá no alto.

C: Uhum. Tá bom, vamos desenhar a montanha então?

D: Uhum.

E: Você quer que vire o papel assim, D, fica melhor? Pode desenhar uma montanha pra mim.

D: Posso fazer uma bem grande?

E: Pode, do jeito que você quiser.

D: inicia o desenho.

D: Olha o tamanho que vai ficar. Que nem uma montanha russa. 
E: Uhum.

D: Sobe, desce.

D. continua o desenho

E: Pronto? Explica pra mim como é que você fez aí? O que que é esse quadrado que você fez aqui?

D: A montanha.

C: É a montanha?

E: Tá certo. Próximo. D., você poderia me dizer o que é árvore?

D: Árvore...

E: Uhum.

D: É... (pausa) Árvore ela é uma planta.

E: Uma planta, que mais? Que tipo de planta? Como é essa planta?

D: É o tipo de planta que ela cresce e depois ela fica grandona.

E: E o que que tem na árvore?

D: As folhas.

E: Que mais? Tem mais alguma coisa?

D: Ela vive em cima dos pássaros.

E: Em cima do que? Patas?

D: Pássaros. Que os pássaros vivem em baixo das árvores.

E: Pássaros, entendi. Tem pássaros também. Tá bom, pode desenhar pra mim uma árvore?

D. inicia o desenho

E: Como é que você fez essa árvore aqui, D.?

D: Eu fiz ela ter esse coisinho embaixo.

E: Como é que chama esse coisinho embaixo?

D: É o... (pausa) O negócio que segura.

E: Uhum. E mais em cima que que você fez?

D: A árvore.

E: A árvore. E o que que são esses pontinhos que você fez aí?

D: Pontinho.

E: É, esses daqui. Aí mesmo onde você tá com o dedo. O que que é isso?

D: É tipo um nome.

E: Tipo o que?

D: Um nome.

E: Tipo um nome? Nome de quem?

D: Da árvore.

E: O que?

D: Da árvore.

E: Você escreveu árvore ou deu um nome pra ela?

D: Eu escrevi.

E: O que que você escreveu aí?

D: Árvore.

E: Entendi. Posso pegar? Vamos lá D., próximo. Você pode me dizer o que é um trem?

D: O trem fica na linha do trem, e ele (pausa). E tem rodas.

E: Uhum. Que mais?

D: Tem as portas.

E: Oi?

D: Tem as portas.

E: O que mais você sabe sobre o trem? Como ele é, pra que que ele serve?

D: Ele é grande, é grande, tem bastante janela

E: Uhum. 
D: Tem bastante banco.

E: Tá certo. Você pode desenhar pra mim?

D: Uhum.

D. inicia o desenho.

D: Tô fazendo as rodas. (pausa) Gritando. Parece que morreu alguém.

E: Por que?

D: Todo mundo gritando.

E: Gritando?

D: É!

E: Ah, você tá ouvindo gritos lá de fora, é isso?

D: É.

D. continua a desenhar.: A porta.

D: Olha o tamanho da porta que eu desenhei.

E: Ô louco.

D. ri

E: Você acha grande?

D: É. Ela é grandona.

E: Uma portona.

D: É que o trem é grande. Aí a porta é alta também.

E: Hum...

D: Você já andou de trem?

E: Eu já.

D: Eu também.

E: Pra onde você foi de trem?

D: É, a gente já passeou com uma vizinha, a gente já foi passear com uma vizinha nossa, que mora na casa de cima, e nós na casa de baixo, que tem um portãozinho pequenininho.

E: E onde vocês foram passear?

D: An?

E: Onde vocês foram passear?

D: (pausa) É, eu não me lembro o nome... É... Foi lá lá lá longe.

E: Lá onde?

D: Lá longe.

E: Longe?

D: É.

D. continua o desenho: Pode fazer mais uma porta?

E: Faz o que você quiser.

D. continua.

E: Quanta porta você fez hein?

D: É.

E: Tá ótimo. D. você poderia me dizer o que é leão?

D: Ah, um leão, leão fica no mesmo lugar que a, que a... A girafa vive.

E: Vive no mesmo lugar que a girafa?

D: É.

$\mathrm{E}:$ E como é que é o leão?

D: O leão não é tão grande, e nem tão médio.

E: Médio?

D: Não. Ele não é tão grande nem médio, ele é pequenininho.

E: Pequenininho?

D: É. Tem patinhas.

E: Oi? 
D: Tem patas e atrás tem um rabo, uma parte que é a perna e outra parte é os braços, e o pescoço dele não é igual o da girafa, o pescoço dele é pequenininho e ele tem uma tromba.

E: Tem o que?

D: Uma tromba. Uma tromba na frente.

E: Tem uma tromba na frente?

D: É.

E: Como que é essa tromba?

D: Parece num nariz, parece um nariz e é uma tromba. Parecendo um nariz.

D:Uhum.

E: Pera aí (mexe no papel). Pronto.

D. inicia o desenho.

D: Um negócio desses bicho, de girafa, leão. Eu já assisti passar na televisão. Já passou a girafa e o leão.

E: Já?

D: Já.

E: Que legal hein. Você aprendeu bastante sobre eles?

D: An?

E: Você aprendeu bastante coisa sobre eles?

D: É...

E: Esqueceu como é que desenha um leão?

D: É... Tem que fazer uma roda bem grande.

E: Uma roda?

D: É tipo, pra fazer, pra fazer... Que ele é dentro da roda né?

E: Ele o que?

D: (pausa) Ele fica dentro assim, da... Dentro dessa roda assim.

E: Hum... O que você vai fazer dentro dessa roda?

D: Ele.

E: Um leão? O leão fica dentro de uma roda, é isso?

D: É! Aqui na... Na vida real.

E: Na vida real?

D: Na vida real. Agora, (pausa) na vida normal, ele não é dentro da roda.

E: Não é dentro da roda?

D: Não.

E: Onde que é?

D: Ele é fora.

E: Ah.

D: A testinha porque os animais tem testa também né.

E: Que legal.

D: Animal testa também. Tem sobrancelhas.

E: É mesmo?

D: Tem, senão ia ficar parecendo feito um... Feito aquelas baratas feias.

E ri.

D: Ai ai ai, Deus me livre. Agora tô fazendo o nariz. Narizinho, narizinho.

E: É um nariz pequenininho?

D: An?

E: É um nariz pequenininho?

D: É um narizinho pequeno. Faz bem. Não é?

E: Oi?

D: Faz bem.

E: Faz bem? 
D: É. (pausa) Você já viu é... Galinha?

E: Galinha?

D: É.

E: Já.

D: Lá na onde a minha mãe foi criada tem.

E: É mesmo? Você já pegou galinha?

D: Ela já pegou. Ela já pegou o pintinho e quando ela ia pegar o pintinho a galinha foi pra cima dela.

E: A galinha ficou brava com ela?

D: Nossa, mama mia. Que eu não pegaria o bichinho não. Eu que não pegaria o filhotinho dela. Eu que não. Eu pegaria é, eu pegaria o milhos, porque eles comem milho. Aí eles comem milho, aí espalha tudo.

E: E agora, que parte do leão você vai fazer?

D: O corpo. Vou fazer aqui igual que eu fiz da outra vez.

$\mathrm{E}$ : O que que você tá fazendo agora?

D: O corpo dele assim, igual que eu fiz daquela vez.

E: Uhum. Como é que é o corpo do leão?

D: Ele é assim, parecendo... Parecendo (pausa) uma bolinha. Uma bolinha.

E: Uma bolinha?

D: Uma bolinha. Tipo uma bolinha, uma bolinha pros dentes dele.

E: Hum.

D: O pescoço. (ri)

E: Do que que você tá rindo?

D: De mim mesmo, eu sou uma boba. Esqueci do pescoço dele.

E: Esqueceu de fazer o que?

D: O pescoço dele.

E: Ah, o pescoço.

D: Pescocinho.

E: Você me explica aí esse leão? O que que é o que?

D: (pausa) Parece aqueles... É, leão-marinho.

E: Tá parecendo um leão-marinho?

D: É, leão marinho.

E: Tá legal. E o que que é o que, D.? Cadê olho, o nariz que você falou...

D: Aqui.

E: Esse é olho, e em cima do olho, o que você fez aí?

D: An?

E: Em cima do olho. E o nariz, cadê?

D: Aqui no meio. É no meio.

E: E essa parte de baixo o que que é?

D: Aqui é a boca.

E: É a boca, e o corpo que você falou que tava fazendo?

D: Aqui, aqui.

E: O corpo, que mais?

D: As patas aqui ó.

E As patas.

D: O rabo dele.

E: Eu só não entendi que que é esse circulo, D.

D: An?

E: O que que é esse círculo? Faz parte do leão ou é uma coisa que prende ele, você falou que ele fica dentro. 
D: É. Que prende ele.

E: Ah tá. Entendi. Tá bom. Vamos continuar então. D., você pode me dizer o que é prédio?

$\mathrm{D}$ : Ah, isso eu sei. Isso eu sei

E: Pode falar então.

D: Prédio é onde tem muitas casas onde tem muitas é... Janelas. Janelas com casas. Aí tem a porta, aí tem aquela jalelinha estreira.

E: Como é que é?

D: Tem aquela janelinha estreita, estreitinha. Assim, pequenininha.

E: O que que é estreitinha? Não entendi direito, desculpa.

D: Janelinha.

E: Janelinha?

D: Isso.

E: Uhum. E como é que é esse prédio? Que forma que ele tem?

D: Ele é assim, assim, quase igual do tamanho de um, de um negócio assim.

E: Hum.

D: Aí, aí, tem aqui (gesticula) aí tem aqui as janelinhas, aí tem a outra aqui, estreitinha assim aqui em baixo, aí tem a porta.

E: Tem o que embaixo que você falou? Tem a janela, embaixo tem o que?

D: Uma janelinha estreitinha. Aí aqui a porta.

E: Entendi, tá certo. Então vamos desenhar um prédio?

D: Aham.

E: Pode fazer. Pode desenhar o prédio.

D: Será que pode fazer mais grande, tudo bem?

E: Do jeito que você achar que fica bom.

D. inicia.

D: Hoje eu vim ouvindo música, hoje.

E: É mesmo?

D: É.

E: Que música que você tava ouvindo?

D: Sertanejo.

E: Sertanejo? Você gosta, né?

D: É. Você também gosta?

E: Gosto um pouquinho sim.

D: Eu gosto bastante. Música quatro.

E: Oi? Janelinha quatro, é isso?

D: É. Tô fazendo de lápis depois vou fazer. Pode fazer bastante?

E: Pode.

D: Vamo lá. Janelinha. Vou te passar aquela minha música, aquela música que eu gosto.

E: Qual?

D: Aquela... É... Ai é... Dê a mão e vem comigo.

E: Dê a mão e vem comigo?

D: É. Tem outra, é...

D: Tá chique.

E: Tá chique?

D: Tá.

D: Eu já tava passando no meu ex-colégio, tava todo mundo brincando e minha outra escola só pra atrapalhar.

E: É mesmo?

D: Agora eu vou fazer. Agora a porta. A outra porta.

E: Certo? 
D: Aham.

E: Muito bom, D. Vamos pro último. E: Você poderia me dizer o que é ilha?

D: ah, ilha é uma... Ela fica no mesmo que... Você sabe?

E: Não sei, você que tem que me dizer.

D: É... Fica tipo... Ela tem, ela tem parecendo...

E: Parecendo o que?

D: Parecendo uma sala.

E: D., eu não entendi muito bem o que você explicou. Você pode repetir o que é uma ilha?

D: A ilha... É... Como é que eu vou dizer. Tem banco.

E: Tem o quê?

D: Banco pra gente sentar. Uma outra escola que eu ia, não aqui, numa outra, aí tinha aí eu entrava, sentava lá, daí ia na roda-roda...

E: Do que que você tá falando?

D: Hã?

E: Do que que você tá falando?

D: Tô falando da... Aí tinha...

E: Que lugar é esse que você tá me descrevendo?

D: Hã?

E: Que lugar é esse que você tá me descrevendo?

D: Era uma... Era uma escola. Uma escola que eu tava, quando eu tinha seis e sete anos.

E: Entendi. E a ilha? Eu não tô entendo a ligação que isso tem com a ilha.

D: A ilha tinha também.

E: Tinha uma ilha na escola, é isso?

D: Uma ilha pra gente entrar, sentar e brincar. Aí eu entrava lá e ficava.

E: Entendi agora.

D: Aí depois, depois eu ia pra... Pra roda-roda. A gente senta e depois a gente roda. Fica rodando, fica rodando, até a gente ficar tonta. (ri)

E: Você pode desenhar essa ilha pra mim?

D: Aham.

E: Tó.

D. inicia o desenho.

D: Você já foi numa ilha?

E: Eu já. E você?

D: Eu já.

E: Como é que chamava a ilha que você foi?

D: Ilha da Índia. (ri) Ilha da Índia.

E: E como é que era essa ilha que você foi, D.?

D: Ah, era grande. Era grande...

E: Pronto?

D: Eu sou muito rápida.

E: Me explica aí o que tem nessa ilha?

D: Ilha. (pausa)

E: Que que você desenhou? Você pode me explicar, o que que é essa parte aqui...

D: A outra parte da ilha.

E: E esse risco que você fez no meio?

D: Aqui é o meio da ilha.

E: Tá legal, Daniela. Obrigado, viu? Por hoje é só. 
Desenhos Pós-teste: Daniela

Girafa

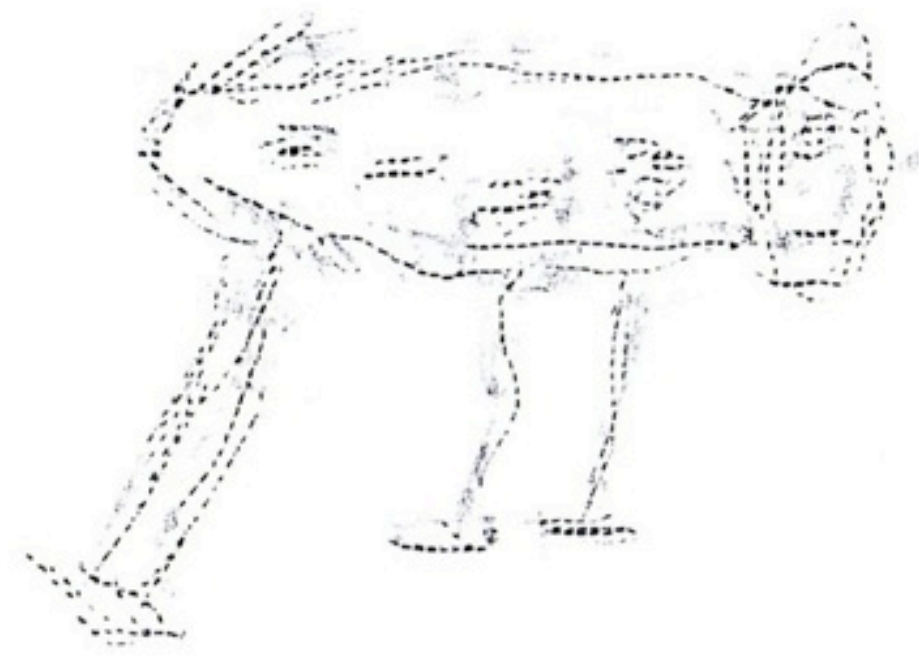

Nuvem

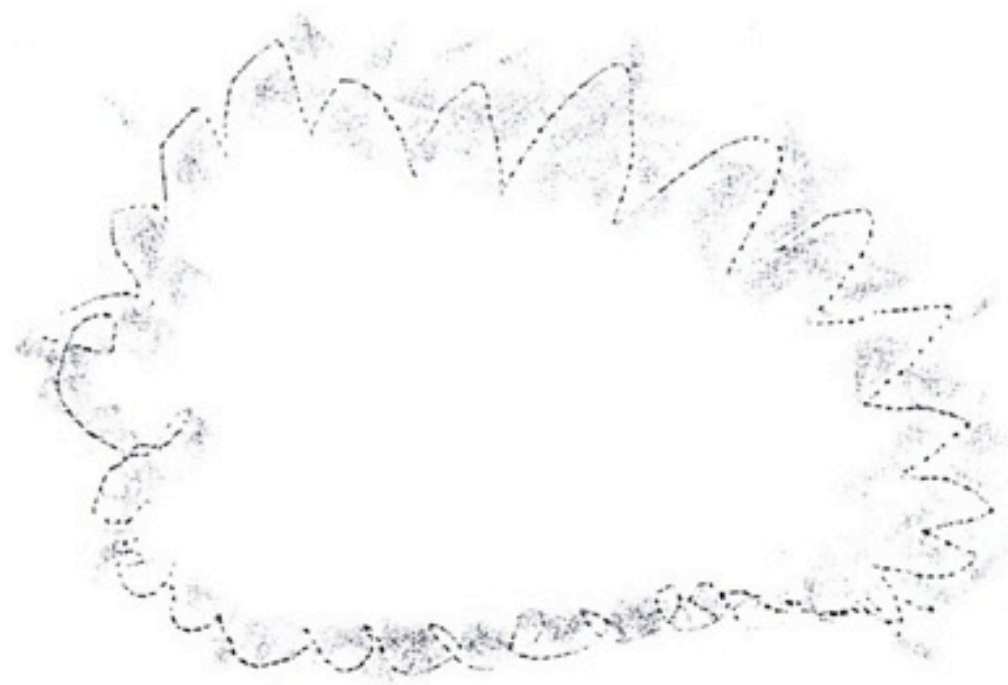




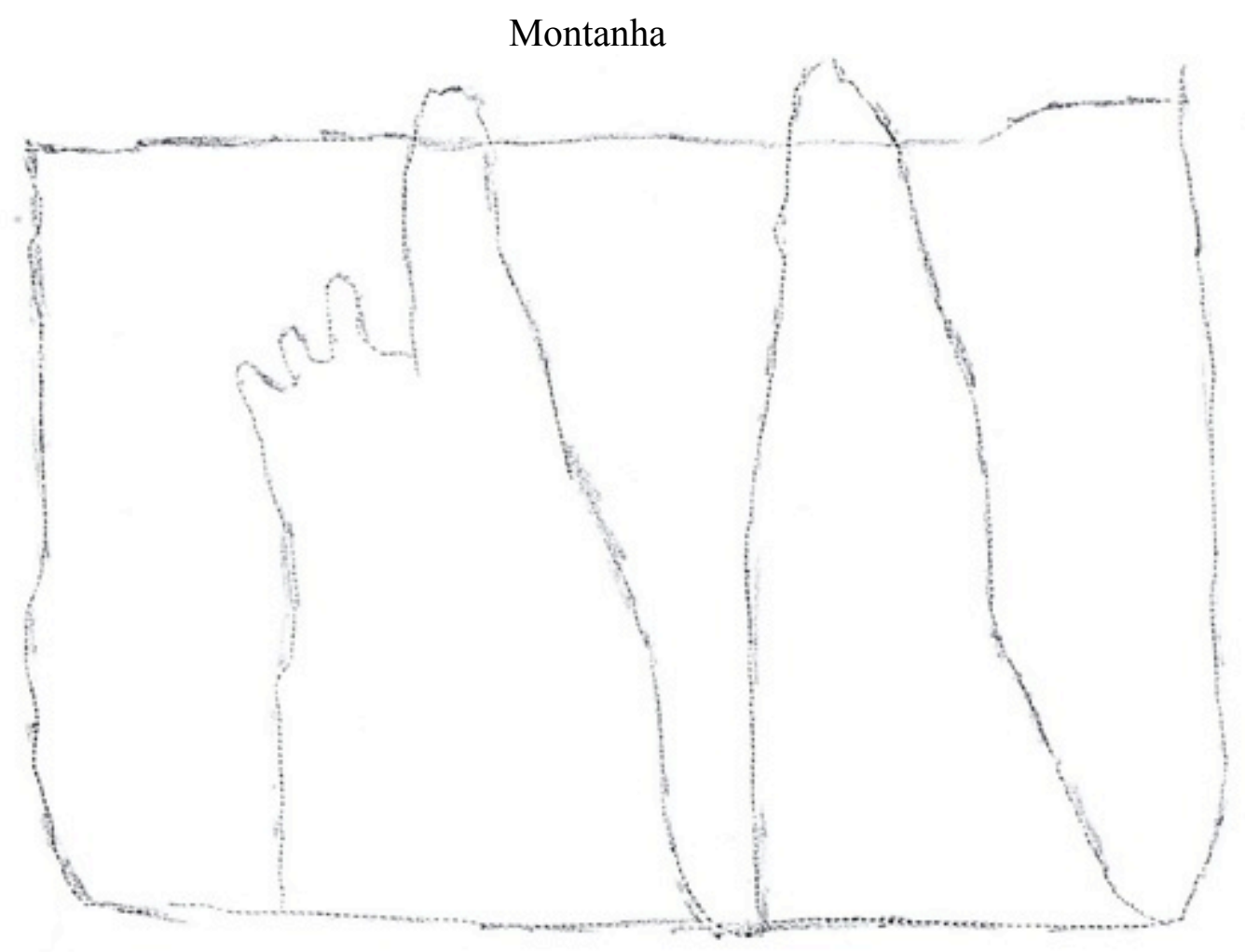

Árvore

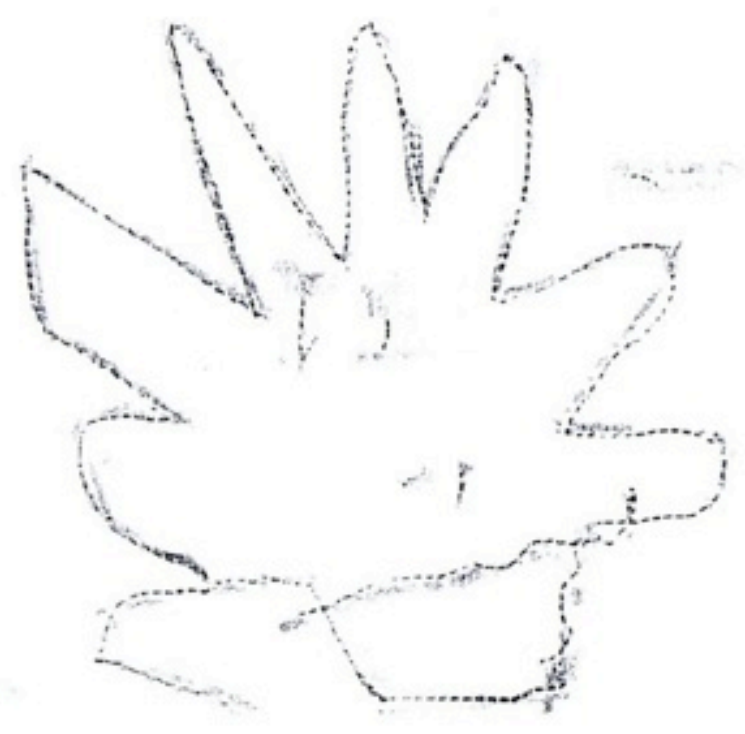


Trem

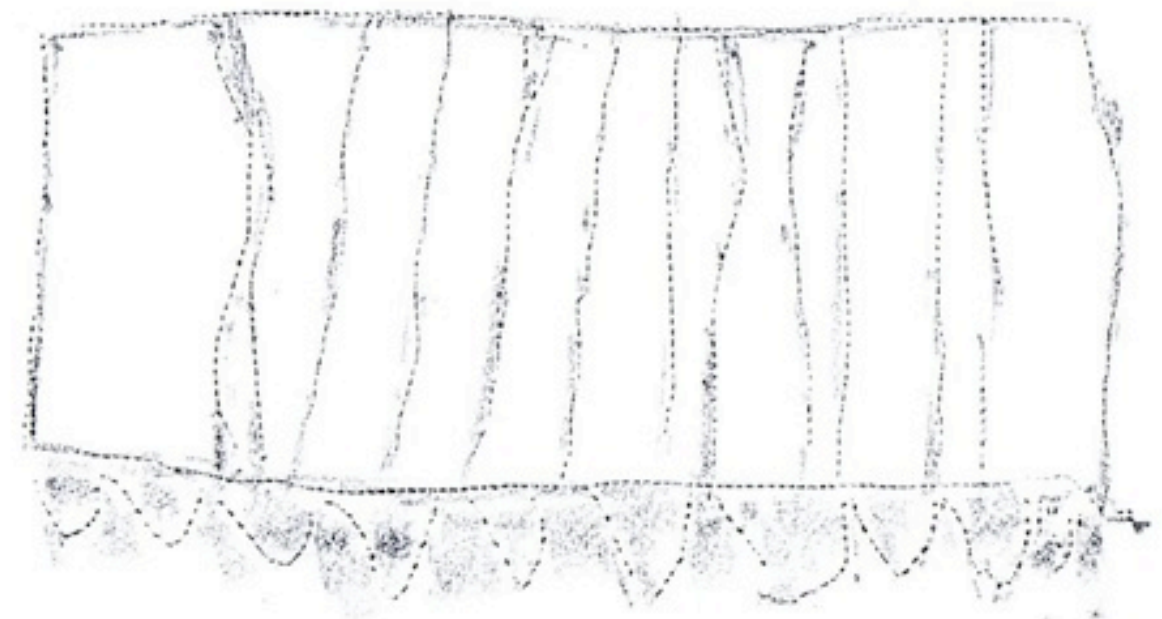

Leão

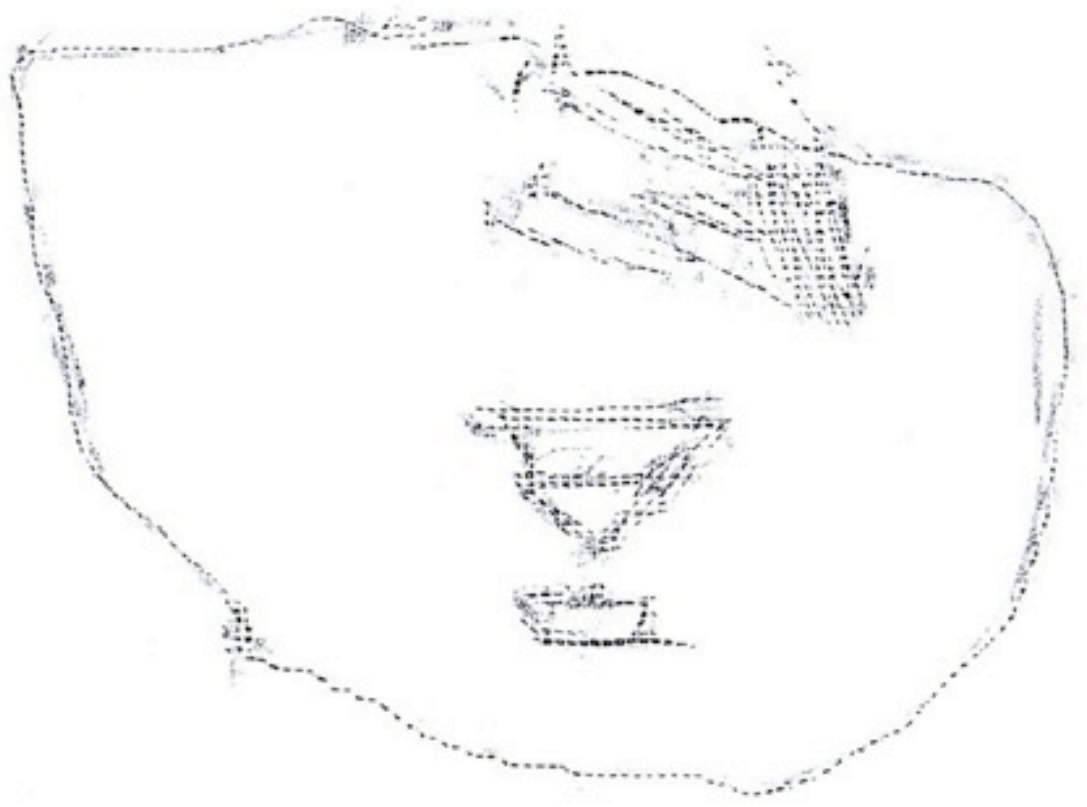


Prédio

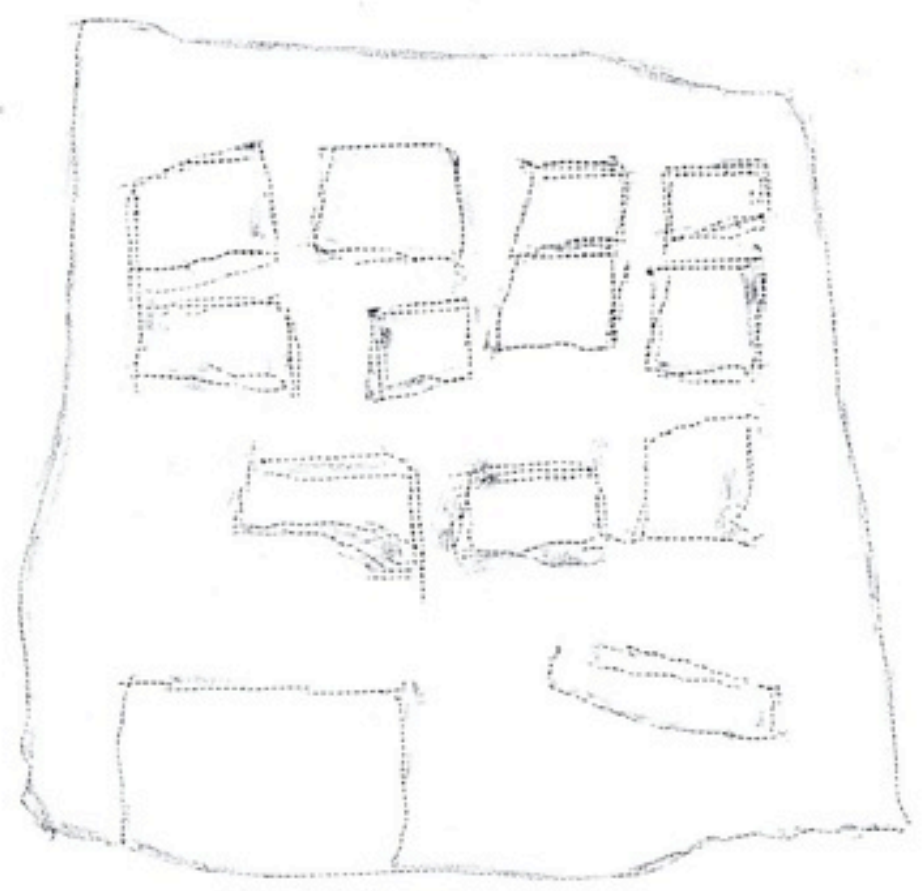

Ilha

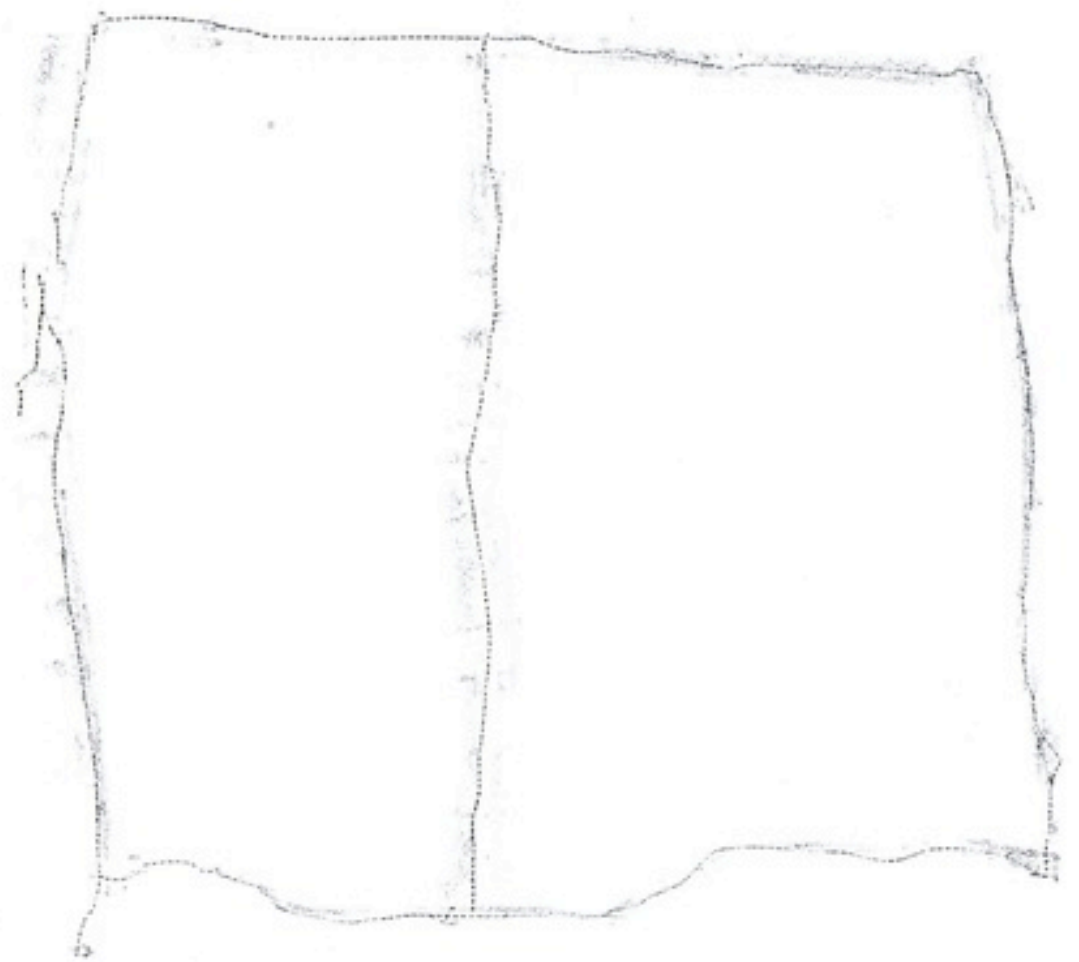




\section{Entrevista Pré-teste: Rogério}

E: Você poderia me dizer o que é uma girafa?

R: Uma girafa, ela é assim e tem o pescoço comprido

E: Assim como?

R: Ela é alta e tem o pescoço comprido

E: Ela é alta e tem o pescoço comprido, mais alguma coisa que você sabe sobre a girafa?

R: Não.

E: Não? Onde que ficam as girafas hein?

R: No zoológico.

E: No zoológico! Já foi?

R: Já, uma vez.

E: É mesmo? Te mostraram as girafas?

R: Não!

E: Não?

R: Não!

E: Puxa vida, então tá bom. Próxima, vamos lá, L. o que é uma nuvem?

R: No céu, uma nuvem é assim branca.

E: Hum.

R: E fica no céu a noite, a noite e de dia.

E: A noite e de dia? Pode me falar uma coisa que parece uma nuvem?

R: Ela é assim (gesticula) e é pintada toda de branca

E: Legal, próxima. Você pode me dizer o que é uma montanha?

R: De pedra.

E: De pedra? Mas como que ela é?

R: Ela é quadrada e tem um monte de pedra

E: Ela é quadrada e tem um monte de pedra? Já viu uma montanha?

R: Não

E: Já foi numa montanha?

R: Tem um morro alto lá na pracinha né, ele é grande e ele é de barro. Barro e mato.

E: E uma montanha é grande também?

R: É.

E: É? Maior que esse morrinho ou menor?

R: O Morro ele é assim, dali até aqui. (gesticula)

E: Você consegue subir?

R: Consigo.

E: Tá bom. Vamos La, próximo. Você pode me dizer o que é uma árvore?

R: De madeira e tem folha em cima

E: Você mora em casa?

(R faz que sim com a cabeça)

E: Tem árvore lá?

R: Não.

E: E aqui na escola?

R: Tem.

$\mathrm{E}:$ Tem?

R: Tem.

E: E as árvores? Elas são grandes, são pequenas, como elas são?

R: A de lá da pracinha tem uma grande e ela é alta

E: Legal, muito bem. Próximo, você poderia me dizer o que é trem?

R: Vagão. 
E: Explica um pouco melhor, como assim?

R: É, ele é de ferro tem vidro e rodas.

$\mathrm{E}$ : E pra que que serve?

$\mathrm{R}$ : Pra andar, pra andar, pra andar no trilhos

E: Nos trilhos? Você já andou de trem?

R: Já.

E: Já? Gostou?

R: Gostei

E: Legal. Vamos lá para a próxima. R., você poderia me dizer o que é leão?

R: Dentes pontudos, rabo comprido e patas e unhas

E: Onde é que fica o leão?

R: No zoológico.

E: No zoológico? Esse você foi ver?

$\mathrm{R}$ : Esse daí eu fui, um pouquinho só

E: Como que ele é?

R: É assim (gesticula) tem quatro patas aqui e tem um fucinho tipo de cachorro.

E: Tipo de cachorro? Ele parece com um cachorro?

$R$ faz que sim com a cabeça

$\mathrm{E}: \mathrm{O}$ que ele tem de diferente do cachorro?

R: Orelha?

E: Cachorro não tem orelha e leão tem? É isso?

R: Tem, tem, cachorro tem. É a cor dele.

E: Cor? Qual é a cor do leão?

R: Tem alguns que é laranja, e tem marrom.

E: Muito bem, beleza. Vamos para a próxima. Poderia me dizer o que é prédio?

R: Tem vidros e andares e janelas

E: Pra que que serve o prédio?

R: Para subir e trabalhar.

E: Trabalhar? Você conhece alguém que trabalha em prédio?

$\mathrm{R}$ : faz que não com a cabeça

E: Não? E vc já visitou algum prédio? Nunca subiu num prédio?

$\mathrm{R}$ faz que não com a cabeça

$\mathrm{R}$ : O das clinicas tem um andar só.

E: Um prédio tem mais de um andar?

R: Do das clinicas tem vários, mas só que eu vou no segundo por causa que é só um só.

E: Entendi. Mas é um prédio ou não o hospital das clinicas?

R: É.

E: É? Então você já foi num prédio?

R: Várias vezes, eu sempre fui. Mas eu vou até o quarto andar.

E: Como você vai até o quarto andar?

R: De elevador

E: De elevador? Todo prédio tem elevador?

R: Tem um monte de elevador

E: Beleza, o último R. Poderia me dizer o que é ilha?

$\mathrm{R}$ : Uma ilha cheia de mutantes que nem a da novela. Acertei?

E: Uma ilha? Como é essa ilha?

R: Tem bichos e tem pessoas.

E: Que ilha é essa que você conhece? Você falou dos mutantes, uma coisa assim, me conta direito essa historia.

$\mathrm{R}$ : É que nem os mutantes da novela 
E: Hum

R: Então, tem bichos e tem pessoas que é assim

E: É uma ilha que tem mutantes? É isso? É uma novela você falou?

R: É. Tem uma doutora, ela faz experiências com crianças, a crianças recém nascidas.

E: Entendi! Muito bem R, então tá bom! Primeira parte acabou, vamos para a próxima! Vou te mostrar alguns desenhos agora, e você tenta decifrar o que é, tá bom? Então esse desenhos tem a ver com as coisas que eu te perguntei, tá? São exemplos das coisas que eu te perguntei! Poe a mão... Vê se você consegue identificar o que é esse desenho ai, dá pra sentir?

$\mathrm{R}$ toca: Eu não consigo sentir direitinho.

E: Não? Deixa eu reforçar para você!

$\mathrm{R}$ : Se tivesse formas diferentes eu não consigo ler assim de linhas

E: Tá. Deixa eu refazer. Posso pegar? Eu vou refazer e você vê se melhora, tá bom?

Entrevistador reforça o desenho

R: A lápis, E., eu não consigo ver direito com as mãos.

E: Não tá desenhado, tá?

R: Tá só com o contorno?

E: Ta só com o contorno.

R: Em cima né? Esse ai parece um carro

E: Você acha que parece um carro? Por que?

$\mathrm{R}$ : Por causa da textura

E: Como é essa textura?

R: ele é assim, assim, assim (gesticula) e ele tem duas janelas, tem rodas, ele é tipo um quadrado, ele é um quadrado.

E: Hum

R: E tem os vidros na traseira, dos lado e da frente

E: Você já vai me mostrar tudo isso aí no desenho

R espreguiça

E: Oh, dá uma olhadinha, melhorou?

R toca: Um pouco.

E: O que que é isso ai? É uma das coisas que eu te perguntei.

R: Um prédio?

E: Muito bem, por que você acha que é um prédio?

R: Por causa da janela e do coisinho aí em cima.

E: O que é esse coisinho aí em cima?

R: Uma janelinha pequena.

E: Muito bem, isso ai, é um prédio.

$\mathrm{R}$ : E tem uma porta gigante aqui.

E: É, essa é a porta. Isso ae, legal, ótimo! Vamos ver o próximo! Que tá em relevo também!

$\mathrm{R}$ : Eu fui dormir advinha que horas?

E: Que horas você foi dormir?

R: 12 e 4, meia noite e quatro! Por causa do jogo do Corinthians!

E: Quem ganhou?

R: Empatou. E o fluminense ganhou 3x1.

E: Puxa, então vamos lá.

R: O São Paulo ganhou de 2x0 do flamengo.

E: Oh... Dá uma olhadinha nesse desenho aqui, e vê o que ele pode ser.

R: Um leão?

E: Por que você acha que é um leão?

R: Por causa do negocinho aqui

E: Descreve pra mim esse leão. 
R: Ah esqueci, é o trem.

E: Por que?

R: Por causa que tem um negocio em cima, faz barulho e tem pregos

E: Muito bem, perfeito. Isso ae!

R: E tem um negocio aqui assim de viradinhas.

E: Como é que você sabe que o trem tem isso?

$\mathrm{R}$ : Porque aqui em baixo tem uma ponta, aí ele vira assim e faz assim. Aí tem um negócio aqui.

E: Pra que que serve esse negocio aí?

R: Esse negócio aqui, pra parar o trem é esse daqui, e pro trem fazer barulho é aqui.

E: Legal, gostei!

R: Aí o trem anda muito rápido.

E: Bom, vou te mostrar o último tá?

$\mathrm{R}$ toca: Deixa eu ver, isso daqui é uma girafa?

E: Por que que você acha que é uma girafa?

R: Por causa que o pescoço e linhas.

E: Linhas?

R: Tem duas linhas, uma em baixo e uma em cima

E: Olha, vou te falar que parece uma girafa mesmo, mas não é uma girafa!

R: Não é uma girafa?

E: Isso que você tocou em cima tá vendo, isso aqui, é uma árvore ta vendo, ó o tronco. E mais pra cima você vai sentir as folhas.

R: Aqui.

E: Isso, só que essa árvore ela tá em um lugar, Poe a mão em baixo, aí, o que é isso ai?

R: Um vaso?

E: Parece um circulo né, então, isso é uma ilha, e essa linha que você tá tocando, é a linha do mar. A ilha é um pedaço de terra que fica no mar, tem água em todos os lados dela.

$\mathrm{R}:$ Aqui?

E: É, isso seria a água.

R: Tá pintado né?

E: Não, não tá pintado não. Aliás a folha tá vazia, só ta com relevo, tá? Beleza?

$\mathrm{L}$ faz que sim com a cabeça

E: Então tá bom, esse a gente vai falar de novo depois. Bom, muito bem, agora vou te pedir para fazer o seguinte L, vou pedir para você desenhar primeiro um prédio e depois um trem, pode ser?

R: Pode, se eu conseguir fazer né? Por causa que eu não sou muito bom em pintura.

E: Não tem problema nenhum, a idéia não é fazer uma obra de arte não, ta? Eu quero só ver como você desenha.

R: Se borrar né?

E: Fica livre, então você vai usar o desenhador, já te mostrei esse desenhador já né? Ele faz os desenhos de relevo, deixa eu pegar um papel aqui.

R: Isso daqui é tipo uma prancheta, só que não é.

E: Exatamente. Como uma prancheta de desenho.

$\mathrm{R}$ : Ele aperta aqui para sair a folha.

E: Isso, pode apertar, aperta e gira do seu lado direito, lado esquerdo, desculpa! Puxa pro lado esquerdo. Isso, deixa eu só pegar uma folha de papel aqui.

R: Se fecha essa parte, essa parte vai junto né, E.?

E: Vai. Ela prende a folha! Abre ai pra mim, pra eu colocar a folha para você! Levanta o braço um pouquinho. Pode fechar! Ótimo, isso! Oh, vou te dar um lápis que ele tem uma 
ponta, ele é pontudo pra marcar o papel tá? Ela não solta tinta! Pode começar. Faz primeiro o prédio pra mim. Se precisar te dou outra folha, não fica preocupado

Rogério começa a desenhar

R: Aí tem os andares que tão em reforma, aqui tem uma porta.

(pausa)

E: O que é esse negocinho ae?

$\mathrm{R}$ : Esse aqui?

E: É.

R: É o coiso de segurar aqui em cima.

E: Segurar? Segurar o que?

R: Quando a pessoa vai se balançar aqui!

E: Se balançar? Como assim?

R: Assim, que nem aqueles trampolim, trampolim não, que anda assim de um lado pro outro?

E: Balanço?

R: É.

$\mathrm{E}: \mathrm{Ah}$, tem um balanço no seu prédio. É isso?

R: Tem.

E: E esse círculo que você fez mais embaixo ai?

R: Aqui?

E: É?

R: Esse daqui é uma parte do elevador.

E: Tá.

R: Entra na portaria, tem elevador para subir.

E: Ah entendi, então ai onde você tá com o dedo é a portaria...

R: É. E aqui é o elevador dentro.

E: O elevador? Tá. Muito bem, tá ótimo!

E: Vira a folha para você. Pra você ver como ficou.

R. toca: Ficou parecendo um boneco.

E: Ficou parecido com um boneco?

R: Uhum.

E: Mas é um prédio?

R: É!

$\mathrm{R}$ : Eu não encostei aqui também, nessa parte aqui.

E: Deixa eu ver.

R: Nessa parte aqui.

E: Ah..é verdade.

R: Aí, aqui só falta o negocinho daqui.

E: Você quer por?

R: Não, deixa assim mesmo.

E: Tá bom, deixa eu escrever seu nome aqui.

R: Você escreve meu nome em relevo?

E: Oi?

R: Você escreve o nome das pessoas em relevo?

E: Eu escrevo a tinta, eu não tenho deficiência visual, esqueci de te falar, então eu faço à tinta as coisas. Poe essa folha aí pra mim?

R: Esse negocinho daqui é o que?

E: Isso é material pra usar, tipo carretilhazina. Prende a folha.

R. Entendi pra que que serve esse negocinho aqui ó.

E: Isso é uma reglete, que você tá na mão.

$\mathrm{R}$ : E essa parte daqui? 
E: Isso é pra usar como compasso. A caneta, você faz pra mim o trem?

R: Faço. Não sei, assim.

E: Ah, faz do seu jeito, não se preocupa.

R. inicia o desenho.

R: Não posso errar. (pausa) Essa aqui eu não encosto muito bem, direitinho.

E: Tudo bem, sem problema, a gente vai treinar isso depois. Me mostra as partes do trem? Vira o papel aí pra você me mostrar melhor.

R: Assim?

E: Só vira aqui pra não ficar de ponta cabeça. Mostra pra mim as partes do trem.

R: Ele é assim. Eu comecei por aqui, não foi?

E: Então aqui é a frente né? Deixa eu marcar aqui.

R: Você marca aqui?

E: Fiz aqui, a frente. Não dá pra sentir, né? Escrevi com a caneta. Hum.

R: E aqui, é uma janelinha.

E: Uma janelinha...

R: Pra deficientes, né? E aqui é reto, aqui eu viro, aqui eu não coloquei direitinho o trilho. Assim, aqui, aí vira e faz as rodas.

E: Legal, aqui são as rodas, né? Tá ótimo.

$\mathrm{R}$ : E essa reglete aqui?

E: Pode virar pra você ver.

$\mathrm{R}$ : Ah, entendi como é que é? É de pontos grandes, não é que nem a nossa. A nossa tem pontinhos pequenos.

E: É mesmo?

R: E essas daqui não, tem vários pontos grandes. E essas daqui dá pras pessoas deficiente sentir bem melhor.

E: Hum, que legal. Então, R., você quer tentar desenhar a ilha? Você lembra como é?

R: Queria.

E: Então vamos lá.

R: Tem que abaixar as duas partes ao mesmo tempo, E.?

E: Da reglete? Você coloca a folha entre uma e outra, não é? Você escreve com a reglete?

R: Não.

E: Não. Você usa só a máquina, né?

R: A máquina eu uso pra fazer lição, não dá pra fazer desenho na máquina.

E: Ah, é pra escrever. Não, mas a reglete também, é só pra escrever. Tó, a caneta, pode fazer aí.

R: Ixi, deixa eu ver.

E: Faz tranquilo, sem preocupação.

R: Aqui, sabe de quem que era essa casa? De uma pessoa. Era da Dra. Julia, dos mutante. Aí ela saiu daí, ela foi criando os mutante, né? Aí, teve duas pessoa que era do mal, o Metamorfo que é invisível, que ele fica invisível, e o Vlado, que ele é vampiro.

E: Hum.

R: Aí a Dra. Julia foi fazer uma experiências.

E: Que tipo de experiência?

$\mathrm{R}$ : Experiências com gêneres de humano e de coisas assim, pra fazer bichos.

E: Nossa.

R: Aí teve uma mãe que falou que ela é louca, por causa que o bebê dela tinha que nascer normal aí nasceu de luz.

E: Como assim nasceu de luz?

R: Assim, luz. Tipo bebê de luz.

E: Sei. 
R: Aí aqui tem o laboratório da Dra. Julia um pouquinho mais pra frente.

E: Pode fazer se você quiser.

R: Aí tem dinossauro, tem sapo bufo, sabe como é que ele é? O sapo bufo ele aumenta, ele

fica cada vez mais gigante.

E: É mesmo?

R: Aí ele tem um veneno muito forte, que mata muito rápido.

E: Ô louco.

R: Então...

E: Nessa ilha tem tudo isso aí?

R: Tem. Tem até um gigante na ilha.

E: Nossa.

(pausa)

R: Aí aqui eu vou fazer um negócio aqui assim, que é coisa de mar, não é? Essa parte daqui de cima. E aí aqui eu vou tentar fazer um barco. (pausa) Quer dizer um mar não. Por causa que tem um pescador, a mulher dele foi pega pelo Vlado, a mulher do pescador. E o pescador, sabe os bandido da novela? Eles queria matar ele, por causa que a mulher dele descobriu a clínica da pro gênese da Julia.

E: Essa Julia ela é...

R: Tem cabelo longo

E: ...Bandida?

R: Não.

E: Ela é do bem.

R: É. Ela é uma médica que ela é presa também, ela quase morre de helicóptero. O helicóptero caiu no meio do mar aí ela foi até a ilha. Aí ela arrumou as... Como é que anda debaixo da água?

E: Submarino.

R: É, lá tem um monte de submarino debaixo da água. Aí ela pega e sai da ilha de novo. Aí fica um monte de mutante lá na ilha.

E: Interessante.

R: Aí tem dois que quer sair da ilha. O Vlado e o Metamorfo.

E: Isso ai que você ta desenhando o que é agora?

$\mathrm{R}$ : Tô desenhando uma coisinha.

E: Que coisinha é essa?

R: Uma metade de um corpo. Adivinha quem eu tô desenhando?

E: Não sei.

R: Uma seria.

E: Uma sereia?

R: Ela... O Cris... Conhece o Cris da novela?

E: Não, não vejo essa novela, eu nunca vi essa novela.

R: Essa novela é a novela das 6 da tarde. Vai até sete horas eu acho, sete horas não, menos do que isso.

E: Muito bem, pode tirar a folha.

R: Aí né, tem um menino que cresce rápido, e ele, a Dra. Julia quer fazer experiências com ele na ilha, e ele não quer ir pra ilha, ele cata e começa a fazer levitar as coisas.

E: Nossa.

R: Esse menino sim é o Cris. Aí a Iara, que é a seria, ela quer namorar com ele.

E: Ela quer namorar com o Cris?

R: É, da ilha.

E: Então deixa eu marcar aqui quem é quem. 
R: Que ele vai pra ilha com a Julia, que é uma menina que o nome dela é Tati, ela, quando ela tá irritada assim, ela faz levitar e quebrar as coisas.

E: Nossa, que poder, hein? Podemos fazer a árvore.

R: Vai lá.

R: Você tem que assistir essa novela. É muito da hora. Que novela você assiste?

E: Não assisto porque tô trabalhando nesse horário.

R: Que pena. Toma.

E: Vamos fazer o leão?

R: Tudo bem. Coloca a folha assim né? O reglete prá lá?

E: Isso, assim fica melhor.

R: Vou fazer esse lado aqui.

R: Daqui a pouco vai ter leão na ilha dos mutantes também.

R: Ficou pronto. Deixa eu fazer a girafa.

E: Toma

R: Esse traço prá ca, agora aqui.

R: Pronto, qual falta?

E: Nuvem e montanha.

$\mathrm{R}$ : Pode fazer a montanha?

E: Claro, a folha aqui.

$\mathrm{R}$ desenha em silêncio.

E: Ficou bom. Agora vamos pra nuvem.

R: Beleza.

$\mathrm{R}$ desenha em silêncio.

E: Muito obrigado. 


\section{Desenhos Pré-teste: Rogério}

Girafa

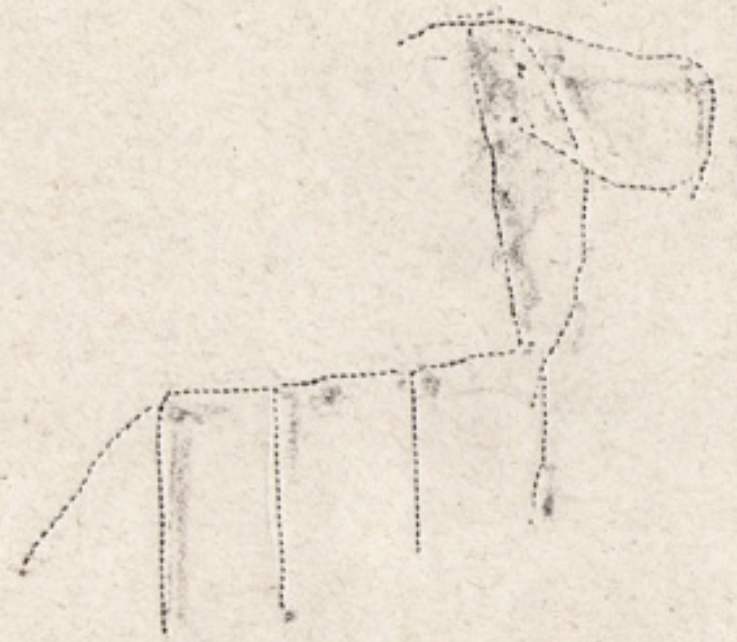

Nuvem

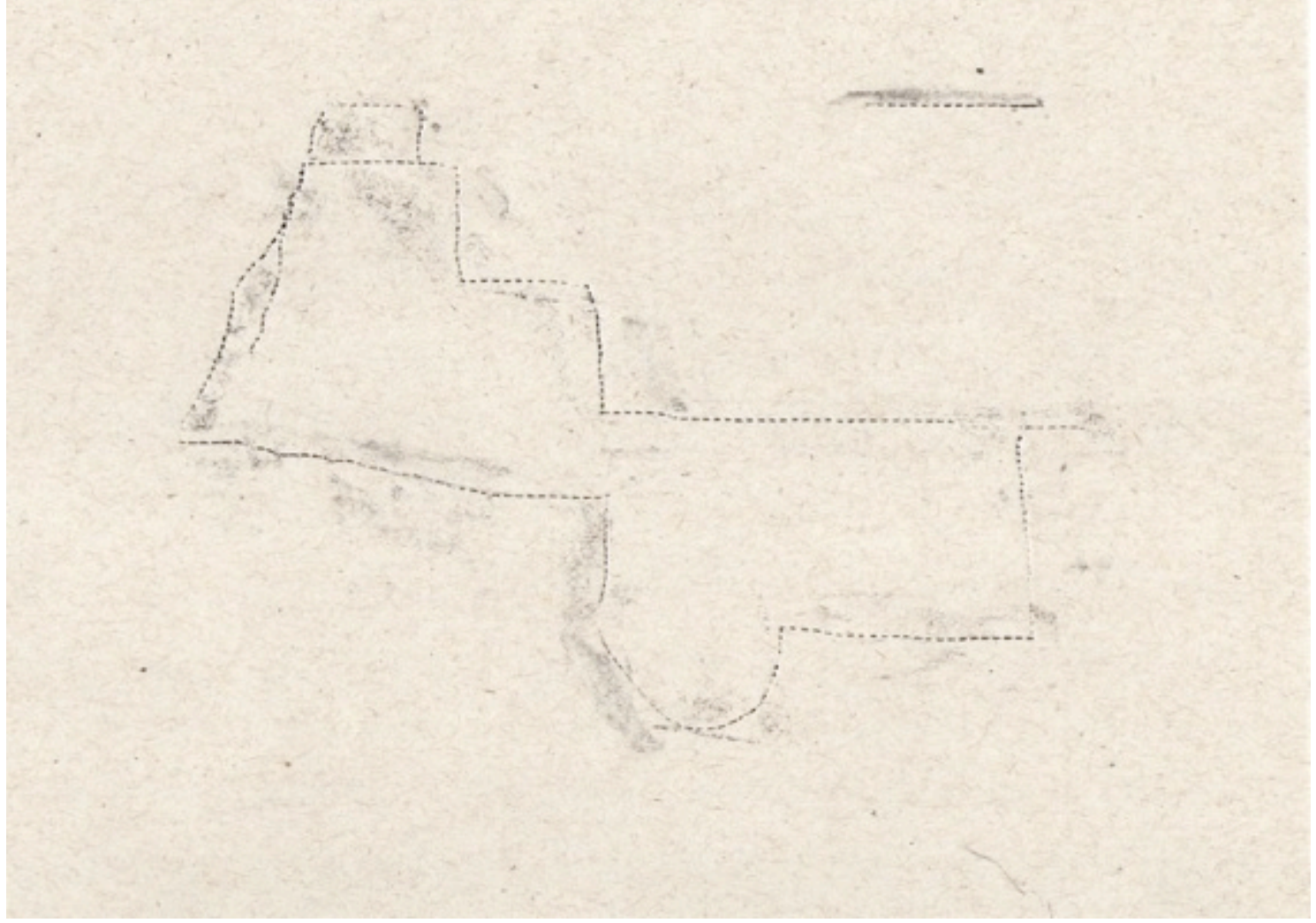


Montanha

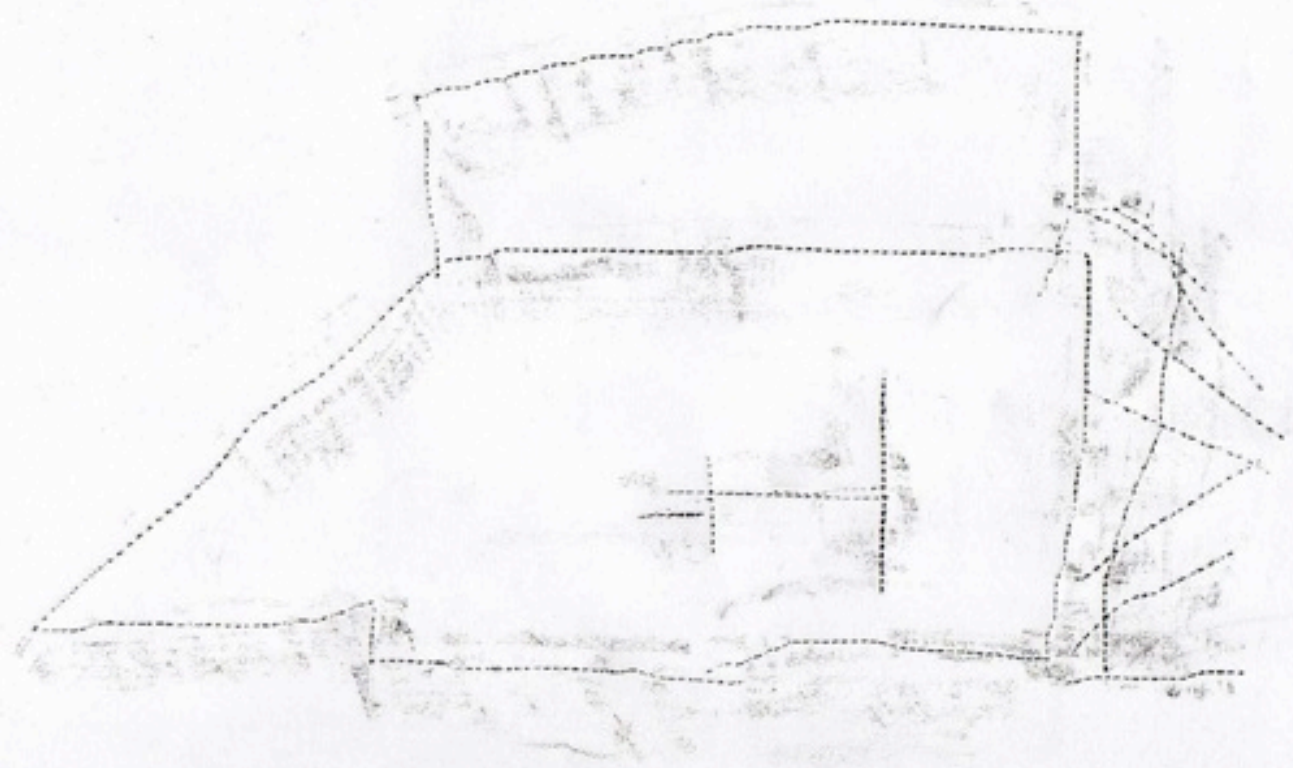

Árvore

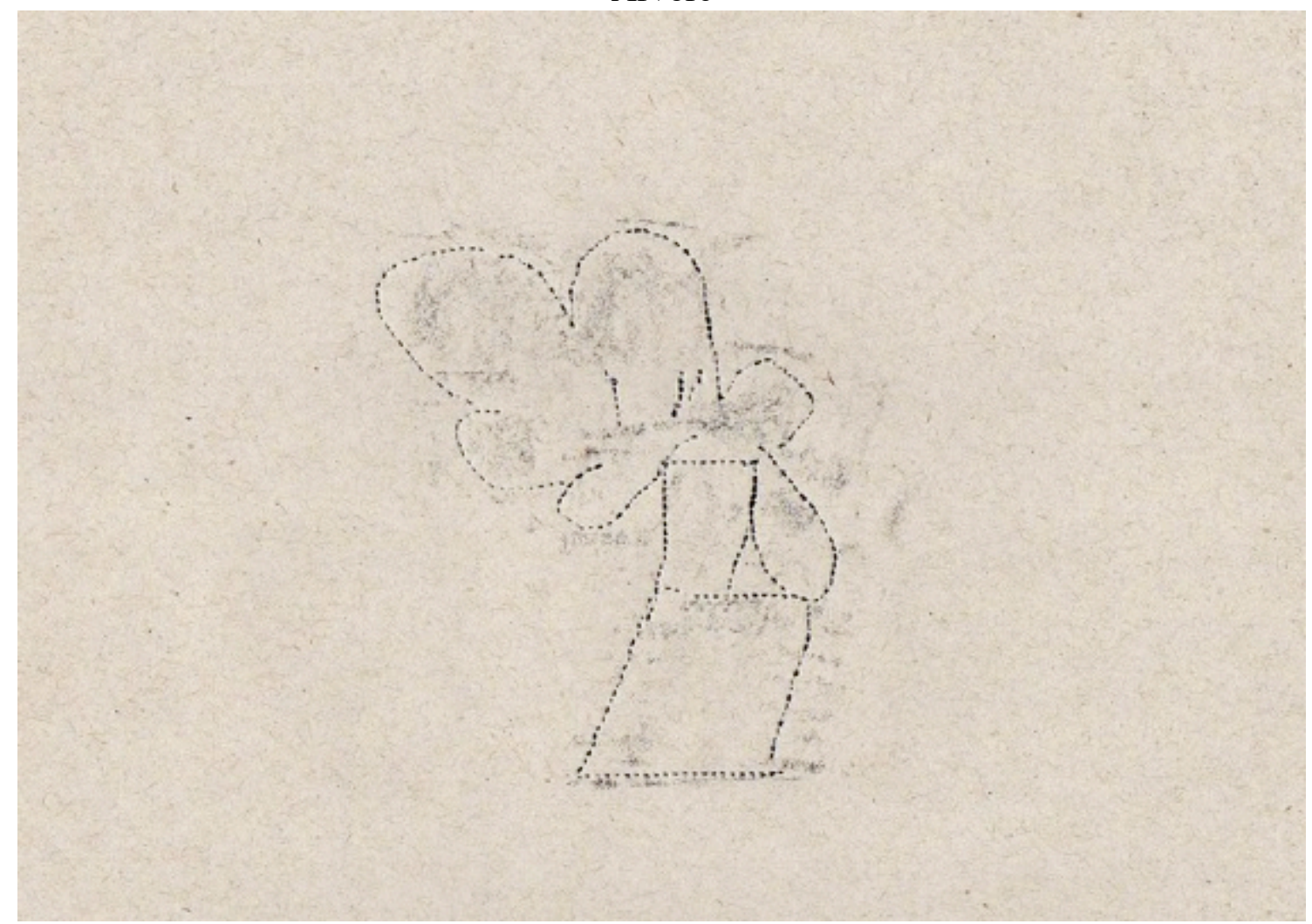


Trem

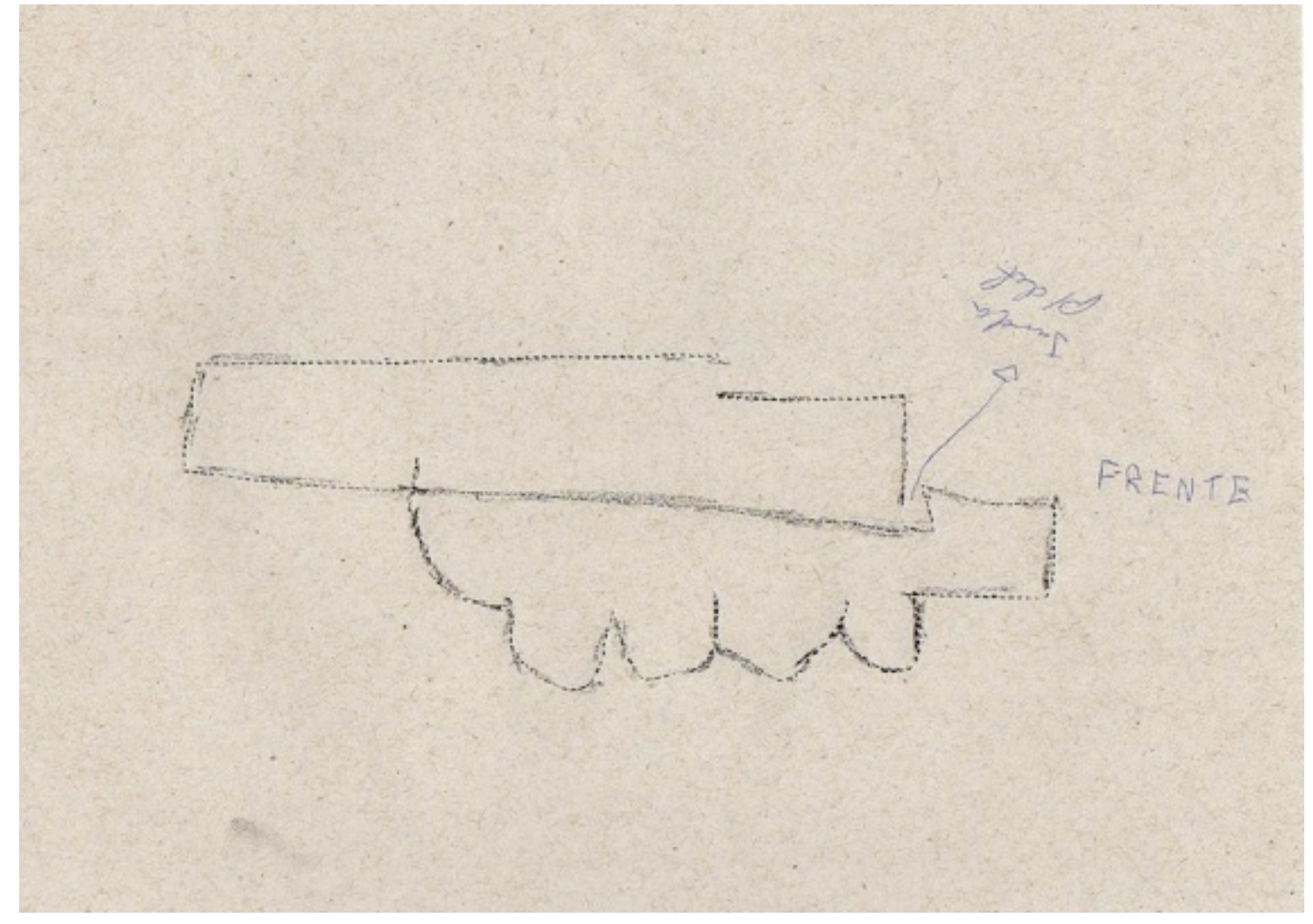

Leão

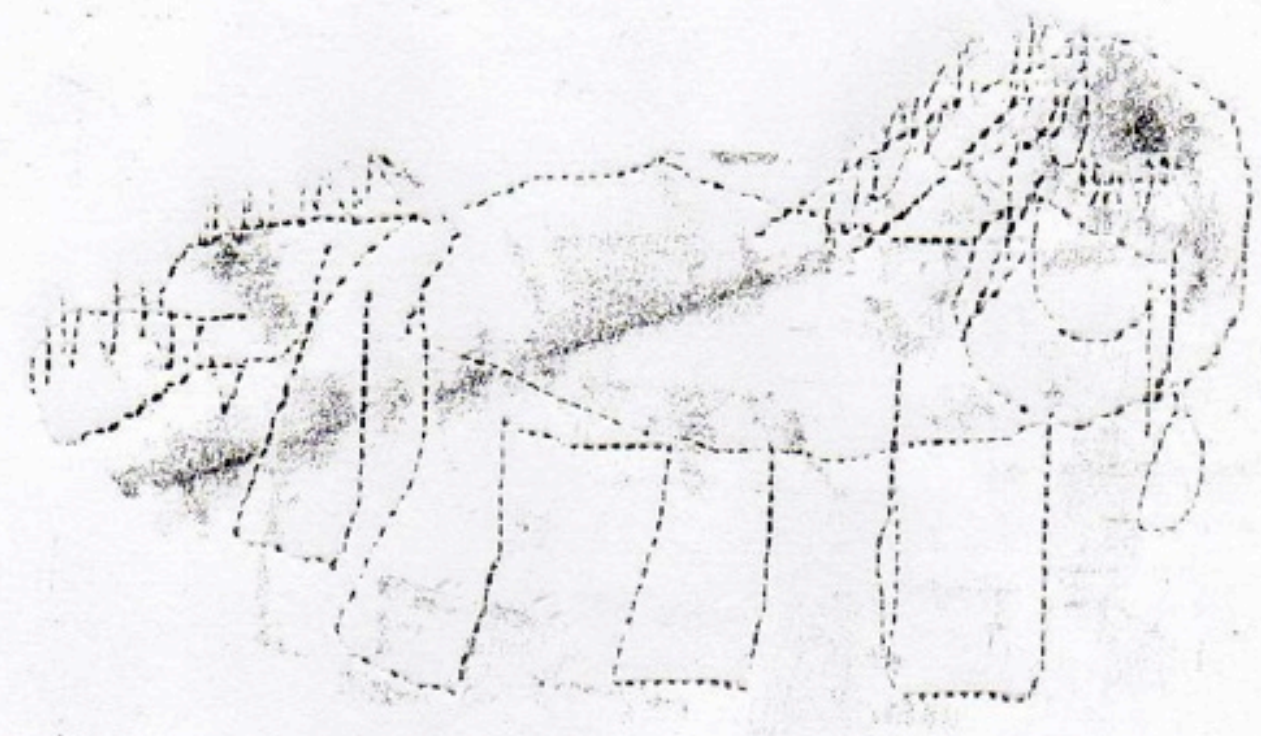


Prédio

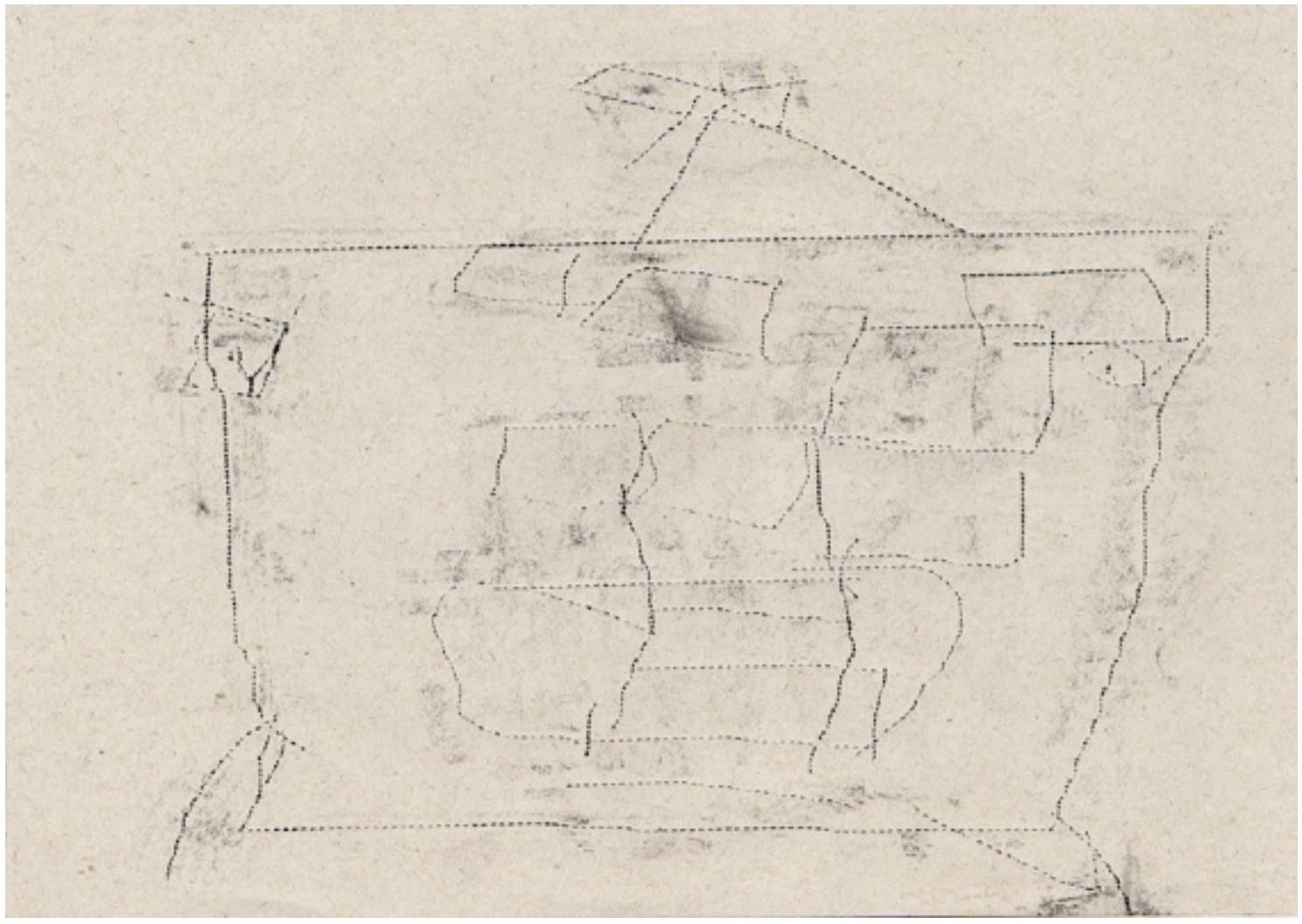

Ilha

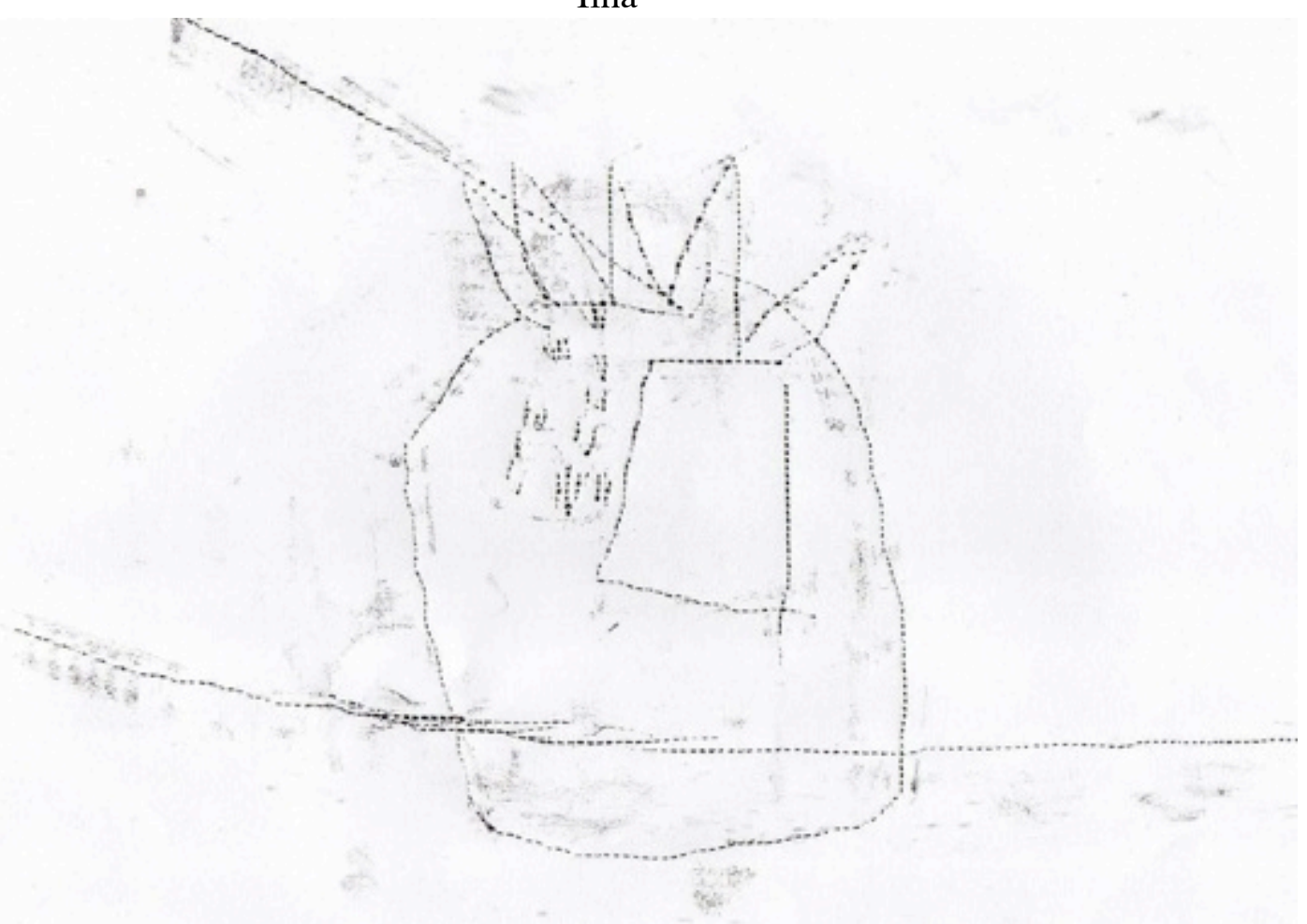




\section{Entrevista Pós-teste: Rogério}

E: Bom, agora eu vou te fazer umas perguntas, as mesmas que eu fiz da primeira vez, tá?

Perguntar pra você sobre algumas coisas e você vai me responder e depois você vai desenhar, tá bom?

R: Ok.

E: Bom, primeiro então que vamos falar é a girafa. Você pode me dizer o que é uma girafa?

R: Ela vive na África, come fruta, é... Fruta não, é... Folha da copa das árvores e toma água.

E: E como que ela é?

R: Ela é alta e... Mora na África do Sul.

E: Mais alguma característica da girafa que você lembrou da girafa, que você acha importante?

R: Ela se esconde também dos leão.

E: Tá certo. Então pode desenhar uma girafa pra mim.

$\mathrm{R}$ inicia o desenho.

R: Pronto.

E: Pronto? Você pode me explicar o que você desenhou?

R: Uma girafa filhote.

E: Uma girafa filhote? Quais são as partes dela?

R: Hum... A cabeça, as costa, esse daqui reto é o rabo e as pata dela.

E: Beleza, muito bom. Posso pegar? Vamos pro próximo então. Você pode me dizer o que é uma nuvem?

R: Vive no céu, ela é carregada de água...

E: Uhum.

R: E... Como eu vou... E... Tem, e quando se ajunta com aquelas nuvens negras, sabe, ela dá raios e trovão, acertei?

E: Muito bom, mais alguma coisa que você lembra da nuvem?

$R$ faz que não (com a cabeça).

E: Você pode desenhar a nuvem então pra mim?

$\mathrm{R}$ inicia o desenho.

R: Assim?

E: Legal!

R: E ainda desenho... E ainda faço a carinha dela.

E: Como é que é o formato dessa nuvem aí?

R: Ela vive no céu e ela tá sorridente. Ela tá... Sabe porque que ela ta sorrindo? Por causa que hoje não vai cair chuva.

E: Hoje não? E por que que você deixou ela feliz.

R: Por causa que eu quis deixar ela feliz assim.

E: Tá certo. Posso pegar? Vamos pro próximo então, você pode me dizer o que é montanha?

R: Sei! Ela tem terra, ela é um morro de barro, acertei?

E: Não se preocupa em acertar ou errar, vai dizendo o que você pensa.

R: Ela é um morro de barro e tem pedra, tem folha, raiz das folha.

E: A montanha tem folha e raiz? Hum.

R: Aqueles matinho de pracinha.

E: Você tá falando que... Ah tá.

R: Que tem no morro assim de um lado e tem no outro. Aí tem a terra no meio pra pessoa subir.

E: Entendi, entendi. Que mais?

R: E... Só. E tem árvores também em cima.

E: Em cima da onde? 
R: Da montanha.

E: Tá certo. Mais alguma coisa?

R: Dá até pra escorregar.

E: Dá pra escorregar da montanha?

$\mathrm{R}$ : Na onde eu moro dá.

E: Hum?

R: Lá perto da onde eu moro dá.

E: Você mora numa montanha?

$\mathrm{R}$ : Eu moro numa favela, e quando dia de domingo e feriado meu primo chama nós pra ir pra pracinha e nós vai.

E: Mas a praça fica numa montanha?

R: Aham.

E: É mesmo?

R: Tem a quadra não tem? Aí tem aquelas rede de ferro. Porque antes não tinha, não tinha nada, tinha um muro só assim, e não tinha nada deste lado e nem deste, tinha só a arquibancada. Aí eles ponharam a rede pra bola não ir pra arquibancada.

E: Mas aí você ta me falando como é a quadra, certo? E o que isso tem a ver com a montanha que a gente tá falando aqui?

R: Que quando nós vai, nós vai pelo morrão, aí nós desce...

$\mathrm{E}:$ Ah, entendi.

R: E pula dentro da quadra, nós pega, não tem a escada, assim, da... Da rede de ferro? Então, nós pega, sobe na rede e desce pela escada.

E: Entendi. Então isso que você sobe e desce é como se fosse uma montanha, isso que você ta dizendo?

R: Tem vez que nós vai pelo portão da quadra.

$\mathrm{R}$ inicia o desenho: Aqui é o barro.

E: Uhum.

R: E aqui tem folha também.

E: Tá. (pausa) O que é isso que você tá desenhando aí?

R: Árvore. (pausa) Ó o tanto de romã que tem nas árvores.

E: Romã?

R: Romã é um negócio que tem semente dentro, aquelas bolinha.

E: Uhum, você gosta?

R: Eu gosto, lá tem. Toma.

E: Pronto? Vamos lá então, vamos para o próximo. Você pode me dizer o que é árvore?

R: Posso.

E: Diga.

R: Tem folha, tem... É, folha. Tem aqueles negócios lá, romã que eu falei, romã, manga e coco.

E: Na mesma árvore.

R: Na mesma.

E: É mesmo?

R: Na árvore que nós, na árvore que meus irmão sobe tem romã, tem coco, tem tudo.

E: Olha só, uma árvore que tem várias frutas. Como que é uma árvore?

$\mathrm{R}$ : Ela é reta, sobe, ah e tem as copas das árvores onde tem as frutas.

E: Tá legal, você pode desenhar então essa árvore.

R: Ixi, vou ter que fazer as frutas lá em cima, vou ter que ir direto nas frutas.

E: Quer outra folha pra você tentar de novo?

R: Não.

E: Não? Então vai? 
$\mathrm{R}$ entrega o desenhador.

E: Pronto? Vamos pro próximo. Você pode me dizer o que é trem?

R: Posso.

E: Então vai.

R: Ele tem... É... Trem negocinhos. Aí tem aquele negócio lá.

E: Que negócio?

R: Vagão e tem o maquinista

E: Aham. E como ele é?

$\mathrm{R}: \mathrm{O}$ maquinista?

E: Não, o trem.

$\mathrm{R}$ : $\mathrm{O}$ trem ele tem três parte, e tem a do maquinista.

$\mathrm{E}:$ E quais são essas três partes?

$\mathrm{R}$ : Da locomotiva e tem uma parte, a última parte, a parte do meio quer dizer, que tem aquela geladeira lá que se abrir já era o trem.

E: Geladeira?

R: Aqueles negócios de latinha de geladeira.

E: Geladeira igual tem na cozinha.

R: É, mas só que é diferente. Se você abrir o trem já era.

E: Não conhecia isso não, não sabia que trem tinha geladeira.

R: Não tem que é assim. Ele é igual geladeira.

E: Ah, ele é igual geladeira, mas não é uma geladeira.

R: É.

E: Acho que agora melhorou pra entender. Tá bom. E a última parte?

R: É do maquinista.

E: Ah, onde fica o maquinista. Tá legal. Vamos desenhar o trem?

$\mathrm{R}$ inicia o desenho.

R: Tá amassando.

E: Pronto, eu tô segurando aqui pra você.

R: Um, dois, três.

E: Muito bem, posso pegar? Agora queria que você me explicasse o que é leão.

R: Ele vive na África, come carne e... Corre. Corre pra pegar animais.

E: Que mais? Como que ele é?

$\mathrm{R}$ : Ele pode ser qualquer cor. Ele pode ser alaranjado ou amarelado

E: Ele tem alguma característica específica?

$\mathrm{R}$ : Correr pra pegar animais.

E: Tá certo. Mais alguma coisa sobre o leão?

R: Não.

E: Pode desenhar.

$\mathrm{R}$ inicia o desenho.

E: Esse leão tem o que?

R: Pronto, meu leão tem juba.

E: Juba? O que é a juba?

R: O cabelo dele.

E: Fica aonde?

$\mathrm{R}$ : Aqui nas costas.

E: Tá legal. Beleza. Próximo. Você pode me dizer o que é prédio?

R: Hotel.

E: Explica melhor o que é prédio.

$\mathrm{R}$ : Tem andares, tem elevador, tem escada.

E: Aham. 
R: E salão, tem cozinha também. Só isso.

E: Não tem mais nada esse prédio?

R: Ah e tem quartos.

E: Quartos? Tá bom. Você tá me falando de um prédio ou de um hotel.

R: Dos dois.

E: Qual é a diferença?

R: Que o prédio é mais baixo que um hotel.

E: Tá bom. Tem prédio que não é hotel?

R: tem. Prédio de construção.

E: Mais um tipo de prédio que não é hotel? O resto, todos os prédios são hotéis?

$R$ faz que sim com a cabeça.

E: Tá bom, pode desenhar então.

$\mathrm{R}$ inicia o desenho.

E: Que parte é essa que você tá desenhando?

R: Eu já fiz, é da parte da onde, da onde, esqueci o nome dessa parte aqui.

$\mathrm{E}: \mathrm{E}$ as outras?

R: As outras são tudo que tem quartos.

E: E essa parte do lado que você fez do lado?

R: Essa parte é o estacionamento aqui.

E: Tá legal. Beleza. Bom, agora eu quero que você me diga o que é ilha.

$\mathrm{R}$ : Água, terra e ar.

E: Ilha é água, terra e ar? Explica um pouquinho melhor.

R: A ilha tem água, a terra, e tem árvore e pode ter ilha que tem casa nela.

E: Tá legal, você pode desenhar pra mim?

R: Uhum.

E: Só uma pergunta, a água fica dentro ou fora da ilha?

R: Em volta.

E: Entendi.

$\mathrm{R}$ inicia o desenho: Ó, essa parte aqui que tem alta, é tudo água, menos essa parte aqui.

E: Tudo que tá em volta é água. Tá bom.

E: Que mais você desenhou aí?

R: Casa.

R: Pronto.

E: Tá certo, muito obrigado. Por hoje é só.

$\mathrm{R}$ : De nada. 
Desenhos Pós-teste: Rogério

\section{Girafa}

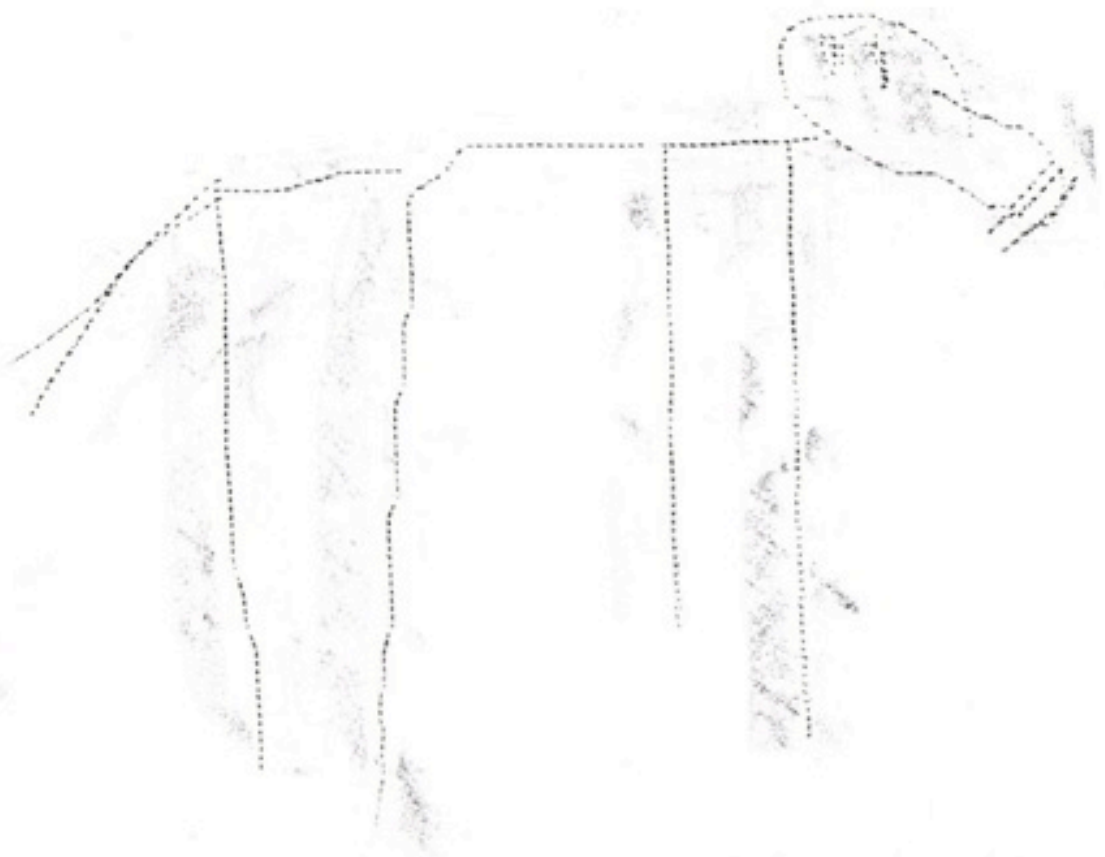

Nuvem

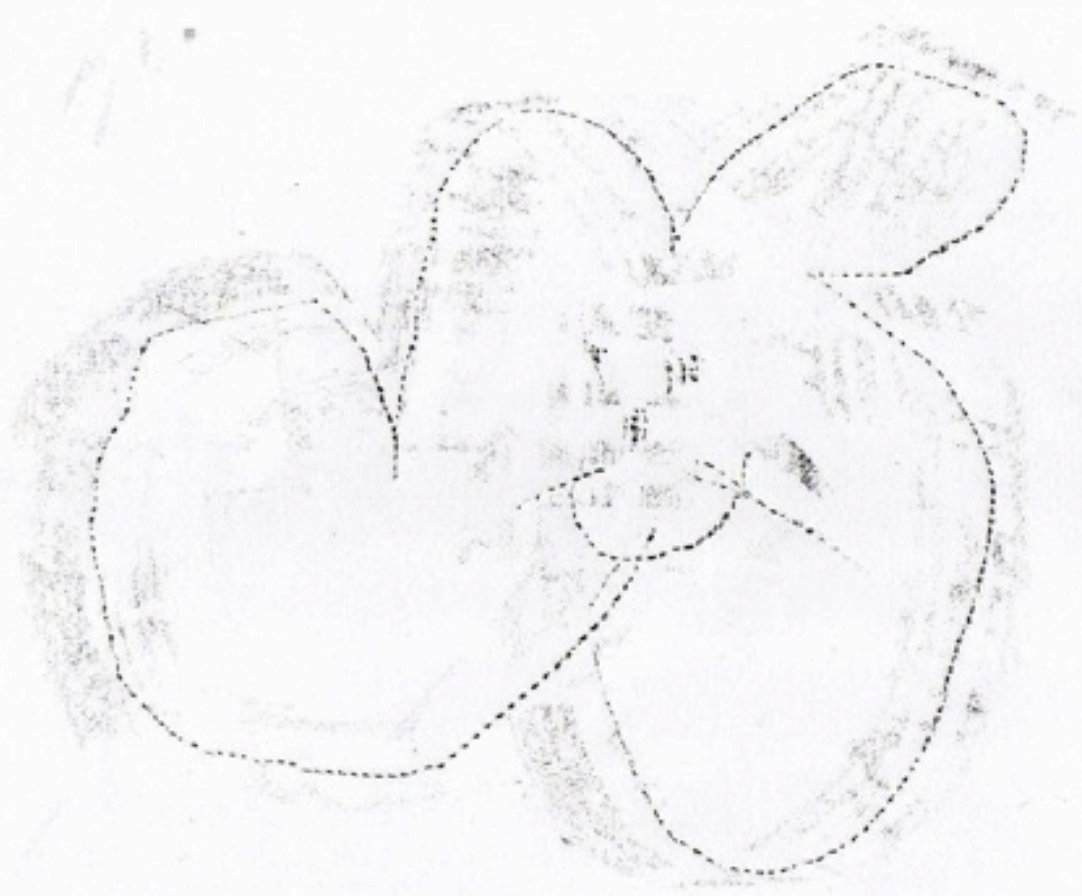


Montanha

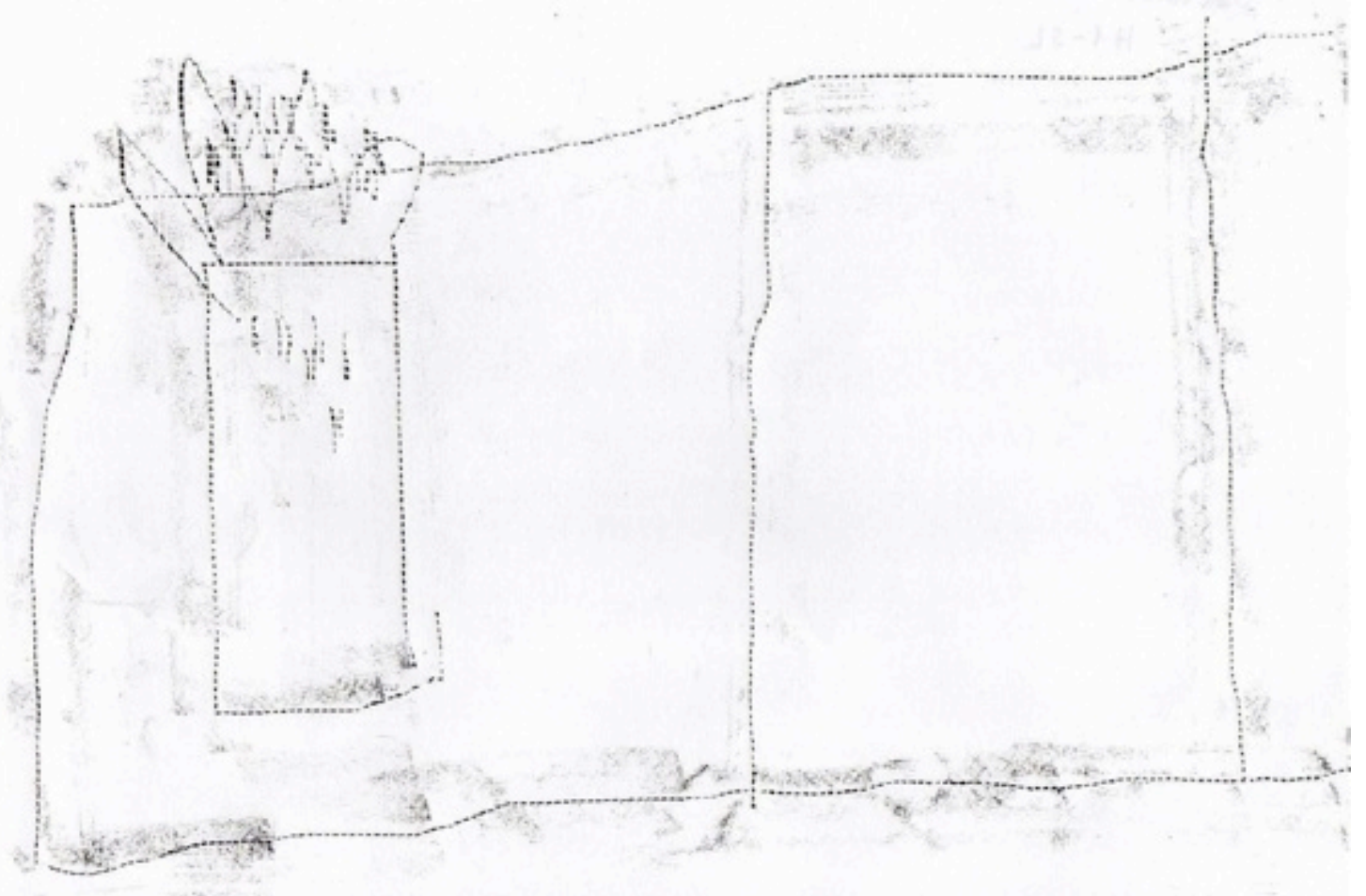

Árvore

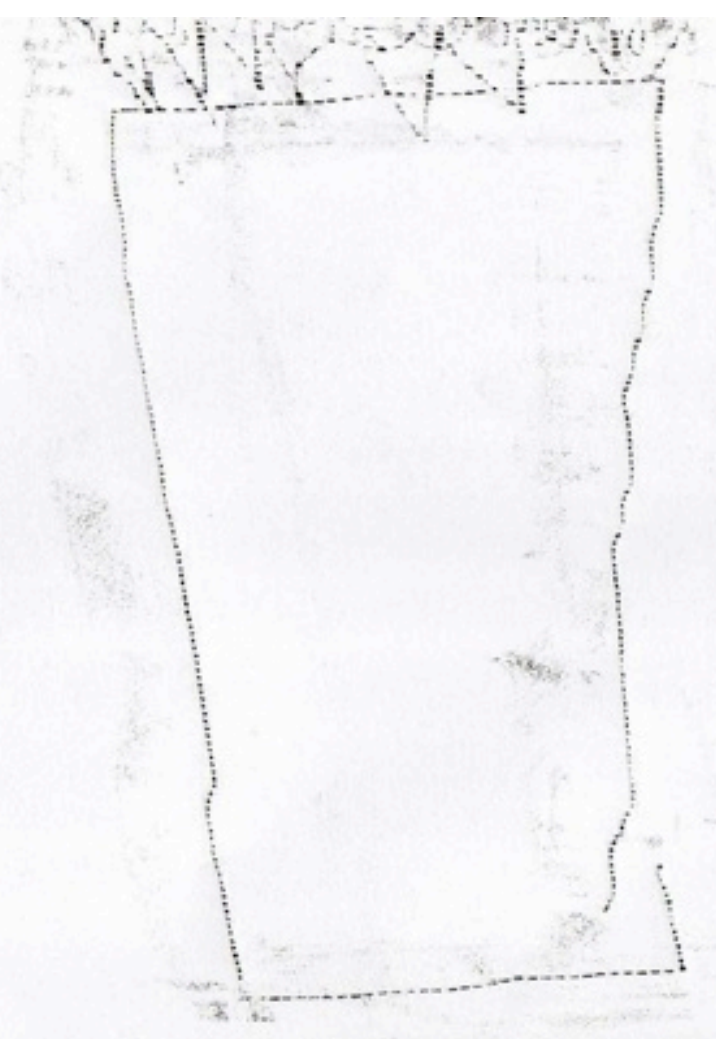




\section{Trem}

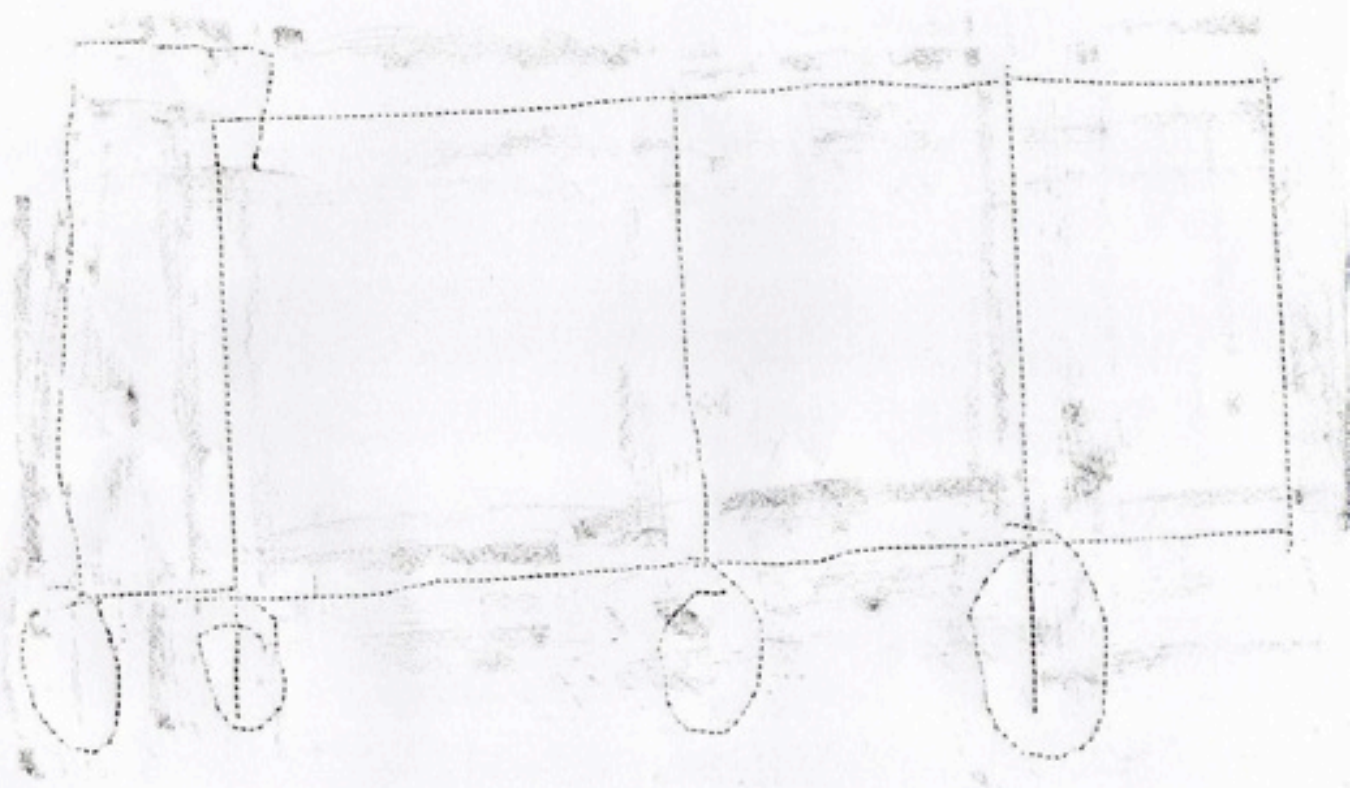

Leão

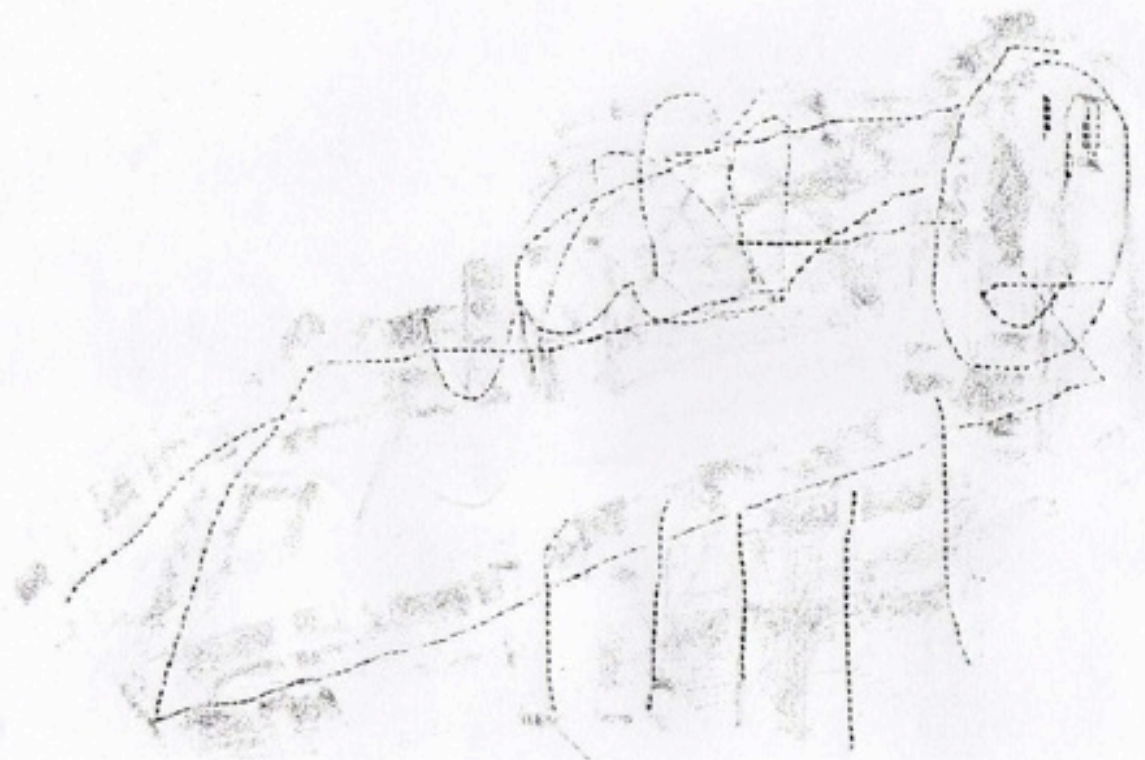


Prédio

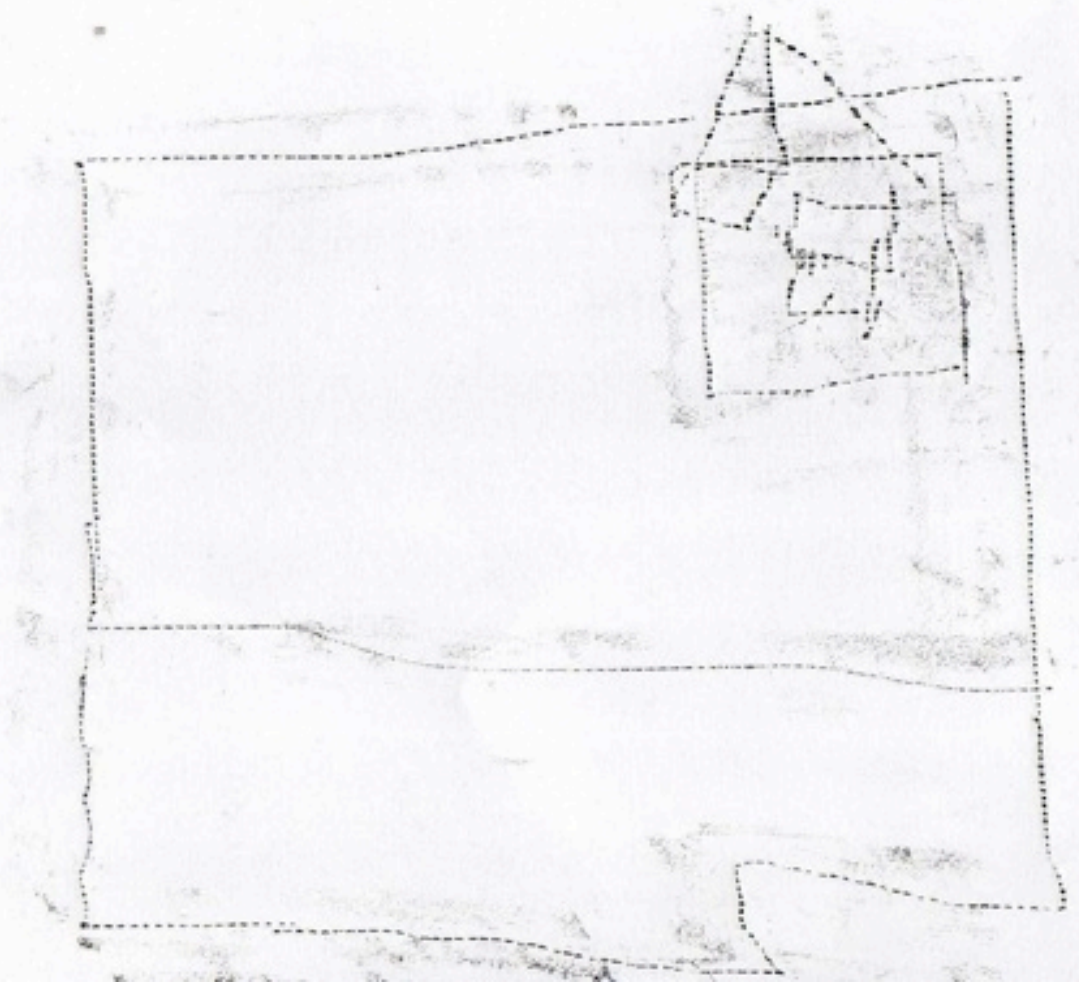

Ilha

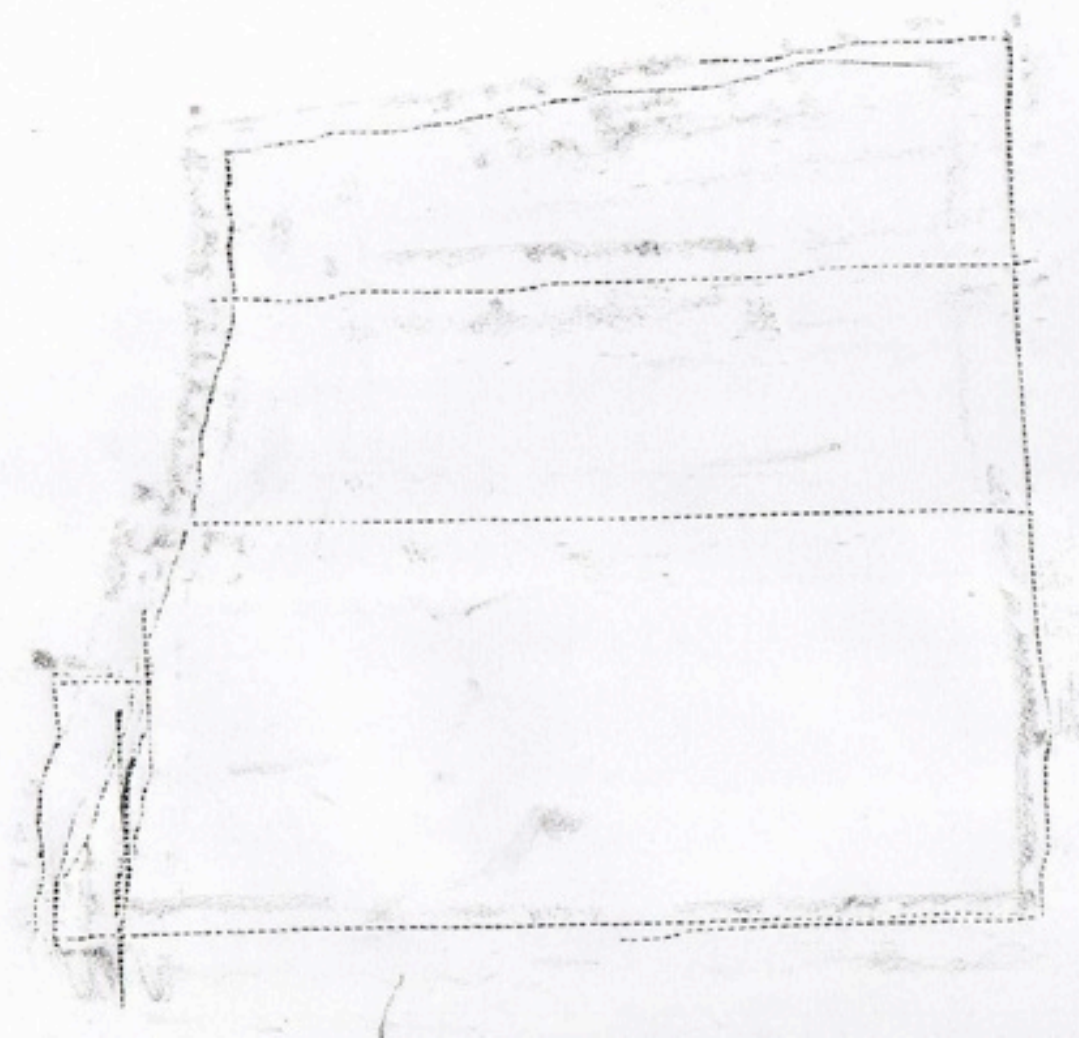




\section{Entrevista Pré-teste: Fábio}

E: Então vou te fazer algumas perguntas sobre algumas coisas, tá bom? Você vai definir pra mim essas coisas que eu vou te perguntar sem se preocupar se tá certo ou errado, tá? O que me interessa é entender como você pensa, como você faz e não é o meu objetivo avaliar se você sabe ou não sabe, tá bom?

F: Tá.

E: Depois que eu te fizer as perguntas que são verbais, eu vou te mostrar alguns desenhos pra você tentar identificar e depois vou pedir pra você fazer, reproduzir esses desenhos que você descreveu, tá bom?

F: Tá.

E: Então vamos lá. Bom, primeira coisa que eu quero que você defina pra mim: girafa.

F: Girafa?

E: Isso.

F: É um animal.

E: O que mais? Que tipo de animal?

F: (pausa) Como assim?

E: Fala mais, como que é esse animal? Onde ele mora, onde ele vive?

F: Ele mora na floresta.

E: Na floresta? Hum, e como ele é?

F: Pescoçudo, pescoçudo assim, grande. (gesticula)

E: Mais alguma coisa que você lembra?

F: Não.

E: Como você sabe que a girafa é assim?

F: Ah, quando eu era pequeno eu lembro que as pessoas me falavam. Quando eu era pequeno eu já tinha uns bichinhos assim, de brinquedo assim, e desses bichinhos tinha a girafa. Aí eu consegui ver como que era.

E: Ah legal. Muito bom. Beleza. Próxima: Você poderia me dizer o que é nuvem?

F: Nuvem é... (pausa) A nuvem é um... (pausa) É a água que sobe né? Que sobe né?

E: É o que?

F: Que sobe né? É... (pausa)

E: Água que sobe... E vai pra onde?

F: E vai pra atmosfera né?

E: Pra atmosfera? Ahn?

(pausa)

E: E como que será que é uma nuvem?

F: Como assim?

E: Que forma que ela tem? Você acha que ela é grande?

F: Ah, eu acho que ela é uma curva assim (gesticula). Que ela vai... Uma curva assim né? (gesticula) Ah ela não é pequena nem grande, ela é média.

E: Tá, beleza.

F: Meio termo.

E: Meio termo. Que mais você sabe sobre nuvem?

F: Ah, quando elas se esbarram forma um trovão né?

E: Uhum, quando uma esbarra na outra forma trovão?

F: Por isso que faz aquele barulho.

E: Mais alguma coisa?

F: Eu acho que... As vezes eu acho que. A velocidade da luz né. A luz é mais rápida que o som né?

E: Você sabe bastante coisa hein? Onde que você aprendeu tudo isso? 
F: (sorri) Hum... Televisão. Fiquei perguntando, as pessoas que falam também.

E: Legal. Muito bem. Próximo. Montanha.

(pausa)

E: O que é montanha?

F: (pausa) Como que eu posso explicar, acho que é uma...Ela é uma... É uma... Como que fala... Eu sei que ela é feita de rocha, né? Ela é como se fosse uma rocha assim bem grande. (pausa) Eu acho que, eu acho que. Bom, montanha eu acho que, eu acho que, bom, montanha acho que não tem um buraco no meio, mas vulcão sim.

$\mathrm{E}:$ Ah, vulcão tem buraco no meio e a montanha não?

F: E a montanha não. Mas os dois acho que são parecidos porque vulcão parece uma montanha.

E: Bem pensado, verdade. Legal. Mais alguma coisa que você lembra sobre montanha?

F: Não.

E: Beleza. Próximo. Árvore.

F:(pausa) Árvore é um... Bom, feito com galho né. Com galho...

E: Feito com galho...

F: Ela é... Ela é áspera, né?

E: Entendi.

F: É dela que tira o papel né? A gente usa.

E: Entendi. Você costuma tocar as árvores?

F: Ah eu costumo, mas material, material, não sei, acho que é madeira né?

E: Ah...

F: Tem árvore que é fina, tem árvore que é grossa. O tronco dela é áspero, né.

E: Você conhece muitas árvores? Tem árvore no lugar que você mora?

F: Não, mas eu já fui em lugares, onde tem.

E: Ah, e aí você põe a mão nas árvores.

F: Sim.

E: Legal. Então você falou que ela tem tronco...

F: Isso, galho...

E: Galho de madeira.

F: Raiz também.

E: Raiz.

F: É... E dela que se tira o papel, né?

E: Muito bom, vamos pro próximo. Trem.

F: (pausa) É tipo... É um meio de transporte né? É que nem automóvel só que em vez de ele se locomover na... Na terra ele vai por baixo, vai por baixo na... Na terra não, como que fala, no asfalto, ele vai se locomover na... É... No trilho né.

E: Uhum, como que é o trem? Que diferença que ele tem pro carro além do lugar que ele se locomove?

F: Além do, além motor, além do motor dele é elétrico né, e o carro não tem luz assim em cima né. Ah mas ele tem assim... Só que o motor do trem é elétrico e o carro funciona a combustível.

E: Você costuma pegar ou andar de tem?

F: Oi?

E: Você já andou de trem?

F: Já. Tem um maquinista né. O carro não tem, e o trem é maior né.

E: O trem é grande?

F: Não sei quantos vagões né? Mas... Enorme.

E: Legal. Mais alguma coisa que você sabe do trem?

F: Mais barulhento também. 
E: Mais barulhento que o carro?

F: Isso.

E: Então beleza. Vamos lá. Leão.

F: Leão... Um leão é um animal grande assim, grandão assim, a boca dele é enorme e ele é peludo, né. Acho que na floresta, se eu não me engano, o leão.

E: Que mais?

F: (pausa) Bom, o leão é um bicho selvagem né?

E: Como um bicho selvagem?

F: Oi?

E: Como assim um bicho selvagem?

F: Ah ele é assim, um bicho assim, agressivo né?

E: Ah, agressivo?

F: É.

E: Agressivo com quem?

F: Agressivo... Ele... É um animal que você não pode mexer, você não pode chegar perto. Você não deve confundir o leão com seu cachorro, o seu cachorro você confia né? Se você cuidar bem assim o cachorro não vai te fazer nada, agora o leão...

E: O que ele faz?

F: O leão se chegar perto dele ele morde né?

E: Tá certo. Mais uma coisa que você sabe do leão?

F: Não.

E: E onde você aprendeu tudo isso sobre o leão?

F: (pausa) Nos meios de comunicação.

E: Tá legal. Vamos lá. Próximo. Prédio.

F: Bom é um... Prédio é um... É uma... Como que fala... É um... Uma casa né. Ela tem andar né?

E: Uhum.

F: E.. (pausa) Como se fosse... Prédio é assim, é bem maior do que acho que apartamento né?

E: Hum.

F: Ou não? Ou apartamento pode ser a mesma coisa?

E: O que que você acha?

F: Ah, quando se falam em prédio acho que eu penso... Ah, acho que a maioria vinte andares assim pode ser um prédio né? Agora quando é uns cinco, quatro andar seis, sete, até acho que dez é apartamento.

E: Até dez andares é apartamento e maior seria prédio?

F: Oi?

E: Até seis andares seria apartamento mais de seis seria prédio, é isso?

F: Não, mais de... acho que dez andares.

E: Entendi. Você mora em casa ou mora em prédio? Ou mora em apartamento?

F: Casa.

E: Você já visitou algum prédio?

F: Bom, já visitei da Pinacoteca, que é um museu de artes.

E: E como você sabe que era um prédio?

F: Bom, é que, além das pessoas me falarem tinha a maquete né. Tinha a maquete lá dentro, do próprio... Do prédio né?

E: O prédio, que prédio que você viu na maquete?

F: O prédio da Pinacoteca, onde estava. Tinha escada, tinha elevador. Ela tem acho que uns, não sei quantos andares, mas deve ser... É, mais de doze eu acho.

E: Entendi, e você foi em todos os andares?

F: Não. 
E: Quantos andares você visitou? Você lembra?

F: Ah, acho que uns dois, três.

E: Entendi. Tá legal. Lembra de mais alguma coisa sobre prédio?

F: Não.

E: Então vamos lá. O último esse, tá? Ilha.

F: Ah, ela é um, é uma, acho que é uma coisa de terra e ela é cercada de água.

E: E como é que você sabe?

F: Bom, mas, desde acho que, acho que desde quando eu era pequeno, acho que até uns doze, treze anos eu não sabia né. Aí a minha professora de artes falou que ilha é... Hum, acho que é terra e em volta tem água né. Porque eu pensava que ilha era uma casa.

E: Pensava que ilha era o que?

F: Pensava que ilha era uma casa. Até uns... Não... É, até uns doze, treze anos eu não sabia o que era ilha.

E: Aí com a professora de Artes você aprendeu.

F: Aí a professora de Artes me ensinou.

E: E ela... Essa professora de Artes te mostrou algum desenho, alguma forma da ilha na aula de Artes?

F: Acho que a ilha é um... É tipo... Acho que é um círculo e tem água em volta da ilha é água, e no meio é terra.

E: Tá legal. Legal essa definição de ilha, gostei, bacana. Agora eu vou te mostrar, F., três desenhos que representam essas coisas que nós conversamos, tá? Que são três, três desenhos de definições que eu te pedi. Vê se você consegue identificar, tá? Não se preocupe em acertar ou errar, mas vê se tem pista aí do que que é.

F. toca.

E: O que você tá percebendo aí?

F: Hum... Isso aqui é um prédio, isso aqui? (pausa) Parece que é uma nuvem aqui?

E: Por quê? O que você tá sentindo?

F: Por causa que tem umas curvinhas. Aí eu pensei: Ah, acho que é nuvem.

E: E o resto?

(pausa)

F. É que eu ainda não tenho idéia do que seja esse desenho. É de quantos desenhos são?

E: Aí tem um só.

F: Só tem um?

E: É, é uma coisa. Tem bastante detalhe né?

$\mathrm{F}$ : Tem.

E: Eu vou te descrever. Essa parte embaixo, essas curvinhas, são rodas. Aí em cima das rodas você vai notar os retângulos, que tem um espaço entre um retângulo e outro. Que coisa poderia ser?

F: Um trem. Um trem cheio de detalhe né?

E: Não tem problema, a gente vai conhecendo.

F: Quantas rodas são no máximo um trem?

E: Depende do tamanho do trem né C.? Essa aí quantas tem, será?

F. conta

F: São nove? Aqui to contando nove.

E: São nove rodas e tem quantos vagões?

F: Vagões são esses daqui né? Esses quadradinhos.

E: Isso, o retângulo.

F. conta

F: Três. 
E: Isso, três vagões e tem nove rodas. Acho que depende do número de vagões né? Esse é um desenho, F. não corresponde a um trem de verdade, né? Sinceramente eu não sei quantas rodas tem.

F: Eu nunca vi um vagão de um maquinista.

E: É o primeiro. Olha só, o primeiro ele é mais pontudinho na frente.

F toca: É o primeiro?

E: Não, tá lá do outro lado. Isso. Então a ponta... Esse aí é um trem movido a carvão né?

F: Carvão.

E: Então ele vai ter uma chaminézinha no canto de cima, vê se você consegue achar. Soltando uma fumacinha.

F: Ah, aqui a chaminé.

E: Isso, exatamente. Aí depende né, os trens da cidade não são mais assim, são elétricos né.

F: Tudo elétrico né?

E: Tudo elétrico, como você falou. Posso te mostrar outros desenhos?

F: Sim. Você já viu como funciona o metro? Nunca né?

E: Por dentro?

F: Como funciona o vagão do maquinista assim.

E: Ah, nunca entrei não. E esse aí, vê se você consegue identificar o que é.

F toca.

(pausa)

F: Deve ser um prédio isso aqui.

E: Por que você acha que é um prédio?

F: Aqui é como se fosse um prédio e aqui é como se fosse os andares, eu acho.

E: Legal, é isso mesmo. Acertou.

F: É?

E: É. Quantos andares tem esse aí?

F conta: Conto a partir daqui né?

E: Isso é tipo uma antena, a parte de cima do prédio né? Os andares são esses quadrados menores aí. São janelas, esses seriam os apartamentos né? Aí o andar você conta de baixo pra cima, conta pelas janelas por exemplo.

F: E aqui?

E: Aí seria a parte térrea né, a janela, aí a porta.

F: Aqui é a porta?

E: Isso. A porta de entrada, aí você tem um andar, outro andar.

F: Tem seis.

E: Tem seis apartamentos. Mas andares, andar você conta de baixo pra cima.

F: Aqui né?

E: Esse é o térreo, aí vai ter o primeiro.

F: Segundo sobe dois.

E: Isso, dois andares. Esse tá fácil hein? Vamos ver outro? Isso aqui tem bastante detalhe, vamos ver se você consegue identificar. Pronto, esse é o último.

F. toca.

F: Eu to em dúvida entre dois desenhos.

E: Ahn. Fala quais são que eu te ajudo.

F: Eu não sei se é árvore ou é ilha.

E: As duas coisas. As ilhas, geralmente, F., quando aparece desenho de ilha, esses desenhos mais simbólicos né, a ilha tem um coqueiro, tem uma árvore no meio. Então isso que você tá achando que é árvore e é mesmo, é um coqueiro. E a parte de baixo...

F: Toca. 
E: Isso. Tem a ilha que é aquele círculo que você falou né? Aí tem uma linha horizontal que é como se fosse a água.

F: Ah tá, bem aqui.

E: Não, esse é o coqueiro ainda.

F: Ah tá.

E: Vai ter uma linha, quase que uma linha reta.

F: Ah aqui... Ah...

E: Isso. Como se fosse a água, o mar, o nível do mar. Aí tem o círculo que é a ilha.

F: Ah...

E: E esses detalhes aí é como se fosse areia né.

F: Uhum.

E: Detalhes dentro do círculo. Esse tem bastante detalhe, né?

F: Uhum.

E: Mas ficou bacana né?

F: É.

E: Obrigado, F. Agora eu vou pedir pra você escolher desses desenhos que eu te mostrei qual que você quer desenhar. Aí você vai tentar desenhar.

F: Mas tem que ser do jeito que tá ali.

E: Não, faz do jeito que você quiser, só pra eu ver como você faz, tá? Não se preocupa não.

F: Então acho que eu vou fazer o segundo, segundo desenho, que é o prédio.

E: Tá bom. Então tá. Aqui tem a tua prancha, que você já tá acostumado, você prefere assim ou prefere por na horizontal? Tá na vertical aí?

F: Não, assim é melhor.

E: Assim é melhor? Então vou te dar caneta tem uma ponta de metal, aí você pode fazer o desenho. Faz despreocupado, tá? Quero ver como você faz depois você me explica o desenho.

F. toca a folha e inicia o desenho.

E: Vou segurar aqui a prancha pra você pra não escorregar, tá bom?

F: Mas é só pra fazer o desenho.

E: Isso, desenha o prédio aí que você falou que ia desenhar, depois te dou outra folha pra fazer outros que você quiser, tá?

F. continua a desenhar.

E: O que que você fez até agora?

F: Bom aqui é... Como se fosse... Bom eu expliquei né, essa linha aqui do meio, ou ainda não?

E: Explicou, que você faz uma linha média, né?

F: É, a linha dele só é a terra, né? Pra você não se perder.

E: Então o seu prédio tá embaixo da terra?

F: Oi?

E: Seu prédio tá embaixo da terra então?

F: Não, aqui é o céu, e aqui é a terra.

E: Ah, entendi.

F: Aí eu já desenhei o prédio, só falta os andar.

E: Tá legal.

F. volta a desenhar

E: Quantos andares você fez?

F: Sete. Tem dois aí que não tinha mais lugar.

E: Sem problema.

F. toca: Tem seis.

F. desenha por minutos.

E: Que capricho, hein?

F: ri e volta a desenhar. 
F: Pronto.

E: Pronto? Posso ver?

F: Pode. (espreguiça)

E: Nossa quanta janela que você fez hein?

F: Oi?

E: Legal. Olha só como ficou.

F: Nossa, saiu legal só que... É...

E: Que parte é essa aí?

F: Qual?

E: Essa que você quer falar. (pausa) Conta pra mim o que tem nesse desenho. As janelas, e isso aí?

F: Aqui é o prédio né, tudo aqui. Aqui é assim, como se fosse andar.

E: Tá.

F: Isso aqui... (pausa) E. vira a folha. (pausa) Bom, aqui são, deixa eu ver, um, dois, três, quatro, cinco, seis, sete, oito, nove. São nove andares.

E: Legal.

F: Nove... Aqui é o prédio, aqui embaixo é a porta, e aqui do lado esquerdo é tipo um elevador mas eu não sei como que desenha.

E: Onde que é o elevador?

F: Aqui, é como se fosse um elevador pra arrumar os vidros. É que são três elevadores aqui, e aqui é a porta, e aqui é as escadas, aqui. A porta, aí a escada aqui.

E: Ah entendi, posso pegar?

F: E aqui é outro elevador.

E. retira o desenho: Legal. Quer fazer mais um?

F: Não sei, porque não vou ter tanta criatividade como nesse.

E: Não tem problema não, se você quiser fazer mais simples tudo bem. Quer tentar fazer um trem ou uma ilha?

F: Tá.

E: Qual você prefere?

F: Acho que prefiro a ilha.

E: Pode fazer do seu jeito, F., não se preocupe.

F, referindo-se a régua: Aqui é pra segurar a folha?

E: Isso aqui é tipo uma reglete. Quer ver, olha?

F. passa a mão: Ah tá, ah. Entendi.

E: Aí você abre, e tem os furinhos pra fazer o braile. Você sabe escrever na reglete?

F: Saber mesmo...

E: Esqueceu?

F: Esqueci.

E: Você tá usando máquina e computador, né?

F: O computar lá em casa tá ruim; é, máquina e computador mesmo, que eu tô usando.

E: Legal.

F. começa a desenhar.

E: O que você vai fazer agora é a ilha, né?

F: É.

E: Tá.

F: Tsc.

E: O que foi?

F: A ilha saiu quadrada, não é pra sair quadrada.

E: Quer fazer outra? Te dou outra folha, quer?

F: Uhum. 
E. troca a folha: Pronto.

Fábio inicia o desenho.

E: E agora?

F: Ah, agora tá bom.

(pausa)

E: O que você ta fazendo agora?

F: Ah, eu comecei o formato da água. É, a água não tem formato.

E: É verdade.

F. continua a desenhar.

F: Será que tem árvores em casa?

E: Tem, tem árvores em casa sim.

F. desenha.

E: Você tá fazendo umas casas aí, é isso?

F: Sim.

F. continua.

F: Pronto.

E: Pronto?

F: Uhum.

E: Tá. Pode virar a folha? (E. pega o papel) Dá uma olhada. Aqui são as casas que você fez, né?

F: Isso.

E: E a ilha é pro outro lado.

F: Parece que tá de ponta cabeça.

E: Não, só virei o papel.

F: Ah.

E: Igual quando você faz o braile individual, sabe?

F: Isso... Ah... Aí esses ponto aqui é tudo o oceano, é o oceano tudo. Aí tem umas casas aqui. Parece que a casa saiu na... Eu fiz acho que, eu fiz casa na direita aqui e o papel saiu no lado esquerdo.

E: É, porque inverte.

F: Ah tá.

P. mostra o outro lado.

F: Ah tá, por isso que eu não tava conseguindo explicar o meu desenho.

E: Igual no braile, sabe? Que escreve de um jeito quando você vira a folha fica de outro, né?

F: Ah. Entendi.

E: Legal? Vamos tentar desenhar o trem?

F: Sim. Eu não consegui pegar os detalhes do trem.

E: Quer olhar de novo?

F: Sim.

E: Então vamos lá, eu te mostro de novo.

E. entrega o desenho a $\mathrm{F}$.

F: Aqui é a chaminé.

E: Isso.

F: Ah, pera aí, aqui é um vagão, aqui é outro.

E: Isso. Aí tem as rodas embaixo.

F: Tem o que?

E: As rodas em baixo.

F: Isso aqui é uma mistura de forma que eu não consigo desenhar desse jeito aqui.

E: Tudo bem, faz do jeito que você acha que tem que fazer. Se quiser fazer a obra circular inteira, tudo bem. Depois a gente vai trabalhar melhor. 
F: E aqui?

E: Deixa eu ver. Ah essa é a pontinha do trem, pra indicar que é o primeiro vagão do maquinista.

F: Ah, entendi.

E: Então vai.

F. passa as mãos na folha e posteriormente inicia o desenho.

F: Bom, esse aqui eu vou modernizar.

E ri: Então vai.

F: Não, que aquele lá é a carvão, eu vou fazer um elétrico.

E: Vai lá, faz um elétrico aí, moderniza.

F. continua a desenhar.

F: Por que ele tem, não colocaram banco?

E: Porque é como se fosse o trem do lado de fora. Entendeu? O banco fica do lado de dentro né? Como você tá fora do trem, não dá pra perceber.

F. desenha durante minutos.

E: E aí o que que tá falando, F.?

F: Tá faltando, tá faltando a maioria dos vagões.

E: Quantos vagões você vai fazer?

F: Ah, já fiz dois. Faltam nove ainda.

E: Tá.

F: Demorou muito.

E: Por que? Tá cansado?

F: Não, só um pouco.

F. continua a desenhar.

F: Onde é que fica aquela pontinha do trem?

E: Aquela pontinha fica na parte da frente.

F: Ela fica embaixo né?

E: Isso, embaixo, na ponta.

F. continua a desenhar

E: Pronto?

F: Sim.

E: Essa parte de baixo que você fez são as rodas?

F: Sim, seis rodas.

E: As rodas vão lá pro lado direito agora.

Entrevistador vira a folha.

Fábio toca a folha.

E: Podemos fazer os outros desenhos?

F: Eu estou muito sem criatividade agora, vai ficar ruim.

E: Prefere que eu volte amanhã e terminamos?

F: Hummm, não vamos tentar mais um pouco. Qual é o próximo?

E: Pode ser a nuvem?

F: Tá bom. Desenha em silêncio.

F entrega o desenho: Qual o outro?

E: Tem certeza que quer continuar?

F: Quero sim, desenhar é legal. Só tô mais quieto pra me concentrar mais e ter mais criatividade.

E: Podemos fazer a girafa?

F: Dá aí.

$F$ desenha a girafa.

F: Agora dá o leão pra acaba os animais. 
E: Estou colocando a folha aqui.

$\mathrm{F}$ desenha o leão.

E: Agora só falta a montanha e a árvore.

F: Vou desenhar a montanha.

E coloca a folha.

$\mathrm{F}$ desenha. Ao terminar entrega a folha para E.

$\mathrm{E}$ coloca outra folha para $\mathrm{F}$ desenhar a árvore.

$\mathrm{F}$ desenha a árvore.

F: Viu, conseguimo acaba tudo!

E: Muito bom, muito obrigado hein, $F$.

F: De nada.

E: A gente continua na semana que vem. 


\section{Desenhos Pré-teste: Fábio}

\section{Girafa}

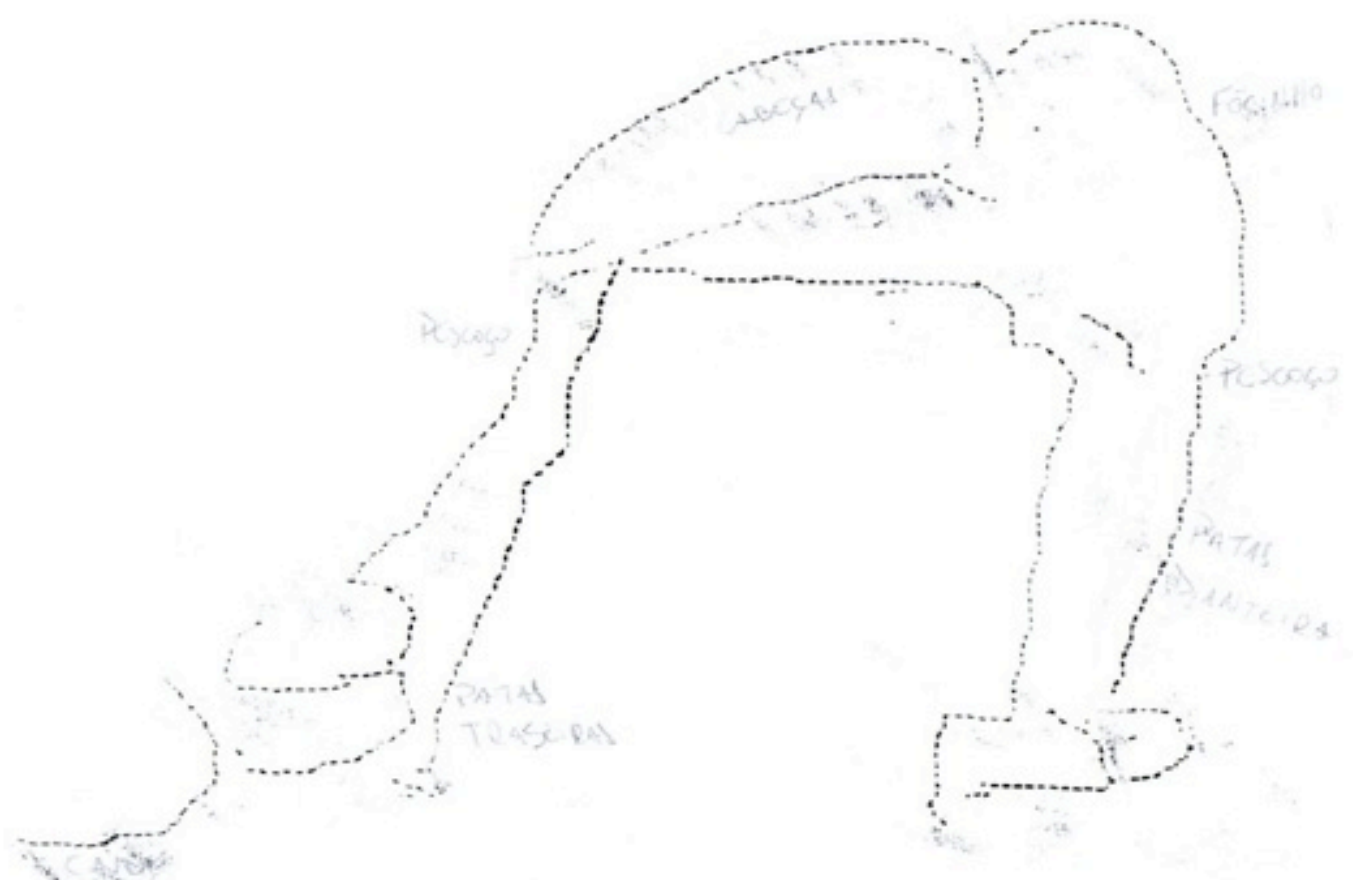

Nuvem

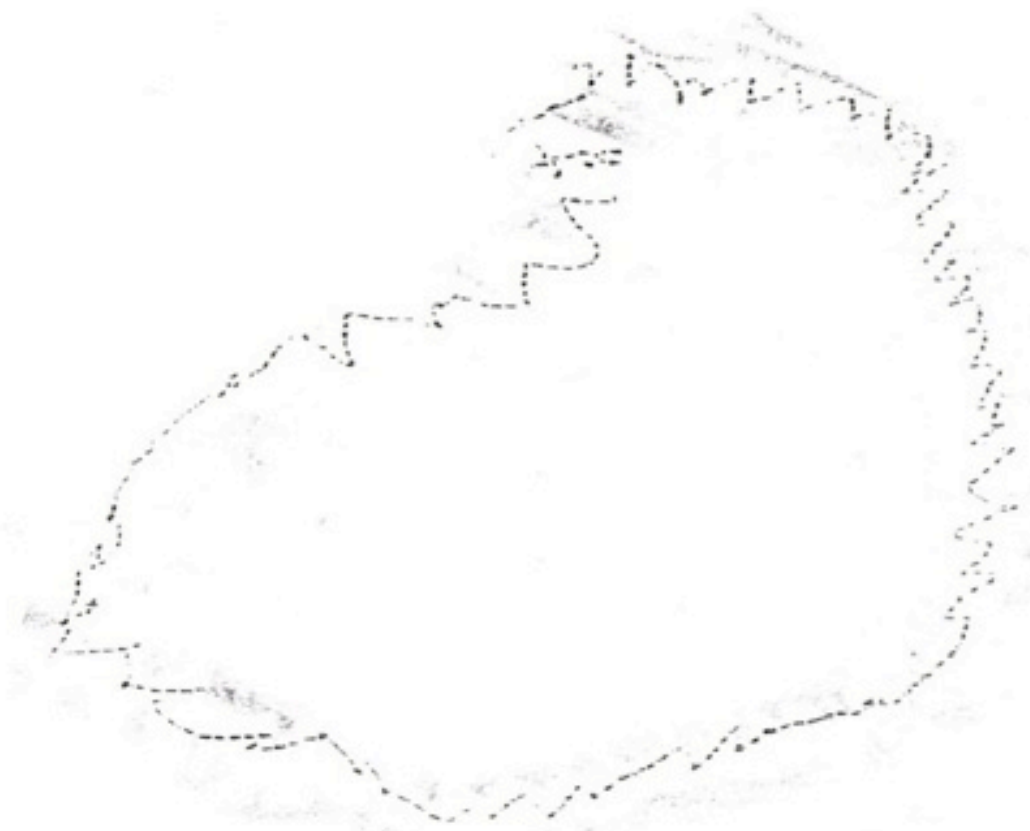


Montanha

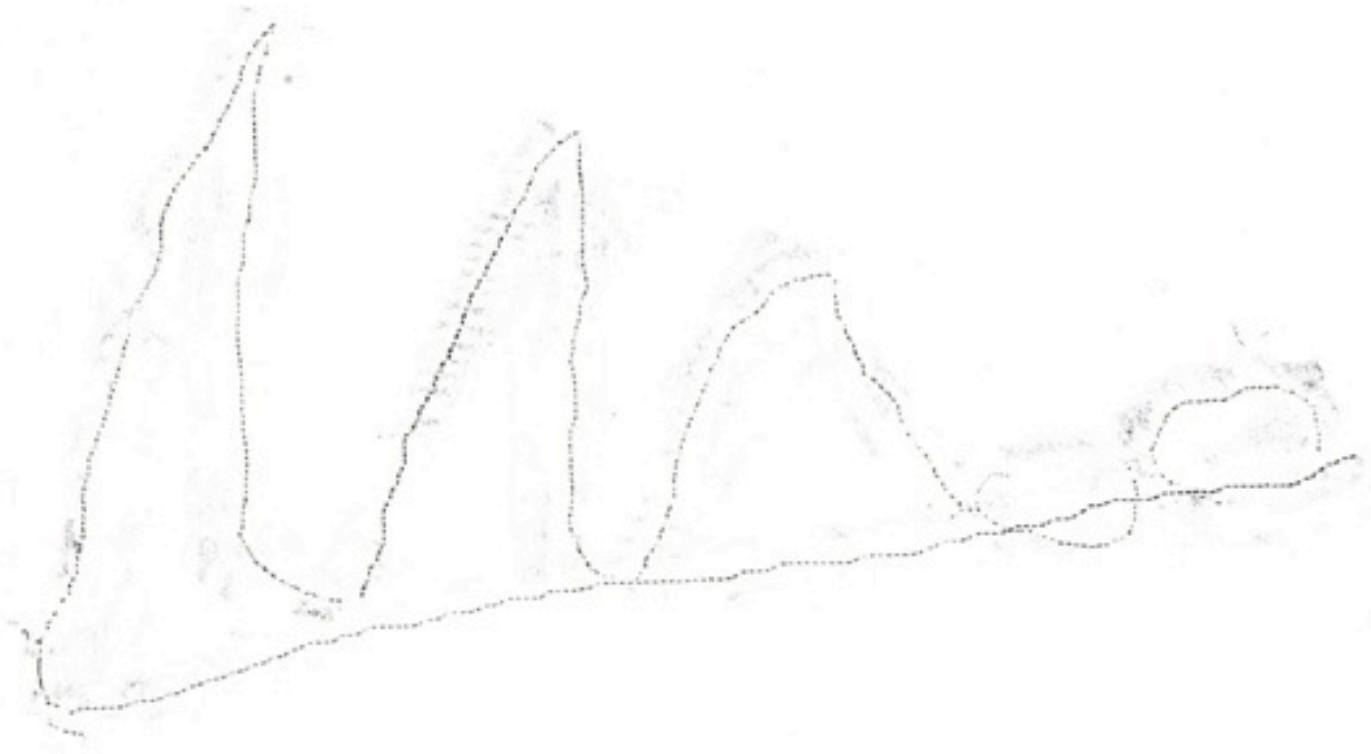

Árvore

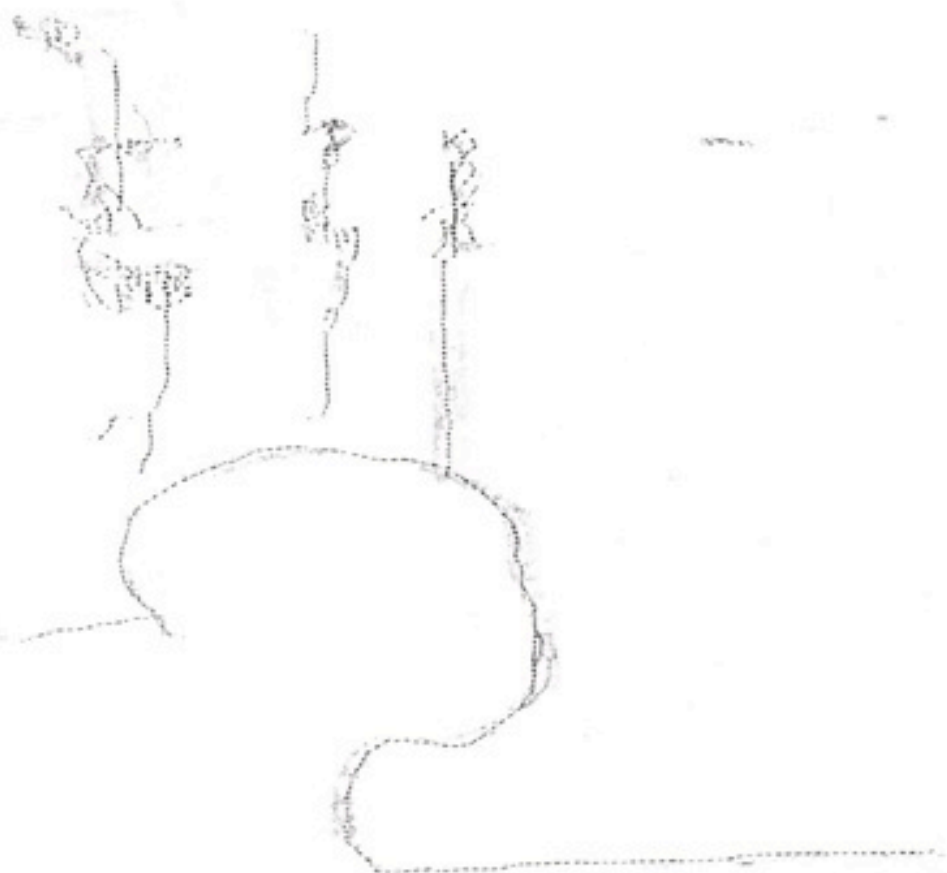


Trem

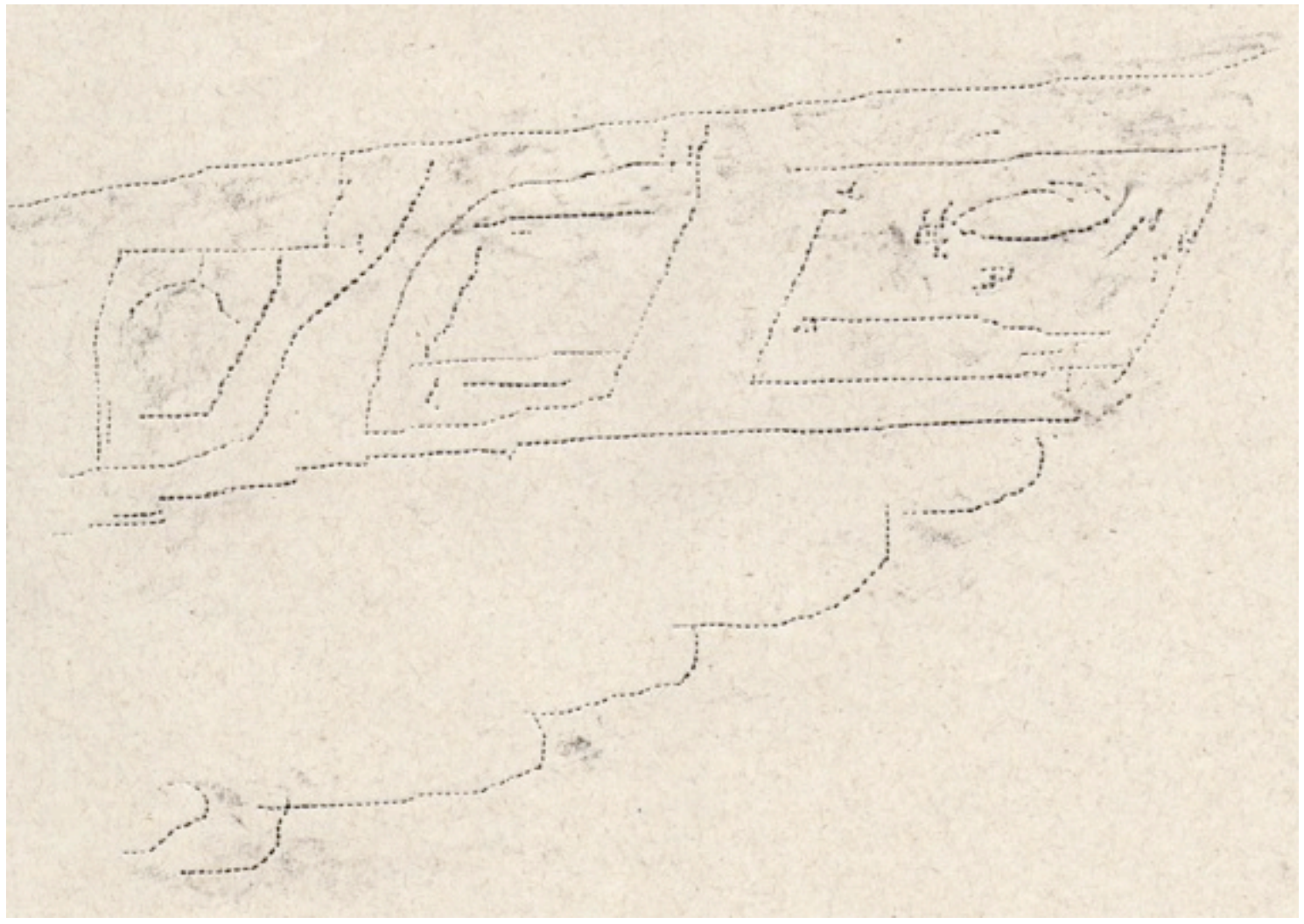

Leão

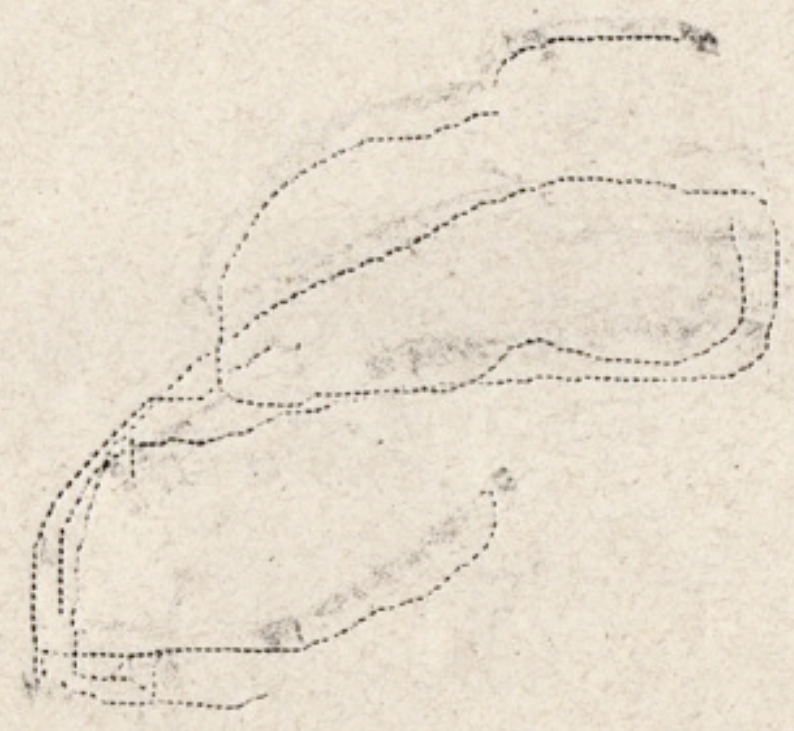




\section{Prédio}

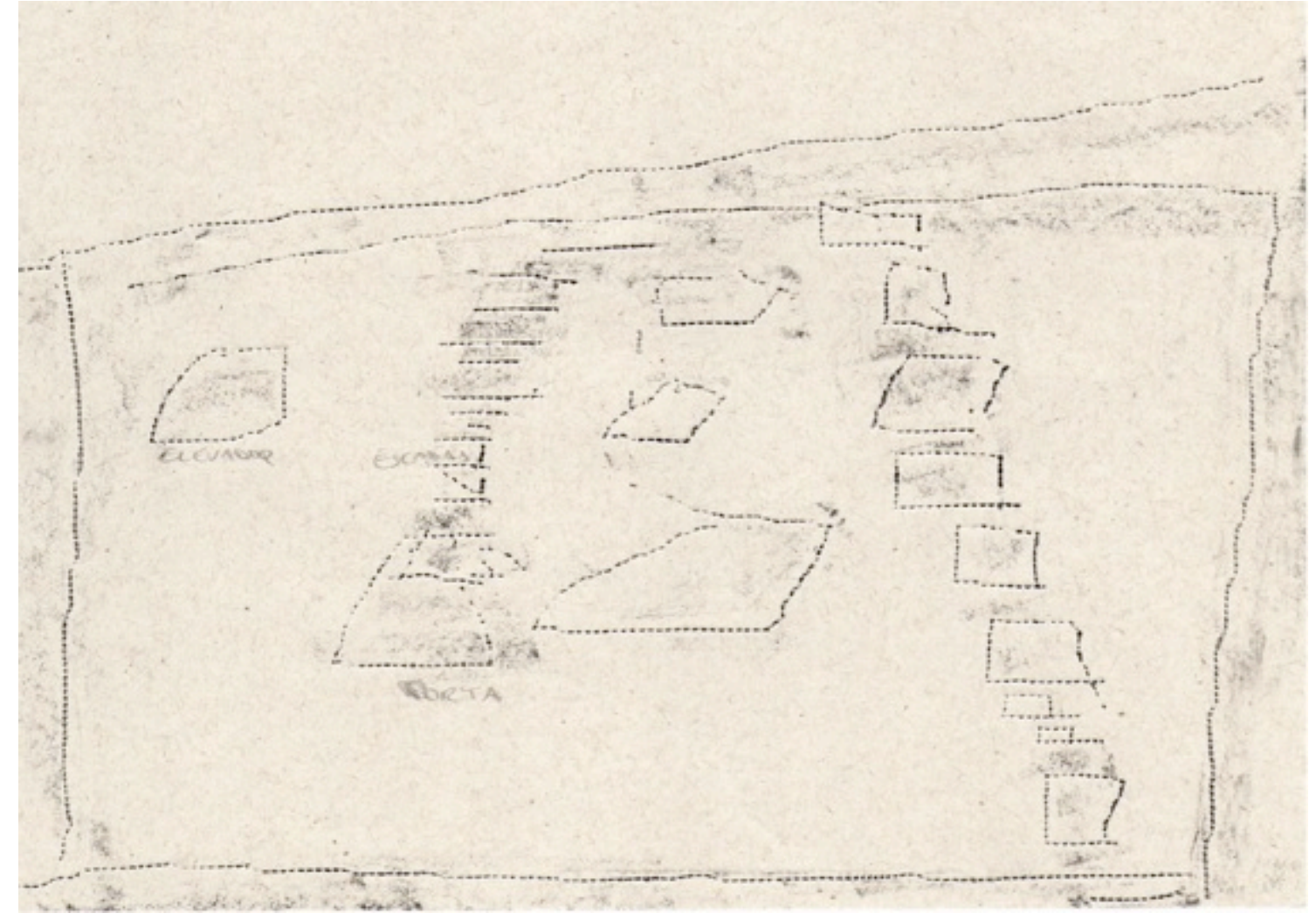

\section{Ilha}

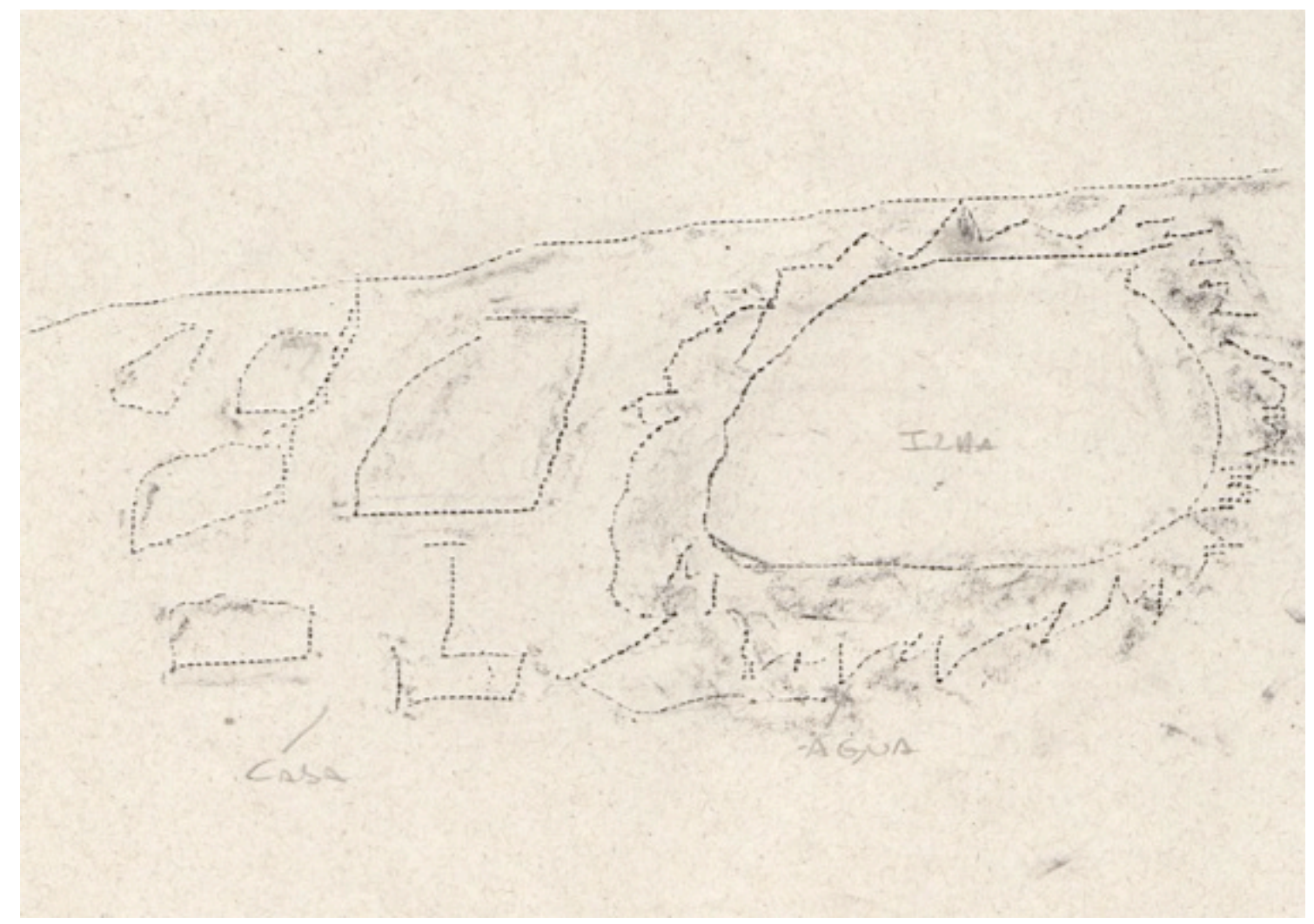




\section{Entrevista Pós-teste: Fábio}

F: Agora só falta eu no trabalho, ou você vai pegar mais alguém?

E: Não. Hoje é nosso último encontro, eu vou repetir pra você as perguntas que eu fiz na primeira vez, tá, perguntar se você conhece algumas coisas, e você me responde da forma que você entender ser a melhor, tá bom? Não fica preocupado em acertar ou errar, não é o objetivo, o objetivo é saber como que você pensa, o que você conhece a respeito dessas coisas, ainda mais depois do tempo que a gente passou, tá bom? Então vou fazer assim, vou fazer a pergunta, você responde verbalmente, e depois você desenha, certo? Então vamos lá. Você pode me dizer o que é girafa?

F: Girafa é um bicho, que é na floresta né, que ele vive, e ele, bom, ele é comprido, né, e tem o pescoço comprido.

E: Uhum. Que mais você sabe sobre a girafa?

F: (pausa) Ela não tem tromba não, né?

E: Não.

F: Não, ah tá. Não, é que eu confundi.

E: Confundiu com que?

F: Com elefante.

E: Ah! Você falou algumas características importantes dela. Você falou que ela tem o pescoço comprido...

F: Sim, isso.

E: Ela é um animal...

F: Que ela não é assim, não é... Como que fala... As pessoas não criam em residência, né?

E: Não criam residência?

F: Não, em residência não é comum.

$\mathrm{E}$ : Ah, ela não é doméstica.

F: É, não é doméstica.

E: Entendi. Como que chamam os animais que não são domésticos?

F: Florestais né?

E: É, florestais, selvagens, né.

F: É, tanto faz né, pode ser selvagem ou florestal, né.

E: Tá certo. Mais alguma coisa que você sabe sobre a girafa?

F: Que eu me lembro só isso.

E: O tamanho dela, ela é grande, ela é pequena...

F: Bom, eu sei que ela é comprida, né? Ela é enorme.

E: Então ela é alta?

F: É.

E: Tá legal. Você pode desenhar uma girafa pra mim? Com tudo isso que você me falou?

F inicia o desenho.

E: Quais são as partes dessa girafa que você tá desenhando?

F: O olho, cabeça, um olho aqui, o outro aqui, e isso aqui tudo é a cabeça e aqui é o focinho.

E: Você vai desenhar o resto do corpo?

F: Falta o pescoço.

F continua a desenhar.

F: Esqueci da boca.

E: E essa parte que você tá desenhando agora, o que é?

F: Agora, bom, agora é o resto do corpo.

E: Tá.

F: Prontinho.

E: Tá, só me explica agora, os olhos eu vi onde é, o nariz eu já vi, a boca... 
F: A boca eu num sei se tá no lugar certo.

E: Tá, é essa aí que você tá passando a mão?

F: É isso aqui, ó.

E: Tá.

F: É isso aqui, e isso aqui.

E: E o pescoço que você disse que tava fazendo?

F: O pescoço é aqui.

E: Tá.

F: E aqui é como se fosse o corpo. E aqui são as duas patas e aqui são as outras duas.

E: Tá legal. Pode virar aqui pra mim? Deixa eu te ajudar aqui. Tá legal, vamos pro próximo. Você pode me dizer o que é nuvem?

F: Nuvem é um... É um vapor né, que...

E: É o que?

F: Como se fala, é um... Não é um vapor, como que fala... É quando a... Sabe quando o... A água do rio quando tá no sol, né, ela evapora né, sobe e se transforma na nuvem, né, que ela vapor né, da água do rio, né.

$\mathrm{E}: \mathrm{E}$ que forma que a nuvem tem?

F: Ela é, bom ela é meio oval né. Ela... Ela quando... É, quando assim, quando tá chovendo ela, quando dá os trovões né, é quando ela se esbarra uma na outra né. As vezes pode até acho que dependendo pode acho que até formar uma descarga elétrica.

E: Tá. Quando bate uma na outra né?

F: Isso. Quando elas se trombam.

E: E o tamanho da nuvem, como é que você acha que é?

F: Acho que ela média.

E: Média? Tá certo. Mais alguma coisa que você lembra sobre as nuvens?

F: Não.

E: Você pode desenhar ela pra mim?

F inicia o desenho.

F: Pronto.

E: Pronto? Essa é a nuvem?

F: Isso.

E: Muito bom. Posso pegar? (pausa) Pode apertar aqui. Pode colocar outra folha.

F: Você tá fazendo o que mesmo?

E: Oi?

F: Você tá fazendo o que mesmo?

E: Como assim?

F: É... Se tá é... Como é que fala... Fazendo faculdade de que?

E: Eu sou psicólogo.

F: Ah é psicólogo né.

E: E to fazendo pós graduação em Psicologia.

F: Ah tá.

E: Vamos lá pro próximo? Quer que eu te ajude? Lembra que tem os dois pininhos de madeira aqui, ó, a folha tem que encostar nesses dois. Vamos lá, você pode e dizer o que é árvore?

F: Bom, obvio que é um ser vivo né.

E: Aham.

F: Que tem vida né, e... Árvore é, bom, ela é um ser vivo né, que ela é comprida também.

E: Ela é como?

F: Comprida.

E: Comprida... 
F: Ela... O tronco dela é meio encurvado né, e ela tem um galho né, que pode também ter... Pode ter folhas, né, nos galhos, né.

E: Aham.

F: E ela tem as raízes também né

E: Em que parte que ficam as raízes?

F: Que fica embaixo né, fica bem embaixo, fica no chão.

E: O tronco fica...

F: O tronco fica no meio e o galho fica lá em cima, fica bem em cima, no topo, né, da árvore.

E: Tá certo. E essa árvore é grande, é pequena...

F: Bom, eu já vi árvore um pouco... Um pouco assim, um pouco média assim, mas eu nunca vi uma árvore pequena. Geralmente a árvore é enorme também.

E: Legal, muito bom, você pode desenhar ela pra mim, com tudo isso que você falou? Você vai começar por onde? Por qual parte dela?

F: Ah eu vou acho que começar pela raiz né. Você viu no jornal que falou que os, jogos, que ta batendo em todo mundo...

E: Ah, ouvi falar sim, na Paulista, né?

F: Será que se estuda isso também? O porque que eles faz isso? Que tem gente que é classe média e faz uma besteira dessa.

E: Psicologia estuda sim.

F: Mas porque que eles faz isso?

E: Bom, isso a gente pode conversar depois, agora eu quero que você se concentre no seu desenho, pode ser?

F: Tá.

E: Te prometo que depois volto no assunto.

F: Tá.

E: Combinado? Tento te explicar.

F: Tá.

F inicia o desenho.

F: O galho pode ser reto né?

E: Faz do jeito que você achar melhor.

F: Tá.

F: Acabô.

E: Você pode me explicar quais são as partes dela?

F: Ela tem, árvore pode ter mais de três galhos né?

E: Você fez três?

F: Eu fiz três galhos aqui.

E: Aham, e isso que tá junto dos galhos?

F: Junto deles tem as folhas né

E: Uhum.

F: E tem... Esse aqui tem só no final, esse começa no meio, esse aqui começa quase no comecinho, tem folhas né, e aqui embaixo é a raiz, e aqui, isto daqui é o tronco da árvore.

E: Tá. Onde que é o tronco?

F: O tronco é aqui.

E: Ah! Tá. Beleza. Pode dar pra mim o desenho? Vamos para o próximo. Pode colocar essa folha aí. Vamos lá. Você pode me dizer o que é leão?

F: Bom, leão é um bicho né, que não é doméstico, selvagem né, e ele é um bicho feroz.

E: E como é que ele é?

F: Ele, ele é... Bom, ele tem focinho né, na cabeça, né, onde fica a cabeça. Só que, bom, na cabeça, né, onde fica a cabeça, é... A cabeça é coberta com, é, um cabelo assim, mas um cabelo que chama juba, e ela cobre o rosto todo do leão, né 
E: Uhum. Que mais você sabe sobre o leão? Como que é, você falou da cabeça e o resto do corpo dele, como é? Você sabe?

F: Bom, ele é enorme, né, também né

E: Ele é grande...

F: E o... Bom, o corpo dele, vamos dizer, ele, da parte de baixo é reto, né, tem o rabo também, né.

E: Uhum, que mais ela é igual?

F: E as patas né, de trás e as da frente.

E: Você sabe quantas patas são?

F: Quatro, né. São quatro.

E: Certo. Mais alguma coisa que você lembre sobre eles?

F: Não.

E: Desenha um leão pra mim.

$F$ inicia o desenho.

E: E aí, como é que tá?

F: Bom, tô... Fiz uma juba, né, e a cabeça, e o rosto.

E: O corpo você vai fazer?

F: Vou.

F: Prontinho.

E: Posso pegar?

F: Uhum.

E: Vamos para o próximo. Você pode me dizer o que é montanha?

F: Montanha é um... Montanha é... Como é que fala, é um... Bom montanha é um, como é que fala, ela é feita de rocha, né, de rochas e ela é como se fosse um... Sabe prédio que vai subindo andar, só que ela num, num é um prédio. Ela, ela se você reparar, ela... Ela é tão alta que você não dá nem pra chegar nela, né.

E: Ela é feita de rocha e ela é muito alta. É isso que você quer dizer?

F: É, ela é muito alta.

E: Comparando com um prédio, que ela é muito alta?

F: Isso.

E: E que forma ela tem mais ou menos? Ela é redonda, quadrada, ela é comprida, mais fina... Você sabe me dizer?

F: Eu acho que ela é... Bom, ela é meio inclinada, né.

E: Inclinada.

F: Não sei se é isso, mas acho que ela é meio, acho que ela é inclinada, né, porque se comparar com o vulcão só muda meio que tem a cratera né, o vulcão é meio inclinado também, só que tem cratera, e a montanha não.

E: Ah tá, essa é a diferença.

F: É.

E: Entendi. Muito bom. Você pode desenhar?

F inicia o desenho.

F: Eu lembro que ela é alguma coisa feita de rocha, só que eu num lembro o que que ela é.

E: Feito do que?

F: Eu sei que ela é feita de rocha, mas o que é mesmo...

E: Acho que tá boa sua definição.

F: Oi?

$\mathrm{E}$ : Eu entendi o que você quis dizer. (pausa) Isso que você fez o que que é?

F: Bom, acho que montanha é mais ou menos isso. É... Ela é reta aqui, eu não sei fazer a inclinação.

E: Tenta. Faz do jeito que você achar que é. 
F continua o desenho.

E: O que é isso que você ta fazendo agora?

F: Então, não é só uma montanha, são várias.

E: Ah, você ta desenhando várias? Cada traçado é uma montanha, é isso?

F: É.

E: Tá.

F: Pronto. Deu mais ou menos seis. Tem umas que são menores e as outras, outras grandes.

E: Tudo bem, dá o desenho pra mim? Agora você pode me dizer o que é prédio?

F: Bom, como que eu posso dizer, se for comparar ele do apartamento, ele é mais alto né, porque no mínimo ele tem o que, pra ser um prédio mesmo tem que ter oito, oito, nove,dez andares. Apartamento tem o que, um, dois, até acho que cinco né, prédio tem acho que mais de doze, treze andares. Acho que no mínimo oito.

E: Você ta me falando do prédio... Prédio tem que ter doze andares o apartamento tem que ter andar também, é isso?

F: Acho que apartamento, acho que é do um, acho que até cinco, seis andares, né.

E: Então se tiver cinco andares é apartamento?

F: Bom, pra ser um prédio mesmo...

E: Tenta explicar melhor o que é um prédio.

F: Edifício, né, é um edifício né.

E: Edifício. Ele é feito do que? Que formato ele tem?

F: Bom, ele é feito de... De... Ele é feito de que? De madeira não, de... É como uma casa, que é feito de tijolo né. Que...

E: Mas é igual uma casa?

F: Não.

E: Qual é a diferença?

F: Que a casa não tem andar, né? A casa é térrea, né?

E: Uhum. E os andares do prédio são compostos pelo que? Cada andar do prédio tem o que? Pra que que serve um prédio?

F: Bom, um prédio serve, por exemplo... Por exemplo, se eu comprar, se eu falar de uma faculdade né, faculdade não vai ter assim, faculdade é grande, não tem como ser uma escola simples, de dois, três andares. Faculdade tem que ter o que... Tem que ter mais de dez andares. Por exemplo... Um prédio serve pra que... Pra... O prédio serve pra... Um prédio serve pras coisas grandes né que nem faculdade.

E: Um prédio serve só pra faculdade?

F: Não, pra...

E: Pra que mais serve um prédio?

F: Pra... Que mais... Pra... (pausa) Bom, é pra... Hospital por exemplo né, um hospital grande assim né, pra um grande número de pessoas né, que vão nesse hospital né

E: Tá certo. Pode tentar desenhar um prédio pra eu ver?

F: Uhum. É meio inclinado né

E: Inclinado? Igual montanha?

F: Não, cada andar por exemplo é um quadrado.

E: Entendi, tá legal. Desenha imaginando o que você achar que é.

F: Ah tá, só uma coisa. Se você tiver um elevador é um prédio, se não tiver elevador com certeza não.

E: Não tem prédio sem elevador?

F: Prédio sem elevador?

E: É.

F: Acho que é impossível né, porque prédio tem muitos andares.

E: Legal, então desenha esse prédio aí. 
F: Eu não sei definir muito bem as coisas, né?

E: Oi?

F: Eu não sei definir muito bem as coisas, né?

E: Você faz do jeito que você achar. Não tem problema. Aí você vai me explicando no desenho.

F: Não sei, acho que não sei definir muito bem as coisas.

E: Por que você acha isso?

F: Ah, porque tem coisa que precisa muita palavra pra explicar né. E eu acho que não tenho muita palavra pra explicar tal coisa. Eu falo do jeito que eu acho.

E: Ah mas eu acho que tá bom. Você não acha?

F: Uhum.

E: Eu entendo o que você tá falando.

F continua o desenho.

E: Esses quadrados que você tá desenhando representam o que?

F: Representam os andares.

E: Ah tá, tá bom.

E: E aí, pronto?

F: (pausa) Prontinho.

E: Legal. Posso pegar?

F: Aqui são os andares, aqui é o elevador e aqui a porta da saída do prédio.

E: Tá legal. Vamos lá pro próximo então. Você pode me dizer o que é trem?

F: Bom, um trem é um meio de transporte que... Obviamente maior que o carro, né, que ônibus, e ele... É... Ele era movido a carvão, mas agora, sendo assim são movidos a eletricidade né, que ele se locomove é... Pelos trilhos né.

E: Uhum. E como que é o trem?

F: Bom, ele é bem bem bem comprido e os vagões são como se fosse... São quadrados mais ou menos, geralmente tem três vagões né. E... E também eles, né... tem aviso, tem a campainha, ah tem tudo os negocio que o trem tem né.

E: Tá ótimo, vamos desenhar então o trem?

F: Uhum.

E: Deixa a folha assim mesmo ou você prefere colocar na horizontal, já que você disse que ele é comprido.

F: Pode ser assim mesmo.

E: Assim mesmo dá?

F: Uhum.

E: Então vai lá, desenha um trem pra mim.

F: Ele tem o que... Umas nove rodas, por aí né.

E: Ele tem o que?

F: Ele tem o que... Umas nove rodas né, por aí.

E: Ah. Nove rodas? Depende do trem. O que que você acha?

F: Ah, acho que tem mais.

E: Mais?

F: Mais de nove. E ele também né... Ele não tem chaminé como os de antigamente né. Antigamente chamava Maria fumaça, né.

E: Uhum.

F: E... Tem diferença do trem da Maria fumaça, porque a Maria fumaça é à carvão, né?

E: É.

F: É a carvão, não é trem. Acho que passou a ser trem quando, acho que quando ele começou a ser movido a eletricidade né.

E: Muito bom. 
F: A diferença dele e o trem bala é que o trem bala não pára né, na estação, ele vai direto né.

E: É mesmo? Não sabia disso não.

F: Ou não? Acho que ele vai mais rápido, né, por isso. (pausa) Você já ouviu falar do trem bala, não né?

E: Já ouvi falar, mas eu sinceramente não sabia dessas coisas que você ta contando não. Não conhecia.

F: Não que ele não pare na estação, acho que ele, acho que ele é muito mais rápido que um trem normal.

E: Talvez por isso chame trem bala.

F: É.

E: Que parte é essa do trem que você tá desenhando?

$\mathrm{F}$ : Tem um aqui que ficou quase pra fora do trem.

E: Ah, nada mal hein?

F: Tô desenhando o primeiro vagão.

E: Tá.

F: Como não tem espaço, o vagão pode ser um do lado do outro também?

E: Não sei, acho que não vai ficar legal. Você quer outra folha?

F: Melhor.

E: Melhor né. Vou sugerir pra você virar a folha, porque aí você ganha mais espaço, entendeu?

F: É.

E: Poe a mão pra você ver a folha.

F: É, melhor ficar assim mesmo.

E: Então vai. Faz os trilhos... Os trilhos, não, os vagões do trem.

F inicia o desenho.

E: E aí, quantos vagões você já fez?

F: Ainda... Vixi, falta ainda... Dois... Só fiz um.

E: Que que é isso que você ta fazendo dentro do vagões?

F: Um banco. São os bancos.

E: Ah tá.

E: E aí, pronto?

F: Pronto.

E: Fez tudo?

F: Bom, aqui é o vagão do motorista e aqui, esses dois vagões são dos passageiros. Ah só falta uma coisinha...

E: O que?

F: Esqueci das rodas.

E: Então faz.

F continua o desenho.

E: Pronto?

F: Pronto.

E: Posso pegar?

F: Uhum.

E: Beleza. Vamos para o último. Você pode me dizer o que é ilha?

F: Bom, ilha é uma porção de terras cercada de água, né. Como por exemplo o Japão né, o Japão é uma, uma ilha, né, o Japão fica numa ilha.

E: Que mais você sabe sobre a ilha? Ela é terra, que você falou, cercada...

F: Bom, ela é terra cercada de água, né.

E: Aham. Tem algum ponto dela que não tem água na ilha? Que não é cercado de água?

F: Que eu me lembre não. 
E: De todos os lados.

F: É. Eu sei que tem ilhas que são vazias, né, tem ilhas que... Não sei né, acho que tem ilhas que tem gente que mora né , na ilha né, tem ilha que tem moradores, tem ilha que é vazia né. E: Muito bem. Você pode desenhar então pra mim uma ilha?

F: Aham.

E: Quer manter a folha assim ou quer virar?

F: Pode ser assim.

E: Quer manter assim?

F: É.

E: Então vai.

F inicia o desenho.

F: Ela é meio oval né.

E: Pode ser.

F: Oi?

E: Pode ser sim.

F: Ah tá.

E: Você vai desenhar um ilha oval?

F: É.

E: Tá ótimo.

F continua o desenho.

E: Esse risco que você tá fazendo representa o que?

F: Ah... Acho que eu já acabei. É o oceano.

E: O oceano. E a ilha ta...

F: A ilha tá... Aqui.

E: Essa é a ilha.

F: Aqui.

E: Tudo o que tá em volta é oceano, é isso?

F: É.

E: Tá ótimo. Ah, você fez tipo ondas né?

F: Isso.

E: Tá ótimo então. É isso, muito obrigado por sua paciência, sua ajuda...

F: Prazer em conhecer também.

E: Prazer foi meu. Gostou de trabalhar com desenho?

F: Foi legal.

E: Legal, né? Muito bom. Valeu! 
Desenhos Pós-teste: Fábio

Girafa
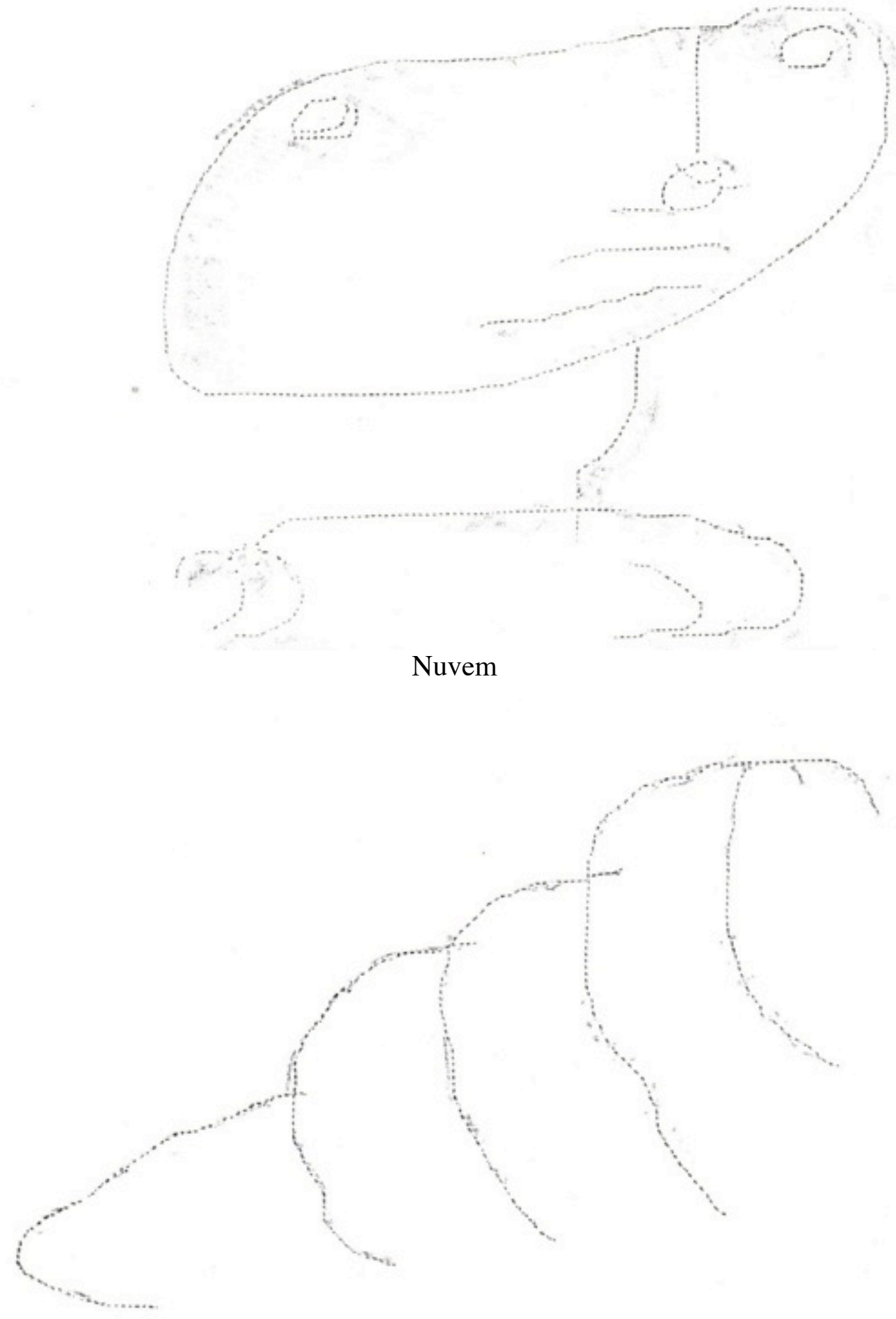
Montanha
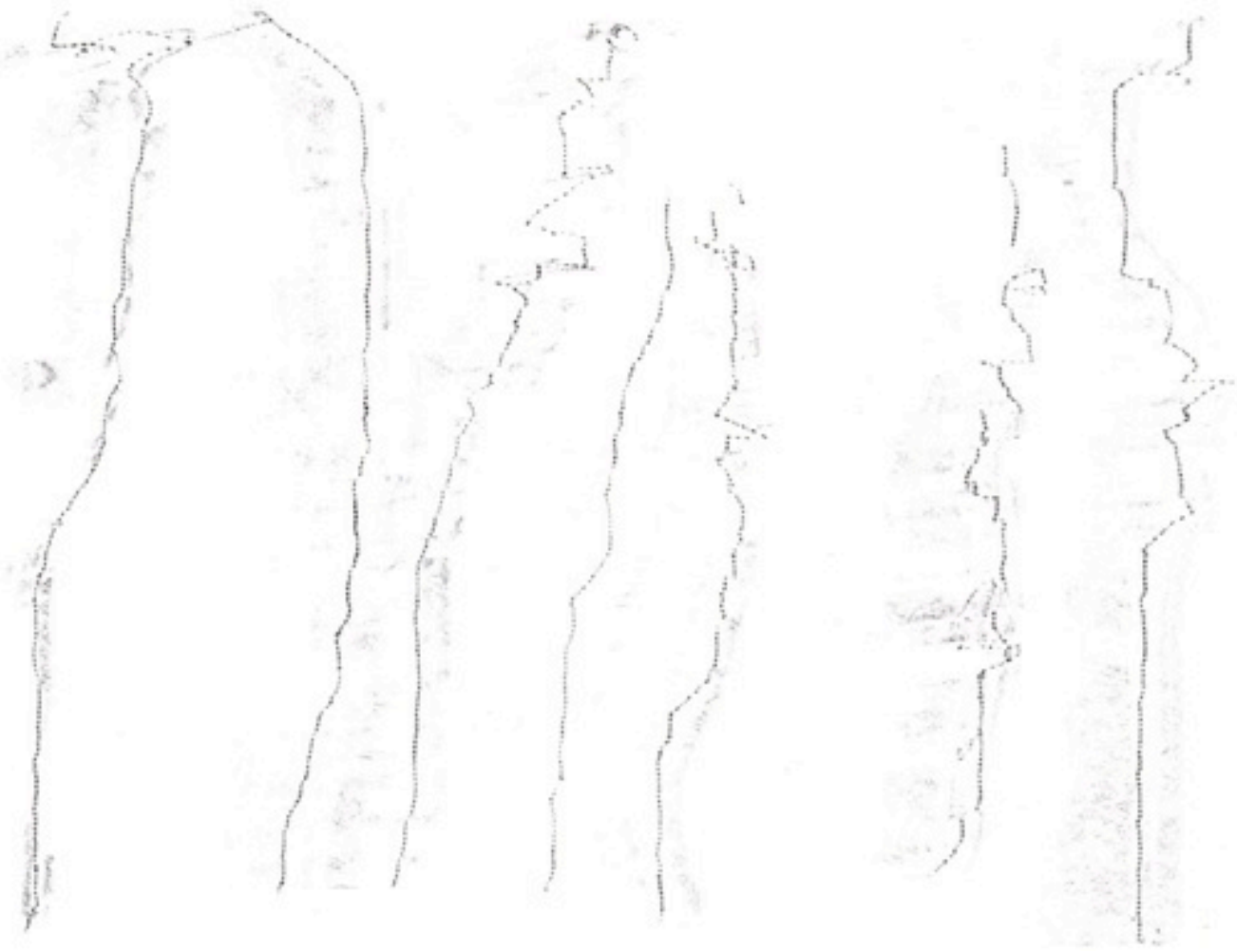

Árvore

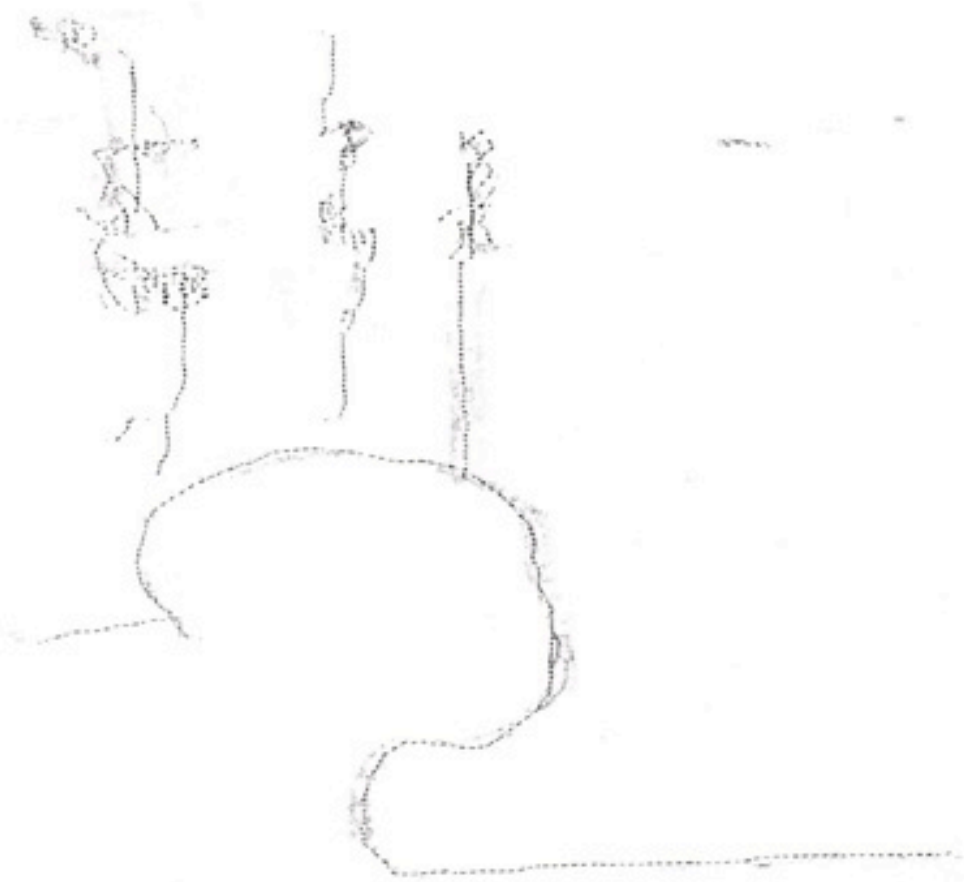


Trem

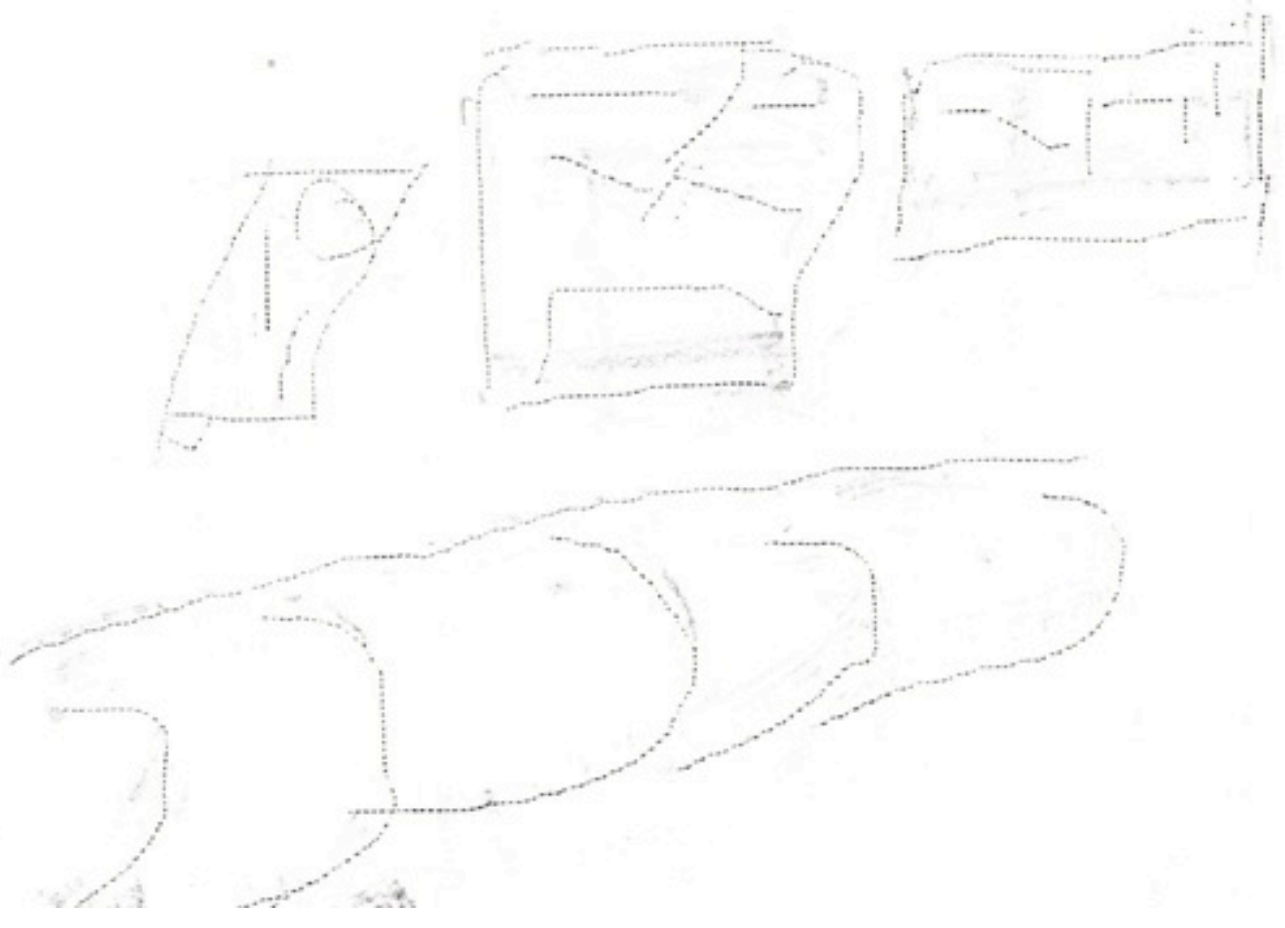

Leão
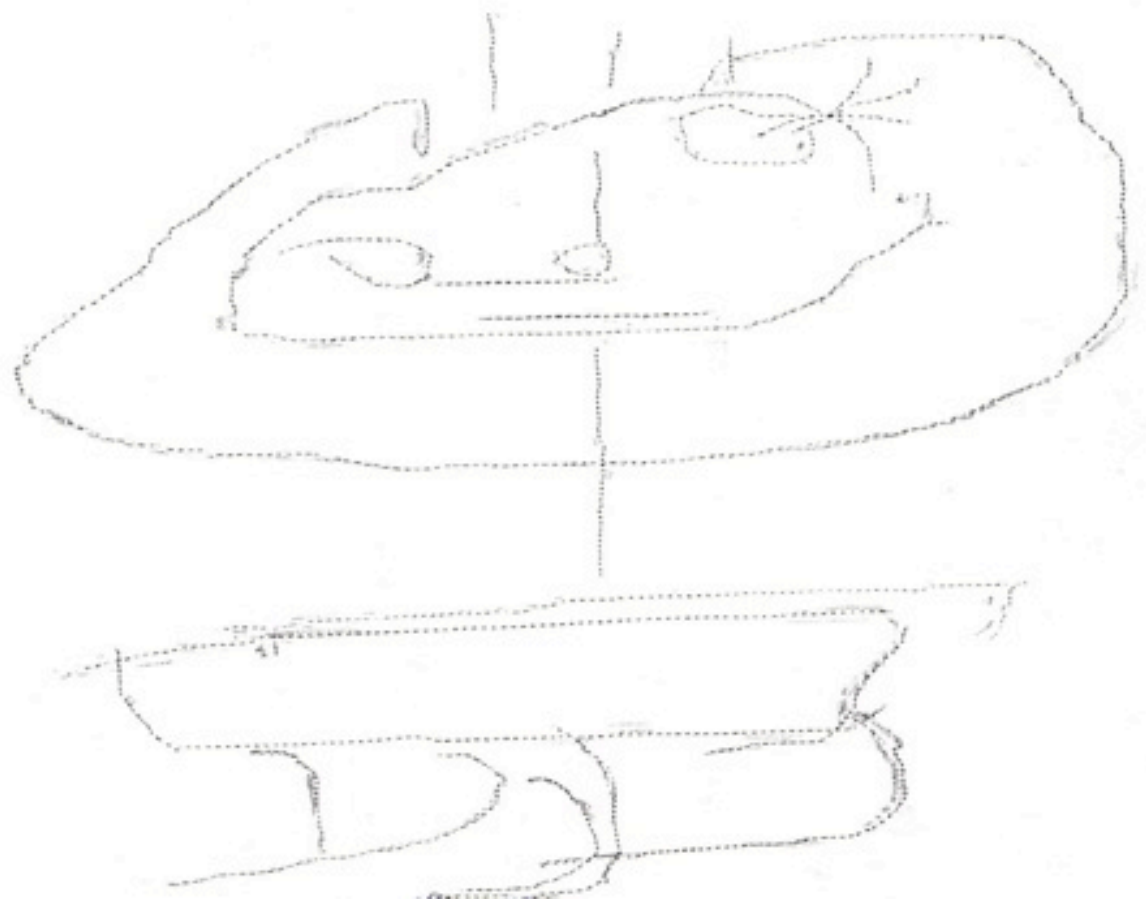
Prédio

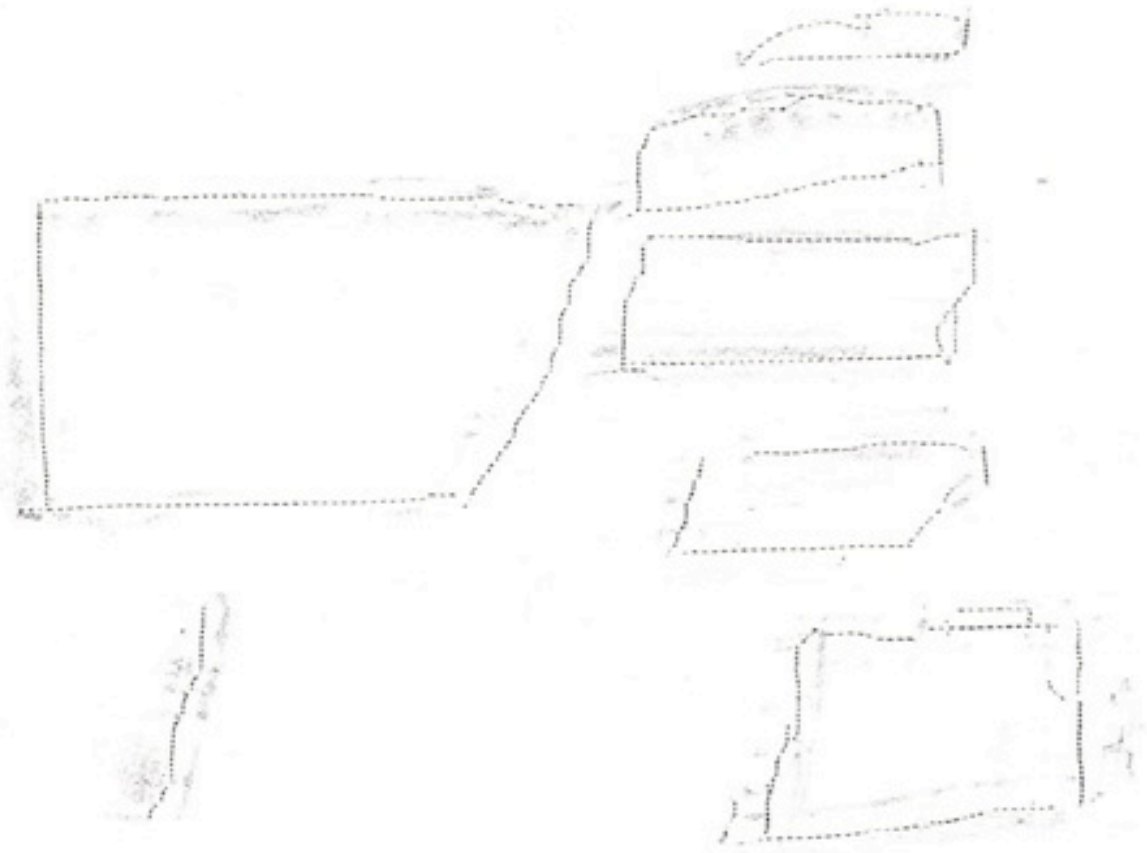

Ilha

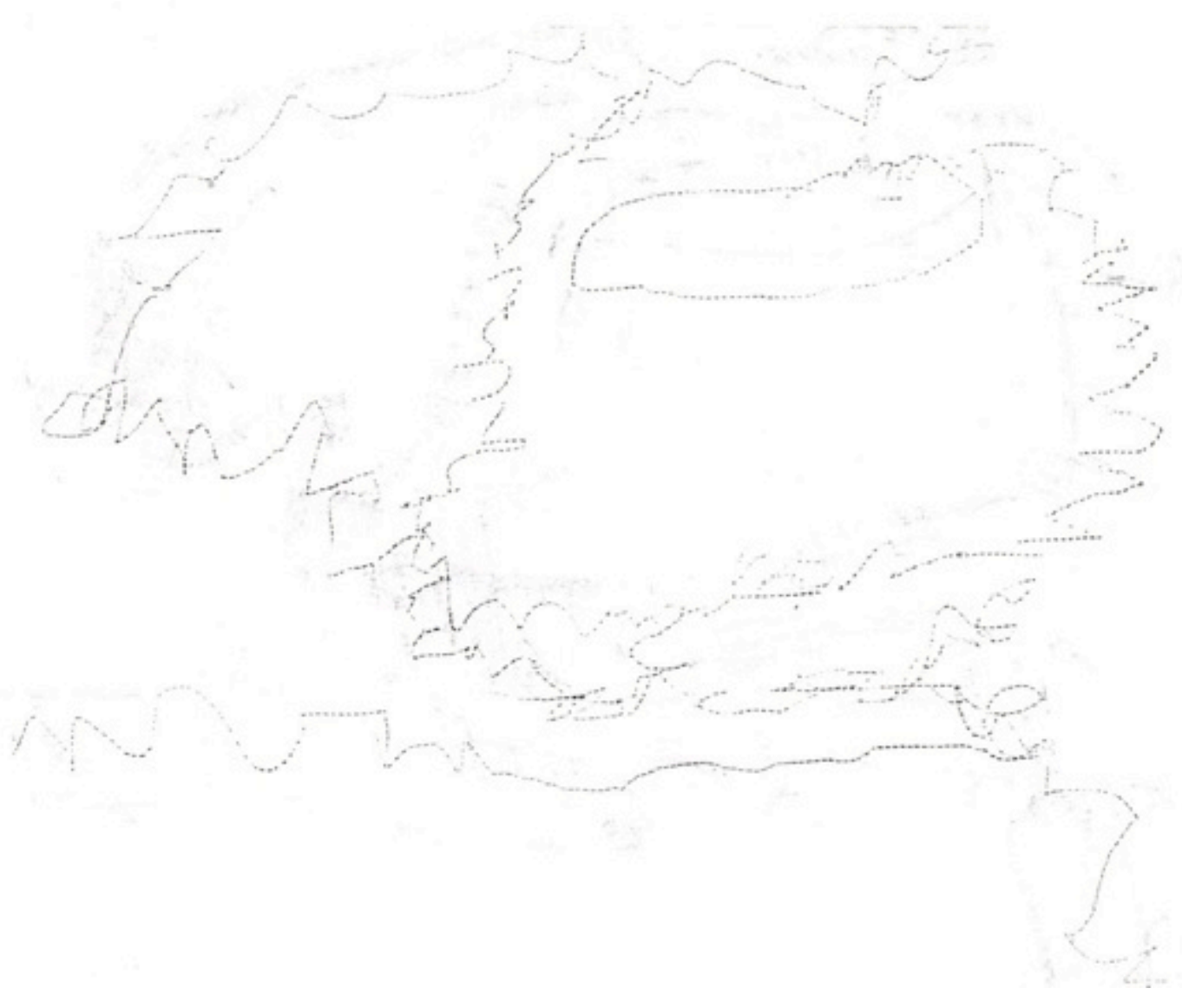


ANEXO E

MODELO DE TABELA PARA AVALIAÇÃO DOS JUÍZES

Folha 1

CONCEITO

\begin{tabular}{|c|c|c|c|c|}
\hline Sujeito & $\begin{array}{c}\text { Definição } \\
\text { verbal }\end{array}$ & Observações & Desenho & Observações \\
\hline N1.GH & & & & \\
\hline S1.MP & & & & \\
\hline N1-VC & & & & \\
\hline S1-XS & & & & \\
\hline H1.UL & & & & \\
\hline
\end{tabular}

Critérios de avaliação: 1- muito ruim; 2- ruim; 3-regular; 4- bom e 5- muito bom. 
Folha 2

CONCEITO

\begin{tabular}{|c|c|c|c|c|}
\hline Sujeito & $\begin{array}{c}\text { Definição } \\
\text { verbal }\end{array}$ & Observações & Desenho & Observações \\
\hline H1-SA & & & & \\
\hline E2-AI & & & & \\
\hline E2.DF & & & & \\
\hline O1.BT & & & & \\
\hline O1-GR & & & & \\
\hline
\end{tabular}

Critérios de avaliação: 1- muito ruim; 2- ruim; 3-regular; 4- bom e 5- muito bom. 
ANEXO F

TABULAÇÃO DE NOTAS ATRIBUÍDAS POR CADA JUIZ

Sujeito: Vítor (9 anos)

\section{Girafa}

Definição Verbal

\begin{tabular}{ccccc} 
& Pré teste & Observações & Pós teste & Observações \\
\hline Juiz 1 & 5 & & 5 & \\
Juiz 2 & 5 & & 4 & \\
Juiz 3 & 5 & Atributos definidores muito bem estabelecidos. & 5 & \\
\hline Média & 5 & & 4,6 & \\
\hline
\end{tabular}

Girafa

Desenho

\begin{tabular}{lcccc} 
& Pré teste & Observações & Pós teste & Observações \\
\hline Juiz 1 & 5 & 5 & \\
Juiz 2 & 5 & 5 & \\
Juiz 3 & 4 & 5 & \\
\hline Média & 4,6 & 5 & \\
\hline
\end{tabular}

Nuvem

Definição Verbal

\begin{tabular}{ccccc} 
& Pré teste & Observações & Pós teste & Observações \\
\hline Juiz 1 & 4 & 5 \\
Juiz 2 & 3 & 4 & \\
Juiz 3 & 5 & 5 & \\
\hline Média & 4 & 4,6 & \\
\hline
\end{tabular}

\begin{tabular}{ccccc}
\hline & & Nuvem & Desenho & \\
& & & \\
& Pré teste & Observações & Pós teste & Observações \\
\hline Juiz 1 & 5 & & 5 & \\
Juiz 2 & 3 & 3 & \\
Juiz 3 & 5 & 5 & \\
\hline Média & 4,3 & 4,3 & \\
\hline
\end{tabular}




\begin{tabular}{|c|c|c|c|c|}
\hline \multicolumn{5}{|c|}{$\begin{array}{c}\text { Montanha } \\
\text { Definição Verbal }\end{array}$} \\
\hline & Pré teste & Observações & Pós teste & Observações \\
\hline Juiz 1 & 5 & & 5 & \\
\hline Juiz 2 & 3 & & 4 & \\
\hline Juiz 3 & 5 & & 5 & \\
\hline Média & 4,3 & & 4,6 & \\
\hline
\end{tabular}

\section{Montanha \\ Desenho}

\begin{tabular}{|c|c|c|c|c|}
\hline & Pré teste & Observações & Pós teste & Observações \\
\hline Juiz 1 & 5 & & 5 & \\
\hline Juiz 2 & 5 & & 5 & \\
\hline Juiz 3 & 5 & & 5 & \\
\hline Média & 5 & & 5 & \\
\hline
\end{tabular}

\begin{tabular}{|c|c|c|c|c|}
\hline \multicolumn{5}{|c|}{$\begin{array}{c}\text { Árvore } \\
\text { Definição Verbal }\end{array}$} \\
\hline & Pré teste & Observações & Pós teste & Observações \\
\hline Juiz 1 & 5 & & 5 & \\
\hline Juiz 2 & 4 & & 3 & \\
\hline Juiz 3 & 5 & & 5 & \\
\hline Média & 4,6 & & 4,3 & \\
\hline
\end{tabular}

\begin{tabular}{|c|c|c|c|c|}
\hline & & & & $\begin{array}{c}\text { Árvore } \\
\text { Desenho }\end{array}$ \\
\hline & $\begin{array}{l}\text { Pré } \\
\text { teste }\end{array}$ & Observações & $\begin{array}{l}\text { Pós } \\
\text { teste }\end{array}$ & Observações \\
\hline Juiz 1 & 5 & & 5 & $\begin{array}{l}\text { Acredito que tenha desenhado os animais que se referiu na } \\
\text { descrição verbal. }\end{array}$ \\
\hline Juiz 2 & 5 & & 3 & \\
\hline Juiz 3 & 5 & & 4 & \\
\hline Média & 5 & & 4 & \\
\hline
\end{tabular}


Trem

Definição Verbal

\begin{tabular}{ccccc} 
& $\begin{array}{c}\text { Pré } \\
\text { teste }\end{array}$ & $\begin{array}{c}\text { Observ } \\
\text { ações }\end{array}$ & $\begin{array}{c}\text { Pós } \\
\text { teste }\end{array}$ & Observações \\
\hline $\begin{array}{l}\text { Jui } \\
\text { z } 1\end{array}$ & 4 & 4 & \\
Jui & 3 & 3 & \\
z 2 & & 5 & Quando se refere ao buraco, pode estar pensando na plataforma do metrô, \\
Jui & 3 & em que há um buraco onde ficam os trilhos. \\
z 3 & & 4 & \\
\hline $\begin{array}{c}\text { Mé } \\
\text { dia }\end{array}$ & 3,3 & & & \\
\hline
\end{tabular}

\begin{tabular}{ccccc}
\hline & & Trem \\
& & & \\
& Desenho & & \\
& Pré teste & Observações & Pós teste & Observações \\
\hline Juiz 1 & 5 & & 5 & \\
Juiz 2 & 4 & 4 & \\
Juiz 3 & 4 & 5 & \\
\hline Média & 4,3 & 4,6 & \\
\hline
\end{tabular}

Leão

Definição Verbal

\begin{tabular}{ccccc} 
& Pré teste & Observações & Pós teste & Observações \\
\hline Juiz 1 & 4 & 5 & \\
Juiz 2 & 4 & 4 & \\
Juiz 3 & 5 & 4 & \\
\hline Média & 4,3 & 4,3 & \\
\hline
\end{tabular}

\section{Leão}

Desenho

\begin{tabular}{ccccc} 
& Pré teste & Observações & Pós teste & Observações \\
\hline Juiz 1 & 3 & 5 & \\
Juiz 2 & 3 & 3 & \\
Juiz 3 & 4 & 3 & 3,6 \\
\hline Média & 3,3 & & \\
\hline
\end{tabular}




\begin{tabular}{lcccc}
\hline & \multicolumn{4}{c}{$\begin{array}{c}\text { Prédio } \\
\text { Definição Verbal }\end{array}$} \\
& Pré teste & Observações & Pós teste & Observações \\
\hline Juiz 1 & 5 & & 5 & \\
Juiz 2 & 4 & 4 & \\
Juiz 3 & 5 & & 5 & \\
\hline Média & 4,6 & 4,6 & \\
\hline
\end{tabular}

\begin{tabular}{|c|c|c|c|c|}
\hline \multicolumn{5}{|c|}{$\begin{array}{c}\text { Prédio } \\
\text { Desenho }\end{array}$} \\
\hline & Pré teste & Observações & Pós teste & Observações \\
\hline Juiz 1 & 5 & & 5 & \\
\hline Juiz 2 & 4 & & 4 & \\
\hline Juiz 3 & 4 & & 5 & \\
\hline Média & 4,3 & & 4,6 & \\
\hline
\end{tabular}

\begin{tabular}{|c|c|c|c|c|}
\hline \multicolumn{5}{|c|}{$\begin{array}{c}\text { Ilha } \\
\text { Definição Verbal }\end{array}$} \\
\hline & Pré teste & Observações & Pós teste & Observações \\
\hline Juiz 1 & 4 & & 5 & \\
\hline Juiz 2 & 4 & & 4 & \\
\hline Juiz 3 & 3 & & 5 & \\
\hline Média & 3,6 & & 4,6 & \\
\hline \multicolumn{5}{|c|}{$\begin{array}{c}\text { Ilha } \\
\text { Desenho }\end{array}$} \\
\hline & Pré teste & Observações & Pós teste & Observações \\
\hline Juiz 1 & 5 & & 5 & \\
\hline Juiz 2 & 3 & & 4 & \\
\hline Juiz 3 & 1 & & 3 & \\
\hline Média & 3 & & 4 & \\
\hline
\end{tabular}


Sujeito: Bruno (15 anos)

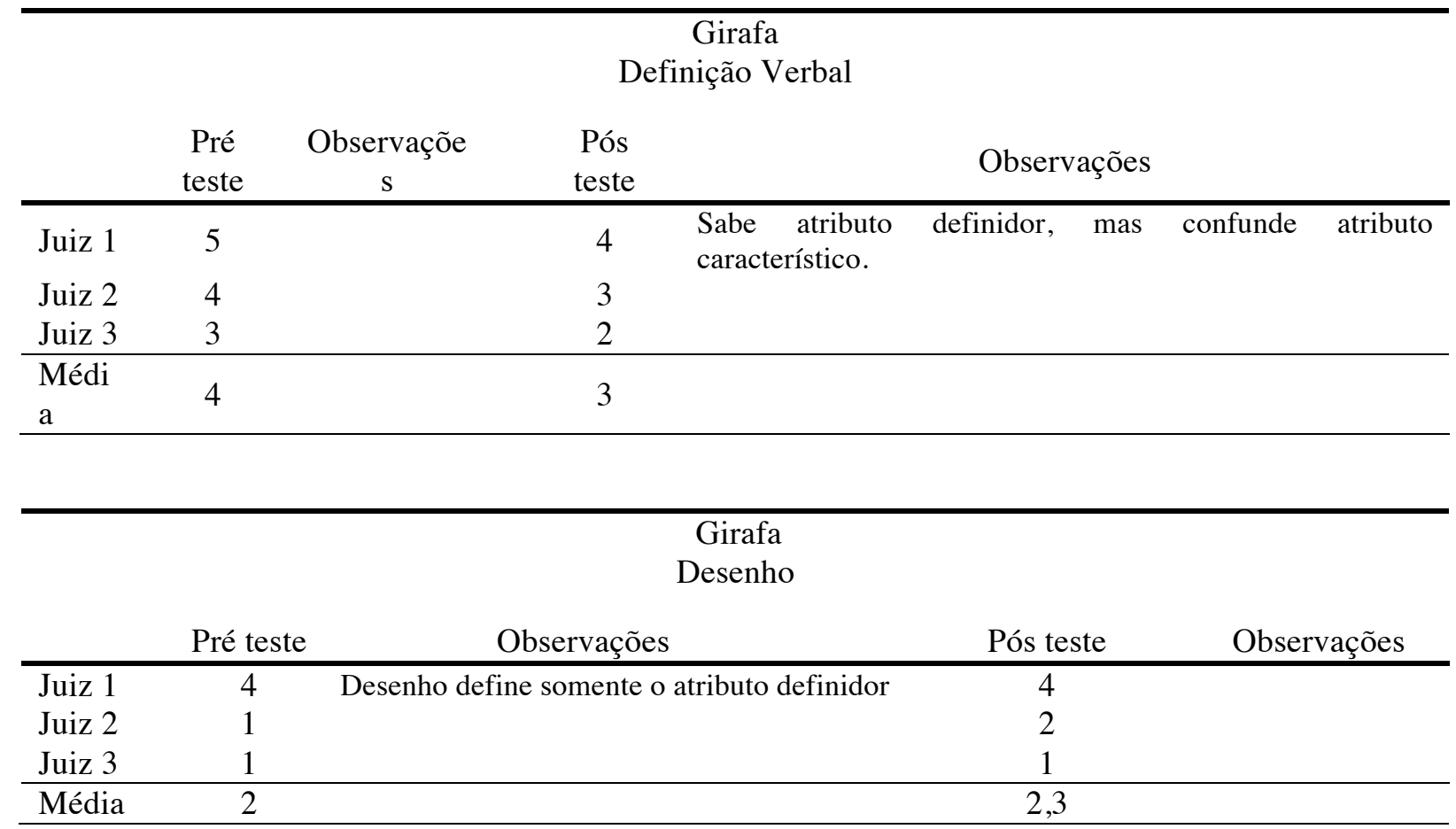

\section{Nuvem}

Definição Verbal

\begin{tabular}{|c|c|c|c|c|}
\hline & $\begin{array}{l}\text { Pré } \\
\text { teste }\end{array}$ & Observações & $\begin{array}{l}\text { Pós } \\
\text { teste }\end{array}$ & Observações \\
\hline $\begin{array}{l}\text { Jui } \\
\mathrm{z} 1\end{array}$ & 5 & & 5 & \\
\hline $\begin{array}{l}\text { Jui } \\
\text { z } 2\end{array}$ & 4 & & 3 & \\
\hline $\begin{array}{l}\text { Jui } \\
\text { z } 3\end{array}$ & 4 & $\begin{array}{l}\text { Tem o conceito, mas tem } \\
\text { problemas com o vocabulário. }\end{array}$ & 3 & $\begin{array}{l}\text { O processo da água está perfeito, mas deu a entender } \\
\text { que o sujeito acredita que a nuvem é um recipiente }\end{array}$ \\
\hline $\begin{array}{l}\text { Mé } \\
\text { dia }\end{array}$ & 4,3 & & 3,6 & \\
\hline
\end{tabular}

\section{Nuvem}

Desenho

\begin{tabular}{lcccc} 
& Pré teste & Observações & Pós teste & Observações \\
\hline Juiz 1 & 5 & 5 & \\
Juiz 2 & 3 & 2 \\
Juiz 3 & 4 & 4 & \\
\hline Média & 4 & 3,6 & \\
\hline
\end{tabular}




\begin{tabular}{|c|c|c|c|c|}
\hline \multicolumn{5}{|c|}{$\begin{array}{c}\text { Montanha } \\
\text { Definição Verbal }\end{array}$} \\
\hline & Pré teste & Observações & Pós teste & Observações \\
\hline Juiz 1 & 4 & & 5 & \\
\hline Juiz 2 & 3 & & 3 & \\
\hline Juiz 3 & 1 & & 2 & \\
\hline Média & 2,6 & & 3,3 & \\
\hline
\end{tabular}

\begin{tabular}{|c|c|c|c|c|}
\hline \multicolumn{5}{|c|}{$\begin{array}{l}\text { Montanha } \\
\text { Desenho }\end{array}$} \\
\hline & Pré teste & Observações & Pós teste & Observações \\
\hline Juiz 1 & 1 & & 2 & \\
\hline Juiz 2 & 2 & & 3 & \\
\hline Juiz 3 & 1 & & 1 & \\
\hline Média & 1,3 & & 2 & \\
\hline
\end{tabular}

\begin{tabular}{|c|c|c|c|c|}
\hline \multicolumn{5}{|c|}{$\begin{array}{c}\text { Árvore } \\
\text { Definição Verbal }\end{array}$} \\
\hline & Pré teste & Observações & Pós teste & Observações \\
\hline Juiz 1 & 3 & & 5 & \\
\hline Juiz 2 & 4 & & 4 & \\
\hline Juiz 3 & 5 & & 5 & \\
\hline Média & 4 & & 4,6 & \\
\hline
\end{tabular}

\begin{tabular}{lcccc}
\hline & & $\begin{array}{c}\text { Árvore } \\
\text { Desenho }\end{array}$ & \\
& Pré teste & Observações & Pós teste & Observações \\
\hline Juiz 1 & 5 & 2 & \\
Juiz 2 & 3 & 2 & \\
Juiz 3 & 5 & 2 & 2 & \\
\hline Média & 4,3 & & 2 & \\
\hline
\end{tabular}

Trem

Definição Verbal

\begin{tabular}{lcccc} 
& Pré teste & Observações & Pós teste & Observações \\
\hline Juiz 1 & 5 & Utiliza o olfato para identificação & 5 \\
Juiz 2 & 4 & & 4 \\
Juiz 3 & 5 & & 5 \\
\hline Média & 4,6 & & 4,6 \\
\hline
\end{tabular}




\begin{tabular}{|c|c|c|c|c|}
\hline \multicolumn{5}{|c|}{$\begin{array}{c}\text { Trem } \\
\text { Desenho }\end{array}$} \\
\hline & Pré teste & Observações & Pós teste & Observações \\
\hline Juiz 1 & 5 & & 5 & \\
\hline Juiz 2 & 3 & & 4 & \\
\hline Juiz 3 & 3 & & 3 & \\
\hline Média & 3,6 & & 4 & \\
\hline
\end{tabular}

Leão

Definição Verbal

\begin{tabular}{lcccc} 
& Pré teste & Observações & Pós teste & Observações \\
\hline Juiz 1 & 5 & 5 & \\
Juiz 2 & 4 & 3 \\
Juiz 3 & 5 & 5 & \\
\hline Média & 4,6 & 4,3 & \\
\hline
\end{tabular}

\section{Leão}

Desenho

\begin{tabular}{lcccc} 
& Pré teste & Observações & Pós teste & Observações \\
\hline Juiz 1 & 3 & & 3 \\
Juiz 2 & 2 & 2 & \\
Juiz 3 & 3 & & 2 \\
\hline Média & 2,6 & 2,3 & \\
\hline
\end{tabular}

Prédio

Definição Verbal

\begin{tabular}{lcccc} 
& Pré teste & Observações & Pós teste & Observações \\
\hline Juiz 1 & 5 & 5 & \\
Juiz 2 & 4 & 4 \\
Juiz 3 & 5 & 5 & \\
\hline Média & 4,6 & 4,6 & \\
\hline
\end{tabular}

\begin{tabular}{lcccc}
\hline & \multicolumn{2}{c}{$\begin{array}{c}\text { Prédio } \\
\text { Desenho }\end{array}$} \\
& Pré teste & Observações & Pós teste & Observações \\
\hline Juiz 1 & 5 & 2 & \\
Juiz 2 & 4 & 3 & \\
Juiz 3 & 3 & 2 & \\
\hline Média & 4 & & 2,3 & \\
\hline
\end{tabular}




\begin{tabular}{|c|c|c|c|c|c|}
\hline \multicolumn{6}{|c|}{$\begin{array}{c}\text { Ilha } \\
\text { Definição Verbal }\end{array}$} \\
\hline & Pré teste & Observações & Pós teste & \multicolumn{2}{|c|}{ Observações } \\
\hline Juiz 1 & 3 & & 4 & \multicolumn{2}{|c|}{ Sabe o que é, mas se confundiu com as palavras } \\
\hline Juiz 2 & \multicolumn{2}{|l|}{3} & 2 & & \\
\hline Juiz 3 & \multicolumn{2}{|l|}{2} & \multicolumn{3}{|l|}{2} \\
\hline Média & \multicolumn{2}{|l|}{2,6} & \multicolumn{3}{|l|}{2,6} \\
\hline \multicolumn{6}{|c|}{$\begin{array}{c}\text { Ilha } \\
\text { Desenho }\end{array}$} \\
\hline \multicolumn{3}{|c|}{ Pré teste } & Observações & Pós teste & Observações \\
\hline Juiz 1 & \multicolumn{2}{|c|}{1} & \multicolumn{3}{|c|}{1} \\
\hline Juiz 2 & \multicolumn{2}{|c|}{2} & \multirow{2}{*}{\multicolumn{3}{|c|}{$\begin{array}{l}2 \\
2\end{array}$}} \\
\hline Juiz 3 & \multicolumn{2}{|c|}{1} & & & \\
\hline Média & \multicolumn{2}{|c|}{1,3} & \multicolumn{3}{|c|}{1,6} \\
\hline
\end{tabular}

Sujeito: Daniela (12 anos)

\begin{tabular}{lrrrr}
\hline & \multicolumn{2}{c}{$\begin{array}{c}\text { Girafa } \\
\text { Definição Verbal }\end{array}$} \\
& Pré teste & Observações & Pós teste & Observações \\
\hline Juiz 1 & 2 & & 5 & \\
Juiz 2 & 2 & & 3 & \\
Juiz 3 & 1 & 2 & 2,3 \\
\hline Média & 1,6 & & \multicolumn{2}{c}{3,3} \\
\hline
\end{tabular}

\begin{tabular}{|c|c|c|c|c|}
\hline \multicolumn{5}{|c|}{$\begin{array}{c}\text { Girafa } \\
\text { Desenho }\end{array}$} \\
\hline & Pré teste & Observações & Pós teste & Observações \\
\hline Juiz 1 & \multicolumn{2}{|r|}{5} & 4 & \\
\hline Juiz 2 & \multicolumn{2}{|r|}{3} & 3 & \\
\hline Juiz 3 & \multicolumn{2}{|r|}{3} & 2 & \\
\hline Média & \multicolumn{2}{|c|}{3,6} & \multicolumn{2}{|c|}{3} \\
\hline \multicolumn{5}{|c|}{$\begin{array}{c}\text { Nuvem } \\
\text { Definição Verbal }\end{array}$} \\
\hline & Pré teste & Observações & Pós teste & Observações \\
\hline Juiz 1 & 3 & & 5 & \\
\hline Juiz 2 & 2 & & 3 & \\
\hline Juiz 3 & 1 & & 2 & \\
\hline Média & 2 & & 3,3 & \\
\hline
\end{tabular}


Nuvem

Desenho

\begin{tabular}{lrrrr} 
& Pré teste & Observações & Pós teste & Observações \\
\hline Juiz 1 & 4 & 5 & \\
Juiz 2 & 2 & 4 & \\
Juiz 3 & 3 & 5 & \\
\hline Média & 3 & 4,6 & \\
\hline
\end{tabular}

\begin{tabular}{|c|c|c|c|c|}
\hline \multicolumn{5}{|c|}{$\begin{array}{c}\text { Montanha } \\
\text { Definição Verbal }\end{array}$} \\
\hline & Pré teste & Observações & Pós teste & Observações \\
\hline Juiz 1 & 1 & Ele definiu o conceito montanha russa correto. & 1 & \\
\hline Juiz 2 & 1 & & 2 & \\
\hline Juiz 3 & 1 & & 1 & \\
\hline Média & 1 & & 1,3 & \\
\hline
\end{tabular}

\section{Montanha}

Desenho

\begin{tabular}{lrrrr} 
& Pré teste & Observações & Pós teste & Observações \\
\hline Juiz 1 & 5 & 1 & \\
Juiz 2 & 4 & 4 & \\
Juiz 3 & 2 & 5 & \\
\hline Média & 3,6 & 3,3 & \\
\hline
\end{tabular}

\begin{tabular}{|c|c|c|c|c|}
\hline \multicolumn{5}{|c|}{$\begin{array}{c}\text { Árvore } \\
\text { Definição Verbal }\end{array}$} \\
\hline & Pré teste & Observações & Pós teste & Observações \\
\hline Juiz 1 & 1 & & 4 & \\
\hline Juiz 2 & 2 & & 2 & \\
\hline Juiz 3 & 2 & Faltam os conceitos de "em cima" e "embaixo". & 3 & \\
\hline Média & 1,6 & & 3 & \\
\hline
\end{tabular}

\begin{tabular}{|c|c|c|c|c|}
\hline \multicolumn{5}{|c|}{$\begin{array}{c}\text { Árvore } \\
\text { Desenho }\end{array}$} \\
\hline & Pré teste & Observações & Pós teste & Observações \\
\hline Juiz 1 & 5 & & 4 & Tronco muito curto, parece mais flor. \\
\hline Juiz 2 & 3 & & 2 & \\
\hline Juiz 3 & 3 & & 3 & \\
\hline Média & 3,6 & & 3 & \\
\hline
\end{tabular}




\begin{tabular}{|c|c|c|c|c|}
\hline \multicolumn{5}{|c|}{$\begin{array}{c}\text { Trem } \\
\text { Definição Verbal }\end{array}$} \\
\hline & Pré teste & Observações & Pós teste & Observações \\
\hline Juiz 1 & & & & \\
\hline Juiz 2 & & & & \\
\hline Juiz 3 & & & & \\
\hline Média & & & & \\
\hline
\end{tabular}

\begin{tabular}{|c|c|c|c|c|}
\hline \multicolumn{5}{|c|}{$\begin{array}{c}\text { Trem } \\
\text { Desenho }\end{array}$} \\
\hline & Pré teste & Observações & Pós teste & Observações \\
\hline Juiz 1 & & & & \\
\hline Juiz 2 & & & & \\
\hline Juiz 3 & & & & \\
\hline Média & & & & \\
\hline
\end{tabular}

\begin{tabular}{|c|c|c|c|c|}
\hline \multicolumn{5}{|c|}{$\begin{array}{c}\text { Leão } \\
\text { Definição Verbal }\end{array}$} \\
\hline & Pré teste & Observações & Pós teste & Observações \\
\hline Juiz 1 & 1 & & & \\
\hline Juiz 2 & 1 & & & \\
\hline Juiz 3 & 1 & & & \\
\hline Média & 1 & & & \\
\hline
\end{tabular}

\begin{tabular}{lrrrr} 
& & \multicolumn{1}{c}{$\begin{array}{c}\text { Leão } \\
\text { Desenho }\end{array}$} & \\
& Pré teste & Observações & Pós teste & Observações \\
\hline Juiz 1 & 1 & & 1 & \\
Juiz 2 & 2 & 1 & \\
Juiz 3 & 1 & 2 & \\
\hline Média & 1,3 & 1,3 \\
\hline
\end{tabular}

\begin{tabular}{lrrrr}
\hline & \multicolumn{3}{c}{$\begin{array}{c}\text { Prédio } \\
\text { Definição Verbal }\end{array}$} \\
& Pré teste & Observações & Pós teste & Observações \\
\hline Juiz 1 & 4 & & 4 & \\
Juiz 2 & 3 & 3 & \\
Juiz 3 & 1 & 3 & 3,3 \\
\hline Média & 2,6 & & 3,3 \\
\hline
\end{tabular}




\begin{tabular}{|c|c|c|c|c|}
\hline \multicolumn{5}{|c|}{$\begin{array}{c}\text { Prédio } \\
\text { Desenho }\end{array}$} \\
\hline & Pré teste & Observações & Pós teste & Observações \\
\hline Juiz 1 & 5 & & & \\
\hline Juiz 2 & 2 & & & \\
\hline Juiz 3 & 3 & & & \\
\hline Média & 2 & & & \\
\hline
\end{tabular}

\begin{tabular}{|c|c|c|c|c|}
\hline \multicolumn{5}{|c|}{$\begin{array}{c}\text { Ilha } \\
\text { Definição Verbal }\end{array}$} \\
\hline & Pré teste & Observações & Pós teste & Observações \\
\hline Juiz 1 & & & & \\
\hline Juiz 2 & & & & \\
\hline Juiz 3 & & & & \\
\hline Média & & & & \\
\hline
\end{tabular}

Sujeito: Rogério (12 anos)

\begin{tabular}{lcccc}
\hline & \multicolumn{4}{c}{$\begin{array}{c}\text { Girafa } \\
\text { Definição Verbal }\end{array}$} \\
& Pré teste & Observações & Pós teste & Observações \\
\hline Juiz 1 & 5 & & 4 & \\
Juiz 2 & 3 & 4 & \\
Juiz 3 & 2 & & 2 & \\
\hline Média & 3,3 & 3,3 & \\
\hline
\end{tabular}

\section{Girafa}

Desenho

\begin{tabular}{lcccc} 
& Pré teste & Observações & Pós teste & Observações \\
\hline Juiz 1 & 5 & 4 & \\
Juiz 2 & 3 & 4 & \\
Juiz 3 & 3 & 3,3 & \\
\hline Média & 3,6 & 3,3 & \\
\hline
\end{tabular}

\begin{tabular}{lcccc}
\hline & & $\begin{array}{c}\text { Nuvem } \\
\text { Definição Verbal }\end{array}$ & \\
& Pré teste & Observações & Pós teste & Observações \\
\hline Juiz 1 & 4 & & 5 & \\
Juiz 2 & 3 & & 4 & \\
Juiz 3 & 3 & 3 & \\
\hline Média & 3,3 & 4 \\
\hline
\end{tabular}




\begin{tabular}{lcccc}
\hline & & Nuvem \\
& Desenho & \\
& Pré teste & Observações & Pós teste & Observações \\
\hline Juiz 1 & 2 & 5 & \\
Juiz 2 & 2 & 4 & \\
Juiz 3 & 3 & 3 & \\
\hline Média & 2,3 & & 4 & \\
\hline
\end{tabular}

\begin{tabular}{|c|c|c|c|c|}
\hline \multicolumn{5}{|c|}{$\begin{array}{c}\text { Montanha } \\
\text { Definição Verbal }\end{array}$} \\
\hline & Pré teste & Observações & Pós teste & Observações \\
\hline Juiz 1 & 3 & & 4 & Confunde montanha com morro \\
\hline Juiz 2 & 3 & & 3 & \\
\hline Juiz 3 & 3 & & 5 & \\
\hline Média & 3 & & 4 & \\
\hline
\end{tabular}

\begin{tabular}{lcccc}
\hline & & $\begin{array}{c}\text { Montanha } \\
\text { Desenho }\end{array}$ & \\
& Pré teste & Observações & Pós teste & Observações \\
\hline Juiz 1 & 3 & & 4 & \\
Juiz 2 & 3 & 3 & \\
Juiz 3 & 3 & 5 & \\
\hline Média & 3 & 4 & \\
\hline
\end{tabular}

\begin{tabular}{lcccc}
\hline & \multicolumn{4}{c}{$\begin{array}{c}\text { Árvore } \\
\text { Definição Verbal }\end{array}$} \\
& Pré teste & Observações & Pós teste & Observações \\
\hline Juiz 1 & 2 & & 4 & \\
Juiz 2 & 3 & & 3 & \\
Juiz 3 & 5 & & 5 & \\
\hline Média & 3,3 & & 4 & \\
\hline
\end{tabular}

\begin{tabular}{lcccc}
\hline & & $\begin{array}{c}\text { Árvore } \\
\text { Desenho }\end{array}$ & \\
& Pré teste & Observações & Pós teste & Observações \\
\hline Juiz 1 & 5 & & 5 & \\
Juiz 2 & 4 & 2 & \\
Juiz 3 & 5 & 3 & \\
\hline Média & 4,6 & 3,3 & \\
\hline
\end{tabular}


Trem

Definição Verbal

\begin{tabular}{lcccc} 
& Pré teste & Observações & Pós teste & Observações \\
\hline Juiz 1 & 4 & 5 \\
Juiz 2 & 3 & 3 \\
Juiz 3 & 5 & 5 & \\
\hline Média & 4 & 4,3 \\
\hline
\end{tabular}

\section{Trem}

Desenho

\begin{tabular}{lcccc} 
& Pré teste & Observações & Pós teste & Observações \\
\hline Juiz 1 & 4 & 5 & \\
Juiz 2 & 3 & 4 \\
Juiz 3 & 3 & & 5 & \\
\hline Média & 3,3 & 4,6 & \\
\hline
\end{tabular}

\begin{tabular}{lcccc}
\hline \multicolumn{5}{c}{ Leão } \\
& Definição Verbal & \\
& Pré teste & Observações & Pós teste & Observações \\
\hline Juiz 1 & 4 & 3 & \\
Juiz 2 & 3 & 4 & \\
Juiz 3 & 2 & 3 & \\
\hline Média & 3 & 3,3 & \\
\hline
\end{tabular}

Leão

Desenho

\begin{tabular}{lcccc} 
& Pré teste & Observações & Pós teste & Observações \\
\hline Juiz 1 & 5 & 4 \\
Juiz 2 & 3 & 3 & \\
Juiz 3 & 4 & 4 & \\
\hline Média & 4 & 3,6 & \\
\hline
\end{tabular}

\begin{tabular}{|c|c|c|c|c|}
\hline \multicolumn{5}{|c|}{$\begin{array}{c}\text { Prédio } \\
\text { Definição Verbal }\end{array}$} \\
\hline & Pré teste & Observações & Pós teste & Observações \\
\hline Juiz 1 & 4 & & 4 & \\
\hline Juiz 2 & 3 & & 3 & \\
\hline Juiz 3 & 5 & & 3 & \\
\hline Média & 4 & & 3,3 & \\
\hline
\end{tabular}




\begin{tabular}{lcccc}
\hline & & Prédio \\
& & & \\
& Desenho & & \\
& Pré teste & Observações & Pós teste & Observações \\
\hline Juiz 1 & 5 & & 4 & \\
Juiz 2 & 3 & 3 & \\
Juiz 3 & 5 & & 4 & \\
\hline Média & 4,3 & 3,6 & \\
\hline
\end{tabular}

\begin{tabular}{lcccc}
\hline & \multicolumn{4}{c}{$\begin{array}{c}\text { Ilha } \\
\text { Definição Verbal }\end{array}$} \\
& Pré teste & Observações & Pós teste & Observações \\
\hline Juiz 1 & 2 & & 4 & \\
Juiz 2 & 1 & 4 & \\
Juiz 3 & 1 & 5 & \\
\hline Média & 1,3 & 4,3 & \\
\hline
\end{tabular}

\begin{tabular}{lcccc}
\hline & & \multicolumn{2}{c}{$\begin{array}{c}\text { Ilha } \\
\text { Desenho }\end{array}$} \\
& Pré teste & Observações & Pós teste & Observações \\
\hline Juiz 1 & 3 & 5 & \\
Juiz 2 & 3 & 3 & \\
Juiz 3 & 3 & 2 & \\
\hline Média & 3 & 3,3 & \\
\hline
\end{tabular}

Sujeito: Fábio (17 anos)

Girafa

Definição Verbal

\begin{tabular}{|c|c|c|c|c|}
\hline & Pré teste & Observações & Pós teste & Observações \\
\hline Juiz 1 & 5 & & 5 & \\
\hline Juiz 2 & 3 & & 4 & \\
\hline Juiz 3 & 2 & & 4 & \\
\hline Média & 3,3 & & 4,3 & \\
\hline
\end{tabular}




\begin{tabular}{lcccc}
\hline & \multicolumn{4}{c}{$\begin{array}{c}\text { Girafa } \\
\text { Desenho }\end{array}$} \\
& Pré teste & Observações & Pós teste & Observações \\
\hline Juiz 1 & 5 & & 5 & \\
Juiz 2 & 1 & 2 & \\
Juiz 3 & 1 & 3 & \\
\hline Média & 2,3 & 3,3 & \\
\hline
\end{tabular}

\section{Nuvem}

Definição Verbal

\begin{tabular}{lcccc} 
& Pré teste & Observações & Pós teste & Observações \\
\hline Juiz 1 & 5 & 5 & \\
Juiz 2 & 3 & 4 & \\
Juiz 3 & 5 & 5 & 4,6 \\
\hline Média & 4,3 & & \\
\hline
\end{tabular}

Nuvem

Desenho

\begin{tabular}{lcccc} 
& Pré teste & Observações & Pós teste & Observações \\
\hline Juiz 1 & 5 & 3 & \\
Juiz 2 & 3 & & 3 & \\
Juiz 3 & 5 & 1 & \\
\hline Média & 4,3 & 2,3 & \\
\hline
\end{tabular}

\begin{tabular}{lccc}
\hline & \multicolumn{4}{c}{$\begin{array}{c}\text { Montanha } \\
\text { Definição Verbal } \\
\end{array}$} & Pré teste & Observações & Pós teste & Observações \\
\hline Juiz 1 & 5 & 5 & \\
Juiz 2 & 5 & 4 & \\
Juiz 3 & 5 & 3 & \\
\hline Média & 5 & 4 & 5 \\
\hline
\end{tabular}

Montanha

Desenho

\begin{tabular}{|c|c|c|c|c|}
\hline & Pré teste & Observações & Pós teste & Observações \\
\hline Juiz 1 & 5 & & 4 & \\
\hline Juiz 2 & 5 & & 3 & \\
\hline Juiz 3 & 5 & & 3 & \\
\hline Média & 5 & & 3,3 & \\
\hline
\end{tabular}




\begin{tabular}{|c|c|c|c|c|}
\hline \multicolumn{5}{|c|}{$\begin{array}{c}\text { Árvore } \\
\text { Definição Verbal }\end{array}$} \\
\hline & Pré teste & Observações & Pós teste & Observações \\
\hline Juiz 1 & 5 & & 5 & \\
\hline Juiz 2 & 3 & & 5 & \\
\hline Juiz 3 & 5 & & 5 & \\
\hline Média & 4,3 & & 5 & \\
\hline
\end{tabular}

\begin{tabular}{lcccc}
\hline & & $\begin{array}{c}\text { Árvore } \\
\text { Desenho }\end{array}$ & \\
& Pré teste & Observações & Pós teste & Observações \\
\hline Juiz 1 & 5 & & 2 & \\
Juiz 2 & 2 & 3 & \\
Juiz 3 & 3 & & 2 & \\
\hline Média & 3,3 & 2,3 & \\
\hline
\end{tabular}

\begin{tabular}{|c|c|c|c|c|}
\hline \multicolumn{5}{|c|}{$\begin{array}{c}\text { Trem } \\
\text { Definição Verbal }\end{array}$} \\
\hline & Pré teste & Observações & Pós teste & Observações \\
\hline Juiz 1 & 5 & & 5 & \\
\hline Juiz 2 & 4 & & 4 & \\
\hline Juiz 3 & 5 & & 5 & \\
\hline Média & 4,6 & & 4,6 & \\
\hline
\end{tabular}

\begin{tabular}{lcccc}
\hline & & $\begin{array}{c}\text { Trem } \\
\text { Desenho } \\
\end{array}$ & & \\
& Pré teste & Observações & Pós teste & Observações \\
\hline Juiz 1 & 5 & & 5 & \\
Juiz 2 & 3 & 3 & \\
Juiz 3 & 3 & & 4 & \\
\hline Média & 3,6 & 4 & \\
\hline
\end{tabular}

Leão

Definição Verbal

\begin{tabular}{lcccc} 
& Pré teste & Observações & Pós teste & Observações \\
\hline Juiz 1 & 4 & 5 & \\
Juiz 2 & 3 & 4 & \\
Juiz 3 & 3 & 5 & \\
\hline Média & 3,3 & 4,6 & \\
\hline
\end{tabular}




\begin{tabular}{lcccc}
\hline & \multicolumn{1}{c}{$\begin{array}{c}\text { Leão } \\
\text { Desenho } \\
\text { Observações }\end{array}$} & Pós teste & Observações \\
\hline Juiz 1 & Pré teste & & 5 & \\
Juiz 2 & 1 & 4 & \\
Juiz 3 & 2 & 3 & \\
\hline Média & 1 & & 4 & \\
\hline
\end{tabular}

\begin{tabular}{lcccc}
\hline \multicolumn{5}{c}{$\begin{array}{c}\text { Prédio } \\
\text { Definição Verbal }\end{array}$} \\
& Pré teste & Observações & Pós teste & Observações \\
\hline Juiz 1 & 4 & Confunde prédio e apartamento & 5 & \\
Juiz 2 & 3 & & 3 & \\
Juiz 3 & 4 & & 4 & \\
\hline Média & 3,6 & & 4 \\
\hline
\end{tabular}

\begin{tabular}{|c|c|c|c|c|}
\hline \multicolumn{5}{|c|}{$\begin{array}{c}\text { Prédio } \\
\text { Desenho }\end{array}$} \\
\hline & Pré teste & Observações & Pós teste & Observações \\
\hline Juiz 1 & 5 & & 3 & \\
\hline Juiz 2 & 4 & & 3 & \\
\hline Juiz 3 & 5 & & 2 & \\
\hline Média & 4,6 & & 2,6 & \\
\hline
\end{tabular}

\begin{tabular}{|c|c|c|c|c|}
\hline \multicolumn{5}{|c|}{$\begin{array}{c}\text { Ilha } \\
\text { Definição Verbal }\end{array}$} \\
\hline & Pré teste & Observações & Pós teste & Observações \\
\hline Juiz 1 & 5 & & 5 & \\
\hline Juiz 2 & 4 & & 4 & \\
\hline Juiz 3 & 5 & & 5 & \\
\hline Média & 4,6 & & 4,6 & \\
\hline
\end{tabular}

\begin{tabular}{lcccc}
\hline & \multicolumn{2}{c}{$\begin{array}{c}\text { Ilha } \\
\text { Desenho }\end{array}$} \\
& Pré teste & Observações & Pós teste & Observações \\
\hline Juiz 1 & 5 & 5 & \\
Juiz 2 & 5 & 5 & \\
Juiz 3 & 5 & 5 & 5 \\
\hline Média & 5 & & 5 & \\
\hline
\end{tabular}

